\title{
WestVirginiaUniversity
}

THE RESEARCH REPOSITORY @ WVU

Graduate Theses, Dissertations, and Problem Reports

2018

\section{Britishers in Two Worlds: Maltese Immigrants in Detroit and Toronto, 1919-1960}

\author{
Marc Anthony Sanko
}

Follow this and additional works at: https://researchrepository.wvu.edu/etd

\section{Recommended Citation}

Sanko, Marc Anthony, "Britishers in Two Worlds: Maltese Immigrants in Detroit and Toronto, 1919-1960" (2018). Graduate Theses, Dissertations, and Problem Reports. 6565.

https://researchrepository.wvu.edu/etd/6565

This Dissertation is protected by copyright and/or related rights. It has been brought to you by the The Research Repository @ WVU with permission from the rights-holder(s). You are free to use this Dissertation in any way that is permitted by the copyright and related rights legislation that applies to your use. For other uses you must obtain permission from the rights-holder(s) directly, unless additional rights are indicated by a Creative Commons license in the record and/ or on the work itself. This Dissertation has been accepted for inclusion in WVU Graduate Theses, Dissertations, and Problem Reports collection by an authorized administrator of The Research Repository @ WVU.

For more information, please contact researchrepository@mail.wvu.edu. 


\title{
Britishers in Two Worlds: Maltese Immigrants in Detroit and Toronto, 1919-1960
}

\author{
Marc Anthony Sanko \\ Dissertation submitted \\ to the Eberly College of Arts and Sciences \\ at West Virginia University
}

in partial fulfillment of the requirements for the degree of

Doctor of Philosophy in

History
Kenneth Fones-Wolf, Ph.D., Chair
James Siekmeier, Ph.D.
Joseph Hodge, Ph.D.
Melissa Bingmann, Ph.D.
Mary Durfee, Ph.D.

Department of History
Morgantown, West Virginia
2018

Keywords: Immigration History, U.S. History, Canadian History, British History, Diplomatic History, Transnational History

Copyright 2018 Marc Anthony Sanko 


\title{
ABSTRACT \\ Britishers in Two Worlds: Maltese Immigrants in Detroit and Toronto, 1919- 1960
}

\author{
Marc Anthony Sanko
}

This dissertation looks at the immigration of Maltese laborers and their families to North America, chiefly Detroit and Toronto, between 1919 and 1960. While the Maltese migration followed similar patterns to other Southern European Catholic or skilled laborers in general, it is different in both their timing and colonial association. Most migrants came to North America in the late $19^{\text {th }}$ and early $20^{\text {th }}$ century, but the Maltese migration occurs largely after World War I and extends through the 1960s - the exact time frame of immigration restrictions imposed by both the governments of the United States and Canada. How the Maltese immigrants were able to skirt these legal restrictions comes down to their imperial standing as part of the British Empire and the skilled trades that many migrants brought with them. Therefore, this dissertation attempts to be both a comparative study of immigration policy and foreign policy between the United States, Canada, and Great Britain, as well as a transnational study of a migrant group that spans not just the transatlantic world but also the North American border. 
Dedicated to my grandmother, Rose Mifsud.

The family stories she tells with such a joy in her heart inspired me to pursue a degree in history, so I could understand the world she so vividly describes. 


\section{Acknowledgments}

A work of this magnitude is not complete without help from countless individuals in our life, and it is my pleasure to acknowledge those individuals here. My gratitude is immense for all who have helped me on my path. First to the countless archivists from around the world, without whose kindness and aid this dissertation would be sorely lacking. While there have been staff changes at several places, I specifically want to mention the West Junction Historical Society in Toronto for opening their doors late one hot summer afternoon for a traveling scholar and the staff at the Staffordshire Archives in England who prepared the diary of Sir Walter Congreve. The diary was interesting and helpful, but the conversation with the archivists at the end of the day covered a wide range of topics from comparisons of the Midlands to the Midwest, and the rise of populist politicians, to even just talk of sports. It was a joy for someone who loves good conversation with good people. Finally, a million thanks extended to Steven Wejroch, the fountain of knowledge at the Archdiocese of Detroit Archives. The Maltese may not have been the biggest parish, and I enjoyed your conversations about some of the rowdier parishes, but you gave me more support than I could have ever hoped for.

For all those academic influences on my life that led to this point, I am forever grateful to you. From AP History teachers in High School, to interesting classes taught by brilliant minds at University of Michigan - Dearborn and Michigan Technological University that helped me shape my intellectual pursuits. Specifically, Mary Durfee who not only mentored me for a short time at Michigan Tech, but has been a great supporter of my Maltese research and has remained a good friend for all these years. I know she is enjoying her retirement, and I was honored to have her on this committee.

For the faculty at Edinboro University, particularly my committee members who pushed me to think outside of the Catholic Church connection with the Maltese when I went on for a 
$\mathrm{PhD}$. Two individuals specifically I want to mention from Edinboro, the first being Jerra Jenrette, my committee chair and advisor for my Master's degree. Jerra has been a wonderful supporter through the whole process. I cherish our friendship and her support in all my academic pursuits. Also on a more somber note, Joe Laythe, who sadly passed from this life in 2016. Diagnosed with cancer at the end of my time at Edinboro, he never once lost his incredible sense of humor, his intellectual tact, or his demanding of students to search for truth and goodness in the world. Laythe also undoubtedly shaped my teaching approaches. I have never seen a man so invested in his students physical and mental well-being and growth. The connections he made with every single student in every single class he taught continues to astound me to this day. Even as he battled his cancer he continued to give energetic, fun, and intellectually challenging lectures that captured students in a way I can only strive to imitate. Joey, you are certainly missed. But don't worry, "it’s all good" here.

My thanks extend to my current committee and those who helped me along the way here at West Virginia University in the Department of History. In five years in Morgantown I have grown not just as a person but absolutely as an academic. That wouldn't have been possible without the guidance of the whole faculty, but specifically folks who both challenged and aided me early on in the research stage of my dissertation. Without the likes of Jim Siekmeier or Joe Hodge I would have spent hours - if not days - of valuable research time simply attempting to figure out how to navigate the vast collections of the National Archives in the US and the UK. Of course, their expertise in Diplomatic History and British History kept me on my toes while writing this dissertation. Professionally as well I must thank Melissa Bingmann. This dissertation not only worked as traditional academic piece but has transcended to several different public history projects. Being able to bounce ideas off one another over the past five years - from grant 
applications, to digital history components, and beyond - has been tremendously helpful. I'm happy to count them all as colleagues and friends today.

This dissertation would be a jumbled mess without the guidance of Ken Fones-Wolf. Not only has Ken greatly shaped the way I've looked at these sources and the arguments I've made, but he has forced me to be a better, more succinct and impactful writer. Wherever you find my argument is clear and concise, you can thank Ken. If you find it still wanders too much, I could take the credit for that failure, or you can blame Ken for not finding my mistakes. I leave that choice to you. I'm sorry Ken, I have been long-winded since the day I began talking but I'm working on it. I also want to thank Ken for his friendship, not only to myself but also to my wife Amanda. It makes a tremendous difference to know your advisor is in your corner both academically and personally. As a family, we have really enjoyed our years in Morgantown and Ken has played a large part in that.

Speaking of our time in West Virginia, I also have to give a big written hug to all of those individuals we have met here, many of whom have become close and cherished friends. To the folks of my cohort, those above and behind me in the Ph.D. program especially Justin Power, Luke Gramith, Charles Welsko, Zac Cowsert, Kenny Kolander, Greg Michna, Tyler Krahe, Lacey Bonar, Alex Burns, and Cole Volman. I want to thank you all for the great - and late nights having drinks chatting about work or life and beyond. Those venting sessions often turned into impromptu roundtables about our shared topics or about potential avenues for our works. Thus, thanks go out hand-in-hand with all the significant others who also hung around and listened to us talk incessantly about history. We appreciate you sticking with us.

To my family. I was blessed to grow up so close to extended family, particularly my Aunt Madalyn and grandparents John and Rose Mifsud. Having sleep overs with our cousin, Austin 
Mifsud, at grandma's house was the pinnacle of childhood fun and made a brother out of a cousin. Of course, it was at grandma's that my passion for history bloomed. Late nights watching World War II movies blended with family histories told with such passion and joy that I couldn't help but be captivated. I'm so glad I had the opportunity to capture some of those stories here. To my brother, Sean, we may have enjoyed typical sibling rivalry growing up, but you should know that I always have always been your biggest supporter and admire your passion to succeed at anything and everything you do. You've become one heck of a teacher and a coach to kids who really need a strong mentor in their lives. I'm proud of you little brother.

I am also forever in debt to my mother who, with two boys to raise, went back to work multiple jobs after my father passed at an early age. She made sure my brother and I had every opportunity to succeed in life. Amazingly, even though both of her sons participated in sports, band, and seemingly a hundred other activities through middle and high school, she never missed a single one of our events that I can recall. How she did it all I will never know. But she has been an inspiration in my life and the definition of a strong woman. Without her sacrifices and dedication to our futures, neither my brother or I would be half as successful as we are today.

Finally, to my dear wife Amanda. There is honestly not a single word or set of words that I can write to express how much you mean to me. Cheesy and cliché, yes but it is true. You, perhaps foolishly, took a leap of faith and moved to West Virginia to pursue a still budding relationship with a weird guy from Michigan who couldn't shut up about the Maltese and history. And as they say the rest is history. Your faith in me and my work has never shaken, and you forced me to continue to see the bright side of things even when the research and writing was most frustrating. Perhaps most importantly, you kept me grounded to the real non-academic world. While this might be my life, it is also my job. Mimicking your work schedule helped to 
keep the insanity at bay and give us a "normal" life. I could continue for an entire chapter, so it is best to practice brevity here. Amanda, I adore you and I can never thank you enough for all your patience and love. 


\section{Table of Contents}

Chapter 1 - A Maltese Saga in a New World .......................................................................................... 1

Chapter 2 - Malta in the British World......................................................................................... 12

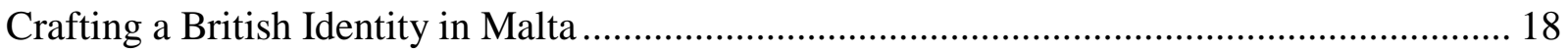

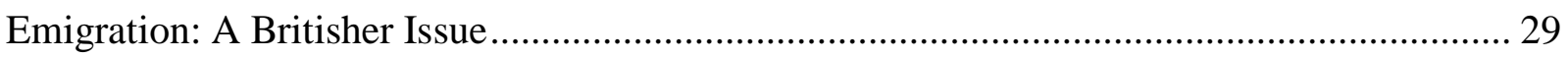

Chapter 3 - Shutting North America's Doors....................................................................................... 40

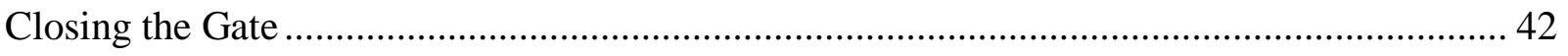

The Continental Market for Labor …………………………………………………....... 53

Chapter 4 - Maltese in Canada ......................................................................................................... 69

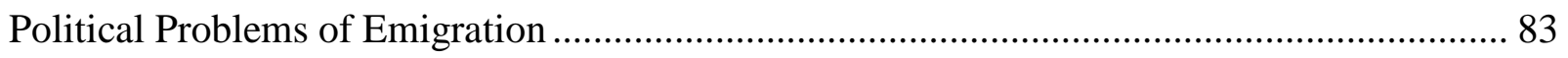

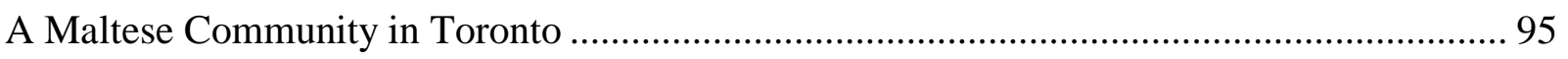

Chapter 5 - Maltese in Detroit .......................................................................................... 113

Economic Need and the Political Will for Detroit ............................................................... 119

Social Development in Detroit ..................................................................................... 136

Chapter 6 - Community Challenges: Depression and a World War........................................ 151

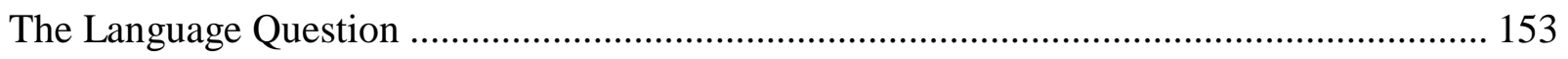

The Great Depression in Detroit and Toronto .................................................................. 158

Community Organization and the Catholic Church ........................................................... 166

World War II, the Great Unifier......................................................................................... 175

Chapter 7 - Imperial Change in a Postwar Decade......................................................................... 187

Postwar Malta and its status within the Empire ................................................................ 187

Chapter 8 - The Struggles of Post-War Communities.................................................................... 206

A Changing North America ............................................................................................... 207

Changes within the Maltese Communities............................................................................ 218

Epilogue: How Have the Communities Changed? ........................................................................... 244

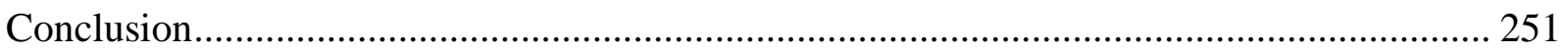

Appendix A - Bibliography .......................................................................................................... 255 


\section{Chapter 1 - A Maltese Saga in a New World}

A wave of anti-immigration sentiment has swept the western world over the course of just a few years. Politicians and national immigration policy in these countries are being challenged by their constituents and their political opponents to develop new policies towards immigration. ${ }^{1}$ These pressures are driving wellsprings of nativist fears, and have given rise to political actors like Donald Trump in the United States and Nigel Farage in the United Kingdom, among a host of other anti-immigration politicians. These politicians have struck a chord with nativist sentiment, often touting that a nation is only a nation when there is strict border control. In the United States, this political bluster combined with Trump's promises to "build a wall" along the U.S. - Mexican border, and his promises to rework American immigration law catapulted his campaign to a surprising electoral victory. ${ }^{2}$ Nigel Farage's "Brexit" campaign foreshadowed the success of Donald Trump, playing on British fears of unchecked immigration and falling wages as part of their association with the European Union, arguing that a vote to leave the EU would secure British borders. At a time of increasing refugee movement into Europe, the British voters did in fact chose to leave the EU. ${ }^{3}$ These reactions are not surprising. As industrialized economies shift to accommodate increasing globalization and movement

\footnotetext{
${ }^{1}$ Particularly in the United States, rightwing anti-immigration political actors are even challenging established Republicans who they deem "too weak" on immigration and border security. As the 2018 Mid-term elections approach, several incumbent Republicans are facing challenges from both Democrat candidates and rightwing, populist primary challengers from within the Republican party. Jonathan Martin, "Dean Heller's Party Loyalty Not Enough to Stop a G.O.P. Primary Challenge in Nevada," The New York Times, 8 August 2017. https://www.nytimes.com/2017/08/08/us/politics/dean-heller-nevada-republicans-danny-tarkanian.html

${ }^{2}$ As of February 23, 2018, the United States Citizenship and Immigration Services changed its mission statement to more accurately reflect its current directives. The new mission statement scrubs the mention of the United States being a nation of immigrants, rather stating that the Service “administers the nation's lawful immigration system..." This change is indicative of growing nativist sentiment in the United States. Kim Hjelmgaard and Alan Gomez, "America is no longer a 'nation of immigrants'," USA Today, 23 February 2018. https://www.usatoday.com/story/news/world/2018/02/23/america-no-longer-nation-immigrants-uscissays/366207002/

3 "EU referendum: Nigel Farage tells Leave campaigners to focus on migration," $B B C N e w s-E U$ Referendum, 29 April 2016. http://www.bbc.com/news/uk-politics-eu-referendum-36167329
} 
between nations has become easier, immigrants have yet again become scapegoats for the economic troubles of the average worker.

Despite recent political bluster and fears of immigration, for centuries mass migration and the accompanying political backlash - has been the status quo of global affairs. In North America, this movement began as early as the first European colonies were founded. The movement of people to North America only accelerated through the centuries, as millions of Europeans, Africans, and Asians came to this continent, some willingly, others enslaved or indentured. This movement of people routinely faced a political and social backlash by those previously established individuals and societies. In the United States and Canada, intense nativist reactions to the migration of Irish, Chinese, and German laborers in the early and middle $19^{\text {th }}$ Century sparked some of the first anti-immigration legislation. In the 1880s, both the United States and Canada crafted immigration policy that excluded migrants from China and as the decades wore on, nearly all Asian migrants found entry restricted. ${ }^{4}$ These legislative policies clamped down on Asian migration at the exact moment migration blossomed from Southern and Eastern Europe. The flood of Italians, Poles, Russians, Greeks and others also faced opposition. In the aftermath of World War I, anti-immigration fervor sparked legislation that closed doors across the world, erecting a "Great White Wall" around the United States, Canada, and Australia. $^{5}$

\footnotetext{
${ }^{4}$ For works on Asian migration specifically see; Erika Lee and Judy Yung, Angel Island: Immigrant Gateway to America (New York: Oxford University Press, 2010), Erika Lee, At America's Gates: Chinese Immigration During the Exclusion Era, 1882-1943 (Chapel Hill: University of North Carolina Press, 2005).

${ }^{5}$ For more on nativism, race and ethnicity, and immigration policy see; John Higham, Strangers in the Land: Patterns of American Nativism, 1860-1925 (New Brunswick, NJ: Rutgers University Press, 1955), Desmond King, Making Americans: Immigration, Race, and the Origins of the Diverse Democracy (Cambridge: Harvard University Press, 2000), Roger Daniels, Not Like Us: Immigrants and Minorities in America, 1890-1924 (Chicago: Ivan R. Dee Press, 1997).
} 
Just after these major immigration stories of the late $19^{\text {th }}$ and early $20^{\text {th }}$ Century sits the Maltese migrant experience. Due to their insignificant numbers compared to other migrant communities, the Maltese story is one that remains largely invisible in the overall narrative of immigration to North America. Not only is the Maltese community small, but their story fails to significantly alter the narrative because on the surface it mimics other, much larger, Southern European migrant stories. Much like neighboring Italian migrants, the Maltese faced social and racial discrimination upon arriving in North America. ${ }^{6}$ Also, like their counterparts migrating from Europe, they generally left their home for economic reasons. The idea of America as a land of plenty with considerable economic opportunity coursed through the conversations in Malta just as they did across the rest of the continent.

The Maltese story is not just hidden beneath that of their fellow Southern Europeans, but also subsumed by a broader Catholic migration history. Starting in the $19^{\text {th }}$ Century, Catholics began to migrate in large numbers to the United States and Canada. This migration rocked the religious make-up of North America, and in attempting to understand how those people built their religious and social communities, scholars have focused on the major groups of migrants Italians, Poles, Belgians, and Irish. ${ }^{7}$ While the Maltese exhibited strong parish identification, crafting a "Maltese" ethnic parish in both Detroit and Toronto, so too did other Catholic

\footnotetext{
${ }^{6}$ On issues of racial discrimination and "whiteness" see; Thomas A Guglielmo, White on Arrival: Italians, Race, Color, and Power in Chicago, 18901945 (New York: Oxford University Press, 2004). John Hartigan, Racial Situations: Class Predicaments of Whiteness in Detroit (Princeton: University of Princeton Press, 1999). David Roediger, Working Toward Whiteness: How America's Immigrants Became White: The Strange Journey from Ellis Island to the Suburbs (New York: Basic Books, 2005), David Roediger and Elizabeth D. Esch. The Production of Difference: Race and Management of Labor in U.S. History (New York: Oxford University Press, 2012).

${ }^{7}$ For works on Catholic and ethnic identity in immigrant communities see; Gary Gerstle, Working-Class Americanism: The Politics of Labor in a Textile City, 1914-1960 (New York: Cambridge University Press, 1989); June Alexander, The Immigrant Church and Community: Pittsburgh's Slovak Catholics and Lutherans, 1880-1915 (Pittsburgh: University of Pittsburgh Press, 1987); David Richards, Italian American: The Racializing of an Ethnic Identity (New York: New York University Press, 1999); Gary Ross Mormino, Immigrants on the Hill: ItalianAmericans in St. Louis 1882-1982 (Urbana: University of Illinois Press, 1986).
} 
communities. Often these larger ethnic parishes occupied prominent buildings and produced a vocal and civically engaged congregation. ${ }^{8}$ Once again, these groups dwarfed the Maltese.

Looking broadly at the migration experience of the $19^{\text {th }}$ and $20^{\text {th }}$ Century, the Maltese experience captures the transnational nature and international diaspora characteristics that resemble other ethnic groups. Thousands of migrants who came to North American over the century did so on a temporary basis, searching out employment on the continent while returning to their native homelands after a period. Others made a more seasonal journey. In a world more easily connected with increasingly quick and affordable transoceanic travel, the opportunity to work in one nation and return eventually or seasonally to the "old world" became far easier. Regardless, these back and forth movements of migrants created conduits through which information flowed, seemingly closing the distance between communities and building truly transnational communities. Again, the Maltese fit nicely into that story line as they moved back and forth across the Atlantic and between the United States and Canada. ${ }^{9}$

Despite all these similarities with competing migrations, the Maltese experience defies some of the tropes of the Southern European, Catholic story. These differences make the Maltese story worthy of deeper inspection. Perhaps the most jarring of factors is the timing of the migration. While most Southern European migration occurs during the late $19^{\text {th }}$ and early $20^{\text {th }}$ Century, and is the chief reason for the exclusionary policies in the post-war era, the Maltese do

\footnotetext{
${ }^{8}$ On the history of the Archdiocese of Detroit and its ethnic congregations see; Leslie Woodcock Tentler, Seasons of Grace: A History of the Catholic Archdiocese of Detroit (Detroit: Wayne State University Press, 1990).

${ }^{9}$ For works discussing transnational communities see; Walter Nugent, Crossings: The Great Transatlantic Migrations, 1870-1914 (Bloomington: Indiana University Press, 1992); Gunther Peck, Reinventing Free Labor: Padrones and Immigrant Workers in the North American West, 1880-1930 (Cambridge: Cambridge University Press, 2000); Peggy Levitt, The Transnational Villagers (Berkeley: University of California Press, 2001); Teresa Fava Thomas, The Reluctant Migrants: Migration from the Italian Veneto to Central Massachusetts (Amherst, New York: Teneo Press, 2015).

For works on the transnational aspect of the Great Lakes see; John Bukowczyk, Nora Faires, David R. Smith, and Randy Williams Widdis, Permeable Border: The Great Lakes Basin as Transnational Region, 16501990 (Pittsburgh: University of Pittsburgh Press, 2005).
} 
not begin to come to North America in considerable numbers until after World War I. Though small, that migration pattern continued throughout the middle part of the century, slowing only in the 1960s and early 1970 s - the same time immigration laws loosened in both the United States and Canada. Therefore, the overwhelming majority of the Maltese migration experience occurs during the era of exclusion, just the opposite of their Southern European counterparts.

The Maltese story also adds nuance to immigration narratives by adding a complicating colonial factor unlike other European migrants. The British rule of Malta, at least for those intending migrants, brought many advantages and a small number of surprising setbacks. Regardless, their claim to British-ness changed the equation for Maltese migrants as they sought new places of work and new homes in North America. Malta's position in the center of the Mediterranean brought with it heavy investment by London to bring the significant port and its people up to a more modern and British standard. Thus, a significant portion of Maltese laborers had the opportunity to learn industrial skills that set them apart once in North America. Beyond the technical training, Maltese society grew accustomed to operating in tandem with British society. Learning passable English and being able to accommodate English society while retaining Maltese identity prepared them for life in other nations. Arriving in the Anglodominated North American nations, their ability to swap an English culture with an American or Canadian culture happened with relative ease, despite their miniscule numbers. Thus colonialism, for those intending migrants, reflected a "Gift of Empire" that served as a "dress rehearsal for emigration." 10 The success of Maltese migrants once in North America proved this to be true.

\footnotetext{
${ }^{10}$ Joseph Lubig writes the term "dress rehearsal for emigration," in his work Maltese in Michigan, but the additional meaning attached to a "Gift of Empire" is one that I believe more fully encompasses the reality. While all of Maltese history may have been a prominently colonial past, it is the British influence in the $19^{\text {th }}$ and $20^{\text {th }}$ Century
} 
Added to these caveats that make the Maltese story worth exploration is an international diplomacy web that pulled strings overhead, using imperial policy to pry open doors to the U.S. and negotiate immigration to Canada. While there are many examples of the intersection of foreign policy and immigration policy, the Maltese case shows how both a sense of "Britishness" on a social level was complemented by a British desire to achieve imperial goals by moving Maltese people to other locations within the Empire and the United States. ${ }^{11}$ The negotiations between governments offer an interesting comparison and illuminates the differences in immigration policy between the United States and Canada. What is often thought of as a unified "White Wall" of exclusionary policy in the middle $20^{\text {th }}$ Century is not so solid after all. At the very least, the reasons for deciding who can and cannot enter each nation were formulated under different pressures. ${ }^{12}$

Finally, the Maltese story is one that builds from recent scholarship asking similar questions about the intersection of the search for work and imperial diplomacy. Julie Greene's recent article, "Builders of Empire: Rewriting the Labor and Working-Class History of AngloAmerican Global Power," calls attention to labor history within imperial settings. Greene argues that, "Transnational methodologies are based on the premise that the history of a nation-state can never be contained successfully by static territorial boundaries... Since nation-states in the modern era have been connected to powerful expansionist forces such as imperialism, colonialism, and capitalism, it is not surprising that the historical discipline has become reoriented to examine in more sophisticated ways the connections between nations and the wider

\footnotetext{
that endows the Maltese migrant with some ability to succeed in the Anglo world. Joseph Lubig, Maltese in Michigan (East Lansing: Michigan State University Press, 2011).

${ }^{11}$ For another work on British identity in migrants see; Cindy Hahamovitch, No Man's Land: Jamaican Guestworkers in America and the Global History of Deportable Labor (Princeton: Princeton University Press, 2011).

12 Donna Gabaccia, Foreign Relations: American Immigration in Global Prospective (Princeton: Princeton University Press, 2012).
} 
world." 13 Greene offers a methodology for this approach writing, "A bottom-up history of the US and British empires does not require neglecting the strategies of elite officials but instead helps us better understand their policies and perspectives." For example, Greene suggests that U.S. officials "had to articulate their goals, devise new ways of managing labor, and confront new tensions between colonial subjecthood and the rights of citizens or between the demands of successful occupation and the hopes and expectations of workers. [emphasis added]"14

Ultimately the depth of the Maltese story allows this dissertation to engage with both a social and transnational history alongside an intriguing comparative and diplomatic history. The transnational story of an interesting diaspora on a social level stretches across the Atlantic as Maltese immigrants, like their counterparts from around the globe, kept in close communication with their native homelands. Added to this transatlantic tie is an intimate connection between the community in Detroit and its partner community in Toronto. The smallness of the Maltese migration meant that the two communities were often linked by more than just a common ethnicity, but generally by blood with brothers and sisters, or at the very least close cousins, living in one of the two communities. The proximity of Detroit and Toronto allowed them not only to keep in contact but also to share resources and build a transnational community on the North American continent. The diplomatic history, however, reveals nuances in how the United States and Canada built their immigration policy during the exclusionary era. While the United States was willing to let Britain decide the Maltese fate, and under which quota they should be admitted, the Canadians were not so flexible. In fact, the Maltese case highlights a growing push

${ }^{13}$ Julie Greene, "Builders of Empire: Rewriting the Labor and Working-Class History of Anglo-American Global Power," Labor - Studies in Working-Class History of the Americas, 13, no. 3-4 (December 2016): 2. Greene is an influential scholar on the intersection of foreign policy and immigration policy, particularly looking at the American Empire and the way in which policy coerced labor.

${ }^{14}$ Ibid., 3. 
in Ottawa for independence in terms of foreign policy that echoed around the Dominions in the early $20^{\text {th }}$ Century. The Maltese exclusion from Canada was built on Ottawa's insistence on their own ability to identify who was and was not British.

This work tackles these complicated and intriguing questions of Maltese migration by viewing a roughly forty-year period between 1919 and 1960. By examining this time frame, I intend to capture the bulk of migration to North America from Malta. Invariably, Maltese individuals migrated to continent both before 1919 and after 1960, but those individuals were part of a small trickle rather than a comparative flood that occurs during this span. The dissertation begins in chapter two by detailing the Maltese experience as a British Colony prior to the push for immigration. This chapter will provide context for the rest of the work, laying out the factors that caused immigration to become a necessary step. Understanding this relationship forms a critical argument for the rest of the dissertation, claiming that retention of British norms, including the English language and modern industrial work established within Malta forms a cornerstone for their success abroad. Not only will it explore the intermingling of Maltese and British culture, but it aims to show the political wrangling necessary to bring the Maltese into the British realm. It will explore the lives of the Maltese who later became emigrants, how they interacted with both the Anglo and the Maltese world, and what skills or industrial work experience they may have acquired that would prove useful in their journey.

The third chapter moves to North America, exploring the developments in post-war America and Canada regarding immigration law and tendencies. In this chapter, the intersection of diplomacy and immigration play out as British Imperial might opened doors and influenced North American immigration law, therefore allowing the Maltese access to a market otherwise closed. It further explores how the British acted on the behalf of the Maltese, and in turn what 
forces contributed to both Canada and the United States bending, or not bending, to accommodate British and Maltese requests. The chapter finds nuance in the political back and forth between the Canadians and the British, highlighting the growing push for greater independence from their colonial masters in London. The Maltese immigrants became pawns in a global political feud. Finally, it answers why the migrants from Malta originally chose to settle primarily in Detroit over various other American and Canadian cities.

Beginning with the fourth chapter the dissertation briefly splits the story into a chapter on the founding of the Toronto community and a later chapter on the founding of the Detroit community. Chapter four brings the narrative to Toronto during the interwar era. The chapter wrestles with slightly different questions than the chapter on Detroit. First and foremost, it has to show why individuals chose to stay in Toronto rather than "direct[ing] their steps to Detroit" as Maltese immigration reports in the early 1920 s recommended. ${ }^{15}$ It will also explore the establishment of community clubs, newspapers, radio stations, bakeries, and churches to find if they occurred at a similar rate to that of the community in Detroit and the pace at which the community established itself in comparison with other ethnic groups in Toronto. Questions include: why did these individuals decide to spurn the economic draw of Detroit to remain in Toronto, and what benefits were there for Maltese in Toronto that may not have been present in Detroit? This chapter, then, helps illuminate the differences and/or similarities between the United States and Canadian immigration histories.

Once in Detroit, the fifth chapter explains how settlement within the city's Corktown district was unique. How was it that a community of only two or maybe three thousand

\footnotetext{
15 Joseph Howard, Report on Emigration, 1918-1920. Malta: Department of Emigration, 21 May 1920, Document attached to Consul Carl R. Loop to Malta to the Department of State, 24 May 1920, 849B.5611/2, RG 59, Records of the Department of State, NARA II, College Park, MD, p. 6, sec. 6-7.
} 
immigrants were able to construct a cultural niche in the neighborhood within a matter of a half decade? The first immigrants from Malta began to populate Detroit in 1919 and by 1922 cultural mediums like ethnic newspapers, radio shows, church services, social clubs, and restaurants or bakeries had been established in the community. While these types of cultural mediums were not unique in the immigrant experience, what is unique is the rate at which the Maltese were able to accomplish these tasks. Considering the miniscule numbers of Maltese in comparison to other ethnicities across the city, this requires some deeper consideration.

Chapter six then moves the narrative into the era of the Depression and World War II. It explores how imperial politics continued to impact Malta and its position within the global community. In North America, it takes a nuanced look as to how the communities in Detroit and Toronto adapted to their new home cities and how they were able to survive through the grips of the Great Depression. The era of the Great Depression and World War II exhibit how the Maltese were able to both involve themselves in their local communities, following through with the processes of integration and citizenship while still staying in touch with their native Malta. The devastation that Malta encountered during the war brought the communities together for fundraising and highlighted just how invested both were in their homelands. Chapter seven shifts to an uncertain post-war world. As Malta emerged from the devastation of war, growing political issues over Malta's place within the empire boiled over. Maltese identity as Britishers, so crucial to their success as migrants, became a major bone of contention between a Maltese government bent on more autonomy and a British government desiring to keep the status quo. Ultimately, after a failed flirtation with a tighter political union between Malta and the United Kingdom, total independence emerged as the only answer to Malta's political question. But these 
machinations of politicians hindered the Maltese ability to migrate unencumbered across the globe.

Chapter eight explores how the communities of North America dealt with declining numbers of Maltese immigrants and yet continued to grow their communities. However, these communities mirrored other ethnic groups in their host cities. Those in Detroit fled for the suburbs and scattered the community while those in Toronto grew with a burst of new immigration centered directly in the city. These changes drastically reshaped the Maltese communities in Detroit and in Toronto. Even with the communities experiencing great shifts in the physical location of their compatriots, the institutions created in the 1920 s and beyond continued to service those Maltese. Finally, the epilogue takes a last look at the communities today. By assessing the evolution of the communities in Detroit and Toronto the epilogue attempts to show the variation and similarities between the two communities in terms of cultural and ethnic heritage retention, a marker for community viability. 


\section{Chapter 2 - Malta in the British World}

The wind-swept islands of Malta, nestled in the heart of the Mediterranean, have long been the jewel in the crown of many expansive empires. The limestone archipelago's excellent harbors and central location give value to its strategic importance, masking its poverty of natural resources. It was those harbors and temporary refuge from the Ottoman Empire that led the Order of St. John to the islands. Ruled by the Order (1530-1798) as a surrogate for the Spanish Habsburgs, the Maltese populace enjoyed relative stability for two centuries. But as the world modernized, Malta lagged behind and its people grew increasingly frustrated. In 1798, Napoleon invaded and subsequently occupied Malta. Quickly the Maltese soured under the French thumb as the economy fell apart and corruption ran rampant. They then revolted and with the help of the British Royal Navy, expelled the French in 1800. The islands then transitioned into a British colony, recognized by the Congress of Vienna in 1815 . For the next century and a half Britain and Malta engaged in an awkward tango of shared power between imperial needs and domestic wishes.

This chapter endeavors to highlight the shaping of a new Maltese identity under British rule. The social construction of the Maltese identity hinged on their status within the imperial framework. In order to improve Maltese society, the British undertook massive reforms, including the restructuring of Malta's economy, introduction of public health measures, and the professionalization of bureaucracy. These measures contributed to a slow but visible shift in both the populace and their perceived identity as increasingly British. "Imperial needs" and "domestic wishes" of a British population become important players in their own right through this chapter. As Malta grew in importance to Britain, its position as a naval outpost made it an indispensable corner of the empire. The domestic wishes followed this imperial need, as keeping the populace 
loyal and happy became a difficult thing to manage by London. In part this was due to bureaucratic growth in Malta gave local politicians considerable leeway to run their own domestic affairs, furthering the "willing partner" narrative in Malta. This freedom to run internal affairs at times clashed with the overarching Imperial government and the needs of Empire, leading on several occasions to the dissolution of the local parliament.

As the century turned, it became increasingly critical from both an imperial and domestic view that certain issues could only be tackled with the collaboration of both governments. The most pressing of these was the problem of emigration. Politically, both governments understood that high unemployment did not bode well for the incumbent powers. Economically, the domestic government realized the islands had to be relieved of population or face massive unemployment and huge debts to cover social costs. Imperially, high unemployment and unrest could lead to revolt. Britain could ill afford to lose its prized naval base linking lucrative commerce from India to the homeland. For many in Britain, the decades of poorly executed domestic emigration schemes meant imperial power must solve the issue. No longer would emigration simply be a Maltese issue, but one that effected the Empire as a whole. In staggered steps, the two governments slowly moved towards a professionalization of emigration services. In order to achieve success, the Maltese emigrant needed to use all of the tools in the new arsenal of a British identity. By exploring the track record of Maltese migration throughout British rule, the slow success of a reshaping of identity becomes evident in the shifting attitude towards Malta's people abroad.

Owing to Malta's small size, Maltese identity has always been influenced by foreign ruling parties. Malta's history reflects the story of Mediterranean empires. Scholars point to the Phoenicians, spreading their nascent empire across the sea around $1000 \mathrm{BC}$, as the first to settle 
the islands. ${ }^{1}$ Other long periods of rule were established by the Romans, Arabs, and Sicilians as each exerted control in the region. However, much of the previous occupiers' influence on Maltese identity, aside from a language still based on Semitic roots, was overwhelmed by more recent - historically speaking - events. Gaining control of Malta in 1530, the most impactful of these foreign powers on the Maltese people was undoubtedly the Order of St. John. The rule by the Order re-established the Catholic Church's power and sway on the islands.

The next two centuries witnessed the Maltese actively reshape their identity under the Order. The Order's theocracy was firmly established after an unexpected victory over the Ottomans during the Great Siege of 1565. Celebrating this victory, prominent Maltese clergymen and historians of the era began to emphasize their Catholic and European roots, however legitimate some of these claims were. ${ }^{2}$ There did exist reason to doubt these claims. Malta experienced over 200 years of Arab rule from 869-1090 AD, with suggestions that Muslim influenced remained strong for at least another century. ${ }^{3}$ For example, the post of Bishop of

\footnotetext{
${ }^{1}$ Joseph Borg, "Brief History of the islands of Malta and Gozo," Malta Virtual Emigration Museum, http://www.maltamigration.com/about/malta.shtml; World Heritage List, "Megalithic Temples of Malta," United Nations Education Scientific and Cultural Organization, http://whc.unesco.org/en/list/132.

${ }^{2}$ Anthony T. Luttrell, "Approaches to Medieval Malta," in Medieval Malta: Studies on Malta before the Knights, ed. Anthony T. Luttrell (London: The British School at Rome, 1975), 1-2; Karla Mallette, "The Ramparts of Europe: The Invention of the Maltese Language," in European Modernity and the Arab Mediterranean: Toward a New Philology and a Counter Orientalism, (Philadelphia: University of Pennsylvania Press, 2010), 100-131; Goodwin, "Nationalism, National Identity, and Selected Issues of Race in Malta," 70-72. Goodwin goes into great depth about the amount of change necessary to alter the common history of the Maltese, writing "In an effort to prove that Maltese were "true" Europeans, some Maltese nationalists as early as the 1700s began to insist falsely that the Maltese language evolved from languages other than Arabic." Some of these "other" languages were guessed to be Etruscan or even Phoenician. He further deflates nationalist arguments by pointing to the conquest of Malta by Count Roger of Sicily saying "when Count Roger and his son Roger II extended their authority over southern parts of the Italian peninsula, Sicily, and Malta, in the $12^{\text {th }}$ century that all Muslims had been expelled at least from Malta. In reality, these two Norman rulers neither expelled all Muslims neither from southern Italy nor from Malta. They did not even restore a Catholic bishopric in Malta. Finally, he points to the $18^{\text {th }}$ century work of Gian Francesco Abela who wrote an "effort to portray Malta as innately European and Christian by deemphasizing periods during which Malta had especially strong links with Islam and nearby Africa." Joining Abela was a priest, Giuseppe Vella, who forged documents about the historical Arab past of Malta.

${ }^{3}$ Geoffrey Roper, review of Malta, by J.R. Thackrah, British Society for Middle Eastern Studies, Vol. 16, No. 2, (1989), 223. Roper claims that "Arab Muslim rule lasted for over 200 years and remained predominantly Muslim for at least a further century and a half." If this is correct, the lingering of Muslim culture suggests a high level of intrusion into Maltese society and culture. Even today, scholars debate this period of Maltese history with
} 
Malta went unfilled for centuries, lasting beyond Arab rule until $1156 .{ }^{4}$ It was with tremendous effort then that the remaking of Malta's identity as Catholic and European achieved success through the complete revival of the Catholic faith on the islands. Malta and its populace became known across Europe as a fervently Catholic nation, basking in the attention of Rome during the rule of a Catholic Order. ${ }^{5}$ This malleable identity did not just shift for religious reasons. The restructuring of Maltese identity through a re-conversion to Catholicism was critical to securing jobs under the Order. Without this religious marker, obtaining work would have presented serious challenges to locals. Presenting oneself as part of the European community brought trade benefits and work to the islanders. However, the jobs secured by individuals were hardly plentiful and politically the Order did little to modernize the islands. ${ }^{6}$

New social identities could not hide the poor record of the Order in attempting to create a modern economy, and subsequently the Order's hold on Malta began to slip. In the late $18^{\text {th }}$ century, tensions between local clergy and the Order ran high. The many failures, a lagging economy and the unflinchingly tight autocratic rule, led to six different riots between 1760 and $1775 .^{7}$ The same clergymen who wrote the Maltese history now actively fought to change their countryman's fortunes again. The pinnacle moment came during the Rebellion of the Priests on

some suggestion the Maltese continued their Christian practices in secret under Muslim rule, others find little evidence to support these claims. For additional reading, see Mario Buhagiar, "Medieval Churches in Malta," in Medieval Malta: Studies on Malta before the Knights, ed. Anthony T. Luttrell (London: The British School at Rome, 1975); Jeremy Johns, Review of The Making of Christian Malta, by Anthony Luttrell, Journal of Islamic Studies, Vol. 15, No. 1 (2004).

27.

${ }^{4}$ Brown, "Byzantine Malta: a Discussion of the Sources," 83; Luttrell, "Approaches to Medieval Malta,"

${ }^{5}$ Alessandra Stanley, "Malta Greets the Pope Like a Beloved Spa Client," New York Times, May 9, 2001. Malta was recently called a "kind of Club Med for popes, an overwhelmingly Catholic country," in the New York Times. Stanley writes that it has been a historically Catholic nation, falling into the trope of Malta being Catholic since the arrive of St. Paul thus ignoring or more likely blissfully unaware of Malta's Muslim past.

${ }^{6}$ Charles A. Price, Malta and the Maltese: A Study in Nineteenth Century Migration (Melbourne: Georgian House, 1954), 2.

${ }^{7}$ Price, Malta and the Maltese, xi. Price notes that the Maltese witnessed their economy fall further behind their equals in Europe, matching more closely the economies of North Africa and the Eastern Mediterranean. 
September 9,1775 , a brief uprising ultimately crushed by the Order. ${ }^{8}$ With events unfolding in continental Europe, notably the French Revolution, the Order's funds were sapped as much of their income depended on landed European estates. The situation on Malta deteriorated further. ${ }^{9}$ The fate of the Knights increasingly was sealed and their time in Malta was rapidly drawing to an end.

With Maltese ire high, change came quickly to the islands at the end of the eighteenth century. The rule of the Order collapsed without much resistance when Napoleon made his voyage east to Egypt. Without resources and out gunned, the Knights surrendered the islands to the French in $1798 .{ }^{10}$ Despite early hopes and grand plans, French rule did not improve Maltese day-to-day life and in fact generally made matters worse than before. A ransacking of the coffers combined with the lackluster auction of property formerly owned by the Order meant an even further impoverished Malta. Despite all of this, perhaps the largest mistake made by the French was the disfranchisement of the Catholic Church, now a cherished and powerful institution in Malta. ${ }^{11}$ Very quickly the Maltese rose against the French garrison and drove them into the

\footnotetext{
${ }^{8}$ Dennis Castillo, The Maltese Cross: A Strategic History of Malta (Westport, CT: Praeger, 2006), 93. A priest by the name of Gaetano Mannarino of Floriana took action. Noticing, or perhaps previously aware of the absence of the fleet from the Harbor, Mannarino led followers through the capital region capturing fortifications in St. Elmo and Valletta, raising the rudimentary Maltese flag. A symbol of revolt, the flag they hoped would inspire uprising across the city and spread from there over the rest of the island. However, the revolution so hoped for by the local clergy and noblemen never materialized. The Order quickly moved to restore control, capturing 400 rebels, executing three and imprisoning the rest.

${ }^{9}$ Desmond Gregory, Malta, Britain, and the European Powers, 1793-1815 (Cranbury, NJ: Associated University Presses, Inc., 1996), 35; Goodwin, "Nationalism, National Identity, and Selected Issues of Race in Malta," X. The growing unsettled continent meant funds were being cut off for the Order who largely relied on private estates and church properties to fund their rule in Malta. As Republican governments came to power, many of these religious properties were seized by national governments, particularly the French.

${ }^{10}$ Stefan Goodwin, "Nationalism, National Identity, and Selected Issues of Race in Malta," in Colonial Encounters: Maltese Experiences of British Rule, 1800-1970s eds. John Chircop and Stefan Goodwin, (Qormi, Malta: Horizons Publishers, 2015), 67.

${ }^{11}$ Gregory, Malta, Britain, and the European Powers, 55. Gregory describes the lofty goals for economic and political development in Malta advanced by French authorities. These included the reorganization of education which would create an educated core in Malta, with the best educated in France themselves. From here, domestic growth would occur. The sale of property owned by the Order, which the rural poor wished to see turned over to the public, brought in far less revenue than expected.
} 
walled city of Valletta. Calls to the international community for aid were answered by the British, seeking not necessarily to occupy Malta for itself but rather to deny its bitter enemy France the possession of the islands. ${ }^{12}$

At the very moment of victory over France in Malta, two dueling narratives emerged, setting the tone for Maltese-British relations over the next century and a half. From the stand point of Britain, the victory in Malta was completely imperial. Denying Napoleon his "watchtower of the Mediterranean" was a wonderful feather in the cap of a much wider war between the imperial rivals. ${ }^{13}$ But the territory itself mattered little to the British, and the thought of long-term occupation was not favorable. Many MPs claimed that Malta would never be worth it in the long run. It would be a drain on finances when other ports - perhaps even better ports could be obtained for less operational costs. There was a measure of truth to those arguments. The facilities in Malta were in disrepair, the economy ruined, and the cost of holding the islands against France could potentially spiral out of control. ${ }^{14}$ The question remained, who then would control Malta? By the eighteenth century, the Order of St. John was universally despised in Malta for ruining the local economy and health standards, and though rightful legal owners, their degraded state of operation eliminated them from contention. The idea of Malta falling under an international legal protectorate was also floated, but the British feared French influence would slowly wrestle the islands back from an international community unwilling to defend Malta properly. The only real option was British control. ${ }^{15}$

\footnotetext{
${ }^{12}$ Gregory, Malta, Britain, and the European Powers, 88.

${ }^{13}$ Ibid.

${ }^{14}$ Ibid., 282.

${ }^{15}$ Gregory discusses in his work Malta, Britain, and the European Powers, how one option for Malta postFrench rule would have been an international cooperative jointly run by the Russians and Neapolitans. But the lack of serious commitment by either of those nations worried Britain.
} 
The narrative coming from the Maltese reflected Malta's entrance into Empire in terms of a willing partnership. Much of this conceptual identification resided in the Maltese belief that calling for British aid to oust the French meant Malta willingly entered the Empire not as a conquered people but as partners. This attitude amongst the Maltese was evident from the first moments of victory. Maltese soldiers bitterly complained when they were not compensated with any share of the prize money from the capture of Valletta, and were further enraged when the final surrender was only signed between the French and British. All of this occurred despite the fact that the vast majority of fighting men were Maltese. ${ }^{16}$ While these moments do not show partnership, they illustrate Maltese belief that there should have been partnership and that, in their minds, Maltese citizenship was equal to the British. The feeling of "partnership" only grew stronger as the British continued to delay any official decision about Malta's future role. This delay, coupled with further snubs of Maltese wishes, continued despite active attempts by Maltese politicians pushing for resolution during the interim period from French rule to official British control lasting until $1815 .{ }^{17}$ These slights, and more importantly the continual Maltese attempts to represent themselves on equal footing with the British highlight the roots of the domestic-imperial divide that both sides dealt with going forward.

\section{Crafting a British Identity in Malta}

In 1815, when Malta entered into the Empire, they did so during a shift in the way the empire was structured. The imperial shift, occurring in the early $19^{\text {th }}$ century from an empire

\footnotetext{
${ }^{16}$ Gregory, Malta, Britain, and the European Powers, 91-93. It is at the end of the siege in which Gregory mentions the discontent spreading among allies and Maltese alike. In response to the lack of shared prize money, British officials "reported that guns had been sabotaged and a howitzer removed." But further insulting was the surrender agreement signed only between the British and the French, excluding both the Maltese and Neapolitans who fought as regulars in the siege, as well as the Russians and the Order who both laid claim to the islands of Malta. These snubs led to resentment among the great powers over the British control at Malta.

${ }^{17}$ Ibid., 196.
} 
based on settler colonies to economic colonies, exemplified by the loss of the United States of America and the reorganization of India, meant a new type of "British" identity was born across the Empire. ${ }^{18}$ Peoples within the same locale could be simultaneously viewed as both the same and different from British people, depending on which official you spoke with and about which group of colonized people you meant. This was particularly true in the case of India. ${ }^{19}$

Infinitesimally smaller than India, one would assume that the British found it much easier to classify the Maltese and their rights within the imperial framework. However, thanks to Malta's position on the fringe of Europe and due largely to the type of hands off, military-first governance the British hoped to achieve on the islands, this was not the case.

Unlike other colonies Malta had no natural resources to be plundered and no way to survive on its own. It was valued solely for its strategic location and harbors. Therefore, Malta had to be cared for gently, and to make the islands a floating fortress its populace had to be brought up closer towards the standards of the British world. To create a colony where Britain could deploy its military-first governance required a huge investment by the British to revamp Malta's economy and society, from things like public health to education and a professionalization of the political class. This meant, with reluctance, the British became active in Maltese domestic affairs in order to create a fortress colony worthy of British military men. To serve the men of the British military, and to create a populace capable of supplementing the military stationed at Malta, this makeover also needed to actively reshape the Maltese people

${ }^{18}$ P.J. Marshall, The Making and Unmaking of Empires: Britain, India, and America, 1750-1783 (Oxford: Oxford University Press, 2005), 379. Marshall argues that this shift from settler colonies to economic is really part of the same imperial phase, pushing back against those who desire to split the concept into a "first and second empire [which has] very little relevance for this period...If [historians] recognize, however, that the making of empire in India and the unmaking of empire in America belong to the same phase of Britain's imperial history, what historians choose to call it is not then a matter of much consequence."

${ }^{19}$ Thomas Metcalf, Ideologies of the Raj (Cambridge, UK: Cambridge University Press, 1995), x. “... at no time was the British vision of India ever informed by a single coherent set of ideas. To the contrary, the ideals sustaining the imperial enterprise in India were always shot through with contradiction and inconsistency." 
themselves into Britishers. This remaking of identity and society blurred the lines between imperial needs and domestic wants. Despite the wishes of London to remain in Malta only for military purposes, the necessity of remaking Malta made it difficult for the whole of British occupation to ever fully step away from domestic affairs. To build a fortress colony worthy of the imperial forces, Malta's domestic needs, things like education, job training, health, and overall economy, had to be addressed. That task at the start of imperial occupation was immense and needed immediate remedy.

The first project tackled was the complete overhaul of Malta's economy. The economic well-being of the islanders was poor prior to British rule, and the introduction of Malta into the commonwealth brought a mixed bag of economic fortune, though mostly ruined the rural industries. The Maltese cotton industry, worth an estimated half a million pounds to the Maltese economy by 1800 stalled. Pressure from Egyptian cotton, and Imperial trade policies that allowed discrimination in markets against Maltese cotton, led to the rapid demise of the industry. By 1824, the Maltese cotton industry was cut in half. Even economic growth in trade and local industry brought by the British, which was not insignificant, could not offset the loss. ${ }^{20}$ So important was Maltese cotton in the past that it earned the label as the "backbone of the island's own industry." ${ }^{21}$ Collapsing in tandem with the cotton industry was nearly the entire rural

${ }^{20}$ Price, Malta and the Maltese, 2-5. Price writes that cotton was exported chiefly to Spain and by 1800 estimated at " $£ 500,000$ per annum." It was an industry that "a large part of the community shared, from the farmer who 'abandoned almost every species of culture' for it, to the numerous persons in every town and village engaged in its spinning and weaving... Any chance of a great post-war revival of cotton faded rapidly before the appearance of cheap Egyptian wool and yarn. Mehemet Ali's endeavours to create a new industry in 1817 grew steadily more successful, keeping the price of cotton below that which Maltese farmers, with their small intensive fields, could profitably cultivate the crop on a large scale; by 1824 Malta was complaining that local cotton 'was supplanted in almost every port by the novel introduction of the same article at a cheaper rate from Egypt.' Nor were matters improved by various commercial treaties between Britain and European countries such as Naples, which enabled discrimination against Maltese cotton yarn. In the opinion of reliable observers the cotton trade of the twenties and thirties was less than half the value obtained during the late $18^{\text {th }}$ century."

$$
{ }^{21} \text { Ibid. }
$$


economy of Malta. Spinners, weavers, and other craft jobs associated with cotton production disappeared as demand waned.

Though the decline of the Maltese cotton industry was not completely offset by other economic growth factors, emerging industries drew the unemployed of Malta from their rural origins towards the urban core centered on Malta's ports. In part due to Napoleon's continental system of the early 1800 s, Malta's importance as a center of British trade brought about a growth in trade goods and a booming financial sector. By 1812, over forty percent of British Southern European trade passed through Maltese harbors, totaling nearly $£ 5$ million of trade goods and spurring the establishment of 60 British firms and 30 new Maltese firms dedicated specifically to global trade. ${ }^{22}$ Furthermore, by the mid-century the Maltese financial sector experienced rapid growth. Three major banks opened in the early years of the century and as these were largely funded by wealthier Maltese individuals, the industry acted as one of the few where native Maltese could obtain good employment without direct British patronage. ${ }^{23}$ With a focus on building a fleet of Malta-built, trans-Atlantic capable ships, Biagio Tagliaferro e Figli-one of the most successful Maltese based banks - brought commercial business to the growing military demands in Malta's bustling Dockyards. However, that is not to suggest that these banks did not enjoy the benefits of Empire. Biagio Tagliaferro established its clout by plying British trade routes. Outside of British trade, the merchant fleet saw huge booms of growth transporting British troops during the Crimean War and took full advantage of the opening of the Suez Canal. $^{24}$

\footnotetext{
${ }^{22}$ Henry Frendo, "Ports, Ships and Money: The Origins of Corporate Banking in Valletta," Journal of Mediterranean Studies, Vol. 12, No. 2 (2002), 330-331.

${ }^{23}$ Ibid., 336.

24 Ibid., 337-338. Frendo notes that the Biagio Tagliaferro was established by a Genoese merchant in Valletta, but heavily invested in domestic Maltese industry. He writes, "By 1822 Tagliaferro already owned five ships which operated mainly between England, Malta, and Black Sea ports...By 1854 - a year which saw the commencement of, as it turned out, a very profitable war for Malta, conducted in and around the Crimean peninsula
} 
The growth of industry centered on Malta's Dockyard from both a military and commercial standpoint required investment in repair and modernization of Malta's ports. As the rural industries collapsed, almost all of the new jobs in Malta concentrated around the harbors and urban centers lending no real relief to those in the rural regions. Major works over the first century of rule like the construction of new dry docks and a new break wall in the Grand Harbor coupled with several major conflicts to bring a fairly steady flow of work. ${ }^{25}$ The Crimean War, lasting from 1853-1856, proved immensely lucrative for Malta's commercial interests and brought about the first real opportunity to prove itself a worthy port for the Royal Navy. With the conflict came further imperial jobs, investment, and more importantly an increase in the imperial payroll. ${ }^{26}$ The influx of work in the cities drew Maltese from depressed rural regions of the country, creating an increasingly urban population. These types of employment, coupled with the crippling of Malta's rural economy, birthed a workforce increasingly dependent on imperial funds despite Britain's original wish to remain on Malta solely for military needs.

In order to accommodate the growth of industrial work, Maltese and British politicians pushed to build a more robust education system. The main aim was to both improve the economic conditions of the colony by providing an educated populace capable of industrial work

- we find Tagliaferro forming a council to help the government run the commercial quays and administer the lighthouses." Furthermore, he argues that the growth of financial industry and the business in the Dockyard became the mainstay of the Maltese economy, which was increasingly Imperially oriented. By the 1860s, Maltese harbors welcomed 3,000 ships annually with tonnage never dropping below one million tons of goods moving through the harbors.

${ }^{25}$ Price, Malta and the Maltese, 187. "The sudden expansion of imperial spending in the [1850s and 1860s] fifties and sixties showed that Great Britain placed Val[1]etta high on her list of first-class naval bases...she was at last prepared to pay the Maltese people an exceedingly high 'rent' for using their island harbours. But she was not ready to pay this rent in any consistent or steady manner; she felt herself bound to do no more than pay in floods or in driblets according to the day to day requirements of imperial policy. Largely as a result, from 1854 onwards Malta experienced a series of booms and depressions of great violence, the depressions being sufficiently numerous to force many Maltese families into conditions of 'misery' and 'vice', to keep the problem of reducancy before contemporary minds..."

${ }^{26}$ Ibid. 
and to prepare potential Maltese emigrants for success overseas. ${ }^{27}$ Gripped by the Industrial Revolution, the concept of skills training education and compulsory attendance grew in England and across the continent. In Malta, officials pushed as early as 1836 for greater increases in the educational base of the colony. The growth of educational facilities across the islands attempted to both provide a skilled labor base for industrial growth and tie Malta's working class closer to Britain through British educational systems.

The great problem for Maltese educational obtainment was a lack of domestic industry. These economic sectors were responsible for the growth of general and skilled education training on the continent and England. The severe lack of technical and industrial jobs in Malta meant that education was not a priority for many. Traditional work in agriculture and cottage industries in Malta was best learned through practice rather than schooling. Not only did Malta lack industrial work in the $19^{\text {th }}$ century, but analysis of colonial economies showed that "investment in the new industries by the dominant power...tended to create a dual employment structure, one based on modern, skills-oriented production, the other on traditional activity." ${ }^{28}$ In Malta, this meant two employment tracks, one based on growing production as highlighted previously in the dockyards and the other on agriculture and rural industries which required little to no education. Maltese education therefore languished in the rural reaches of the islands. Malta's most successful school, the Dockyard School, was established in 1858 and served those students in the urban settlements around the growing work in the Grand Harbor. ${ }^{29}$ The technical training and educational background provided at the Dockyard School launched the career of hundreds,

\footnotetext{
${ }^{27}$ Ronald G. Sultana, Yesterday's Schools: Readings In Maltese Educational History. (San Gwann, Malta: Publishers' Enterprises Group Ltd., 2001), 78. Education as early as 1836 was seen as a way to rid the islands of excess population, making it easier for Maltese to settle into nearby regions such as North Africa.

${ }^{28}$ Ibid., 85.

${ }^{29}$ Ibid., 86. The only place in Malta where high paying jobs were available was the dockyard. "This explains why the Dockyard School was so popular since its inception in 1958 up to its dismantling a hundred years later...the school had its heyday in the late $19^{\text {th }}$ century and the first three decades of the $20^{\text {th }}$ century."
} 
perhaps thousands, of Maltese skilled laborers in the late $19^{\text {th }}$ and early $20^{\text {th }}$ century.

Furthermore, when was immigration became imperial and domestic policy, it was these individuals who possessed the skill sets that Maltese and British officials sought for a successful migrant candidate.

Beyond the problems of the economy and education, a lack of public health measures presented clear hurdles for the British. Under the Order of St. Johns, Malta fell behind her European counterparts in terms of sanitation and health. A simple lack of civic development like closed sewers and a more modern healthcare infrastructure made public health issues a top priority. While those living in urban areas lacked modern urban infrastructure to fight preventable disease, it was even worse for those outside of the cities. Homes in rural Malta generally had nothing more than straw floors and a small hole in the corner of a room to act as a toilet facility. The Maltese themselves, outside of the richest few, lived a rather dirty life in small stone homes, built without sanitary conditions in mind. ${ }^{30}$ Diseases, long eradicated in Britain ran rampant among both the local population and passing military units. While British authorities may have sought improvements in local health for humanitarian reasons, ultimately the priority was to make Malta habitable for English soldiers and sailors passing through and stationed on the islands.

The most difficult of these illnesses to deal with was known as "Malta Fever." While other common diseases were understood by British physicians and easily remedied through public health measures, "Malta Fever" continued to pester British military men. Though not particularly deadly, the effects physically weakened the garrisons on Malta as men required several days, if not weeks, in recovery. The culprit, discovered in part by Maltese doctor

\footnotetext{
${ }^{30}$ Price, Malta and the Maltese, 30. Price discusses the type of home construction in Malta that generally featured few windows for ventilation.
} 
Temistokle Zammit, was found to be micrococcus, a bacteria spread through infected goats. This caused an imperial crackdown on goat herding for public safety measures, resulting in seismic shifts in Maltese culture. Goat herding and the delivery of fresh goat milk to citizens across the island was a daily occurrence. Accomplishing this meant moving whole herds into cities during the morning and back out of the cities in the afternoon. In Valletta, for example, where thousands of goats tramped inside the walled city, the virus spread rampantly, even to wealthier citizens. ${ }^{31}$ The British began a long, slow process of attempting to dismantle this informal system, shaking the Maltese way of life and further destabilizing the Maltese economy.

All of these efforts hoped to achieve one common goal, the development of a stable domestic Malta. From the very first moments of Maltese incorporation into the Empire, officials worked to implement plans that would keep Britain free from the high costs of domestic welfare. Modernizing the economy and health systems represented just one half of the project. The other key to keeping costs low on Malta was a movement towards a less hands-on imperial government through the implementation of a domestic parliament to handle internal affairs. While on paper this plan seemed logical, the type of relationship that developed between Britain and Malta made it much more difficult in practice. Even with improving health systems, the lack of an independent economy gave Maltese elected officials an opening to push for greater concessions within the imperial system. Generally, in return for the use of Malta's harbors and control of Malta's economy these concessions revolved around more rights of equality for Maltese citizens in the imperial world. These assertions and pushes for greater equality did result

${ }^{31}$ H. Vivian Wyatt, "Brucellosis and Maltese goats in the Mediterranean," in Colonial Encounters: Maltese Experiences of British Rule, 1800-1970s eds. John Chircop and Stefan Goodwin, (Qormi, Malta: Horizons Publishers, 2015), 202. Wyatt describes the process as “4000 or 5000 goats...driven into Valletta every morning and afternoon, to be milked in the street. As there was no refrigeration, milk was bought twice or more a day. People did not use the pint to measure and so bought two pence worth of milk. Boiling goats' milk destroyed the flavour." 
in the withdrawal of Maltese constitutions on several occasions. ${ }^{32}$ For the British, the Maltese narrative of partnership was only begrudgingly understood, but incredibly difficult to manage.

However, this idea of an imperial partnership was critical to the developing British

Maltese identity. The fact that Maltese elected officials continue to hound Britain on the equality of Maltese citizens under law, even a hundred years after incorporation, shows that this idea mattered greatly to the Maltese psyche. During a meeting with Winston Churchill in 1907 several Maltese elected officials recounted this partnership and its meaning of equality. One Council of Government member, Dr. Merchica, stated,

I need not remind you, Sir, that the Maltese have of their own free will given themselves up to Great Britain...the Maltese gave themselves up to the protection of the English people solely because they knew that liberty had been the birthright of the English people from time immemorial... Our forefathers had every reason to expect a liberal treatment in the shadow of the British flag... Why should not the Maltese possess this liberty when they can boast a civilization far anterior to that of many European nations? Why should the Maltese be behind all other nations? Why should not the Maltese have liberty in the form of a constitutional government limited to the administration of purely local affairs? ${ }^{33}$

With an economy increasingly obedient to imperial direction, the Maltese desire for equality on local affairs grew. This goal, as illustrated by the statement above, was not a drive for total independence. Here we see the pinnacle of this "partnership" idea. The Maltese saw themselves

\footnotetext{
${ }^{32}$ Malta went through several constitutions during its colonial history. As its government became problematic to London, the frequent solution was to simply pull the constitution and return to Malta to status of Crown Colony until tensions settled and a new constitution could be agreed upon. There were four total constitutions in the $1800 \mathrm{~s}-1813,1835,1849,1887$ - and seven in the 1900s - 1903, 1921, 1936, 1939, 1947, 1959, and 1961 - until independence. http://melitensiawth.com/incoming/Index/Scientia\%20(Malta)/Scientia.\%2016 (1950)3(Jul.-Sept.)/01.pdf.

${ }^{33}$ Winston Churchill later proclaims in his report following the meeting with Maltese elected officials that it was unwise and unfair for the British to dismiss "the claims to any measure of self-government even in respect of their own purely local affairs of an ancient and highly intelligent community of more than 200,000 Europeans who entered the British Empire of their own free well." Harry Barron, "Political Condition of Malta - No. 1 The ACTING GOVERNOR to the SECRETARY OF STATE.” 19 June 1907, CO 883/7/4, Colonial Office Records, The National Archives - United Kingdom, Kew, England, 6. Winston Churchill, "Political Condition of Malta Memorandum by Mr. Winston Churchill, M.P.," January 1908, CO 883/7/4, Colonial Office Records, The National Archives - United Kingdom, Kew, England, 9.
} 
as critical partners to the imperial project. Instead of pushing for total independence, they sought a greater share of power in their own realm of the empire as Maltese "Britishers."

The Maltese drive for greater rights in 1907 was not ignored by Britain, but launched a complex discussion of Malta's status within the Empire. Despite Maltese self-identification as Britishers, the question floating around parliamentary circles in London was how do you give, or was it even possible to give, a fortress-colony a constitution? From the British view, Malta was nothing more than a floating fortress, and so engrained was this belief that the saying "Malta has no more right to a constitution than has a battleship" was widely used. ${ }^{34}$ Even Maltese statesmen did not completely disagree with the classification of Malta as a military fortress. However, they argued that the best defended fortress was one with a content population. As the Elected Council of Government in Malta met with Mr. Churchill one member, Cachia Zammit, stated, "The Imperial Government should be reminded that Malta is something more than a military station, and that the claims of the civil community are not to be ignored." ${ }^{35}$ Merchica likewise alluded to this notion saying, "I may in conclusion submit that England can rely more on the contented Maltese than on its garrison, because a contented people in a fortress is the best defence of the fortress itself.",36

Throughout the discussion of Malta's status as fortress or colony, officials in Britain acknowledged that the Maltese, being loyal patriots, should be given some degree of rights. This loyalty was apparently "proverbial" and was "proclaimed in and out of Parliament...in the British press, and last but not least by Mr. Chamberlain himself." ${ }^{37}$ Much of the problem in

\footnotetext{
${ }^{34}$ Winston Churchill, "Political Condition of Malta - Memorandum by Mr. Winston Churchill, M.P.," January 1908, CO 883/7/4, Colonial Office Records, The National Archives - United Kingdom, Kew, England, 9.

${ }^{35}$ Harry Barron, "Political Condition of Malta - No. 1 The ACTING GOVERNOR to the SECRETARY OF STATE.” 19 June 1907, CO 883/7/4, Colonial Office Records, The National Archives - United Kingdom, Kew, England, 4-5.

${ }^{36}$ Ibid., 6.

${ }^{37}$ Ibid., 5.
} 
acknowledging how this loyalty related to political power was obscured by the type of governor running Malta at any singular point. Churchill claimed that governors who treated Maltese poorly only exacerbated the situation, pushing the Maltese towards further anger and rebellion, while those who operated under the ideals of co-operation were able to bridge the divide. This rotating attitude of governors seemingly existed for most of Malta's colonial period. ${ }^{38}$ But even if acknowledging this loyalty, and the Maltese as equal or near-equal to the English, was critical to the formation of a Maltese Britisher identity, it did not smooth over the question of how or even if domestic rights could be introduced that would not hamper imperial needs.

Transiting the Maltese towards a form of self-governance through the granting of a domestic parliament and political rights was the last critical piece of Britishness in the Maltese identity. Eventually this self-governance came in the implementation of the 1921 Constitution which gave Malta a governmental Diarchy, an imperial government run by the Governor and a

\footnotetext{
${ }^{38}$ Churchill discussed the differences of two governors of Malta in 1908, "I think it is probable that these feelings have been exacerbated by the course adopted by the late Governor of treating the elected members as if they were persons under a ban, and of excluding them, as I am credibly informed, from all social recognition at Government House. [much like the ebbs and flows of governors in Malta] The tact of General Barron has undoubtedly rendered this situation less acute, and there is a very distinct feeling of co-operation and sympathy to be noticed at the present. But this is only an eddy, and upon the whole I am not prepared to deny the essential justice of the complaint made to me." Winston Churchill, "Political Condition of Malta - Memorandum by Mr. Winston Churchill, M.P.," January 1908, CO 883/7/4, Colonial Office Records, The National Archives - United Kingdom, Kew, England, 9.

Later governors continued this back and forth of ideologies. See Gov. Herbert Plumer and Gov. Walter Congreve. For Plumer, Malta and its people should be incorporated into the Empire as European peoples, part of a grand Imperial vision, yet his successor made several statements that wished to see a stricter delineation between the locals and true British subjects. This difference in governor attitudes is pointed out by American Consular Officer Philip Adams in 1925 when he expresses in a letter back to Washington D.C. that Britain seemingly operates in Malta, which has Self-Government by 1925, differently than elsewhere in the colonies. "It is said that a former Governor, Lord Plumer, was very anxious to break down the social barrier, but that, with all the prestige conferred upon him as the Representative of Royalty, he was unable to do very much in that regard owing to the stubborn resistance offered by the Army and Navy contingents...In the more arbitrary types of Crown Colony Government, that is government by a Council in which there is a majority of British members, abstinence from social intercourse with the governed classes is to some degree a protective measure, for a governing class is not, under such conditions, amenable to the social pressure which the governed element would bring to bear against unpopular measures. On the other hand, when a large measure of Self-Government has been granted, such social aloofness appears to fulfill no useful purpose and to be politically inexpedient as well." Philip Adams, "Survey of the British and Maltese Relations" Malta to the State Department, November 1925, 849B RG 59, Records of the Department of State, NARA II, College Park, MD, 4-5.
} 
domestic government run by an elected Prime Minister and parliament. ${ }^{39}$ Arriving at that point, and even after the constitution passed, was fraught with challenging political conceptions. The most important of these revolved around the delineation between imperial and local issues. Once more Churchill expressed the difficulties that lay ahead long before the constitution was issued.

In 1908 he wrote,

It may be laid down as axiomatic that the ultimate control of all matters affecting Imperial interests must be reserved to the Governor of the Fortress. It may, I think, also be promised that all purely local questions should be left to the Maltese to settle according to their lights. But the difficulty arises, first in classifying questions in either of these two categories - especially in view of the fact that the same question may sometime lie in one and sometimes in the other category - and also of devising an instrument of government which shall at one moment surrender, and at another assert, Imperial control. ${ }^{40}$

Finding a way to both surrender and assert Imperial control in Malta remained a problem for the entirety of British control. Several issues represented both imperial and domestic concerns, from education, to health care and the economy. But the most pressing - and most difficult to solve was that of emigration.

\section{Emigration: A Britisher Issue}

The issue of emigration from Malta was a centuries old problem. Malta’s population historically stretched the scant resources and employment of the islands thin. For most of its history the solution to a lack of ability to provide for its citizens meant emigration was a national necessity. ${ }^{41}$ Under British rule, thousands of Maltese continued to head abroad in hopes of

\footnotetext{
${ }^{39}$ While several documents from the era claim the Diarchy was "unique" or specific only to Malta, that was not the case in the Empire. In fact, Britain established similar governance through the Government of India Act in 1919. What was different about the Maltese Diarchy was the size of the colony and the difficulty to separate imperial desires for defense with domestic programs.

${ }^{40}$ Winston Churchill, "Political Condition of Malta - Memorandum by Mr. Winston Churchill, M.P.," January 1908, CO 883/7/4, Colonial Office Records, The National Archives - United Kingdom, Kew, England, 9.

${ }^{41}$ Maltese individuals throughout the $17^{\text {th }}$ and $18^{\text {th }}$ centuries often left Malta for work across the Mediterranean including Libya, Tunisia, Egypt, the Levant, Italy, Greece, and Spain. For much of these centuries, the standard of living was on par with Malta, if not ahead of Malta.
} 
creating a better life for themselves. While later migrations in the $20^{\text {th }}$ century to the United States, Canada, and Australia were successful in relieving the islands of surplus population by providing long-term economic security for the migrants, they also raised the very question Churchill raised in 1908, about the roles an imperial government against those of a domestic one. Nineteenth century migrations were largely failures as Maltese men went abroad for only short periods of time before returning to start families in Malta. The closeness of their migration, mostly contained within the boundaries of the Mediterranean, and the slipping standards of living in North Africa kept any of the migration from remaining permanent. These waves of migration also tested the new British identity being crafted on Malta and within the Maltese population.

The migration problems of the 1800 s exhibit how poorly managed emigration led to a very mixed perception of Maltese identity. Encouraged by new avenues for migration as part of the British empire, places like Egypt and Gibraltar, and the protection of British consuls in other Mediterranean locales like Libya, the Maltese had more options than ever before. For the most part however, those looking to go abroad were those displaced by British actions in Malta during the $19^{\text {th }}$ century. By retooling the Maltese economy, chiefly the destruction of the cotton industry and the disruption of the traditional goat herding economy, British actions inadvertently created a mass of economic migrants looking abroad for survival. These economic refugees were often the least educated people and ones with the fewest real chances of success away from home. Furthermore, with no direction from any government source these migrants simply packed their bags and headed abroad attempting to find work in haphazard movements. The failure to establish the Maltese as truly British, coupled with poor governance that destroyed the local Maltese economy and looked the other way while private citizens organized emigration policy, 
led directly to the death spiral of Maltese emigration with disastrous consequences for future generations.

By the mid-nineteenth century the Maltese, looking for economic opportunity in close proximity to their homeland, began to fill labor needs on Gibraltar. Before long, the reemergence of "Malta Fever" on Gibraltar, a disease previously eradicated from the Rock, was attributed to Maltese goat-herders who had sought economic refuge. Clearly, Britain's crackdown on "Malta Fever" in Malta simply shifted the problem within the empire. The rebirth of the disease in Gibraltar exposed imperial views of the Maltese, and showed that much work still remained to remake the Maltese as good British subjects. One response to the outbreak came from the Bishop of Gibraltar who called for an immediate halt to Maltese immigration, referring to the Maltese as weeds. The Bishop wrote that "Once they have landed here, it is not easy to send them back to their island home or to get rid of them, particularly as they are excessively hardy and inured to want, so that they need but little to live on, and that little is readily found among their own." 42 Later, in 1885, The Times of London linked the Maltese to an outbreak of cholera in Gibraltar writing,

...the new comers [Maltese] proved to be the most troublesome section of the population...These unwelcome British subjects, who speak a bastard Arabic, are a bloodthirsty set. They never wear shoes, but creep about silently on bare feet. The criminals among them, of whom, unfortunately, there is a goodly proportion, can scarcely be qualified as the bold burglar type. They are better described as what are technically called 'area sneaks.' [emphasis added $]^{43}$

Through the writings of the Bishop and others involved in the colonial apparatus in Gibraltar, it is easy to see that the Maltese were not yet able to claim a true British identity. The free

${ }^{42}$ Lianne Tripp and Lawrence A. Sawchuk, "Undulant Fever: Colonialism, Culture, and Compliancy," in Colonial Encounters: Maltese Experiences of British Rule, 1800-1970s eds. John Chircop and Stefan Goodwin, (Qormi, Malta: Horizons Publishers, 2015), 231.

${ }^{43}$ Ibid., 232. 
movement of Maltese people to Gibraltar greatly damaged their reputation as a people and desirability as migrants.

The disdain for Maltese migrants continued in the Mediterranean for decades, even into the early $20^{\text {th }}$ century. The one major improvement in the half century since Maltese began migrating to Gibraltar and other British possessions was a change in official British attitudes towards them. Changing British attitudes did not however change the local population's attitude about these migrants. Many in the local communities continued to refer to them in disparaging terms. For example, the Commandant of Egyptian Police claimed in 1910 that the Maltese are "of no use to themselves, and only a burden to others. They have no profession or means of life, they loaf about by day and sleep in waste places at night, making themselves a nuisance to the Police..." ${ }^{44}$ The major change, however, was a perceptible difference of British attitude towards these migrants. No longer were they treated as outside of the British world but rather were given the protections and aid that British subjects could expect in Egypt. ${ }^{45}$ The softening of the British response to Maltese emigration problems grew in part out of necessity.

At the turn of the century, the question repeatedly asked in government circles was who is a British subject, who is a Maltese subject, and ultimately, what is the difference? Increasingly the problem grew beyond simply losing face on an international level. Both the Maltese and Imperial governments began to see emigration as a joint problem as vagabonds and destitute

\footnotetext{
${ }^{44}$ D.A. Cameron, "British Consual-General, Alexandria, to Governor, Malta," 22 December 1911. CO 883/8, Colonial Office Records, The National Archives - United Kingdom, Kew, England, 10-11.

45 "As a rule I find little difficulty in dealing with these unfortunates; they have been driven by hunger to seek a living here; they fail, and come to the Consulate; little or no relief is given to the men, but they are ordered to report themselves at this Office every morning till a vessel is ready to take them back to Malta. There is no truculence or demand for board or lodging. The men who come before me are exceedingly quiet and respectful... he has committed no offence in being without a Maltese passport, and, as there is no doubt that he is a Maltese by his distinctive name and speech, it would be unlawful for me to tell the Egyptian Police seriously that he was to be treated as a local Ottoman subject." D.A. Cameron, "British Consual-General, Alexandria, to Governor, Malta," 22 December 1911. CO 883/8, Colonial Office Records, The National Archives - United Kingdom, Kew, England, 1011.
} 
Maltese British subjects applied for aid en masse. While those in Egypt applied directly to the British consulates, there also arose the question of which government would pay for invalids and hospitalized Maltese British subjects overseas. Particularly in North African countries like Libya and Tunis, the question of how to handle these vagabonds challenged the emerging governmental partnership in Malta. While both governments accepted that persons born to Maltese parents outside of Malta are British subjects first, the question lingered over those Maltese who had been successful in emigrating and established themselves in a new country. ${ }^{46}$

What quickly became clear was that exclusively Mediterranean migration would not suffice for Malta. Too often those migrants who left for nearby destinations returned home when job conditions improved, slowing economic recovery and overburdening the scarce jobs. For many who were able to obtain work, the prospects of stable employment at home encouraged young men to think of marriage and starting families. ${ }^{47}$ As the newly returned migrants settled back into a normal routine of life, population numbers once again rose, often coming just before the next economic slump in Malta. This of course had disastrous results. Beyond that, the pattern of leaving Malta for the shores of North Africa became increasingly difficult as the economies of the region began to lag behind European standards. If the Maltese were to find success at all, it would entail migrating be further abroad, taking advantage of their new British association to land in distant but economically capable lands.

${ }^{46}$ Those migrants who left for Libya and Tunisia made up large communities of Maltese. By the 1910s, the question of how to care for those who require hospital stays or other types of government assistance becomes a major sticking point on which government will foot the bill. Are they Maltese or are they British? On the whole, the Maltese communities, particularly in Libya are better off than those in Egypt and Gibraltar. Sir Walter Congreve, "Diary of Walter Congreve, 1924-1927," D1057/0/5/4, Staffordshire and Stoke On Trent Archive, Staffordshire, England, pg. 43-44; J.H. Thomas, "The SECRETARY OF STATE to the GOVERNOR," 13 May 1924. CO 883/8, Colonial Office Records, The National Archives - United Kingdom, Kew, England, 1.

${ }^{47}$ Barry York, Empire and Race: The Maltese in Australia, 1881-1949 (Kensington, NSW: New South Wales University Press, 1990), 33. 
For both the British and Maltese, the vast "empty Dominions" of Australia and Canada held the most promise for success. Personally advocated for and negotiated by Maltese Cabinet Member Francesco Decesare, the largest and most concerted effort to establish Maltese in Australia occurred in the 1870s. It was believed that a combination of good climate and governance as British subjects would agree with the Maltese. These earliest attempts to direct migration to far flung regions of the world failed spectacularly, highlighted by the fateful S.S. Nudea colony. In this case, 61 Maltese contract laborers signed to work on a Sugar Cane farm near Townsville, Australia. Upon arrival, however, the Maltese contingent quickly fell apart. Several of the group began to learn of the dangerous conditions of swampy land, dangerous animals, and difficult work. Quickly, many changed their mind and went into town looking for other work. Not only did this act break their contracts, but also their appearance further damaged hopes of other employment. Those who left for town arrived looking ragged as they left Malta ill-prepared for the long journey to the other side of the world. The appearance of foreign workers, speaking little English and wearing dirty clothing was certainly not an image of a good British subject, and it evoked a terrible reputation for all Maltese within Australia. ${ }^{48}$ Because of a lack of government oversight, allowing private individuals like Decesare to manage the migration, the failures to select good laborers and to provide for them on the journey to Australia damaged the Maltese reputation and discouraged other attempts at far-flung Maltese migration for decades.

This lack of a true government-managed emigration department eventually damaged the Maltese reputation in Canada as well. Less than forty years after Decesare's Australian gaffe, Dr.

${ }^{48}$ York discusses this failure in terms of long-term settlement to Australia but also notes that this souring of the Maltese image damages immigration to other nations, particularly those within the Empire, for several decades. Not only do the receiving nations take an ill view of the Maltese but in Malta many look at the failures of the Nudea. York, Empire and Race, Ch. 1. 
Charles Mattei led an ill-fated migration to Canada in the early 1910s. Like the Decesare effort, Mattei personally negotiated and secured from the Canadian government the right to move 250 Maltese migrants to British Columbia in 1912. Canada agreed to this migration with the stipulation that Mattei personally bring the men in a controlled fashion. However, news of the agreement leaked out through Maltese newspapers, another unofficial voice advising emigration. ${ }^{49}$ Hearing of an opportunity to go to Canada, several Maltese men went in advance of Mattei. This hectic and unorganized rush to the west by eager Maltese angered Canadian officials and doomed the experiment, once more damaging the reputation of Maltese as desirable immigrants. ${ }^{50}$ Thanks to the unorganized manner of Maltese preceding Mattei to Canada, those brought under the official program were "coldly received by Canadian immigration officers, who refused entry to seventeen on health grounds." ${ }^{51}$ This abject failure to control the movement of

49 "The [Daily Malta] Chronicle became a de facto 'emigration department', with dozens of prospective emigrants, from villages and towns, presenting themselves at the editor's office to seek advice. It was a ludicrous situation. The vibrant newspaper urged the government to set up an emigration department, and it dismissed the Barron Emigration Committee as 'decrepit'. In the Chronicle's opinion, by 1910 the unofficial emigration committee should have been 'declared non-existent'. Anyone seeking information on emigration prospects in Canada, the United States of America or Australia would tend to rely on the Chronicle, which carried regular reports on the specific labour requirements of such places, as well as general items on such pertinent developments as the 1911 Royal Commission into the New South Wales labour shortage." York, Empire and Race, 38.

${ }^{50}$ W.D. Scott, "Letter to Dr. Mattei from Ottawa," Department of the Interior, Government of Canada Emigration Branch, 30 September 1912, RG 25 B-1-b Vol. 148 F. C8/1, Department of External Affairs fonds, Colonial Office (United Kingdom) - Emigration of Maltese to Canada, Library and Archives Canada, Ottawa, ON, Canada; Mr. Joseph Camilleri and Mr. Vincent Camilleri, interview by Richard Cumbo, Toronto, ON, March 10 \& March 29, 1978, Multicultural Historical Society of Ontario Archives, MAL - 2855 - CAM, Toronto, ON; Mr. Sam Coleiro and Mrs. Carmelo Coleiro, interview by Richard Cumbo, Toronto, ON, March 13, 1978, Multicultural Historical Society of Ontario Archives, MAL-2854-COL, Toronto, ON.

This dissertation is greatly aided by the work of Mr. Richard Cumbo of Toronto, who worked diligently with the Maltese community starting in the 1970s and through to the present. In the late 1970s, Mr. Cumbo conducted several oral histories with Maltese immigrants who came to Canada in the 1910s and 1920s. In particular, two histories, that of Mr. Joseph Camilleri and Mr. Sam Coleiro, discuss coming to Canada in the 1910s. Mr. Coleiro was destined for British Columbia but instead found himself working in northern Quebec during the winter, cutting brush. He quickly left the job and headed for Toronto. Mr. Camilleri came to Toronto in 1913 and found work in the city. These stories will be discussed in greater detail in following chapters.

${ }^{51}$ Internal memos from the Department of the Interior suggest that Port Officials should make sure examinations on those coming ahead of Dr. Mattei should be "very strict and all undesirable or unfit parties rejected." Ibid., 43; W.D. Scott, "Internal Memo," Department of the Interior, Government of Canada - Emigration Branch, 26 May 1913, RG 25 B-1-b Vol. 148 F. C8/1, Department of External Affairs fonds, Colonial Office (United Kingdom) - Emigration of Maltese to Canada, Library and Archives Canada, Ottawa, ON. 
Maltese once again created a hostile view of the Maltese as poor British subjects, hampering efforts to enter Canada well into the 1920s when the need would be at its most pressing.

A lack of long term planning, and the fleecing of Maltese migrants in some cases by these private officials, not only damaged a carefully emerging British Maltese identity but also the colonial government's treasury. The problem with many of these schemes to send Maltese abroad revolved around the private nature of the scheme. One proposal in 1910 to establish an agricultural colony in Australia was met with rejection. An official warning noted that although the leader "appears to be a man of some intelligence," he "is not reliable in money matters, and that his object is probably to make money in irregular ways out of intending emigrants. ${ }^{" 52}$ No doubt this was not the only case of a private citizen hoping to make money from the enterprise. Because of such efforts a more permanent solution was needed to handle the increasing problem of emigration to both protect the emigrant from scheming men and protect the government from paying for those failed schemes. Governor Leslie Rundle lamented in 1910 that, ...cases occur of a man selling his furniture to emigrate, failing to establish himself abroad, and being returned destitute, at the expense of the Colony, in a worse state than before. This misdirected emigration might be avoided, or, at all events, the number of failures might be diminished, were some well-considered scheme devised. ${ }^{53}$

It is at this moment in the early 1910s that the colonial and British governments realized the importance of an official emigration commission for the smooth release of Malta's excess population. The establishment of an official Emigration Department brought its own problems.

In 1912, a Royal Commission on Malta exploring the finances and economic position of the

\footnotetext{
${ }^{52}$ Leslie Rundle, "Correspondence Relating to Emigration From Malta, The GOVERNOR to the SECRETARY OF STATE” 22 November 1910. CO 883/7/12, Colonial Office Records, The National Archives United Kingdom, Kew, England, 8-9.

${ }_{53}$ Leslie Rundle, "Correspondence Relating to Emigration From Malta, The GOVERNOR to the SECRETARY OF STATE" 5 August 1910. CO 883/7/12, Colonial Office Records, The National Archives - United Kingdom, Kew, England, 4.
} 
colony made an official statement agreeing with Governor Rundle's statement claiming,

"systematic emigration on a large scale is the most important of the objects which the

Government of Malta must set itself to attain." ${ }^{, 54}$

By 1921, with the Emigration Department fully operational and attempting to control the

flow of Maltese migrants, a large exodus of these educated and skilled laborers was underway.

With the massive layoff in the Royal Dockyards following World War I, Maltese skilled labor

fled the island in droves looking for employment, chiefly in Detroit. Although numerically in

terms of raw population leaving the immigration was embraced, this movement was half-

heartedly accepted by officials in Malta. In candid statements, Rear Admiral Brian Barttelot

remarked that the laborers "claim that they are not receiving their market values [in Malta] which

is obviously the truth," and further that the only way to retain the skilled labor was to give raises

otherwise it would vanish to the United States. ${ }^{55}$ Similarly, Joseph Howard, head of the

Emigration Commission, wrote to Governor Herbert Plumer saying, "in the present state of

labour in these islands it would be unfair to stop this outlet..." ${ }^{" 56}$ Perhaps lamenting the waste of

resources expended to educate and train these young Maltese laborers, both Howard and Plumer

\footnotetext{
${ }^{54}$ Huw R. Jones, "Modern Emigration from Malta," Transactions of the Institute of British Geographers, no. 60 (November 1973), 102.

55 Brian Barttelot, "Rear Admiral Barttelot to SECRETARY OF STATE, Malta," 31 March 1920. To Secretary of State, Piece No. 94, Malta National Archives, Rabat, Malta. What the Rear Admiral fails to mention is that the men are not simply shopping their talents around the world, but generally laid off skilled labor. The Malta Herald writes in 1920, "With our fleet in the Mediterranean more powerful than it has been for years past, it would appear to be obvious that Malta Dockyard must be kept in an efficient state at all costs. Yet the Admiralty started discharging skilled men at the first opportunity, apparently forgetting that Malta is an island and does not contain a dozen shipyards. The result is obvious: the men preferred emigration to America to starvation, and the Americans were very glad to pay big money for skilled labour of this sort. Now the discharges have been stopped and every effort is being made to discourage men leaving voluntarily. But the damage has been done, and, attracted by the reports of their relatives in the States, men are leaving in shoals." Carl R Loop, "Emigration from Malta to the United States," Malta to the Department of State, 10 April 1920, 849B.56/4, RG 59, Records of the Department of State, NARA II, College Park, MD, 1.

${ }^{56}$ Joseph Howard, "Memorandum on Emigration to the United States of America," 22 March 1920. To Secretary of State, Piece No. 88, Malta National Archives, Rabat, Malta.
} 
decried how "deplorable [it is] that while they are welcomed in the United States, they should be lost to the Empire owing to the attitudes of the Governments of Canada and Australia." 57

The massive loss of skilled labor in Malta, critical to the smooth operation of the Royal Dockyards, was the final straw for the imperial government. What had traditionally been a Maltese problem - emigration - now became a full-fledged imperial issue as well. The creation of an emigration department became a necessary step for both governments within the diarchy. But even with the full weight of Imperial politics behind the Maltese migration schemes, some issues would not completely disappear. The now firmly established question of how to give up imperial control and assert it at the same time became even more complex in the 1920s. As both the imperial government and the Maltese government attempted to cooperate on the issue of emigration, issues like payment for migration, and where Maltese men could proceed emerged. With more direct government control over emigration there developed a long term hope for better regulation and potentially more doors open to the Maltese migrant. ${ }^{58}$ In order to achieve long term success of migrants, and thus prevent return migration, Maltese and British officials swallowed the bitter pill of sending some of the more educated and trained individuals. The thought remained that despite the brain drain and loss of skilled labor in Malta, these educated and trained individuals could qualify to enter North American nations despite immigration

\footnotetext{
${ }^{57}$ Herbert Plumer, "The GOVERNOR to the SECRETARY OF STATE," 22 March 1920. To Secretary of State, Piece No. 88, Malta National Archives, Rabat, Malta.

${ }^{58}$ York, Empire and Race, 101. Henry Casolani was appointed director of the Maltese Emigration Department and ran a rigid outfit. Casolani sought to improve the quality of migrant sent abroad under officially sanctioned movements to nations expecting the incoming Maltese. His greatest achievement, the limiting of unqualified and inept migrants from leaving the Maltese shores and thus ruining Malta's reputation as a source of labor. The numbers of men rejected during the 1920s runs as high as a third of all applicants. Only 27,000 men achieved their passports out of 40,000 prospects over a six-year period between 1920 and 1926. This type of selectivity in creating a new Maltese migrant, helped to recreate the image of Maltese labor. York calls Casolani's "far-sightedness, professionalism, and mastery of what he regarded as 'the science of emigration' [which] enabled progress to be attained. His vision was of an emigration department that was 'first class and well equipped' because, to him, 'scientific and expensive emigration is the one and only remedy, if a disastrous crisis now, or in the immediate future, is to be avoided."”
} 
restriction, and therefore it was necessary to encourage their migration in order to save Malta from overpopulation and economic collapse. By striving to achieve this, the Maltese who went abroad after 1920 did so with much greater success than their predecessors, finally establishing footholds in nations that would allow for future emigration.

Overall, the British and the Maltese made massive strides in recreating a Malta and Maltese identity that was both contemporary and British. The economic retooling of the islands, a drive for general education and skills training to serve the Royal Navy in the $20^{\text {th }}$ century, significant health improvements, and the development of a political identity for the Maltese catapulted the islands from an important but underdeveloped port to a stabilizing and increasingly European nation. As this chapter discussed, the transformation was not easy either domestically, imperially, for those Maltese abroad prior to the 1920s. In addition, life in Malta did not magically transform into a wonderfully peaceful and prosperous existence. Rather the growth of domestic Maltese politics, and the nearly self-governing style of colony that Malta became, brought a totally new political issue to be dealt with in the coming decades. What did change for the people of Malta over the course of the next four decades was a slow but increasing foreign acceptance, and in some cases a desire for, Maltese laborers trained by the British, speaking English, and in all practical cases good British subjects. 


\title{
Chapter 3 - Shutting North America's Doors
}

\author{
"...The great lands of the Empire are crying for souls." 1 \\ Henry Casolani, Superintendent of Emigration - Malta, 1923
}

One of the most striking traits of North America is the incredible closeness exhibited

between the United States and Canada both at a political and social level. This interconnected mingling has existed for the entirety of the Euro-American history on the North American continent. Even today, the United States and Canada today share the longest undefended border in the world. Though the path towards this peaceful co-existence at times exhibited more of a sibling-type hostile relationship than current neighborly goodwill, most, if not all, of these hostilities focused on the shaping of the border. As each nation marched down the path of federalization in the late nineteenth century, unsurprisingly both began to craft policies that followed a similar trajectory. ${ }^{2}$ One of the most important policies was that of immigration law. In both countries immigration law reflected racial and economic theories of the era. With similar laws regulating the flow of people into each nation, they turned their attentions towards a collective "Golden Door" on the shores of the Atlantic and Pacific. Although differences did emerge between immigration policies in the United States and Canada, when viewed over a long

\footnotetext{
${ }^{1}$ Henry Casolani, Report on Emigration, For the Fiscal Year 1922-1923. Malta: Government Emigration Office, 11 October 1923, Document attached to Consul Mason Mitchell to Malta to the Department of State, 27 October 1923, 849B.56/14, RG 59, Records of the Department of State, NARA II, College Park, MD, p. 4.

${ }^{2}$ Angelika Sauer and Catherine O’Donnell, "1867 and all that..." in Migrants and Migrations in Modern North America by Dirk Hoerder and Nora Faires, (Durham, NC: Duke University Press, 2011). Sauer and O'Donnell argue that for Canada, the year 1867 represents the year of Confederation, incorporating Lower (Quebec), Upper (Ontario) Canada, and British Columbia into a confederated single government. Steps from here continue to consolidate Canada's hold on the Prairies on the Maritimes. For the United States, by 1867 the Civil War was clearly passed and Reconstruction had begun in earnest. The US government would continue to exert federal control on domestic policy and as the century came to a close, the government began to look outwards transforming into an imperial power. Sauer and O'Donnell, writing to convince the audience of history professors to begin teaching North American history courses beginning in 1867 as it marks a turning point in Canada, the US, and Mexico. Not only does this argument carry weight in terms of federalization and independent, democratic institutions in North America but one can also trace how law and policy develops in synchrony from that date forward. For further reading see also; Michael M. Brescia and John C. Super, North America: An Introduction (Toronto: University of Toronto Press, 2009).
} 
duration it becomes clear that the policies closely reflected one another. Those people barred from entry in one were eventually barred from the other as well, and once admitted to either nation the passage between the two was relatively easy and allowed labor to move quickly over the interior border. It is only recently, with the passing of the Western Hemisphere Travel Initiative (WHTI) in 2009, that the interior border has faced any real scrutiny. ${ }^{3}$

This chapter attempts to understand how immigration policies developed in such a complimentary manner. While Maltese identity was reshaped under British rule in the $19^{\text {th }}$ and early $20^{\text {th }}$ century, the same time period witnessed North American policies driven by new complications of identity on the continent. As each nation marched westward, conflict and industry recreated national frameworks of identity. The first part of the chapter will deal with the great industrial and societal push into the continental west. As the chapter develops, it will specifically highlight how growing imperial functions in both nations drew in millions of migrants. These influxes of labor actively shaped racial understandings and ultimately racially based exclusions. Finally, the chapter explores how the Maltese began to test these policies beginning in the 1910s and 1920s. This prodding of immigration laws opened small crevices of differences that explain, despite many similarities, the intensely important divergences that existed. Particularly in the case of the Maltese, the movement of this very small population of people, no more than ten thousand by 1928, illustrated how politics and identity crept into the construction of immigration policy in North America. ${ }^{4}$

\footnotetext{
${ }^{3}$ Nora Faires, "Population Movements and the Making of Canada-U.S. Not-So-Foreign-Relations," in Migrants and Migrations in Modern North America by Dirk Hoerder and Nora Faires, (Durham, NC: Duke University Press, 2011), 140, 130. The WHTI has forced a "Mexicanization" as Faires puts it of the Canadian-US border. No longer is it referred to official as the longest undefended border in the world but rather the "longest secure border in the world." This is in drastic contrast to the Post-World War II era when the US War Department claimed that "for generation after generation, from Atlantic to Pacific, people have moved freely across the Canadian American border."

${ }^{4}$ F.C. Blair, "Memorandum to Mr. Cullen," Department of Immigration and Colonization, Ottawa, Canada. 21 March 1928. Canadian National Archives: Ottawa, Canada. RG 25 A-3-a Vol 1327 F. 1090/22 - 610747.
} 


\section{Closing the Gate}

The bonds of kinship between Canada and the United States are often overlooked or simply taken for granted by its citizens, particularly those in America. While differences certainly exist between the two nations, the similarities in the collective histories of the two are hard to ignore. ${ }^{5}$ As former British colonies, the common lineage suggests a shared outlook on development, politics, and economies. This common political ancestry unites the upper two thirds of the North American continent in more ways than we generally imagine. The closeness of the two remained so tight that shortly after the American Revolution provisions to bring the Canadian colonies into the United States continued to exist, should those colonies ever seek a more complete union. ${ }^{6}$ What ultimately doomed a unified Anglo-North American nation was the failure to capture and force Canada into the United States during the War of 1812. The result of the war launched for the first time a "Canadian" identity and more importantly, secured British North American, later Canadian, independence from American domination. ${ }^{7}$ Despite a settled international border that would not be challenged in any meaningful way, the two nations eventually began to develop in ways that would make it difficult to see major differences. This

${ }^{5}$ Fairies, "Population Movements and the Making of Canada-US Not-So-Foreign Relations," 135-137. Fairies chapter explores how the two nations have developed a historical and cultural connection across the borders and today into places like Florida and Arizona where "snowbirds" find escape from the blustery Canadian winter. But while the focus in Canada is on the United States, particularly forming an identity that is actively attempting to separate itself from America, the majority of American citizens think little about Canada except those on the border who work, play, and share familial ties with Canadians.

${ }^{6}$ Jeffers Lennox, "A Northern Chorus: The Canadian Turn in Early American History," on Borealia: A Group Blog on Early Canadian History, (accessed, 11/23/16) https://earlycanadianhistory.ca/2016/03/21/a-northernchorus-the-canadian-turn-in-early-american-history/

${ }^{7}$ The concept of Canadian identity is complex. Many historians, sociologists, political scientists, and general social commentators suggest that the struggle to define a truly independent and distinctive Canadian identity is the only tell-tale sign of that identity. Nationalism struggles to exist in the former Dominion. Although, much of this hints that more recent decades have seen a change in this attitude. Canadian identity is still, even today, often formulated in simultaneous opposition and similarity to Americans. Those in Canada today looking for a national epic often see the War of 1812 as the defining moment. The Government of Canada in 2012 released several advertisements calling it the fight for Canada, and the birth of Canada. 
becomes quite evident if one looks at the settlement of western territories and the introduction of industrial capitalism in the latter half of the nineteenth century.

Starting in 1867 , the historical trajectory of the United States and Canada aligned more closely than ever before. The growth of federal power at the national level in 1867 enveloped the two countries in a completely new manner. For the United States, the end of the Civil War in 1865 led to Reconstruction, the attempt to not only bring the southern states back into the union but to also reshape post-war, post-slavery society. The passing of the $13^{\text {th }}, 14^{\text {th }}$, and $15^{\text {th }}$ amendments, the great reshaping of American citizenship and voting privileges, accompanied the first ever national tax system. These radical new concepts introduced "new relationship[s] between government and citizens," and most importantly a greater concentration of power in Washington than ever before. ${ }^{8}$ While this intensive restructuring was occurring in the United States, Canada also experienced a celebrated moment of great change, Confederation. A movement to create an independent Dominion within the British Empire had been afoot for several years and in 1867, with the passing of the British North America Act, Canada was granted self-rule and confederation was achieved. Tying together the provinces of Canada, Nova Scotia, and New Brunswick, the nation of Canada was born. These moments of rapidly increasing federalization across the continent mark 1867 as a prime starting point for any analysis of the two nations in tandem.

As a newly confederated nation in 1867 , the Canadian government immediately sprang into action to push for a plan to populate its western regions. The new nation, led by Sir John A. Macdonald's government, felt rising pressure to build a transcontinental nation in order to best

\footnotetext{
${ }^{8}$ Heather Cox Richardson, West from Appomattox: The Reconstruction of American After the Civil War (New Haven: Yale University Press, 2007), 3. Cox writes that the Thirteenth Amendment was "the first amendment in the history of the American Constitution that increased, rather than limited, the power of the national government."
} 
compete with the United States. By 1869 the first transcontinental railroad in the United States was completed, and the flood of Americans to the west would only increase. Further, the desire to bring British Columbia into the Confederation drove much of the Canadian federal government's actions. Ottawa was finally able to convince British Columbia to join Confederation in 1871 under promises of connection to the east. Considering the increasingly imperialistic actions of the United States, the race to settle the west sparked national ambitions in Canada. ${ }^{9}$ The unification of Canada's Pacific and Atlantic provinces relied upon the construction of the Canadian Pacific Railway (CPR), built almost two decades after the first transcontinental railroad in the United States. Simultaneously, the success of the railroad staked a claim on the Canadian interior and opened the Canadian prairies for migrants. Without the CPR running through the vast interior, Canada's claim on the western territories would have been in a precarious position faced with the ever-expanding American territorial grabs. Imposing federal control on this vast transcontinental prairie presented not just logistical challenges but additionally raised questions of just how inclusive the United States and Canada would become.

During the mid-nineteenth century, the race westward into the interior of the continent radically changed both countries. At times labelled the "dynamic of concealment," the movement to the west in postcolonial North America papered over the dichotomies that formed each nation. In the United States, that dichotomy hinged on the whiteness of the nation, hiding from view its African slave past, histories of native peoples, and non-protestant religions. ${ }^{10}$ The push to settle

\footnotetext{
${ }^{9}$ Valerie Knowles, Strangers at Our Gate: Canadian Immigration and Immigration Policy, 1540-2006 (Toronto: Dundurn Press), 68.

${ }^{10}$ Jennifer Reid, Louis Riel and the Creation of Modern Canada: Mythic Discourse and the Postcolonial State (Albuquerque: University of New Mexico Press, 2008), 7. Reid quotes historian of religion Charles Long on the topic of concealment saying "the actual relationships and entanglements of cultures that took place during the imperial and colonial ventures' of the modern period, a stylistic that has too often obscured 'the gross realities of economic exploitation, tyrannical practices, terrorization, and enslavements.' In the United States, for instance, the discursive - and dichotomous - formulation of the nation as "white" has concealed the foundational meaning of slavery and conquest. As we will see, the dichotomy of color has undoubtedly figured also in the conceptions of
} 
the newly won west, wrested from the hands of Mexico, forced Americans to deal with the question of slavery's role in the nation. Should slavery be allowed to expand west with the nation, or be confined to the deep south? This question became one of the major touchpoints leading to the American Civil War. The nation descended into a nearly five-year long conflict, consuming the majority of the federal government's attention. Yet, even with conflict raging, the settlement of the west was still a major objective of the government. The concealment of nonwhite Americans in the national narrative required constant social and governmental attention.

During the American Civil War, westward expansion continued in all its forms, including federal attempts to clear the land of any native presence and replace it with white settlers. One of the most iconic pieces of western settlement legislation, the Homestead Act, was signed into law by Abraham Lincoln in 1862. Encouraging the settlement of the west, the Act gave homesteaders an opportunity to settle government land for a small fee. By 1900, eighty million acres of public land was settled in the west through the program. ${ }^{11}$ Much of this land was settled by a boom of northern European migrants, particularly in the northern states like Minnesota and the Dakotas were thousands of Swedes, Danes, and Finns were enticed by the offers of free land. ${ }^{12}$ In order to keep peace on the newly settled plains, the physical clearing of the west during the $1860 \mathrm{~s}$ became part and parcel of the American Civil War "borderlands" campaign. Massacres of Native peoples turned into a terrible common occurrence over the following decades. ${ }^{13}$ These clashes

\footnotetext{
Canada, particularly in terms of a long-held view of the state as a northern European outpost. This concealment has been imbedded in the discursive, political, and economic history of the country."

${ }^{11}$ Potter, Lee Ann and Wynell Schamel. "The Homestead Act of 1862." Social Education 61, no. 6 (October 1997): 359-364. https://www.archives.gov/education/lessons/homestead-act.

12 John S. Lindberg, The Background of Swedish Emigration to the United States: An Economic and Sociological Study in the Dynamics of Migrations (Minneapolis: University of Minnesota Press, 1930). Scandinavian immigrants, particularly Finns and Swedes, also populated much of the Canadian West at the same time. For more see, Michel S. Beaulieu, David K. Ratz, and Ronald N. Harpelle, eds. Hard Work Conquers All: Building the Finnish Community in Canada (Vancouver: UBC Press, 2018).

${ }^{13}$ Euro-American and Native clashes occurred across the frontier during the Civil War, including places like Minnesota where the Sioux and Minnesotans clashed during 1862. The Bear River Massacre in 1863 also
} 
between white immigrants, the federal government, and native peoples continued in the West despite the war in the East consuming much of the governments attention. ${ }^{14}$

The interaction of Americans on the western frontier actively shaped a national identity built on a specific Anglo-American heritage and industry that concealed the contributions of native peoples and Asian or Latin migrants. The destruction of native land claims, and the forced removal of indigenous people from their homelands continued a pattern of centuries old colonization by Euro-American governments. The forced removal of native peoples - especially in the case of the Comanche, Lakota, and Sioux, people who at times exerted their own imperial projects upon the western plains - was ultimately accomplished through the immense resources, manpower, and weaponry of the U.S. military which not only cleared the way for settlement but also furthered the creation of an industrious, white-only nation. ${ }^{15}$ At the same time as the Plains Indians Wars, Californians began to push for the exclusion of the very people who helped to build the routes to the west, the Chinese and later even the Japanese. In Arizona, vigilantes enforced a strict racial divide, stealing white - largely Irish Catholic - orphans from the homes of Mexican workers to be raised by white protestant families or sent back East. ${ }^{16}$ These exclusions of non-protestant, non-white individuals exhibited a federal, economic, and social policy of white control and white-only settlement.

preceded the Sand Creek Massacre. All of these conflicts exhibit a continual push westward even during the grips of Civil War by the United States. Alvin M. Josephy, The Civil War in the American West (New York: Alfred A. Knopf, 1991).

${ }^{14}$ Ari Kelman, A Misplaced Massacre: Struggling over the Memory of Sand Creek (Cambridge: Harvard University Press, 2013), 9-10. Sand Creek Massacre National Historic Site, "History \& Culture," National Park Service, https://www.nps.gov/sand/learn/historyculture/index.htm.

${ }^{15}$ Pekka Hämäläinen, The Comanche Empire (New Haven, CT: Yale University Press, 2008), 3-6. Hämäläinen makes the claim that the Comanche transformed in the $18^{\text {th }}$ and $19^{\text {th }}$ century into an empire, controlling the vast southwest. This claim has been challenged, but for this work, it makes the point clear that the conquering of the west by Euro-Americans was not an easy, quick, or cheap task.

${ }^{16}$ Linda Gordon, The Great Arizona Orphan Abduction (Cambridge: Harvard University Press, 1999). 
The attempt to establish federal control in the Canadian prairies represented an even greater challenge. Not only was the Confederation young, but the thin population struggled to supply the necessary force, military or political, needed to open territory for expansion.

Frustrating this federal control was the presence of the Métis people, a native group of mixed European and Indigenous heritage, in the Canadian prairies. Led by Louis Riel, the Métis were a complicated population who internally struggled to strike a balance between self-government and the idea of government being established under Anglo-Canadian authority in the region. ${ }^{17}$ Unlike the United States, in Canada there did not exist such a clear dichotomy of skin tone and religion. The inclusion of Quebec and French-Catholics into the nation from the very start meant a nation built on plurality. Confronting the Métis - a partially French, partially Catholic populace - in the west challenged this very plurality and the foundations of Canada as a new nation. Twice the Métis under Riel played a major role in the fight against the establishment of western provinces, leading the Red River Rebellion in Manitoba in 1868 and the North-West Rebellion in Saskatchewan in 1885 . These rebellions gave Riel a reputation as a "man who called an emerging state to recognize the defining meaning of plurality at its foundation." 18 The combination of both rebellions cost the Canadian government not only time but money, deploying 8,000 troops and spending over $\$ 5$ million. ${ }^{19}$ Despite the cost, neither rebellion ended in large scale warfare, although Riel was executed for his role. What they both represent was the

${ }^{17}$ Gerhard J. Ens, Homeland to Hinterland: The Changing World of the Red River Metis in the Nineteeth Century (Toronto: University of Toronto Press, 1996), 128. Ens argues that the Metis rebellion was an incredibly complex socio-economic issue within the Metis community, dividing the people between the Anglo-Metis and the Franco-Metis. The French descendant Metis tended to be those who had the greater economic status and therefore the most likely to lose under Canadian control, while the Anglo-Metis saw much benefit to the incorporation of the Red River Colony into Canada.

${ }^{18}$ Ried, Louis Riel and the Creation of Modern Canada, 8.

${ }^{19}$ James Belich, Replenishing the Earth: The Settler Revolution and the rise of the Anglo-World, 17831939 (Oxford: Oxford University Press, 2009), 407. 
tenuous hold the Canadian government had on both its western provinces as they began to form, and its national identity. ${ }^{20}$

The slow but steady implementation of federal control and settlement across the great North American prairies opened the door to economic development. But the hardscrabble business of trans-national railways, development of mining companies, and large corporate farms required massive amounts of labor, more than a settler population. The rush to find new labor to fill the gap was answered largely by private companies and labor contractors. It remained the government's prerogative initially only to regulate those entering North America. Once these two nations stretched fully to the west the possibility of Atlantic and Pacific trade was too enticing to turn away from, further fueling economic growth. While the United States pushed its national reach outwards in terms of imperialism far more aggressively than Canada, both nations rooted their economic policy firmly in the growing democratic-capitalism spurred by the industrial revolution. With the west opened for economic exploitation and settlement, both the United States and Canada allowed corporations to lead the way forward.

In the United States, the west was developed mostly by industrialists and financers from the East and Great Britain. In the last half of the $19^{\text {th }}$ century, over five hundred British companies formed to invest in western mining, pouring capital into the remote West. ${ }^{21}$ Investment dollars also came from American titans of industry like Daniel J. Guggenheim, who constructed a massive mining complex in Utah bringing the industrial world to the west, or

${ }^{20}$ As an aside, this moment in time creates two of the last icons of the North American nations. In the United States the push westwards births the "Wild West Show" which travelled the world to much acclaim and furthered the iconography of the American West as the white cowboy, white US Cavalry and the red Native Brave. The iconic Canadian image of the "Mountie" also comes from this era. Needing to create a mobile police force capable of enforcing the new nations laws and regulation in the vast western territory, the mounted police in their memorable bright red uniforms were created.

${ }^{21}$ Belich, Replenishing the Earth, 421. Belich describes the British mining joint-stock companies as largely failures, writing that only one in nine "ever paid any dividends." Further "many promoters found it was far more profitable to mine investors than to mine ore." 
Andrew Carnegie who poured money into the Pullman Palace Car Company in 1867 to develop sleeper cars, making the journey west comfortable. ${ }^{22}$ These booming companies operated on the backs of a muddled and emerging system of free-wage labor, struggling to redefine the contract between labor and boss. As men like Samuel Gompers emerged to fight for the rights of those free wage laborers, other men, padrones like Antonio Cordasco, began to exploit the movement of nominally-free contract immigrant labor. ${ }^{23}$ Using padrones or labor contractors, imported ethnic labor generally was sent westward to those companies hoping to capitalize on the vast resources. The padrones were able to bring in large quantities of cheap, easily controlled labor that corporations craved to remote work sites. These labor contractors often skirted the law, bringing in workers, profiting from their wages, and then controlling every movement of those laborers once in North America.

The operation of western mines and construction of railroads on the backs of immigrant labor took similar paths on both sides of the border. The major employer in the Canadian west, the Canadian Pacific Railroad (CPR) drove the greatest amount of immigration to that nation in the late $19^{\text {th }}$ century. The CPR was not the only western corporation or scheme to develop the prairies in Canada, but it was the most successful and more importantly the most well-known. The federal government took steps to ensure its growth with homesteading legislation and what some of have called "corporate colonization" attempts, allowing major corporations like the CPR to run its own colonization schemes in the Canadian west. ${ }^{24}$ These ventures did not come cheap

\footnotetext{
${ }^{22}$ Gunther Peck, Reinventing Free Labor: Padrones and Immigrant Workers in the North American West, 1880-1930 (Cambridge: Cambridge University Press, 2000), 49. Richardson, West from Appomattox, 80.

${ }^{23}$ Ibid., 49. "...immigrant men who toiled at the bottom of the open pit with no instruments but their arms and backs, paying job fees and tributes to their padrones in a system that seemed as old and timeless as the pyramids... Most onlookers were thus befuddled by their discovery. Put simply, how could padronism be thriving at the most modern mining operation in North America?"

${ }^{24}$ Belich, Replenishing the Earth, 406.
} 
however, as they were heavily subsidized by the government to the tune of $\$ 85$ million. ${ }^{25}$ The CPR exhibited many familiar traits, and much like its fellow rail companies to the south, the insatiable need for labor in remote regions of the continent forced the company to look outward to continue its operations. To solve the labor question, the rail company brought in waves of Chinese labor in the late $19^{\text {th }}$ century - a vast majority of whom previously on worked the U.S. transcontinental railway - and later in the $20^{\text {th }}$ century, Italian labor. Again, in similar fashion to western American corporations, the CPR relied heavily on padrone figures to supply a labor force. Their reliance was so heavy that Antonio Cordasco, the Italian padrone, was given an office in Montreal at the CPR main building. ${ }^{26}$ These types of "officials" and the labor they brought into the country was almost exclusively transient, not the type of labor that would settle the vast western territories.

With transient labor brought westward by corporations and padrones, the lack of settled population along the Canadian prairies produced a bleak economic outlook. The only way to ensure the economic productivity, and exclusive Canadian control of the prairies was to have a "populous West under the plough." 27 In order to achieve "large-scale immigration into that sparsely settled plain" the government under Macdonald and successive governments until World War I focused on importing farmers, agriculturalists and domestic help from Britain, the United States, and Northern Europe. ${ }^{28}$ The Canadian Ministry of the Interior viewed western

${ }^{25}$ Belich, Replenishing the Earth, 406.

${ }^{26}$ Peck, Reinventing Free Labor, 60.

${ }^{27}$ Knowles, Strangers at our Gates, 73. “...the creation of the 'Postage Stamp Province' of Manitoba the following year [1870]; and British Columbia's entry into Confederation in 1871 with the promise of a transcontinental railway threw the whole question of immigration into sharp focus, for now there were vast new areas to be settled. Indeed, only a populous West under the plough would ensure the economic viability of the projected transcontinental railway and safeguard the forty-ninth parallel against encroachment from Canada's rapacious neighbor, where at least one state legislature (Minnesota) had cast covetous eyes on the Red River district."

\footnotetext{
${ }^{28}$ Knowles, Strangers at our Gates, 69.
} 
settlement and development as colonization, perhaps Canada's great imperial project, and because of this it remained one of the chief tasks assigned to the Ministry. ${ }^{29}$ The story in the United States at the turn of the century was the opposite. As Canada struggled to fill its western prairies, Fredrick Jackson Turner began to ponder the impact of the closing of the American frontier on the American democratic system. ${ }^{30}$ Although labor continued to stream into the west; included among them thousands of Canadians, the U.S. Census bureau official marked the frontier as relegated to history. This massive movement west in the United States, and the smaller movement west in Canada, was just part of a complete industrial transformation of the two nations.

As corporations and populations moved into the west, the fruits of their labors began to move eastward. Each step west created boom towns in the region, and as raw materials flowed east, industrialization of cities in the Midwest and the Northeast exploded. Commanding a vast rail network into its hinterlands of Wisconsin, Minnesota, Iowa and beyond, Chicago transformed into the industrial gateway of the west. Lumber, livestock, and grains flowed east into the city and Chicago's capital flowed back out to finance those far-flung operations. ${ }^{31}$ Chicago's boom, along with some minor growth in cities like Minneapolis, St. Louis, Cincinnati, and Detroit was later accompanied by a similar industrialization in both Toronto and Montreal,

\footnotetext{
${ }^{29}$ Belich, Replenishing the Earth, 406.

${ }^{30}$ Knowles, Strangers at our Gates, 89; Belich, Replenishing the Earth, 408, 411. Writing about Turner and his Frontier Thesis, Knowles argues, “... if there was a 'psychological closing' of the frontier in the United States, there was both a 'psychological' and a 'material opening' of the frontier in Canada. In a sense the frontier had merely shifted northward to the Canadian prairies." Knowles is not alone in making this statement. Belich also writes that "Canada's Hour" was sparked by external forces stating, " "The pull of the colossal US economy delayed Canadian economic development'...the American West attracted far more British migrants and money than did Canada, and to add insult to injury drew in substantial numbers of Canadians as well." But by 1900 the "...US development was such that it no longer needed a supplementary British oldland to finance and people its booming west. British money and migrants went instead to Canada. Indeed, America in the 1900s now had the spare capacity to supplement British inputs into Western Canada, hence the inflow of 600,000 American settlers and their money."

${ }^{31}$ See William Cronon, Nature's Metropolis: Chicago and the Great West (New York: W.W. Norton \& Company, 1991).
} 
taking advantage of the railways into the city and the capital they could expend in the west. The extractive industries established in places like Utah, Nevada, Washington, Oregon, British Columbia, and Alberta were almost exclusively financed by east coast investors. ${ }^{32}$ The continental west essentially was financially and industrially colonized by the continental east. ${ }^{33}$ By 1880 the powerful draw of capitalism, as described above, in both the United States and Canada encapsulated the two major North American nations in a singular economic unit. In economic terms, national boundaries between the United States and Canada began to melt away at the turn of the century as the two economies began to "interpenetrate" through what was called the "logical result of the geography of Canada and the United States." 34 The transcontinental transfer of goods and money east to west, from the Pacific to the Atlantic brought with it a need for new migrants who dominated the landscape. Asian migrants flooded the west coast working the railways, farms, and mines from California to British Columbia. Labor from Mexico moved into the southwest and even into the Midwest to work seasonally in the agricultural heartlands. In the great cities of the east coast, from Chicago to Toronto, New York to Montreal, industrialization required imported labor to fill the factories. Answering the call of the east coast

32 Belich, Replenishing the Earth, 401. Belich quotes several "western and US historians" who take the view that the west coast was largely an economic colony of the east writing, "Multiple trunk rail systems, plus great steamships and the Panama Canal, created not one but two virtual bridges. Wheat, lumber, and fruit flowed one way, and even large capital goods could flow the other. Pacific Northwestern rail-wagon factories became 'practically only repair shops', the percentage of workers in manufacturing actually dropped, while the lumber industry was 'increasingly under outside control'... The Pacific Northwest was an 'extreme case of economic dependence'. Yet locally, when times were good, 'there was little apparent hostility to eastern exploitation of our natural resources.' Washington State may have been a province of New York, as New Zealand was a far-flung province of London, but in neither case, despite a few dissenting voices, did the locals seem to mind."

${ }^{33}$ Serge Courville, "Part of the British Empire, Too: French Canada and Colonizing Propaganda," in Phillip Buckner and R. Douglas Francis, eds., Canada and the British World: Culture, Migration, and Identity (Vancouver: UBC Press, 2006), 138-139. Courville discusses how this attitude of "internal colonization" swept across the British colonies, and included the United States with minor modifications. He notes that this was not always a push westward, but in the case of Quebec, a push to create internal colonies in the northern reaches of the province.

Looking at propaganda for immigration, Courville, suggests that northern Quebec became the "manifest destiny" of the province and echoed the colonization of the American and Canadian west's by the Anglo populations of those nations.

$$
{ }^{34} \text { Ibid., } 415 .
$$


were millions of migrants uprooted from their European homelands. From coast to coast, North America was awash with migrants. The new economy emerging across the continent required skilled and unskilled laborers at a rate never seen before. ${ }^{35}$ As each nation took their imperial turn, America focusing overseas and Canada on the conquering of its west, the need to create a stable identity out of the mangled host of new migrants took hold.

\section{The Continental Market for Labor}

The incredible growth of industrial might demanded both a global market and global workforce. Much of the global workforce gobbled up by industrial power in the Americas was part of a transient labor system that encompassed the globe. ${ }^{36}$ Thanks to the massive growth of industrial power the capitalist system dominated both North America and Europe. This domination led to the formation of a vast hinterland comprising the remainder of the globe, a hinterland "pulled and transformed by the social and economic vortex of the industrializing center." ${ }^{37}$ Increasingly the need to supply these growing industries outweighed national boundaries. The operation of padrones from Mexico through to Canada tended to circumvent national boundaries in order to move labor to its destination. Those laborers were often more than willing to move vast distances to secure employment. The growth of international capitalism meant a laborer from Italy or Greece could now include North America into a seasonal labor pattern. It was the padrone figures, aided by increasingly fast and reliable transit, that provided the expertise to move across national and continental boundaries. ${ }^{38}$ The boom of

${ }^{35}$ Richardson, West from Appomattox, 80.

${ }^{36}$ Peck, Reinventing Free Labor, 5.

${ }^{37}$ Matthew Frye Jacobson, Barbarian Virtues: The United States Encounters Foreign Peoples At Home and Abroad, 1876-1917 (New York: Hill and Wang, 2000), 60. He pulls the main theory of a vast industrial core stretching across the Atlantic from Europe to North America from the works of David Montgomery. Jacobson writes this that industrial core stretched from "Chicago and St. Louis in the west; by Toronto, Glasgow, and Berlin in the north; by Warsaw, Lodz and Budapest in the east; and by Milan, Barcelona, and Louisville in the South."

${ }_{38}$ Peck, 5. Walter Nugent, Crossings: The Great Transatlantic Migrations, 1870-1914 (Bloomington: Indiana University Press, 1992), 31. Nugent writes that transatlantic migration "leaped forward after 1870 when 
capitalism and free wage labor greatly changed the type of working class found in North

America.

Not only did this industrialization change the pattern of migration towards the industrial core, but it also created, particularly in North America, nations increasingly reliant on foreigners. In America, manufacturers relied on foreign populations to both produce the goods in the United States cheaply and to consume the wares in their homelands. The feeling grew so intense that Commander Robert Shufeldt exclaimed that America must "export these products or deport the people who are creating them." ${ }^{, 39}$ In this sense, unchecked economic growth presented a doubleedged sword, a great contradiction as both nations relied on immigration of non-Anglos and foreign consumption for economic success. This contradiction and influx of individuals began to challenge who was and who was not an American or a Canadian. In both cases it drove the nations towards their own imperial projects. The United States was forced to look outward, to export the massive amounts of goods aimed generally at the Chinese market, the great economic prize of the $19^{\text {th }}$ century. In Canada, the filling of its interior began to create such a surplus of agricultural products that the nation practically transformed into the pantry of the British Empire, exporting their agriculture to the United Kingdom and beyond. ${ }^{40}$ As the $19^{\text {th }}$ century drew to a close, it became increasingly clear that this expansion of federal and economic power would

steamships almost completely replaced sailing ships." Additionally, he notes the quickening pace of voyages and the significant reduction of death on these voyages from disease. I make the point not to claim the barrier of transit completely disappeared. For some of the poorest individuals things like fares for the voyage may have still presented some hurdle to gain entrance into the America's, however small that hurdle was.

${ }^{39}$ Jacobson, Barbarian Virtues, 18. Schufeldt was an advocate of opening Korea to American trade in the 1870s.

${ }^{40}$ Belich, Replenishing the Earth, 417. Canada's attachment to Britain via the commonwealth left it in a position to greater understand the tastes and desires of Britain's market according to Belich. He writes, "'Canadian farmers became attuned to the preferences of the British market and learned how to produce lean 'Wiltshire side'. The farmers of Ontario also managed to replicate the farming of Cheddar, a village in Somerset, and again they did so rather better than their US rivals... By the mid-1890s, sending cheddar to Britain, like coals to Newcastle, 'had become Canada's leading export'. Dairy-product exports in 1900 were twice the value of wheat exports. At its peak in 1903, this re-colonial dairy industry pumped over 100,000 tons of Canadian cheddar into Britain, comprising 80 per cent of Ontario's output and 95 per cent of Britain's cheddar imports." 
force nations to address the concept of citizenship. The expansion physically of the United States and economically of Canada forced both nations to contemplate their national make up.

In the States, the increasing dependence on foreign labor coupled with the growth of American legal jurisdiction. The "migration of the state" required a reworking of policy on who could hold citizenship within the United States. ${ }^{41}$ This phenomenon, largely an American one, occurred as the United States stretched its influence deep into the Pacific region, attempting to secure sea lanes to China. Needing territories to refuel and dominate those sea routes, the United States was faced with some degree of an extension of federal rule. Politicians struggled with the classification of individuals in these territories, thought unable to even self-govern. Facing potentially millions of Pacific Islanders and Asians quickly becoming part of the American project, politicians extended the growing use of exclusionary policies based on race beyond continental America. The prime example in the United States was the annexation of Hawai'i. Americans greatly feared the annexation of the islands particularly due to the thorny issue of non-native whites gaining the vote and other aspects of citizenship. However, when the white planters overthrew the native Hawaiian government and formed a white only society of franchise and citizenship, the problem of how to incorporate Hawai'i appeared to be self-solved. With the native Hawaiians disenfranchised by a white Hawaiian government, the annexation of Hawai'i could be accomplished by the United States without the American government having to make difficult racial decisions. This process allowed the United States to easily swallow the annexation of the island chains. ${ }^{42}$ As the United States took careful steps into the realm of imperialism,

${ }^{41}$ Jacobson, Barbarian Virtues, 222.

42 Ibid., 236. Jacobson writes that Americans feared annexing Hawai'i and dealing with the issue of nonnative whites gaining the vote and other aspects of citizenship. When the planters overthrew the native Hawaiian government and formed a white only society of franchise and citizenship, Hawai'i appeared to be a problem that self-solved. 
immigration policy, particularly immigration restriction policy, remained the other tool to define who is "American." This included who can become "American," and who by no means has that ability. ${ }^{43}$

The Canadian imperial moment, the settlement of the west, witnessed a similar "migration of the state." The movement westward into the prairies brought conflict and selfreflection to Ottawa. The issue of native peoples, and particularly the Métis, forced Canadian law makers to rethink the meaning of their confederation. In Canada's case this was a confederation built on a pluralistic society, at the very least between Anglo- and French-Canadians. The conflict over this idea forced the nation to look deeply at who was not part of the great Canadian experiment, ultimately deciding on excluding Asians, southern and eastern Europeans, and at times alienating their own French-Canadian populations. As Ottawa carved provinces out of the interior territories, it became increasingly evident that the pluralistic society was meant only for those of direct, largely British, but also European heritage. ${ }^{44}$ Even with the lip service paid to this noble idea of pluralism by ministers in the halls of parliament, Canada was increasingly following the pattern of other Anglo-nations erecting the "great white walls" in the 1880s. The walls of immigration policy erected in the late $19^{\text {th }}$ century kept the Dominions not just white but more importantly, British. ${ }^{45}$ As Canada colonized its great prairies, it became increasingly vital to regulate who would become Canadian and who was excluded from that right for the good of national economics. By protecting its British heritage, Canadian goods could easily be marketed into British markets around the globe, keeping open a vital corridor of trade.

\footnotetext{
${ }^{43}$ Erika Lee and Judy Yung, Angel Island: Immigrant Gateway to America (New York: Oxford University Press, 2010) 6; Erika Lee, At America's Gates: Chinese Immigration During the Exclusion Era, 1882-1943 (Chapel Hill: University of North Carolina Press, 2003), 22. Lee writes, "Through the admission and exclusion of foreigners, the United States both asserted its sovereignty and reinforced its identity as a nation."

44 The Red River Rebellion and the forcible exclusion of First Nations peoples and the Metis show Canadian will to dominate the interior.

${ }^{45}$ Belich, Replenishing the Earth, 467.
} 
The codification of race into national law intensified throughout this period of increasing federalization. ${ }^{46}$ The nativist feelings of social exclusion on the continent did not remain in the realm of social construct but rather crossed over to federal policy. The birth of immigration policy driven specifically by race appears first with the Chinese Exclusion Act in the United States in 1882 and gathered steam throughout the century with various other laws to bar an individual's entry based solely on race. The exclusion of the Chinese in the United States grew out of a nativist push in California. Blatant racism and fears of being overrun by Chinese labor drove Californians to direct the federal government to act in an exclusionary manner. ${ }^{47}$ The exact same push was felt in Ottawa. Feeling the pressure from British Columbia over the number of Chinese men living in the province, parliament took action in 1885. The Macdonald government passed The Chinese Immigration Act, a head tax on any incoming Chinese migrant. Though not banning immigration completely, the tax was heavy at $\$ 50$ per person - a large sum for a common laborer. Even that was raised in subsequent years to $\$ 100$ and then $\$ 500$ by $1903 .{ }^{48}$ The passing of these laws in quick succession effectively sealed off North America to Chinese labor, highlighting the similarity not just in economic development but also identity and race development in both the United States and Canada.

Immigration reform based on racial exclusion had a direct linkage to foreign policy. The transformation of the concept and definition of "citizen" or "legal migrant" from a solid fact to a fluid state depends as much on foreign policy as it does on domestic policy. One instance where foreign policy shines through is with the example of individuals from India and their surrounding

\footnotetext{
46 This federalization is consistent with the rise of the nation-state across the Western dominated world. It should not be seen as an exclusively American occurrence but rather the United States taking part of a global phenomenon.

${ }^{47}$ Lee, At America's Gates, 21. Although Lee suggests various other reasons for exclusionary policies to be crafted such as class, gender relations, immoral behavior, "medical nativism," and sexual orientation, she concludes that race and racism "was thus not the only factor shaping immigration law, but it was the most important one."

${ }^{48}$ Knowles, Strangers at our Gates 72-73.
} 
regions. The migration of people from the Indian Sub-continent in the early $20^{\text {th }}$ century

challenged both nations in this regard. Canada's "Continuous Journey Regulation" adopted in 1908, was put into play to keep undesirables out of the country by restricting entrance only to those who booked passage straight thru from their home nation. Attempting to regulate "good British subjects" into the country, this law particularly aimed at those from India without resorting to the "distasteful and increasingly unacceptable practice of designating "undesirable immigrants' by race or nationality." ${ }^{49}$ The arrival of 376 East Indian immigrants in 1914 aboard the Komagata Maru tested the resolve of the Canadian officials, and the Canadians courts. Despite being chartered by a wealthy Sikh, Gurdit Singh, the Supreme Court of British Columbia denied their entry after two months in harbor. Crowds cheered as the HMCS Rainbow "escorted the steamer to sea." ${ }^{50}$ To smooth over any ill will between Canada and Great Britain, William Mackenzie was dispatched to London to make the case against Indian migration to Canada based on the grounds of good foreign policy, and for the health of the empire. ${ }^{51}$ The refusal to accept British subjects from India represents the growth of Canadian foreign policy as independent of imperial demands. Increasingly, along with the other Dominions, there was a feeling of being

${ }^{49}$ Ibid., 121.

${ }^{50}$ Knowles, Strangers at Our Gates, 121 This was largely aimed at the Pacific to limit, if not halt completely, migration from India and Japan. The Komagata Maru incident is not only one of Canada's most notable immigration events but also represents a full closure of the "Great White Wall" and Canada's quest for the "right type" of British subject. In recent years Canadian Prime Ministers have apologized to the Sikh community in Canada. PM Justin Trudeau on May 18, 2016 orated, "Canada does not bear alone the responsibility for every tragic mistake that occurred with the Komagata Maru and its passengers, but Canada's government was without question responsible for the laws that prevented these passengers from immigrating peacefully and securely, for that, and for every regrettable consequence that followed, we, are, sorry." Trudeau's apology, given on the floor of the House of Commons in Ottawa, came eight years after previous Prime Minister Stephen Harper made a similar apology in Surrey, British Columbia in 2008. "Trudeau Gives Komagata Maru Apology in House of Commons," CBC News, May 18, 2016, accessed December 1, 2016. http://www.cbc.ca/news/politics/komagata-maru-live-apology1.2587827; "Harper Apologizes in B.C. for 1914 Komagata Maru Incident," CBC News, August 3, 2008, accessed December 1, 2016. http://www.cbc.ca/news/canada/british-columbia/harper-apologizes-in-b-c-for-1914-komagatamaru-incident-1.47120.

${ }^{51}$ W.L. Mackenzie King, Deputy Minister of Labour, "Mackenzie King's Report on Immigration to Canada from the Orient \& immigration from India," Sessional Paper No. 36a-1908, 400.225 r, Bodleian Library, Oxford University, pg. 7. 
international equals with Great Britain, partners in empire rather than junior members of a league commissioned by London.

Eventually life became complicated for Indian migrants living in the United States as well. The issue of Indian migrants in the United States became muddied by imperial power, but with different respects to foreign policy creating a difference in immigration policy. The United States did not aim to create a "better Briton" in the U.S., instead good relations with Britain. Due to that, Indian migrants landing in western ports like San Francisco in the early decades of the $20^{\text {th }}$ century found a relatively warm welcome thanks to the cloak of British Imperial rule.

However, established Indian communities found themselves denaturalized when Indian Nationalist movements upset the delicate balance between India and Britain. To appease British wishes, the United States government dropped its fair treatment of Indian migrants, declaring them "not white" and stripping them of all rights. The story of one Vasihno Das Bagai illustrates the hardship of this abrupt change in policy. Das Bagai built a successful business, became a naturalized American citizen and was secure in his belief of holding American citizenship. He renounced his British citizenship to show his support of rising Indian nationalism. However, when the United States revoked his naturalization, life became so desperate that Das Bagai eventually committed suicide. ${ }^{52}$ While only one story, it is an illustration of how foreign policy trickled down to effect those on the ground in the United States and elsewhere.

Despite decades of largely open borders, the slow march of increasingly racialized immigration law intensified in the early parts of the $20^{\text {th }}$ century. Differences, as seen in the above examples, between alien migrants, desired immigrant settlers, and continental North Americans emerge. The movement of Canadians, Americans, and even Mexicans throughout the

\footnotetext{
${ }^{52}$ Lee and Yung, Angel Island, 145-6.
} 
continent occurred as part of a developing "labor market that increasingly kept immigrants at bay and relied on a redistribution of its own human resources." ${ }^{53}$ The wake of the First World War and the immediate post-war recession only intensified this inward-looking system. A series of new laws began to tighten the screws on immigration in North America, aimed even at European restriction, starting in 1919. Labor unrest in Winnipeg in 1919 opened the door for the new Immigration Act of 1919 in Canada. Attempting to seal off the country from socialist input, despite the strike being led by British born individuals, Ottawa restricted migrants who may have been part of socialist organizations but also importantly gave the opportunity to add further immigrant tests, including for the first time a literacy test. ${ }^{54}$ South of the border the rapid change in demographics over a half century created a heavy nativist push. By early 1921 the first of the so-called "Quota Acts" was introduced as the Immigration Act of 1921 in the United States. The Act became the first step by Congress to limit migration based on a percent of nationality, 3 percent, tied to the 1910 census. Even as the economies improved, immigration restriction continued to remain strict.

Immigration law continued to tighten across the continent in the early half of the 1920s, completing the "great white wall" policy. Following a series of Privy Council rulings, the Canadian government not only outright barred Asian immigration, but also crafted a very narrow scope of what type of Europeans were sought after in the nation. Outside of agriculturists, farm labourers, or domestic servants, immigration into Canada was largely restricted to the white

\footnotetext{
53 Angelika Sauer, "The Construction of Borders: Building North American Nations, Building a Continental Perimeter, 1890s-1920s," in Migrants and Migrations in Modern North America by Dirk Hoerder and Nora Faires, (Durham, NC: Duke University Press, 2011), 223.

${ }^{54}$ For more on the Winnipeg Strike see, Reinhold Kramer and Tom Mitchell, When the State Trembled: How A.J. Andrews and the Citizens' Committee Broke the Winnipeg General Strike (Toronto: University of Toronto Press, 2010); Knowles, Strangers at Our Gates 134; Library and Archives Canada, Statutes of Canada, An Act to Amend the Immigration Act, 1919. Ottawa: SC 9-10, George V, Chapter 25. www.pier21.ca/reseasrch/immigrationhistory/immigration-act-amendment-1919
} 
British Dominions and the United States. ${ }^{55}$ Few exceptions were made as Canada entered its most restrictive era of immigration. Likewise, the introduction of the Johnson-Reed Act in 1924 in the United States further capped the growth of federal racial policy. Historian Mae Ngai called the Johnson-Reed Act "part of an emergent race policy that was broader, more comprehensive, and national in scope. In addition to immigration law, that policy involved the legal justification for de facto segregation in the North..." ${ }^{n 6}$ Although the Johnson-Reed Act was referred to as one of the "Quota Acts," this is a Euro-centric view. For many non-European populations, especially those originating from Asia and the Pacific, the Act barred all immigration. The barring and quotas implemented further drove public perception on the racial quality of those excluded.

For the Maltese, their story in North America coincides with the era of exclusion. Certainly there were trickles of Maltese who made the Atlantic crossing prior to the $20^{\text {th }}$ century, and many of them were drawn by the expansion of industry in both Canada and the United States. Some Maltese created a small community in New Orleans in the late 1700s, but little is known about this community. The most famous Maltese-American of early note was John Pass, a Maltese ironworker who helped recast the now famous Liberty Bell. ${ }^{57}$ But these individuals

${ }^{55}$ P.C. 183, January 31, 1923, section 5, 6. in "The Immigration Act and Regulations," Department of Immigration and Colonization,(1926), 47. "The Immigration Officer in Charge may notwithstanding the provisions of P.C. 23 of the $7^{\text {th }}$ January, 1914, permit to land in Canada any immigrant who otherwise complies with the provisions of the Immigration Act, if it is shown to his satisfaction that such immigrant is, - .. (5) Any United States citizen entering Canada from the United States who shall satisfy the Immigration Officer in Charge at the port of entry that he has sufficient means to maintain himself until employment is secured. (6) Any British subject entering Canada directly or indirectly from Great Britain or Ireland, Newfoundland, the United States of America, New Zealand, Australia or the Union of South Africa, who shall satisfy the Immigration Officer in Charge at the port of entry that he has sufficient means to maintain himself until employment is secured: Provided, that the only persons admissible under the authority of this clause are British subjects by reason of birth or naturalization in Great Britain or Ireland, Newfoundland, New Zealand, Australia, or the Union of South Africa... And Provided further that the provisions of this Order in Council shall not apply to immigrants of any Asiatic race." A further Order in Council restricted not just those who could enter but forced non-British individuals to possess a passport and Canadian visa in order to enter. P.C. 185, January 31, 1923, sections 1, 2. in "The Immigration Act and Regulations," Department of Immigration and Colonization, (1926), 47.

${ }^{56}$ Mae Ngai, Impossible Subjects: Illegal Aliens and the Making of Modern America (Princeton, NJ: Princeton University Press, 2004), 8.

${ }^{57}$ Sarah Carabott, "Maltese link to US liberty" Times of Malta. July 4, 2013. 
largely fell into historical afterthoughts, simply flashes in the pan of North American history.

The first to make a lasting impression of the earlier migrants was Louis Shickluna. Migrating to the United States for work in the early 1800s, he soon was given an offer to run a dockyard in St. Catherines, Upper Canada (now Ontario). He became immensely successful, earning the respect of those in the community and passing along his business before dying in $1880 .{ }^{58}$ Shickluna represents the type of Maltese that would come in the later years. Settling in the borderlands of Canada and the United States, he was able to make the best use of his British status and his enterprising skill, servicing the entire Niagara region from Buffalo to Toronto. But all of these early Maltese migrated far before immigration policy, particularly immigration policy built on ethnicity, took great effect. As immigration law came into play, a very important distinction was made. At the very core, Canada sought to build a "better Britain" by refusing even British subjects that were not deemed the right "type of Briton." In the United States, the policy was largely built to refuse migrants based on skin tone and secondarily on religion. For most migrants looking at North America, they fell into both camps, either not British and not white, or British and white. By being quasi self-governing British subjects and nominally white, the Maltese fell into the narrow gulf between what seemed to be indivisible immigration policy in the United States and Canada.

The Maltese migration experience, in large enough numbers to be seriously considered a "movement," began in the 1910s with the attempted passage conducted by Dr. Mattei. When the Maltese began to migrate to Canada, their Britishness was called into question. It was not simply foreign, or imperial, policy that spoiled the Canadians on the Maltese. As mentioned in the

\footnotetext{
${ }^{58}$ St. Catharines Museum, "Remembering the master shipbuilder Louis Shickluna," St. Catharines Standard, December 7, 2014. http://www.stcatharinesstandard.ca/2014/12/07/remembering-the-master-shipbuilderlouis-shickluna.
} 
previous chapter, the hectic manner in which they migrated ultimately ruined their "Britishness" in the eyes of Canadians. The scheme was supposed to draw migrants to British Columbia in order to settle land in Canada's west, aligned with the grand scheme of Canadian immigration policy. The mishandling of the news in Malta meant hundreds of men paid their own passage, drawn to Canada to do honest work and make a living. Many knew little about what to expect on the other side of the Atlantic. Many of the Maltese refused to be shuttled as part of labor gangs under the employ of the major Canadian corporations like the CPR, clearing woodlands for rail expansion or settlement. Several told stories of how they simply left the Canadian frontier, some after experiencing the icy grips of northern Quebec, almost all hoping to find work in emerging cities of the Dominion. ${ }^{59}$ The Maltese, and other migrants, refusal to work in labor pools at the frontier and rather opting to settle in the cities created an increasingly difficult political situation for the Canadian government. ${ }^{60}$ Coming independent of a contract, which was cancelled with Dr. Mattei in 1913, no Canadian corporation nor the Canadian government had any control over their movements. ${ }^{61}$ As the post-war years rolled in, Ottawa decided that a complete rejection of the Maltese based on their lack of full British status would save a long term hassle. But by basing the rejection of Maltese on an arbitrary reading of "Britishness" left the door open for debate on their inclusion deep in the 1920s.

\footnotetext{
${ }^{59} \mathrm{Mr}$. Sam Coleiro and Mrs. Carmelo Coleiro, interview by Richard Cumbo, Toronto, ON, March 13, 1978, Multicultural Historical Society of Ontario Archives, MAL-2854-COL, Toronto, ON.

60 "The Maltese migrants who have been going to Canada during the last ten years have gradually dribbled into the towns or crossed into the United States. But it should be kept well in mind that this propensity is by no means peculiar to our countrymen alone, for it is an open secret that the Dominion Authorities are at a loss how to arrest the movement from the land into the towns, and the exodus from Canada into the United States, especially from the Province of Quebec." Henry Casolani, Report on Emigration and Unemployment, 1926. Malta: Government Emigration Office, 9 September 1926, Document attached to Consul Sidney E. O'Donoghue to Malta to the Department of State, 12 October 1926, 849B.56/18, RG 59, Records of the Department of State, NARA II, College Park, MD, 10.

61 “Memorandum," Dominions Office, 17 Victoria Street, London, August 1913, RG 25 B-1-b Vol. 148 F. C8/1, Department of External Affairs fonds, Colonial Office (United Kingdom) - Emigration of Maltese to Canada, Library and Archives Canada, Ottawa, ON.
} 
The experience in the United States was vastly different for the Maltese. Although the Maltese had established small communities across the United States before World War I, the immense population of the nation meant they were at best a blip on the radar. However, those communities set the stage for a larger migration in the post-war era. Drawn to industrial centers like Detroit or to the ever-popular New York City, the Maltese began to register for many Americans. In the post-war years, the Maltese who came to the United States did so almost exclusively through their own power, with little to no government assistance. This was due to the make-up of this migratory group as skilled labor headed to Detroit with specific work in mind. A government of Malta report in 1920 illustrated why so many skilled Maltese migrated to the Motor City, stating Detroit operated “2,800 odd manufacturing establishments...providing work for 229,000 workers" and claims men "may be drawn [by] the illimitable capacity enjoyed by this rising city of the West." ${ }^{62}$ With a huge post-war demand for skilled labor, those men enjoyed not just preference in hiring but fair wages - well above the wages they could command in Malta. ${ }^{63}$ Even more than their skilled labor sets the Maltese who came did so for the most part not as transient labor but rather as migrants settling in to the fabric of the city. This type of migrant made wonderful first impressions of the Maltese to Americans. ${ }^{64}$ The response was so positive that they were able to use their "Britishness" as an advantage when attempting to navigate the ever fluid racial categorization of people, something denied to those Maltese in Canada.

62 Joseph Howard, Report on Emigration, 1918-1920. Malta: Department of Emigration, 21 May 1920, Document attached to Consul Carl R. Loop to Malta to the Department of State, 24 May 1920, 849B.5611/2, RG 59, Records of the Department of State, NARA II, College Park, MD, p. 6, sec. 6-7.

${ }^{63}$ Brian Barttelot, "Rear Admiral Barttelot to SECRETARY OF STATE, Malta," 31 March 1920. To Secretary of State, Piece No. 94, Malta National Archives, Rabat, Malta.

${ }^{64}$ Bernice Stewart, "Detroit's Maltese Colony is Largest in America," Detroit Free Press, December 12, 1920. Stewart's article in the Free Press proclaims that the Maltese "are hardly distinguishable from Americans...on the whole they look rather like Americans. Their children especially are like American children in looks and manners." 
Therefore, the Maltese migration experience in North America complicates the theory of a unified "great white wall". Their migration exposed the differences that existed under the surface between the United States and Canada and throws into doubt the solid nature of continental exclusion. For in Canada, the rejection of the Maltese comes thanks not to their whiteness, or lack-thereof, but Canadian officials routinely noted their lack of "Britishness." One could argue that the growth of the Canadian imperial project focused on the settlement of the west, and without agricultural skills it made perfect sense for Canada to reject the Maltese who only sought to settle in urban areas. However, this ignores the rapid pace of industrialization in the Toronto and Montreal region, growth that could have easily accommodated any Maltese migration. The legacy of searching for western settlers gave Canada a fall back in rejecting the Maltese and British overtures for a greater acceptance into the Dominion. Despite Malta's quasiself-governance, the types of Britishness found in the Dominions at times differed greatly from the Britishness forming in the colonies. ${ }^{65}$ While London may have wished to see a more unified Empire in terms of migration and flowing of labor as evidenced by the British Nationality Act of 1914, the Dominions sought to create a "Better Britain" founded on exclusively white Britishers. The mixed status of the Maltese then allowed just enough uncertainty to shut the door to their inclusion in Canada.

Exclusionary immigration policy in the United States was also challenged in a different manner. As Southern Europeans and devout Catholics, no doubt the Maltese normally would have been barred full entry to the United States based on their race and their religion. But the

${ }^{65}$ Kent Fedorowich and Andrew S. Thompson, eds. Empire, Migration and Identity in the British World, (New York: Palgrace Macmillan, 2013), 4. Fedorowich and Thompson write that "Britishness is not simply about 'whiteness' or its global reach. There were, as several scholars are at pains to remind us, 'subaltern' forms of Britishness which developed among indigenous peoples - a multiplicity of responses that originated at the local and regional levels." Belich argues the opposite however stating that "The Dominions cherished their racialist immigration barriers because they believed it kept them British, not just white." 466. 
manner in which the Maltese settled in Detroit and the strength of their British status opened a certain amount of leeway. American Consulates in Valletta typically sent back to Washington glowing reports of the Maltese people and the type of migrant wishing to enter the United States. ${ }^{66}$ Consul Sidney E. O’Donoghue wrote that the process of Emigration was one controlled by the Maltese government, and that "only one Maltese applicant for entrance to the United States has been rejected and this is for something over which neither the Emigration Office nor this Consulate had any control." ${ }^{\prime 67}$ O'Donoghue would go on to call them "an assimiliable race." Just three years earlier, his predecessor Mason Mitchell, wrote that the Maltese "are considered one of the best class emigrating" to the United States. ${ }^{68}$ The Maltese had one more fall back, their British status. Thanks to their imperial connection, Maltese immigrants proceeded to the United States under the British quota. This essentially left the quota number not in the hands of Washington, but rather in London where the British government doled out what it saw fit for the Maltese to receive. Starting with just an allotment of 10 immigrants per year on July 18, 1924 the Maltese pressured both the United States and Great Britain to increase the quota with great success. By fiscal year 1929-1930, the quota number rose to 540, a dramatic increase. ${ }^{69}$ A good

\footnotetext{
${ }^{66}$ The missives sent back to Washington from almost all of the Consuls in the 1920s laud the Maltese immigrant and push for a higher quota to be allowed. These records can be found at the United States National Archives II in College Park, MD.

${ }^{67}$ Sidney E. O'Donoghue, "Necessity of increased emigration from Malta," Malta to the Department of State, 7 September 1926, 849B.56/17, RG 59, Records of the Department of State, NARA II, College Park, MD, 2.

${ }^{68}$ Ibid.; "The Maltese Emigrants: Tribute From the American Consul in Malta," Daily Malta Chronicle attached to: Mason Mitchell, "Tourist Traffic in Malta and Maltese Emigrants," Malta to the Department of State, 21 April 1923, 849B.56/13, RG 59, Records of the Department of State, NARA II, College Park, MD.

${ }^{69}$ Hugh Arrigo, “Annual Report of the Emigration Department, 1929-1930," Malta Government Printing Office, 20 September 1930, XX, attached to: Hugh S. Miller, "Emigration from Malta," Malta to the Department of State, 18 October 1930, 849B.56/25, RG 59, Records of the Department of State, NARA II, College Park, MD. A much later telegram to Washington in 1954 argues that the Maltese were frustrated under the McCarran restrictions of the era "after unlimited emigration under British quota." Further, Maltese individuals have archived emigration papers from the early 1930s that show the US government bringing them in under the "British" quota. Paddock, "Regarding Contel 77 May 19 repeated London 17," Malta to the Department of State, 21 April 1923, 747B.00/52654, RG 47, Records of the Department of State, NARA II, College Park, MD; "Joseph Cachia Immigration Papers," 2 April 1930, 1405-89-9, SR 5108, Archives of Ontario, Toronto, ON.
} 
first impression and political pressure was all needed to break a hole in the "Great White Wall" in America.

The historical similarities between the United States and Canada cannot be understated. Both nations develop along a nearly identical path from a metanarrative standpoint after 1867 . As their economies boomed and became entwined with one another so too did political and social policy. Staring out at the world in 1920 , it would have been very difficult to differentiate between Canadian and American policy. Rampant industrial capitalism and expanding imperial projects categorized the nations of North America as emerging industrial and political powers within the world. Each looked to control the identity of their country's citizenship by erecting similar immigration policy. Yet, by digging into one small community, the Maltese, it becomes evident that differences in the way each nation crafted identity and race certainly existed. In Canada, foreign policy - largely imperial policy - became an entangled mess frustrating both the government officials and the Maltese migrant. Maltese rejection in Canada was based on a racial creation of a British identity coming from within the imperial structure. Within the Dominion, the Maltese standing in the empire resulted in a racial "othering" that excluded them. The very same imperial structure that rejected the Maltese in Canada however punches their ticket to the United States. The economic needs of the nation, the skill sets of the Maltese, and their position in the British Empire craft a completely different social construction and therefore a brighter future. More is at play than simply policy. The communities on the ground had a large role in the shaping of their perceived racial and social status in their new host country and therefore the success or failure of their fellow compatriot's future migration. And that is truly the unique argument of studying the Maltese. By looking at both the governmental policies and economics 
as well as the communities themselves we see how all of these factors influenced immigration on previously unexplored levels. 


\section{Chapter 4 - Maltese in Canada}

Questions must have raced through George Brincat's head as he stood with his family at the Detroit-Windsor border in June of 1925. The American family in front of them was allowed entrance into Canada, but the Brincats were denied, or more accurately stamped as "Rejected." The twenty-nine-year-old with his wife, a year younger, and their four-year-old son were all British subjects attempting to enter Canada, a British Dominion, with British passports to visit a friend in Toronto. It was not as if he was an undesirable seeking refuge. George Brincat had served in the British Navy during the Great War and was honorably discharged after the war, when he left his native Malta to find work in the booming western metropolis of Detroit. Arriving at the border in 1925, Brincat, a Ford Motor Company employee, stood frustrated and most likely confused by the rejection of his family's entrance to Canada, a Commonwealth nation. Further infuriating for the family, Canadian officials lumped them with Russians, Lithuanians, Hungarians, and Armenians, all denied entrance into Canada that day as well. Perhaps George had never heard of Privy Council 183 or 185, but the official notations citing these legal rulings above the stamped "Rejected" explained Canada's denial. ${ }^{1}$ While Maltese could enter the United States as British citizens classified as white, the Canadian law refused their entry by crafting a very narrow definition of "British subject."2 Although the Brincats were

\footnotetext{
${ }^{1}$ Library and Archives Canada, Ottawa, Ontario, Canada; 1908-1935 Border Entries; Department of Employment and Immigration fonds, R.G. 76-C; Roll: T-15347; Interview with Joseph Brincat by the author, Detroit, Michigan, March 16, 2014.

2 P.C. 183 Section 6 states "Any British subject entering Canada directly or indirectly from Great Britain or Ireland, Newfoundland, the United States of America, New Zealand, Australia or the Union of South Africa, who shall satisfy the Immigration Officer in Charge at the port of entry that he has sufficient means to maintain himself until employment is secured; PROVIDED, that the only persons admissible under the authority of this clause are British subjects by reason of birth or naturalization in Great Britain or Ireland, Newfoundland, New Zealand, Australia or the Union of South Africa."
} 
British subjects, they simply were not the right kind of British subjects to gain entrance into the Dominion.

The Brincat story is likely just one of what were many similar experiences of Maltese individuals attempting to navigate the British imperial world. While this particular family simply attempted to visit Canada on a short stay before returning to the United States, many others sought to make Canada their permanent home. The movement of this very small population of people, just over one thousand Maltese by 1928, illustrates how politics and identity seeped into the construction of imperial emigration policy. ${ }^{3}$ The story of the Maltese in Canada is both one of empire and one of race. This chapter attempts to show how the movement of a small population of migrants forced a greater discussion about British subject status within the empire. What was in question was the identity of the Maltese and their rights as British subjects. The movement of the Maltese within the supposed "free-market for [the movement of] labour" within the empire exposed tensions between Dominion and Metropole over the truth of that policy. ${ }^{4}$ Exploring the political debates on the Maltese ability to enter Canada as full British subjects, this chapter will start with the pre-World War I migrations of Maltese where the question of their "whiteness" became a heated topic and the lives of Maltese in Canada were quite difficult. It will then move to the post-war world where the combination of Maltese war

\footnotetext{
${ }^{3}$ F.C. Blair, "Memorandum to Mr. Cullen," Department of Immigration and Colonization, Ottawa, Canada. 21 March 1928. Canadian National Archives: Ottawa, Canada. RG 25 A-3-a Vol 1327 F. 1090/22 - 610747.

${ }^{4}$ Historian Stephen Constantine presented British emigration within the commonwealth in his 2003 work "British emigration to the empire-commonwealth since 1880." The work is an in-depth analysis of the growth in the concept of a British diaspora, tracking migrations of British people over the course of more than a century. While he focuses mostly on the concept of diaspora, diving into the questions of what makes a diaspora and exploring the true meaning of the word, he makes several pointed insights into the workings of the imperial migration network that open questions for the Maltese. This concept of who can be classified as British and make up the diaspora drives Constantine's work and raises the question of where a peoples who may be "in-between" lie. This concept of equality in the empire is incredibly significant as Constantine explains in discussing the movement of British peoples within the Commonwealth. Stephen Constantine, "British emigration to the empire-commonwealth since 1880: From overseas settlement to Diaspora?," The Journal of Imperial and Commonwealth History, Vol. 31, No. 2, (2003).
} 
efforts and the British Nationality Act reshaped the parameters of Maltese identity. As this reshaping took place, the Maltese community in Canada grew slowly, despite Canadian attempts to omit them based on a ranking of "Britishness." How the people on the ground built their community and reconciled their British, Maltese, and new Canadian identity in a nation where they were anything but welcome becomes the final focus of the chapter. Ultimately, this chapter argues that the benefits of empire for the Maltese in Canada was a contested issue. Politically, there was little benefit despite a massive push by British policy. But socially, the ability to wear the cloak of Britishness gave them advantages over other immigrant groups in integration and advancement. Ironically, a claim to Britishness may have been more helpful in the United States than it was in a British Dominion.

While both the United States and Australia took a significant number of Maltese, Canada did not. This raises several questions, but when one begins to drill down into the reasoning why there appears to be a simple answer. Since Confederation in Canada, the immigration policy of the nation had been a fairly consistent one. Growth of the Canadian population would be tightly managed and directed to the frontier. ${ }^{5}$ For a new Canadian government in 1867 , this represented a logical and needed policy as the West had to be incorporated into the new nation. British

\footnotetext{
5 Those migrants that populated the early settlement of the Canadian West were not generally "Britishers" but rather Scandinavians, Central and Eastern Europeans. So long as they took to the prairies and settled the expansive west, Canadian immigration officials sought to include these individuals in the Canadian immigration experience. When it came to populations intending to live and work in urban Canadian settings, it was there that immigration officials took a much tighter view of who was and who was not a proper "British" individual. For works on various ethnic communities in Canada including Mennonites, Ukrainians, and Irish see; John Beno Toews, Lost Fatherland: The Story of the Mennonite Emigration from Soviet Russia, 1921-1927 (Vancouver: BC Regent College Publishers, 2003); Harry Piniuta, Land of Pain, Land of Promise: First Person Accounts by Ukrainian Pioneers, 1891-1914 (Saskatoon: Western Producer Prairie Books, 1978); Lubomyr Y Luciuk, Searching for Place: Ukrainian Displaced Persons, Canada, and the Migration of Memory (Toronto: University of Toronto Press, 2000); Radomir Borislaw Bilash, The Colonial Development of East Central Alberta and its Effect on Ukrainian Immigrant Settlement to 1930 (Ottawa: National Library of Canada, 1983); Robert McLaughlin, Irish Canadian Conflict and the Struggle for Irish Independence, 1912-1925 (Toronto: University of Toronto Press, 2013); Mark McGowan, Waning of the Green: Catholics, the Irish, and Identity in Toronto, 1887-1922 (Montreal: McGill-Queen's University Pres, 2014).
} 
Columbia and the Hudson Bay Company, lingering out to the west, would be bridged by the influx of population to the prairies. ${ }^{6}$ As the American push westward continued, Canada felt pressured to achieve the national dream of stretching from ocean to ocean. The central Canadian provinces of Alberta, Saskatchewan, and Manitoba had vast untapped potential as grain baskets for both the nation and for export, so it was there that the desire to admit farm laborers and agricultural settlers was born.

What ultimately evolved in Canada was a set of restrictions that kept the nation shut to the same sorts of immigrants then being denied access to the United States. The amendments to the Immigration Act in 1919 effectively gave Canadian officials the ability to discriminate against racial groups they believed to be "unsuited to the climate and requirements of Canada," and it empowered the Cabinet "to prohibit any race, nationality, or class of immigrant by reason of "economic, industrial, or other condition temporarily existing in Canada."7 This moment in history represented a crucial crossroads in the story of global migration. The restrictive era, as it is known in the United States, applied to Canada as well. During this time the tale of the Maltese migration became perplexing. In contrast to the belief of a "free market for labour" within the British Empire, the Maltese found migration to Canada and Australia extremely limited. ${ }^{8}$

As with nearly all stories of immigration, economics played a crucial role in the early stages of migration. The attempted move of the Maltese to the Dominion in 1910 was not only a preferred location thanks to the British connection, but also necessary given the dire economic warnings coming from the United States. The banking crisis and subsequent Panic of 1907 in the

\footnotetext{
${ }^{6}$ Valerie Knowles, Strangers at Our Gates: Canadian Immigration and Immigration Policy, 1540-1997 (Toronto: Dundurn Press, 1997), 8; Ninette Kelley and Michael Trebilcock, The Making of the Mosaic: A History of Canadian Immigration Policy (Toronto: University of Toronto Press, 1998), 62.

${ }^{7}$ Kelley and Trebilcock, The Making of the Mosaic, 184.

${ }^{8}$ Stephen Constantine, "British emigration to the empire-commonwealth since 1880: From overseas settlement to Diaspora?," The Journal of Imperial and Commonwealth History, Vol. 31, No. 2, (2003).
} 
United States kicked off a deep industrial recession. The Panic was not confined to just the United States; during 1907 markets collapsed around the world, toppling German, Dutch, Italian, and Egyptian markets as well. ${ }^{9}$ This crisis stunted the need for immigrant labor as factories idled and U.S. unemployment shot up from $2.8 \%$ to $8 \%$ in a matter of months. Responding to this unemployment, immigration fell to a low of 750,000 in 1909 compared to 1.2 million in 1907. The slow recovery was referenced in a 1910 letter from then Governor of Malta, Leslie Rundle, who described, "no prospect of employment for Maltese in the United States owing to the number of working-men who were already out of employment." 10

The warning against migration to the United States did not come with an open invitation of migration to Canada. Although Canada experienced an economic boom during the early $20^{\text {th }}$ century that witnessed its annual growth rate briefly eclipse that of the United States, it was not wholly impervious to global economic conditions. From 1909-1913, Canadian business underwent several changes and experienced major mergers as well as changes in scope and funding. Slowly Canadian industry turned away from Britain and moved towards better ties with their American counterparts like General Motors. ${ }^{11}$ As Canada grew, unrest bubbled under the surface. Connected to Eastern ports by the Canadian Pacific Railroad, Winnipeg boomed as a capital of wheat and prairie industry. It also became Canada's most unionized city by 1910 , aided by pro-union immigrant labor from England and union activists from the United States, particularly Detroit. ${ }^{12}$ Canadian officials tied the growth in union sentiment tied directly to

\footnotetext{
${ }^{9}$ Robert Bruner and Sean Carr, The Panic of 1907: Lessons Learned from the Market's Perfect Storm (Hoboken, NJ: John Wiley \& Sons, 2007), 142.

${ }^{10}$ Leslie Rundle, "Letter from the Governor," The Palace - Valletta, 9 June 1910, Department of External Affairs fonds, Colonial Office (United Kingdom) - Emigration of Maltese to Canada, RG 25 B-1-b V. 146, F. C5/82, Library and Archives Canada, Ottawa, Canada.

${ }^{11}$ Don Nerbas, Dominion of Capital: The Politics of Big Business and the Crisis of the Canadian Bourgeoisie, 1914-1947 (Toronto: University of Toronto Press, 2013), 9; 18.

${ }^{12}$ David Jay Bercuson, Confrontation at Winnipeg: Labour, Industrial Relations, and the General Strike (Montreal: McGill-Queen's University Press, 1990), 4; 11.
} 
immigrants. As the nation grew, Winnipeg experienced several strikes during the decade prior to the First World War. As disruptive as those strikes were, they were largely disguised by the positive national growth. However, depression hit Canada in 1913. It ended the rapid economic expansion and brought forth a grim picture across the nation. ${ }^{13}$ Officials recognized that the quality of migrant admitted into Canada had to be watched closely or risk further industrial revolt, this time without the protection of a humming economy.

Looking toward North America from Malta, the picture appeared bleak. With the United States suffering economically, soon followed by Canada, few long-term options appeared for Maltese migrants. Nevertheless, in Malta, Governor Rundle kept the long-term success of emigrants at the front of his considerations. He remained mindful of the economic impact on Malta if those migrants should fail noting, "It must be born in mind that Maltese who go abroad in search of employment and fail to obtain are...repatriated at the expense of the Government of Malta and it is therefore necessary to approach the question of emigration with great caution."14 Although emigration was an important question in Malta due to weakness in the local economy, the effect of having to pay for the return migrants made the work of finding suitable destinations more pressing. Governor Rundle's letter, however bleak, was the first in a chain of correspondences between Ottawa, London, and Valletta that all attempted to secure passage to and employment in Canada while simultaneously classifying the Maltese as favorable British subjects.

Canada initially denied the Maltese entry based on the type of migrant sought by the government and the type of Maltese laborer looking to go abroad. Canadian immigration policy

13 Ibid., 21.

${ }^{14}$ Leslie Rundle, "Letter from the Governor," The Palace - Valletta, 9 June 1910, Department of External Affairs fonds, Colonial Office (United Kingdom) - Emigration of Maltese to Canada, RG 25 B-1-b V. 146, F. C5/82, Library and Archives Canada, Ottawa, Canada. 
was fairly clear cut. The need in the nation was to fill the prairies with productive, and if possible, white settlers. The concept of "white" itself was fluid, as those who became productive settlers in the west easily transformed into the typical "white" European settlers Canada so desperately required. But a Maltese government official, Sir E.M. Merewether, noted that the farmers Canada sought to admit would "probably be the last to leave the Island, and as long as they can keep body and soul together in Malta, they will not go elsewhere." ${ }^{15}$ Rather, the men ready to leave Malta in 1910 - and the men that Malta desperately needed to emigrate - were unskilled laborers who could not speak English. Merewether mentioned that they were "vigorous men inured to hardship and fatigue, and well able to do rough jobs," but they did not possess the overall knowledge, or financial capital, necessary to become independent farmers. ${ }^{16}$

Nevertheless, the British government continued to push the issue of Maltese migration to Canada, ultimately revealing that the refusal to admit Maltese into the nation revolved around more than just a skill set. Racial discrimination against the Maltese in Ottawa's political circles, despite their British association, certainly existed. This racist view of the Maltese was part and parcel of the ever expanding "Great White Wall" erected across North America. Of course, the status of British subjects presented potential problems for the Canadians. Prior to 1910, natives of Malta could easily be written off by Canadian officials without much backlash due to their lack of farming experience. The only type of Maltese individual that experienced any success in emigrating to Canada were the white, Malta-born English, or the "Britisher Maltese." That type of Malta-born Englishmen, unsurprisingly, had the advantage in moving to Canada as their race and lineage were clearly Anglo. Native-born Maltese continued to be denied entrance by

${ }^{15}$ H.M. Merewether, "Letter from Malta," The Palace - Valletta, 10 October 1910, Department of External Affairs fonds, Colonial Office (United Kingdom) - Emigration of Maltese to Canada, RG 25 B-1-b V. 146, F. C5/82, Library and Archives Canada, Ottawa, Canada.

${ }^{16}$ Ibid. 
Canadian officials who, among other issues, blamed the climate, pointing to Malta's geographical position in Southern Europe compared to Canada's northerly position. According to the Lord Strathcona, Canadian High Commissioner to the United Kingdom from the Department of the Interior, the Maltese should not "encourage any considerable movement of these people to Canada until a few of them have 'made good." "17 Unfortunately for the Maltese, the type of migrant available for the journey was the exact type barred from entrance into Canada. With that, few if any could enter and therefore few if any would have the opportunity to 'make good' and pry open the doors of emigration.

The favoritism afforded the white, Malta-born English, illustrates the very thin line between the right and wrong type of British subject. The individuals who appeared as "Britishers in the Island of Malta" and communicated in English were welcomed, while other Maltese faced restriction. ${ }^{18}$ This differentiation in British subjects was directly attacked by the passage of the British Nationality Act, a law enacted after a 1911 Imperial Conference where the concept of identity across the Empire was discussed. ${ }^{19}$ The Act supposedly leveled the imperial playing field. Historian Stephen Constantine summed it up thusly;

The British Nationality Act of 1914, in an apparent gesture of equality, defined British citizens to include 'any person born within His Majesty's dominions and allegiances'. This seemed to imply for all such people, whatever their geographical or ethnic origins, a perfect free market for their labour and skills anywhere in the British Empire. In truth, global migration was taking place within a highly politicized structure in which some British Citizens were more equal than others. ${ }^{20}$

\footnotetext{
17 "Letter to Lord Strathcona," Department of the Interior, Government of Canada, Emigration Branch. 4 November 1910, Department of External Affairs fonds, Colonial Office (United Kingdom) - Emigration of Maltese to Canada, RG 25 B-1-b V. 146 F. C5/82, Library and Archives Canada, Ottawa, Canada, 1.

18 Ibid., 2. The letter states "the fact that the Maltese labourers referred to in the correspondence do not speak English, I am of the opinion that the Department would without hesitation decline to encourage their emigration to Canada."

19 "Naturalization Act, 1914," Canadian Museum of Immigration at Pier 21

${ }^{20}$ Stephen Constantine, "British emigration to the empire-commonwealth since 1880: From overseas settlement to Diaspora?," The Journal of Imperial and Commonwealth History, Vol. 31, No. 2, (2003), 21.
} 
As Constantine suggests, despite the apparent free market for labor, British citizens each held, in reality, different levels of citizenship. ${ }^{21}$ However, this reality did not apply equally across the empire and certainly external events influenced the politics of citizenship.

The outbreak of World War I dramatically changed Maltese fortunes within the Empire. Malta's geographic position in the Mediterranean elevated her status in terms of important colonies for the survival of the Empire. The islands served not just as a crucial link to India and Australia, but also as a staging ground for British troops and, most importantly of all, a fortified and safe hospital. This mixing of soldiers from all across the Empire in Malta exemplified the British Nationality Act and brought men from the Dominion face-to-face with the Maltese for the first time. Furthermore, as Maltese men joined the war effort their interactions and sacrifices with other imperial men cemented their belief that they deserved equality and full citizenship within the British system. If British equality formed around the principles of European heritage and western values, then the Maltese claimed equal footing with the Dominions in view of their clear European status, however much their whiteness was in dispute.

While a more complete and unified British identity gelled during the war in Malta, the Maltese community in Canada did its part as Maltese-Canadians during the Great War. Many of those earliest settlers of the Maltese-Canadian community found their way into the Canadian Armed Forces. Men like Paul Borg, who emigrated to Toronto in 1913, and the Camilleri

\footnotetext{
${ }^{21}$ In a 1926 Report on Emigration published by the Government of Malta, a nearly identical train of thought can be found, twelve years after the passing of the British Nationality Act. Henry Casolani, director of Emigration on Malta, locates the inequality specifically in the Maltese case stating, "In theory, as British Subjects of white European race, born in a self-governing State of the Empire, the native of Malta should enjoy free access without any bar or hindrance - proved he complies, in ever respect, with ordinary immigration requirements - to any other part of the British Empire. In practice he is, in most of the British Dominions, still regarded, for immigration purposes, as an alien." Henry Casolani, Report on Emigration and Unemployment, 1926. Malta: Department of Emigration, 9 September 1926. Document attached to Consul Sidney E. O'Donoghue to Malta to the Department of State, 12 October 1926, 849B.56/18, RG 59, Records of the Department of State, NARA II, College Park, MD, 1314.
} 
brothers all joined the Canadian Army at the outbreak of the war. ${ }^{22}$ Devotion to the cause seemed to be particularly poignant for a young Joseph Frendo who "on the outbreak of war...seems to have been in the U.S.A. and...crossed over into Canada at once to enlist. ${ }^{, 23}$ Frendo, a native of Hamrun, Malta, served with the $8^{\text {th }}$ Battalion of Manitoba, the "Winnipeg Rifles." Although he was listed as a Real Estate Agent in Malta, his appearance in the historical record on the North American prairies suggests that he may have been part of the failed Dr. Mattei experiment to take Maltese men to the continental west. Whatever the reason for his brief stay out West, the young soldier found himself back in Europe in the trenches of France in 1916. He spent a year stationed overseas before being discharged, suffering from pulmonary tuberculosis. ${ }^{24}$ Unfortunately for Frendo, he struggled with tuberculosis and the Canadian government simultaneously while attempting to gain early access to his pension in order to return to his native Malta. ${ }^{25}$ Canadian military officials refused to pay for his return to Malta from England because his birth place was listed as Malta. While doctors and imperial liaisons writing on behalf of Frendo bickered with Canadian officials in England, the Maltese community in Toronto even during the war - began to set down roots.

While the war raged on and Maltese did their part for the Empire, the relatively small community in Toronto began to solidify. In the summer of 1916, a Father Fortunatus of Valletta made the trip over the Atlantic to Toronto. While visiting, the Archbishop of the Toronto,

\footnotetext{
${ }^{22}$ Messrs. Joseph and Vincent Camilleri, interviewed by Richard Cumbo, March 10 \& 29, 1978. Toronto, Ontario, Canada. Multicultural History Society of Ontario Archives, MAL-2855-CAC, Box 128, Maltese C-S.

${ }^{23}$ W.H. Hinde, "Joseph Frendo," 3 November 1917, Department of External Affairs fonds, Colonial Office (United Kingdom) - Case of Joseph Frendo, a native of Malta, ex-private in the Manitoba Regiment, RG 25 B-1-b Vol. 156 C11/84, Library and Archives Canada, Ottawa, Canada, 2.

${ }^{24}$ F. Kincaid Etlinger, "Joseph Frendo," 16 October 1917, Department of External Affairs fonds, Colonial Office (United Kingdom) - Case of Joseph Frendo, a native of Malta, ex-private in the Manitoba Regiment, RG 25 B-1-b Vol. 156 C11/84, Library and Archives Canada, Ottawa, Canada.

${ }^{25}$ Henry Lambert, "Joseph Frendo," January 30, 1918, Department of External Affairs fonds, Colonial Office (United Kingdom) - Case of Joseph Frendo, a native of Malta, ex-private in the Manitoba Regiment, RG 25 B-1-b Vol. 156 C11/84, Library and Archives Canada.
} 
Reverend Neil McNeil, asked Fortunatus to survey the Maltese community so there would be a better understanding of their needs as they began to congregate in the dioceses. Fr. Fortunatus' survey showed a community that was not only miniscule - two hundred Maltese in total - but also heavily dominated by males in Canada for work. Of the two hundred Maltese, there were only fourteen families with twenty-seven children among them. However, the men who lived in Toronto apparently had no troubles in 1916 finding work as carpenters, bricklayers, electricians, and in other trades. ${ }^{26}$ Combined with thrifty living, the Maltese were able to turn these jobs into a financial cornerstone not just for the community in Toronto but also for their families back in Malta. One local Maltese community leader, a Mr. Azzopardi, noted by Fr. Fortunatus, managed to collect $\$ 300$ for a new church seminary in Toronto, much to the surprise of the Archdiocese. This local philanthropy was accomplished while most of the men sent a modest amount of money back to their families, between $\$ 25$ and $\$ 30$ a month. ${ }^{27}$

The few Maltese who congregated in Toronto clung tightly to the Catholic Church, not surprisingly considering their devotion to the Church in Malta and their ethnic isolation in Canada. The rare visit of Fr. Fortunatus, a Maltese priest, brought great acclaim in the community. He wrote to Archbishop McNeil that the members of the community greeted him "as if they met their fathers \& mothers. ${ }^{28}$ His visit not only culminated in a community census but also served a religious purpose. Fortunatus heard confessions from over three-fourths of the Maltese. That spiritual visit was important for the early formation of the community. As Fr. Fortunatus noted, the immigrant experience invited "fighting, drinking, bad conversations, and

26 "Rev. Fortunatus to Archbishop McNeil," 3 July 1916, Ethnic Catholics fonds, Series MN EC Ethnic Catholics, Item MN EC04.03, Archdiocese of Toronto Archives, Toronto, Canada, 1-2.

${ }^{27}$ Ibid., 2.

${ }^{28}$ Ibid. 
evil deeds, and, last but not least, separation from one's wife." ${ }^{29}$ The Maltese, in his humble opinion, had avoided all of those vices to that point, but the ability to do so in the future depended upon the installation of a Maltese language priest. Without the priest, something for which the community had earmarked $\$ 600$ a year, fears arose that the community would fall apart before reaching any sort of size that might last for generations. ${ }^{30}$ Thanks to their economic success in Toronto and the willingness to reinvest that success, the Maltese community in the post-war years reaped the benefits sowed during the war and grew tremendously, despite Canadian wishes to the contrary. It was in the war that the Maltese reshaped their British identity at home and legitimized their community in Canada, but it was the post-war world that brought about the greatest change to the Maltese globally.

Economic collapse, massive unemployment, and labor unrest filled the post-war years in Malta. The golden age of Maltese industry existed as an artificial economic bubble, one doomed to collapse with the cessation of hostilities in Europe. Underneath the WWI economic boom and job growth, costs of living rose and wages lagged. ${ }^{31}$ These difficulties led to Malta's first ever labor strike organized by the Imperial Government Workers Union (IGWU). First established by British workers in Malta at the onset of World War I, the IGWU grew in prominence among native workers at the dockyards. Responding to the rising cost of living, the Admiralty granted a

${ }^{29}$ Ibid., 3.

${ }^{30}$ Ibid., 4. Already without a priest, the letter from Fr. Fortunatous suggested that people were marrying outside the Catholic Church and outside the Maltese community.

${ }^{31}$ Wilbur Keplinger, "Cost of Living in Malta," Malta to the Department of State, 10 March 1917, 849B.5017, RG 59, Records of the Department of State, NARA II, College Park, MD, 2. Maltese bread rose 83\% (although "Superior quality" bread registered a 78\% rise); herring, flour, and potatoes 100\%; lard checked in at $167 \%$ higher while lump sugar was at $180 \%$ and granulated at 200\%.; Wilbur Keblinger, "Malta Postal War Tax," Malta to the Department of State, 19 December 1917, 849B.512, RG 59, Records of the Department of State, NARA II, College Park, MD, 1. The cost of war waged by the empire not only meant skyrocketing food prices but the implementation of further taxes to bolster the war chest. A "war tax" on letters, postcards, and parcels took effect in late 1917 on Malta for both local delivery and delivery to all parts of the United Kingdom and further commonwealth 
small pay increase of ten percent to help temporarily alleviate the harsh economic conditions.

This increase failed to satisfy demands. After two days of talks in May 1917, the strike

commenced. The Union approached the British government with demands for a fifty percent increase in wages compared to the ten percent offered. The Admiralty, fearing loss of use of the Royal Navy dockyard, acquiesced. ${ }^{32}$

Necessity of wartime production granted Maltese labor a short-lived victory, but at war's end there was a slowdown of naval activity. Tensions rose, the cost of living continued to climb, and many men lost positions at the dockyards. Dockyard workers further complained after finding that English-born dockworkers received a 100 percent raise following the 1917 strikes compared to the 50 percent given to native skilled labor. ${ }^{33}$ June of 1919 marked the climax of social unrest. Maltese workers took to the streets to protest the unfair wage raise, the continually rising cost of bread, and the "great increase in the cost of living" estimated at 160 percent above pre-war levels. ${ }^{34}$ The riots ended with four demonstrators shot dead by British authorities. ${ }^{35}$ This culmination of events led thousands of Maltese men, many of them recently unemployed, to look overseas for both employment and livelihood.

By 1919 the floodgates of emigration opened in Malta. Joseph Howard, chairman of the Department of Emigration in Malta wrote in his annual report that despite over 10,000 departures since the Armistice outbound migration had "barely touched the fringe of the numbers of which these islands should be relieved." 36 Less than a year later, Henry Casolani, the newly appointed

${ }^{32}$ Edith Dobie, Malta's Road to Independence (Norman: University of Oklahoma Press, 1967), 81-82.

${ }^{33}$ Carl R Loop, "Emigration of Maltese to the United States," Malta to the Department of State, 14 May 1920, 849B.5611/1, RG 59, Records of the Department of State, NARA II, College Park, MD, 1.

${ }^{34}$ Ibid.

35 "Struggle For Freedom," General Workers Union - Malta. http://www.gwu.org.mt/pages/Struggle_For_Freedom.aspx (accessed October 1, 2014).

${ }^{36}$ Joseph Howard, Further Report on Emigration, 1920. Malta: Department of Emigration, 28 October 1920. Document attached to Consul Carl R. Loop to Malta to the Department of State, 27 November 1920, 849B.56/5, RG 59, Records of the Department of State, NARA II, College Park, MD. 
Secretary of the Department of Emigration, put a number to Howard's "fringe," claiming the islands must be relieved of 50,000 potential migrants within a decade or face economic ruin. ${ }^{37}$ Despite the desperate need for population relief, Malta had few options within the empire. Much to the chagrin of British officials, the vast empty spaces of the Empire, particularly Canada, refused the Maltese. ${ }^{38}$ The Canadian refusal to accept Maltese men may have been colored by a growing fear in the west of socialism and its ties to labor activism. The "Red Scare" of the postwar world shook North America and brought about anti-immigration stances. With labor unrest in Winnipeg during 1919, led largely by British and other immigrant workers, Ottawa may have made its refusal of the Maltese based in part on growing labor union activism on the islands and a desire to keep that type of social activism away from its shores. ${ }^{39}$ However, the need for emigration was so immense in Malta that London put pressure on Canada and Valletta. Even with the United States open to Maltese immigration, for a time, London saw the Dominions as its preferred destination for its human capital.

In the post-war world, two different stories emerged within the Maltese-Canadian experience. The political narrative was one of denial and exclusion, despite heavy imperial pressure to do the opposite. Exploring the Maltese desire to emigrate to Canada opened a new discussion about the power of empire and Canada's desired place within it. For Great Britain, it remained Canada's imperial duty to work with London on issues deemed critical for the empire.

${ }^{37}$ Barry York, Empire and Race: The Maltese in Australia, 1881-1949 (Kensington: New South Wales University Press, 1990), 100.

${ }^{38}$ Herbert Plumer, "The GOVERNOR to the SECRETARY OF STATE," 22 March 1920. To Secretary of State, Piece No. 88, Malta National Archives, Rabat, Malta.; Joseph Howard, "Memorandum on Emigration to the United States of America," 22 March 1920. To Secretary of State, Piece No. 88, Malta National Archives, Rabat, Malta.

${ }^{39}$ For more on the Winnipeg Strike see, Reinhold Kramer and Tom Mitchell, When the State Trembled: How A.J. Andrews and the Citizens' Committee Broke the Winnipeg General Strike (Toronto: University of Toronto Press, 2010); Knowles, Strangers at Our Gates 134; Library and Archives Canada, Statutes of Canada, An Act to Amend the Immigration Act, 1919. Ottawa: SC 9-10, George V, Chapter 25. Accessed December 1, 2016. www.pier21.ca/reseasrch/immigration-history/immigration-act-amendment-1919 
The exclusion of the Maltese drew considerable attention, and much political angst. The admission of a non-farm labour - the majority of the Maltese seeking entrance -- ran counter to the continental imperial effort of Ottawa, the settlement and economic development of the prairies. On a social level the Maltese continued to build their community and engage in the process of integration without much visible hesitation. The men, and it was mostly men, who came to Canada in 1913 acted as anchors for chains of migrants to find their way into Canada. This meant hundreds would be able to skirt any real barriers to migration in the restrictive era by tapping these migratory anchors. Furthermore, those who did come in the 1920s did so, in their minds, as British citizens moving within the British world. It quickly became a priority for the community to represent its Britishness within the Canadian context.

\section{Political Problems of Emigration}

Many of the imperial complaints against the Canadian policies of exclusion originated in 1922 as the doors of the United States slammed shut. The pinch of immigration destinations was felt strongly in Malta and the complaints lodged with London tended to focus on their unfair treatment within the Empire. As immigration restriction tightened in Canada, a letter written in 1922 highlighted Canada's hypocrisy towards Maltese. Frederick Blair, Secretary for the Canadian Department of Immigration and Colonization wrote to W.L. Griffiths, Secretary of the High Commissioner in London, that due to the new Privy Council amendments to the Immigration Act of 1919, the Maltese migrant would be excluded "if not a farmer or farm labourer. Coming from Malta he would not come within the favoured classes defined in Clause (c) of P.C. 717." However, the situation changed dramatically if a Maltese migrant began his or her journey from England rather than from Malta. If they "succeeded in getting into England P.C. 1041 would not apply because he is a British subject and would be coming from Great 
Britain. Similarly, he would, on reaching England, automatically come within the favoured classes defined in Clause (c) of P.C. 717." ${ }^{40}$ Griffith's response to Blair immediately called out the hypocrisy of the Canadian positon. Noting the difference between direct and indirect migration, and further pointing out the ease Maltese have to enter England, Griffiths wrote, "The fact that a Maltese booking direct from Malta must have a passport and be of the agricultural class, whereas a Maltese who comes to England (which presents no difficulty) and then books to Canada needs no passport and is under no more disability than an Englishman, discloses a peculiar position..."41

Ottawa's denial of Maltese immigrants direct from Malta not only represented a "peculiar position" but came at a moment when Malta's status within the Empire was also changing. A new constitution granted to Malta in 1921 gave considerable measures of self-government to politicians on the island, similar with other "self-governing" communities within the imperial system. Telegrams from the Prime Minister of Malta, Joseph Howard, referenced this exact point. Howard refuted the Canadian ruling that "Maltese immigrants cannot be treated as British subjects from self-governing dominion" because "Malta has been [a] self-governing state since November last. ${ }^{\$ 42}$ Of course the critical word missing in the response from Malta was that of "Dominion." This became the contested issue that played out over the course of the next six

\footnotetext{
${ }^{40}$ F.C. Blair "Letter to W.L. Griffiths," Department of Immigration and Colonization, Ottawa, Canada, September 23, 1922.

${ }^{41}$ W.L. Griffiths, "Letter to F.C. Blair," Office of the High Commission, London, England, October 20, 1922. These Order in Council laws were replaced just months after the writing of Frederick Blair to W.L. Griffiths with nearly equally restricting immigration law. P.C. 185 replaced P.C. 1041 and P.C. 183 replaced P.C. 717. Both allowed fairly open immigration from all white Dominions and heavy restriction against anyone else. Rodolphe Boudreau, "P.C. Council Law," The Governing House at Ottawa, January 31, 1923. Library and Archives Canada: Ottawa, Canada, Department of External Affairs fonds, RG 25-A-3-a Vol. 1327, F. 1090.

42 "Letter to Charles Stewart," Department of Immigration and Colonization - Canada. 13 September 1922. Canadian National Archives, RG 25 A-3-a Vol. 1327, F. 1090. Attached to this document is a telegram which arrives in Ottawa from the Prime Minister of Malta stating "Maltese immigrants cannot be treated as British subjects from self-governing dominion and therefore subject to full regulations PC 717 and will require Canadian Visa on Passport....Malta has been self-governing state since November last.”
} 
years as the issue continued to deepen. The concept of self-governing Dominion was critical to the creation of the image of Maltese migrants as white. The refusal then of Canadian officials to go as far as "dominion" stripped Malta of that luxury. Ottawa was not alone in their confusion on the issue, however. The Colonial Office in London also wrote "that Malta does not enjoy the status of a self-governing Dominion" in a letter to Canadian officials. ${ }^{43}$ Despite Malta's diminished status, Canada informed the Maltese Emigration Office that the Maltese are not aliens and therefore do not require a visa for the entrance into Canada.

The topic of Malta's self-governance remained the critical contention between governments. Despite the islands' self-rule, the diarchy style of government - a local government and imperial government operating on the same level - complicated its claims. The diarchal system was put into place during the Constitutional Crisis of 1921 in Malta. In a nod to the demands of the Maltese citizens, the British divested all matters of local importance to a Maltese legislature complete with a full executive branch. Local elections resulted in local leadership to handle budgets, internal improvements, and other domestic tasks. However, the British government was not willing to forgo complete control, "reserving to itself the exclusive right to legislate with relation to 'matters touching the public safety and defence of the Empire." "44 This meant that the island still housed a British executive branch led by a Governor looking after the defense and military aspects of rule, while often siding with the elected Prime Minister on many domestic issues. However, for outsiders, this was imperial enough for to deny Malta's claim of self-ruled, and their self-aimed "Dominion" status.

\footnotetext{
43 J.E. Featherston, "Letter to Mr. Beaudry," Office of the Minister of Immigration and Colonization, Ottawa, Canada. September 20, 1922. Canadian National Archives: Ottawa, Canada. RG 25 A-3-a Vol 1327 F. 1090.

${ }^{44}$ Ugo P. Mifsud, "Enclosure 2 in No. 16," 11 July 1928, CO 883/8/17, Colonial Office Records, The National Archives - United Kingdom, Kew, England, 31.
} 
In political letters and newspapers, Maltese leaders hoped to assert their full rights due them as citizens of a self-governing Dominion, similar to Canada. Those notices, aimed at London, Ottawa, Canberra, and even Washington, were an insistence from the Maltese that they were and should be henceforth, treated as a Dominion nation. This unrelenting quest to be recognized as something that others did not consider true manifested itself through another letter from Joseph Howard to Canadian Prime Minister Mackenzie King. Howard wrote,

The advice given to the Immigration Department, to which reference is made in your cablegram, that Malta does not enjoy the status of a self-governing Dominion cannot be accepted by my Government, as Malta has under His Majesty's Letters Patent of the $14^{\text {th }}$ April 1921, been granted the Constitution of Responsible Government. Representation to this effect have been made to the Secretary of State who has been requested to advise your Government that the self-governing Colony of Malta should enjoy all the privileges extended to the Governments of British Dominions. ${ }^{45}$

Howard continued that immigration from Malta was a very orderly affair and that the migrants would conform to all the rules and stipulations of the local government. This belief of equality under the eyes of British law, perhaps stemming from a combination of the British Nationality Act, Malta's sacrifices in the War, and their new self-governance was absolutely critical if Maltese were to gain access to immigration pathways.

Howard's next letter, just six weeks later, on December 29, 1922 continued to push the narrative of the Maltese as a European people with self-government within the Empire. This was critical to any perceived success on the Maltese end of emigration. Not only did the Maltese believe they should have some level of equality with Dominions, but also that only by achieving Dominion status would the doors of Empire be fully open to Malta's emigrants. If simple selfgovernment would not convince the other Dominions of Malta's position, then perhaps a self-

45 Joseph Howard, "Letter to Canadian Prime Minister Mackenzie King," Office of the Head of the Ministry, The Palace, Valletta, Malta. October 28, 1922. Canadian National Archives: Ottawa, Canada. RG 25 A-3-a Vol 1327 F. 1090. 
governing, European people of the Empire would have to be emphasized. Howard's December letter sought clarification about the movement of Maltese to and from Canada, particularly the status of those returning to Malta only for a short period of time. He asked in his letter if, "the Maltese settler will receive the consideration that is due to the people of the only European colony in the Empire and to a race that has a glorious history and remarkable national characteristics." Further pushing their claim to equality by pulling on the strings of wartime valor, he added at the very end of the letter that, "the men that can be sent are largely ex-service men and therefore having great and special claims to consideration." ${ }^{36}$

Howard was not alone in his protests. The Governor of Malta, Lord Herbert Plumer, also wrote Ottawa in early 1923 suggesting greater privileges and rights, stating "some special regard is due to Malta not merely in respect of the recognized thrifty and industrious character of the migrants from these Islands, but its unique position as a self-governing portion of the Empire within Europe." ${ }^{47}$ These protests, lodged directly with Canadian Prime Minister William Mackenzie King still did not address the two most pressing issues with Maltese migration from a Canadian perspective - their whiteness and their job qualifications.

In 1924, the dialogue between Ottawa and Valletta began to shift towards the problem of job skills and racial categorization. Malta's new Prime Minister, Dr. Ugo Mifsud, directly

\footnotetext{
${ }^{46}$ Joseph Howard, "Letter to Canadian Prime Minister Mackenzie King," Office of the Head of the Ministry, The Palace, Valletta, Malta. December 19, 1922. Canadian National Archives: Ottawa, Canada. RG 25 A3-a Vol. 1327 F. 1090, 2.

${ }^{47}$ Herbert Plumer, "Letter from Governor Plumer," The Palace, Valletta, Malta. March 28, 1923. Library and Archives Canada: Ottawa, Canada. RG 25 A-3-a Vol 1327, F. 1090, 2; Plumer, CO 883-7-16, pg. 22. Lord Plumer was an ardent support of Maltese equality and it shown through in his many missives and letters to other realms of the Empire. In his 1919 report on the status of the Maltese, shortly after the riots and his coming of Governor, he wrote, "We have reached a point here now when we must either adopt a reactionary policy, i.e., abandon the pretence of letting the Maltese manage their own affairs, and control the Island almost as if it were an "occupied" country, or accord to the people a generous measure of self-government, involving real responsibility for the conduct of all local administration. I cannot imagine for a moment that the former would commend itself to His Majesty's Government and it certainly would not to me, and I strongly recommend the adoption of the latter course."
} 
attacked accusations that Maltese men were not white enough, nor could they handle themselves in a climate such as Canada's. He wrote to Ottawa stating,

I shall not enquire into the grounds on which Malta, which is now a Self Governing State within the Empire - whose inhabitants are of pure European stock and whose physique and staying power, thanks to the geographical position of their country in the middle of the sea and the hilly nature of the land, are comparable to those of any of the Nordic races of Europe - has not been included in the benefits extended under Section (6) para.4 of P.C. Order 183, to other Britishers born in Great Britain and other Dominions. This exclusion brings the migrant from Malta, who is as British as any South African Boer or Canadian Habitant, on the same plane as Italians and other aliens to the Empire.

Prime Minister Mifsud's appeal served two purposes: First, his portrayal of the Maltese as conquered European peoples, not unlike French-Canadians or Dutch-South Africans presented an ultimatum of sorts. Either the Maltese should be afforded the same rights as fellow Europeans under British rule or they should not be considered British at all. The second half of his appeal makes it clear this was his aim. Mifsud argued that alien nationalities were allowed quotas to enter Canada, a far better deal than what the Maltese currently faced. He thoughtfully proposed that Malta could send two hundred skilled laborers and mechanics a year, selected by the Labour Department of Malta under such a quota arraignment. ${ }^{48}$ Canadian Authorities flatly denied this request. $^{49}$

Malta's fight to be included as a Dominion nation, or at least recognized with similar rights to a Dominion nation, had its imperial detractors as well. While the Governor of Malta, Lord Plumer, wrote extensively for Malta's inclusion in the white nations of the empire, his successor, Sir Walter Congreve - despite a love for the people and traditions of the islands - took

${ }^{48}$ Ugo Mifsud, "Maltese Migration to Canada: Memorandum by the Minister for Industry and Commerce," Ministry for Industry and Commerce, Malta. March 6, 1924. Library and Archives Canada: Ottawa, Canada. RG 25 A-3-a, Vol. 1327, F. 1090, 7.

49 W.J. Eqau, "Letter of Quota Rejection,” Office of the Deputy Minister of Immigration and Colonization: Ottawa, Canada. 28 April 1924, Library and Archives Canada: Ottawa, Canada. RG 25 A-3-a, Vol. 1327, F. 1090. 
a decidedly different tone. ${ }^{50}$ In a candid conversation with the American consulate in Malta during a dinner party in 1925, then Governor Congreve stated,

I do not believe it is proper to make any special concessions to the Maltese or to the Egyptians or East Indians; but I would like to be candid and straight forward with them. In the days of Victorian hypocrisy, it was usual to make the assertion that we were in these foreign countries not for our own ends but in order to assist them to become civilized in a modern sense, the "white man's burden" etc.

This attitude in my opinion was very reprehensible for in actuality we are in these different territories because it is in our commercial and political interest to be so.

Why not be frank about it, and say simply: We are here because it is to our advantage to be here and because you can't drive us away. We will do what we like without reference to your wishes, and if, incidentally, our occupation proves to be beneficial to you (and we think that it does, because we are of a superior race) it is so much the better for you! ${ }^{51}$

The quote, and particularly the language used to describe the rule over the colonies, certainly seemed in opposition to the thinking of the Maltese national government but perhaps it was more in line with the attitudes of the colonial officials. If this statement represented a more accurate representation of London's true feelings, then it is no stretch of the imagination to see Canadian unwillingness to bend on the Maltese issue as simply holding the imperial line rather than being an outlier in the commonwealth migration experience.

Although Congreve's statements may have represented one view point in the British government, Malta did have some political backing in the imperial chain of command. Leo Amery, a dedicated imperialist and Secretary of State for the Colonies from 1924-1929, saw Canada's refusal to allow Maltese to settle as an imperial problem. Amery, looking at imperial

${ }^{50}$ Diary of Sir Walter Congreve, 1924-1927, D1057/0/5/4, Staffordshire Record Office - Staffordshire and Stoke on Trent Archive Service, Stafford, England. The diary of Sir Walter Congreve did not contain any direct statements about his feelings on the Maltese people, but rather portrayed them in positive light and his experiences in Malta as overwhelmingly happy and positive, if not political frustrating at times.

${ }^{51}$ Philip Adams, "Survey of the British and Maltese Relations" Malta to the State Department, November 1925, 849B RG 59, Records of the Department of State, NARA II, College Park, MD, 6-7. Consular Adams writes in the preceding that he believes these remarks to be "fairly representative of the attitude of the British governing classes in Crown Colonies." 
issues from a global standpoint, began to argue against discrimination of the Maltese based on the fact that so much of the imperial network relied on an open and British Mediterranean, of which Malta was critical. Writing in 1919 about the working conditions in Malta, Amery lamented that "there is absolutely no reason...for any differentiation between Maltese and British workmen...that the Imperial Government should utilize its position of monopoly as the only large employer of labour in the Island, in order to keep down wages below subsistence level, or to discriminate against its Maltese employees on racial lines." ${ }^{2}$ In the same report, Amery's true feelings on the status of the Maltese as English equals came to the forefront, a position that was evident in all of his later writings to Ottawa and elsewhere. In it he openly declared, "We must give up thinking of Malta as a curious little old-world dependency, living on the outskirts of a British fortress and providing cheap labour for a British dockyard. We must regard it rather as an outlier of the British Isles, flanking the southern shores of Europe as England flanks the northern, and its people as in a very direct and intimate sense our fellow citizens and fellow countrymen." 53 Even if at the core of his being Amery did not believe that the Maltese and the English men were equals, for the good of the Empire it had to be so and he saw that writing on the wall.

For Amery, the accommodation of the Maltese as part of the commonwealth was vital or Britain could face future problems with a rising Italian nationalism in Malta. Viewing Malta as the critical lynch pin in the route to the British East, London could ill afford to lose the naval station to Italy. If Malta continued to be sidelined by the Dominions, it would only encourage the pro-Italian faction. This certainly was on Amery’s mind when he wrote to Canadian Prime

\footnotetext{
${ }^{52}$ Leo S. Amery, "The Financial and Economic Situation," 13 September 1919, CO 883/7/16, Colonial Office Records, The National Archives - United Kingdom, Kew, England, 8.

53 Ibid., 17.
} 
Minister Mackenzie King in late 1923 on the subject of Maltese treatment within the Empire stating,

...the existence of a serious anti-British feeling in a population, which to-day is in the main thoroughly and even enthusiastically loyal, would undoubtedly weaken our defensive position there. Now this exceptional treatment of the Maltese as if they were a coloured people both in Australia and in Canada is a great handle for the pro-Italian faction... Their retention, on the other hand, is not only an undeserved humiliation to a loyal little people but affords a real handle to a small handful of disloyaltists financed by Italy for creating a situation which might some day constitute an actual danger to the Empire. ${ }^{54}$

The rising anger against fellow commonwealth nations, Amery pointed out, came not just from the treatment of Maltese as "coloured people" but also the restrictions against the Maltese themselves. Noted in the letter to Mackenzie King was that Australia only let 260 Maltese a year enter the country while letting a nearly unlimited number of Italians come. For the Maltese, whose most pressing issue was emigration, questions swirled. If being a part of the Empire afforded no advantage, perhaps it would be better to join Italy. This was the sentiment Amery fought against, claiming that British rule made the Maltese considerably better than Italians, and he implored Canada to assist in fighting against the rising Italian threat. ${ }^{55}$

Leo Amery influenced other imperial officials to recognize the long term problems of treating the Maltese as second class citizens. William Ormsby Gore, at the time the UnderSecretary of State for the Colonies, shared his feelings on the subject with Mackenzie King as well. In a letter just days after Amery's November 2, 1923 letter, Gore echoed Amery's statements with a resounding message, stating it "would appear, the Maltese are actually treated worse when seeking to enter Canada than Southern or Eastern Europeans." This was followed

${ }^{54}$ Leo S. Amery. "Letter to Mackenzie King," Admiralty Whitehall, London, United Kingdom, 2 November 1923. W.L. Mackenzie King Papers, Volume 88, File 70189-70191, Canadian National Archives, Ottawa, Canada.

55 Ibid. 
with a lecture on imperial precedent, “...You will not have overlooked the fact that Signor Mussolini has in the past made several very dangerous statements about Italian ambitions with regard to Malta, and of course Malta is vital to us if we are to be the predominant Naval power in the Mediterranean. At present Irredentism is almost negligible in Malta, but if the Maltese are to be treated as pariahs in the self-governing Dominions, one could hardly be surprised if the movement gathered strength. ${ }^{" 56}$ If Canada continued to ignore the pleas of Valletta, and similarly those of London, the future consequence would be great for the entire Empire, or so was the official line.

Despite imploring Canada to aid the empire through immigration reform, Ottawa refused to budge. Amery then employed a new tactic to gain Maltese entry into the Dominions, particularly into Canada, that a British demeanor had been carefully crafted within the islanders over a century of rule. A 1926 letter, once again to King, further implored a change in policy. Amery pleaded;

I cannot help feeling that the specific exclusion of Maltese from Dominions open to other white British subjects is rather hard. They are, after all, white people, at least as white as Southern Italians or even Southern Frenchmen, and having had British administration for a century or more their general sanitary and social standards are considerably above those of the ordinary "Dago". Moreover their Emigration Department really does take a great deal of pains in not allowing people to go out who do not come up to a very reasonable standard both of physique and of education...they do feel very much the way in which they, a small white selfgoverning Colony in the Empire, are treated as if they were a type and standard of race quite unsuitable to form any part of Canada's population. They are, after all, very much like your habitant's [French-Canadians] themselves, very pious Catholics, intensely devoted to their families, which are very large, and quiet docile workers. ${ }^{57}$

\footnotetext{
56 William Ormsby Gore, "Letter to Mackenzie King," November 6, 1923. W.L. Mackenzie King Papers, Volume 88, File 73274, Canadian National Archives: Ottawa, Canada.

${ }^{57}$ Leo S. Amery, "Immigration from Malta - A Case for It," 2 November 1926. Dominions Office Downing Street (London, United Kingdom), Department of External Affairs fonds, IMMIGRATION FROM MALTA, RG 25 A-3-a Vol. 1327 F. 1090, Library and Archives Canada.
} 
This appeal had no real measurable effect on the acceptance of these "white British subjects" into Canada, and it failed to budge written law either. The pressure from Amery, Gore, Lord Plumer, and others revealed the ambiguity of Maltese identity within the empire. For while the Canadians and Maltese held firm to their beliefs on the matter, it was the British themselves who seemed to change dramatically on why the Maltese should be considered good British subjects and the equal to peoples in the Dominions.

The Canadians, for their part, held firm to the view of the Maltese as less than selfgoverning, Dominion peoples from within the Empire. This categorization effectively was all that was needed to bar massive, or even substantial, migration from Malta in the 1920s. For their part, Canadian authorities provided rebuttals for many of the arguments levied against their exclusionary policy. Frederick Blair noted in 1926 that "Maltese emigration to Canada was an old problem," something that began decades ago and proved those who did come never actually settled on the land ${ }^{58}$ Blair continued to counter Amery, Gore, Plumer, and Mifsud, writing that the unemployed of Malta really were not the problem of Canada, and that emigration was not a proper long term solution for the government in Valletta. He later wrote that, "We take the view that if we are to consider immigration from the viewpoint of helping the unemployed, our first duty is towards the Mother Country." 59

But the concept of duty to the Mother Country seemed to run counter to actual experiences. The prime example was the turning away of the Komagata Maru in 1914. The ship, chartered by a wealthy Sikh looking to circumvent Canada's continuous journey ruling, was

${ }^{58}$ F.C. Blair, "Letter to Dr Skelton," The Canadian Building, Trafalgar Square, London UK, November 12, 1926, Department of External Affairs fonds, IMMIGRATION FROM MALTA, RG 25 A-3-a Vol. 1327 F. 1090, Library and Archives Canada.

${ }^{59}$ F.C. Blair, "Memorandum to Mr. Cullen," Department of Immigration and Colonization, Ottawa, Canada. 21 March 1928, Library and Archives Canada, RG 25 A-3-a Vol 1327, F. 1090, 2. 
forced to remain in Vancouver Harbor for two months before the Supreme Court of British Columbia denied the entry of its Indian passengers. ${ }^{60}$ Referencing this international policy blunder, Blair argued that if Canada had never accepted any East Indians, then none would have wanted to come later and thus Canada and India could have altogether avoided the "charge [of] creating ill-feeling as between parts of the Empire." ${ }^{\prime 1}$

This was an old feeling within Canada. For example, in 1908 Mackenzie King, then Secretary of Labour in Canada, travelled to London to make the case against Indian Emigration as good for the whole Empire. In his report back to Ottawa, King wrote that the restrictions on Indian emigration, grounded in humanity and economics, actually "safeguarded rather than curtailed" the "liberty of British Subjects in India." ${ }^{62}$ Furthermore he argued that Canada sought to avoid anything that would paint the nation as insensible to other British Subjects even though they had every right to craft domestic policy as they saw fit. By restricting immigration, it "remov[ed] the possibilities of injustice and friction, [and] is best calculated to strengthen the bonds of association with the several parts [of the empire], and to promote the greater harmony of the whole. ${ }^{\prime 63}$ Therefore, through the issue of emigration from India it is possible to see Canada's concept of duty to Mother Country was limited and self-serving, aiding Britain in a manner which Ottawa felt proper and not necessarily that of London.

When all was said and done, Canadian policy did not change. The view from Ottawa remained that domestic policies crafted in their halls of parliament were done so in a manner beneficial for all of the Empire. In regards to the Maltese migration problem, a final letter in the

\footnotetext{
${ }^{60}$ Knowles, Strangers at Our Gates, 121

${ }^{61}$ F.C. Blair, "Letter to Dr. Skelton," 1-2.

${ }^{62}$ Mackenzie King "Report on Immigration to Canada from the Orient and Immigration from India in Particular,” Ministry of Labour, Ottawa, Canada. 2 May 1908. Rhodes House, University of Oxford, Oxford, England, N. 400.225 r.1, 10

${ }^{63}$ Ibid.
} 
debate of the 1920s told Amery that the Maltese pursuit of Dominion status was an "idle quest." If Malta could not muster up any agriculturalists to send, Canada was "better off with the poor and destitute of Britain." ${ }^{64}$ By the time Blair wrote the last salvo in 1926, Maltese migration was a nearly closed affair. Throughout the course of political bickering, the actual movement of people from Malta to Canada had dwindled to almost nothing. In fiscal year 1924-1925 only a total of 39 people sailed to Canada; of those only 17 were new migrants. That year, as far as the authorities in Valletta were concerned, Canada was all but closed to further migration. ${ }^{65}$ Henry Casolini recognized that Malta was quite powerless in this situation, despite the government's best efforts. He eulogized over Imperial Emigration in his 1926 report, stating that "The fault lies in a combination of circumstances, chiefly a lack of appreciation of our position within the Empire, and, be it frankly admitted, to our ruinous haphazard emigration of the past which permitted a large number of undesirables to find their way into British Dominions." Still, he found some solace in the situation, noting, "it should not be forgotten that as we are masters in Malta, so are Canada and New Zealand and other Dominion mistresses in their own lands, and that in selecting what they deem to be the material best suited to their needs they are within their right." ${ }^{\prime 66}$ With that final musing, migration to the Great White North from the sunny shores of the Malta began a long, almost complete pause before dramatically restarting in the post-World War II years.

\section{A Maltese Community in Toronto}

${ }^{64}$ F.C. Blair, "Letter to Dr. Skelton," The Canadian Building, Trafalgar Square, London, UK. 12 November 1926, Canadian National Archives, RG 25 A-3-a Vol. 1327, F. 1090, 2; F.C. Blair, "Letter to Dr. Skelton, UnderSecretary of State for External Affairs," Office of the Deputy Minister of Immigration and Colonization, Ottawa, Canada. 6 November 1928, Library and Archives Canada, Ottawa, Canada. RG 25 A-3-a Vol. 1327, F. 1090.

${ }^{65}$ Henry Casolani, Emigration Report, 1924-1925. Malta: Department of Emigration, 12 September 1925. Document attached to Consul Philip Adams to Malta to the Department of State, 13 October 1925, 849B.56/16, RG 59, Records of the Department of State, NARA II, College Park, MD, 13.

${ }^{66}$ Casolani, Report on Emigration and Unemployment, 1926, 13-14. 
Despite the diplomatic wrangling, the story of the Maltese in Toronto shares many characteristics with other immigrant communities of the city. Similar struggles such as language barriers, finding niches in the local labor market, and a physical separation from one's family in the old country pervaded the Maltese community. As early as 1916, almost three-fourths of the Maltese in Toronto were single males. Thanks to World War I, many of them were separated from wives and children until, at the very least 1919, when international shipping resumed in earnest. It was in the post-war world that the Maltese community sprouted. Families reconnected and often settled down near other ethnic families, living in the same neighborhood as Syrians, Jews, Italians, and Russians. Yet while many of the Maltese worked similar jobs, went to similar schools, and experienced similar lives with other immigrant groups, there was a major difference in the willingness of the community to connect with "the English." Unlike other immigrant communities, particularly the Italians who exhibited a real aversion to "the English," the Maltese had a long tradition of operating in an Anglo-dominated world. It was this embrace of their "Britishness" while in Toronto that separated the Maltese immigrant from others. ${ }^{67}$ This Britishness, although a major point of contention in policy circles in Ottawa and London, produced a migrant community much more prepared for integration and therefor success in Canada.

The settlement in Toronto traces its origins to the unfortunate experiment of 1912-13, led by Dr. Charles Mattei, the Maltese emigration agent. Some of those whose interests were piqued by Mattei remained, and they took advantage of the opportunity to impress the nation with the skill and work of their race. Others who made the long journey, generally through France to Halifax, worked odd jobs across the Dominion. Joseph Camilleri, for one left Malta in 1913, just

${ }^{67}$ Franc Sturino, Forging the Chain: A Case Study of Italian Migration to North America, 1880-1930 (Toronto: The Multicultural History Society of Ontario, 1990), 173. 
a year after his marriage and shortly after the birth of his son. By fall he had found himself in Toronto working at Hinta Dodge, what he called a good job, one he felt lucky to have obtained. ${ }^{68}$ Other migrants, however, seemed to float from odd job to odd job looking for something permanent before settling down either in Toronto or often in the Canadian Armed Forces with the onset of World War I. These journeys became the typical early migrant experience in Canada, working whatever available jobs existed before finding their way to major urban areas like Toronto.

The First World War played a major role in forming a Maltese-Canadian identity in individuals who fought. Once returned from war, these veterans formed the pillars cementing the chains of migration to Toronto in the following decade. Paul Borg was one of those Maltese who migrated to Toronto prior to the war. Landing in Canada in 1913, the nineteen-year-old found work with the Canadian Pacific Railway, listing his work simply as "Railway man." Towards the end of the war he was one of those Maltese shipped back to Europe wearing the Canadian Army uniform. Living on Widmer Street in downtown Toronto, still working for the CPR, the then twenty-four-year-old Borg was drafted into the Army on January 3, 1918. He spent nearly a year and a half in the military but of that time Borg saw the front lines in France for just ten days. Having shipped out of England on October 10, 1918, Borg was reported wounded and in hospital on October 20. Shot through the left shoulder and suffering wounds to his left ankle and jaw, the young private received care in England before being discharged from military service and back in Toronto on April 12, 1919. But while he served his new country, Borg continued to support his family in Malta, sending a fifth of his income each month, totaling $£ 3.00$, home to his parents. After discharge, and with citizenship in hand, he was free to return to Malta after the war

\footnotetext{
${ }^{68}$ Mr. Joseph and Mr. Vincent Camilleri, interviewed by Richard Cumbo, March 10 \& 29, 1978. Toronto, Ontario, Canada. Multicultural History Society of Ontario Archives, MAL-2855-CAM, Box 128, Maltese C-S.
} 
and be assured of reentrance into Canada. For three months, he stayed in Malta after the war visiting friends and family. While home he married, and later took his new wife to Canada in 1920. Back in Toronto, Borg took a new - higher paying - job with the CPR cleaning rail cars at Union Station. ${ }^{69}$

For others, the war served to separate families, sometimes temporarily and sometimes permanently. The aforementioned Joseph Camilleri never intended to remain separated from his wife for so long. When he migrated to Canada in 1913, the plan was to send for his wife within a year or two of getting a job. With the outbreak of the war, however, that year stretched into six long years of separation. It was not until 1919 that Joseph's wife and son, Vincent, were reunited at Union Station in Toronto. ${ }^{70}$ Although many Maltese men made their first trips to Canada in 1912 or 1913, creating a community of mostly single men in Toronto, other Maltese joined those path blazing individuals in 1919. Naturally with the conclusion of war, those single men like Vincent Camilleri sent for their families to join them resulting in a huge uptick in Maltese numbers across the city, mostly tied to those who had previous connections.

For some, the war served as the stimulus to leave home. Men like Sam Coleiro joined the British Army directly out of Malta and served in Sri Lanka during the war. Sam's experience opened his eyes to the larger world and upon his return to Malta he immediately set about planning to leave. No longer did he care for his homeland. After hearing about Canada through friends, he asked his mother to put up the money for his emigration. With no relations and no one waiting for him on the other side of the Atlantic, he boarded a ship with three friends in 1919 and never returned home. During his eventful, month-long journey to Toronto, he was robbed of all

\footnotetext{
${ }^{69}$ Joan Borg, interviewed by Richard Cumbo, February 19, 1978. Toronto, Ontario, Canada. Multicultural History Society of Ontario Archives, MAL-2848-BOR, Box 137, Maltese B.

${ }^{70} \mathrm{Mr}$. Joseph and Mr. Vincent Camilleri, interviewed by Richard Cumbo, March 10 \& 29, 1978.
} 
of his possessions in Sicily. Once in North America, he worked in northern Quebec clearing forests. Sick of the cold and misery, he left the northlands and headed to the big city looking for any employment that did not require living in the frozen northlands. ${ }^{71}$

In the post-war decade, the Maltese who did come to Canada independent of government schemes, often did so under the guise of being "bona-fide" agriculturalists, much to the frustration of Ottawa. This was a general problem in Canada. By 1921, of the 148,477 new immigrants 62,572 went to Ontario and only 43,822 went to the prairies. Cities like Montreal and Toronto grew rapidly. ${ }^{72}$ This phenomenon was not distinct to the Maltese community, however, as many immigrants used similar entry pathways. Italians in the 1920 s often made an effort to work the farms of Ontario before invariably ending up in cities like Toronto, Windsor, or St. Catharines. ${ }^{73}$ Canadian officials complained vehemently about the use of loop-holes and the fact that migrants showed their inability to "stay on the land."74 Three young Maltese men became prime examples of this unwillingness to stay on the land in early 1923. Vincenzo Cauchi, Salvatore Cini, and Antonio Muscat claimed to enter Canada for farm labor and were "found to have made absolutely no effort to find the places or take the work to which they were supposed to come." ${ }^{, 75}$ Officials found the men working in Toronto and placed them under investigation for

\footnotetext{
${ }^{71}$ Mr. Sam Coleiro and Mrs. Carmelo Coleiro, interviewed by Richard Cumbo, March 13, 1978. Toronto, Ontario, Canada. Multicultural Historical Society of Ontario Archives, MAL-2854-COL, Box 138, Maltese C-S.

${ }^{72}$ Library and Archives Canada. Sixth Census of Canada, 1921. Ottawa, Ontario, Canada: Library and Archives Canada, 2013. Series RG31. Statistics Canada Fonds.

${ }^{73}$ Sutrino, Forging the Chain, 160-161.

${ }^{74}$ W.J. Black, "Letter to Minister Joseph Howard," Department of Immigration and Colonization, Ottawa, Canada. September 8, 1923. Canadian National Archives: Ottawa, Canada. RG 25 A-3-a Vol 1327 F. $1090 / 22$ 610747.

${ }^{75}$ F.C. Blair, “Letter to T.B. Willans,” Department of Immigration and Colonization, Ottawa, Canada, July $11,1923$.
} 
deportation. At least one of those men, Vincenzo Cauchi, remained in the Toronto community

for the rest of his adult life. ${ }^{76}$

Many Maltese either took advantage of a known loop-hole or fell victim to "an

unscrupulous steamship booking agent in Toronto" who promised to write them affidavits and

cover their passage to Canada. Many of these affidavits were blank pages signed by Canadians in

the Toronto area in exchange for cash, generally ten dollars. ${ }^{77}$ What transpired was a diplomatic

headache as eager Maltese would head to France and await passage to Canada, only to be

rejected in France or England by Canadian immigration officials. ${ }^{78}$ The diplomatic and

bureaucratic headaches continued into the late 1920s as well, in the case of Gio Batta Sciberras

and Joseph Cachia. Mr. Sciberras, residing at 557 Richmond Street in downtown Toronto in

\footnotetext{
${ }^{76}$ Voting Records show a Vincenzo Cauchi living in Toronto in 1949 near other Maltese families on the west end. No Vincenzo Cauchi is recorded as having left Canada via steamship towards the UK or Malta during the interim period.

${ }^{77}$ Ibid; W.J. Black, "Letter to Minister Joseph Howard," Department of Immigration and Colonization, Ottawa, Canada. September 8, 1923. Canadian National Archives: Ottawa, Canada. RG 25 A-3-a Vol 1327 F. 1090/22 - 610747. In F.C. Blair's letter to the Special Commissioner of Immigration for Canada, he singles out three people in particular that took part in this affidavit scheme. John E. Doyle of Tottenham, Ontario; Joseph Walsh and Thomas Doyle of Adjala, Ontario. All three signed papers "on the promise of $\$ 10.00$ for his signature." At least in Doyle's case the promise was made to procure a Polish servant girl and Blair notes he had "not received anything but the \$10.00." Blair also notes the Jewish lawyer in Toronto, Lawrence Cohen, securing the affidavits in Toronto would be taken to court by the Ontario Government. Cohen was only part of the scheme however. A steamship booking agent by the name of J.M. Purvis was really pulling the strings. Mr. Purvis would secure signatures of farmers for blank affidavits by attending "public gatherings, such as church services, and under the promise of payment of money."

${ }^{78}$ Ibid.; W.J. Black, "Letter to Sir Joseph Pope, Under-Secretary of State for External Affairs," Department of Immigration and Colonization, Ottawa, Canada. November 11, 1922. Library and Archives Canada: Ottawa, Canada. RG 25 A-3-a Vol. 1327, F. 1090, 2. Black writes in his 1922 letter to Sir Joseph Pope that twenty Maltese who were rejected at Cherbourg, France were done because they were not bona fide agriculturists. He states, "We have had immigration from Malta for quite a number of years and very few of the immigrants who have come have taken up farming; as a matter of fact the Department does not know at the present time where to find in this country a Maltese farmer. This may not be wholly the fault of the Maltese. Naturally Maltese, like others, settle where they can find some of their fellow countrymen and where wages and working conditions are attractive. I think almost all the Maltese in Canada are found in our cities." Furthermore, in 1923 Black writes that, basically, Malta must accept the rulings of the Canadian officials in Europe as they are the mouthpiece of the Canadian government on that side of the Atlantic. Otherwise, if they were poor at their job, or did not represent the most current Canadian law, the expense of keeping officials in Europe would not be worth it for Canada. There is a visible frustration on the part of Mr. Black as he mentions in the previous paragraph that Canada has recently found that Maltese men, admitted to Canada using the same "unscrupulous steamship agent," have never once gone to take up farming but went straight to Toronto. And while they were found guilty, Canada allowed them to stay and try their hand at farming. He finishes that he doubts they stayed long if at all on the farms and are likely back in Toronto again.
} 
1928, received a letter from the Dominion Immigration Agent in Paris stating that his wife had been rejected at the Port of Paris, but the department would let her continue if he could provide a Bond of Indemnity to make sure she would not become a public charge once arrived in Canada. ${ }^{79}$ In the case of Joseph Cachia, he received a very similar letter from Malta notifying him of his responsibilities for a Mr. Lorenzo Cassar and a Mrs. Maria Sciberras, presumably his sister and brother-in-law according to the letter. ${ }^{80}$ These transgressions against the rules and regulations of Canadian immigration policy, well known to Maltese authorities, flew in the face of Maltese governmental promises to take care only to send those who are properly trained and fit for migration. In turn, the response from Canada was a great deal of hesitation when it came to allowing further migration from those sun-drenched islands.

Regardless of the legality of certain migrants, the Maltese busily set about establishing themselves in the local community. During the 1920s, the community began to grow in two different parts of Toronto. The older, pre-war community, was located mostly in downtown Toronto. These people had established roots through the course of the decade since their coming to the city, including a strong congregation at Our Lady of Mount Carmel. Although the church was shared with Irish and German Catholics, it occasionally was serviced by a Maltese priest, Father Cauchi, who resided in the United States. Those Maltese who settled in this area tended to rent their homes. The heads of the households typically arrived in 1913 - creating a stable life for themselves renting homes on streets like Richmond, Adelaide and others before sending for their families. In nearly every case the rented home was split between multiple families or, even more

\footnotetext{
79 “Letter to Mr. Gio Batta Sciberras,” Department of Immigration and Colonization, 9 October 1928, Ontario Provincial Archives, MU 9783, F1405-89-6, SR 5108, Toronto, Ontario.

80 "Letter to Joseph Cachi," Sent from Zaccaria - Valletta \& Victoria Gardens - Sliema, 2 May 1927, Ontario Provincial Archives, MU 9783, F1405-89-9, SR 5108, Toronto, Ontario. The letter states that it is in regard to the emigration of "your mother, sister and brother-in-law" and draws attention to the fact that he is " 1 ) You are ready to stand surely for the immigration of Mr. Lorenzo Cassar; 2) You are willing to offer your services for the purpose of meeting in Canada Mrs. Maria Sciberras as well as Mr. and Mrs. L. Cassar.”
} 
often, between a family and several other migrants, often but not exclusively, other Maltese. Clustering within just a few blocks of Our Lady of Mount Carmel, those who lived downtown tended to reside in this rent-share type situation, which allowed families access to decent housing surrounded often either by native Canadians or migrants from the United Kingdom, as well as a sizeable Russian-Jewish community. ${ }^{81}$

Those who did settle in the downtown community of Toronto often held comparable, if not significantly better, work in comparison to their neighbors. Many worked as general labor at a variety of locations across the city, much like their migrant or native born-Canadian neighbors. A handful of others held more specialized jobs and garnered higher wages thanks to those skill sets. Some worked as butchers and tailors, others as car-cleaners for the CPR, and one even as a city firefighter. ${ }^{82}$ Furthermore, there seemed to be little to no wage discrepancy between the Maltese worker and his fellow Torontonians. In a sampling of census data, the Maltese average wage downtown was roughly $\$ 754$ per year. That average was slightly higher than their two most prevalent neighbors, Jews and Anglos - including native born-Canadians - who brought home an average of $\$ 733$ and $\$ 736$ respectively. ${ }^{83}$ It seems rather evident that through economic assimilation the Maltese achieved future security and prosperity on par with their contemporaries.

The second area of Toronto that became home to Maltese migrants was the new west end suburbs, particularly an area commonly called "The Junction." Those who settled in this part of

${ }^{81}$ A sampling of Census Data from the 1921 Canadian Census highlights the streets and neighbors of the Maltese in Toronto. RG 31; Number 91, Statistics Canada Fonds; Census Place: Ward 4, Toronto South, Ontario, Library and Archives Canada, Ottawa, Ontario.

${ }^{82}$ Ibid., The sampling chosen represents 75 Maltese individuals living downtown Toronto. There is no definitive listing of how many Maltese lived in Toronto during 1921, but considering that only 110 migrants left Malta for Canada in 1920, and that was considered a good number considering the closed nature of Canada, it is likely no more than 500 Maltese lived in Toronto at maximum by the time the Census was conducted. Therefore, this number represents at least one-fifth of the total Maltese population in the city.

${ }^{83}$ Ibid. 
the city often were newer migrants, coming after the War, or were newly reunited families looking to grow in a newer, developing neighborhood. Living on streets like Maria, Vine, Clendenan, Royce (now Dundas), and Gilmour, the Maltese enjoyed a more affluent society than their counterparts downtown. Carmelo Abela was one of those West End Maltese. He first emigrated to Canada in 1917 and picked up work as a general laborer. Although his children had joined him in Toronto, there was no mention of a wife. It is possible she remained in Malta for some time. Regardless, Abela rented a place in "The Junction" on 285 Maria Street where five other Maltese boarded with his family. For those who joined Abela and his household in the West End, the average wage was noticeably higher. Across the neighborhood, it ran nearly $\$ 200$ higher per year, $\$ 932$ compared to an average of just $\$ 750$ downtown, not a small differential in 1921. Likewise, Maltese wages were higher. They earned an average of $\$ 836$ per year. This was the case even though many of those who lived on the west end worked as general laborers compared to the wider ranging and more highly skilled employment found in the downtown community. ${ }^{84}$

Although the community split into two sections of the city and two slightly different skill sets, they shared similar employment opportunities. Regardless of where in the city the Maltese lived, a large portion of men were employed in factory work. The Massey-Harris plant, Canada's largest supplier of agricultural equipment, particularly tractors, or the Swift meat packing plant seemed to be the landing spot for many new Maltese migrants. Those jobs tended to be entry points for Maltese migrants in the greater Toronto economic system. Much like the migration experience itself, the securing of good paying jobs like those at Massey-Harris often benefited

${ }^{84} R G$ 31; Number 102, Statistics Canada Fonds; Census Place: York (Township, part), York west, Ontario, Library and Archives Canada, Ottawa, Ontario; $R G$ 31; Number 79, Statistics Canada Fonds; Census Place: Toronto (City), Parkdale, Ontario, Library and Archives Canada, Ottawa, Ontario. 
from a similar chain-like mechanism. When one individual of an ethnic community was able to make it good at a factory or plant, it often created a positive association with that specific ethnic group at that job site, which naturally made it easier for friends and family members to gain work. $^{85}$

Those Maltese who secured work at Massey-Harris transcended social barriers which often denied fellow Southern European immigrants jobs in factory work. In 1920s Toronto, not only were factory jobs limited but also those that did exist typically went to Germans or AngloCanadians ${ }^{86}$ In certain factories, the Maltese ability to portray themselves as Britishers enabled them to gain access to jobs perhaps withheld from some ethnic groups. With a handful of Maltese employed at Massey-Harris, they operated as anchors in employment chains stretching all the way back to Malta. Once employed, the ability to speak English was the most important consideration to advancement. Considering that many Maltese recalled dozens of their friends and family members working at factories like Massey-Harris or Swift Meats, it appears that the Maltese had success in walking partially in the world of "The English" while maintaining their ethnic identity.

For many in the Maltese community, work in the factories of Ontario represented just a small stepping stone towards a new life economically. Joseph Camilleri joined his brother at Massey-Harris for a few short months in 1927 before lay-offs hit the company. An equally short stint at Swift Canadian preceded his life-long work at Highland Down Paper Company where he worked for 37 years before retirement. Camilleri remarked that many other Maltese also worked at Highland Down Paper Company during his time. Maltese migrants were not stuck in factory work, however. As one might expect, many Maltese found employment - particularly the early

\footnotetext{
${ }^{85}$ Sturino, Forging the Chain, 120.

${ }^{86}$ Ibid., 115.
} 
migrants - within the city's ever important dockyards. Those men likely came to Toronto with experience in the job, as much of Malta's economic opportunity revolved around shipping as well. In addition, several Maltese-run businesses popped up across Toronto in the 1920s. Johnny Azzopardi, an original community member who migrated in 1913, opened a butcher shop in the city servicing both the Maltese community and the wider neighborhood. Other opportunities opened for Maltese men who aspired to risk a new venture in a new land, such as a coal contracting company run by Tony Vella, and several grocery stores. ${ }^{87}$ These private business opportunities opened the door for many other people in the community to find employment as well.

Despite the heavy influence of the Catholic Church and the pressure of traditional obligations on women, many found that North America offered a chance to explore new tracks of employment for women. Maltese-owned businesses, operating within the community, typically sought to employ their own. Particularly those relying upon customer relations looked to hire women. Carmela Camilleri, before she was married, had family obligations that brought her to the east side of Toronto. Her sister and brother-in-law, Josephine and Joe Vella, ran a busy grocery store that required extra help. Grocery stores like the Vellas' or that of Mr. Borg - whose store on Dundas Street and Gilmore was much closer to the community neighborhoods - offered some of the best jobs for women within the community. ${ }^{88}$ But they were not the only positions that were available.

Carmela Cassar obtained work at a Cohen's Chocolate factory. When she arrived in Canada, the woman boarding with her family offered to take her to work and she accepted. Thus

${ }^{87}$ Mr. Joseph and Mr. Vincent Camilleri, interviewed by Richard Cumbo, March 10 \& 29, 1978.

${ }^{88}$ Mr. Francis and Mrs. Carmela Camilleri, interviewed by Richard Cumbo, February 23, 1978. Mississauga, Ontario, Canada. Multicultural History Society of Ontario Archives, MAL-3509-CAM, Box 138, Maltese. 
a chance encounter produced employment for Carmela. The trip to work each day took Carmela down Dundas from her home on Maria Street in the west end, a journey on an unpaved road filled with the smells of pickle juice and the sight of chicken feathers stuck in the mud, all emanating from the Jewish shops along the route, before arriving at the shop on Landsdowne. ${ }^{89}$ Like much of the city, Cassar relied on the growing Toronto public transport system for a portion of her journey, including the famous street cars. Although many of these women gave up public employment for homework when they married, as young women job opportunities existed for those who sought them.

As the newer migrants settled in the city during the mid-to-late 1920s, they sought to create newer Maltese institutions to cater specifically to their community. One of those institutions was an ethnic Maltese parish within the Catholic Church. The attainment of an adequately-sized immigrant community made possible the funding for a church as well as other social activities designed for Maltese migrants. Despite Martin Cachia's recollection of the Maltese as a divided community, evidence suggests those claims may have been a bit exaggerated. ${ }^{90}$ Ties between "The Junction" and Downtown existed and even appeared strong. Even though St. Paul's Maltese Catholic Church opened on the rapidly-growing west side in 1930, the Maltese community across the entire city united at this church, especially during major community events like feast days or other celebrations. The church then represented the center of community social events even if segments of the community lived outside the parish boundaries.

\footnotetext{
${ }^{89}$ Mr. Salvatore (Sam) and Mrs. Carmela Coleiro, interviewed by Richard Cumbo, March 13, 1978. Toronto, Canada. Multicultural History Society of Ontario Archives, MAL-2854-CAM, Box 138, Maltese C-S.

${ }^{90}$ Maria C. Cachia, Martin Cachia, Sylvio Cachia, interviewed by Richard Cumbo, February 10, 1978. Toronto, Ontario, Canada. Multicultural History Society of Ontario Archives, MAL-2847-CAC, Box 138, Maltese C-S.
} 
St. Paul's Maltese brought both "The Junction" and Downtown communities together on many occasions during the year. Some of these were religious in nature, such as visits from Maltese priests. These were always big occasions, giving people the opportunity to say confession in their own language. For those families who welcomed children born around the time of the visits, it was a chance to have children baptized by a Maltese priest. ${ }^{91}$ Other events were not religious at all, like the parties celebrated any time a new Maltese family came to Toronto. Events like these, and many more throughout the religious and secular calendar, formed strong ties between the two communities.

Beyond the Church, the foundation of the Maltese-Canadian Society facilitated the interaction between Downtown and "The Junction." The Society was founded in part by a "great and humble Maltese Monk," Father A. Grech, who preached and urged the Maltese-Canadians to unite in order to pool their resources for the betterment of the entire community. Situated between Dundas Street and College Street near Our Lady of Mount Carmel in the downtown area of Toronto, the new Society aimed to promote integration and assimilation of the Maltese into the Canadian population. A half dozen men, including Anthony DeBatisse who would play a major role in the society over the next fifty years, joined Fr. Grech at a home on Simcoe Street, where Grech placed a single dollar, the Society's first dues, and with that the club was born. ${ }^{92}$ When the constitution was written, the name shifted to the Maltese-Canadian Society of Toronto and had several hundred members by the end of the decade. The Society's own history records its deeds of the 1920s in helping those who moved to the west end of Toronto. Activities included the building of St. Paul's Maltese Parish, helping poor and destitute families, and

\footnotetext{
${ }^{91}$ Mr. Joseph and Mr. Vincent Camilleri, interviewed by Richard Cumbo, March 10 \& 29, 1978.

92 "Maltese march in city streets to mourn Anthony De'Batisse," Toronto Star, March 1971 MU 9783, F1405-89-14, MSR 5115, Ontario Provincial Archives, Toronto, Ontario.
} 
offering assistance to those newly immigrated to Toronto. ${ }^{93}$ Some remembered fondly the plays put on by the Maltese Dramatic Society, with sets built by a Charlie Bonello, who worked during the day as a carpenter with the department store Etons. ${ }^{94}$

As with most things, the existence of social outlets did not guarantee compulsory usage. While the Maltese Canadian Society of Toronto brought many in the community together through a secular medium and offered a helping hand to those who desperately needed it, others like Sam Coleiro found it rather dull and boring. He recalled that at one point he did join the club, but its monthly dues of a dollar were expensive for a young family man laboring in Toronto's factories. Beyond that, he noted that most men just sat around playing cards, not overly exciting for a young man in the process of raising a family. Plus, Sam was one of those Maltese men who, despite living downtown, spent a considerable amount of free time on the west end, where he met a young woman who worked in a Chocolate factory by the name of Carmela, his future wife. ${ }^{95}$ So while the Maltese-Canadian Society of Toronto did a great deal of social good, socializing at the club as a daily habit did not always appeal to the entire community.

Community events, clubs, and other organizations often drew the Maltese together, but Toronto's social life was more than ethnically driven. Shopping in general drew many of the Maltese downtown. The allure of Eaton's shopping center was immense within the region. Its famous Santa Parades began in 1918, and undoubtedly the Maltese made their way downtown to witness the celebration. Eaton's was more than a shopping center, however, it was a cultural and

\footnotetext{
93 "Maltese-Canadian Society of Toronto: Brief Historical Facets of the Society During 50 Years," MCST: Historical Facts, MG 28 VII, Vol. 1., Library and Archives Canada, Ottawa, Ontario, 1.

${ }^{94}$ Mr. Anthony DeBattista and Savarina DeBattista, interviewed by Richard Cumbo, April 12, 1978. Toronto, Canada. Multicultural History Society of Ontario Archives, MAL-2856-BAT, Box 138, Maltese C-S.

${ }^{95} \mathrm{Mr}$. Sam and Mrs. Carmela Coleiro, interviewed by Richard Cumbo, March 13, 1978
} 
social icon for Canadians. Much like Sears in the United States, Eaton's yearly catalog was a must have item for families across the country. With the major shopping center in Toronto, the Maltese were able to indulge in all the basics and luxuries offered by retailer. So important was Eaton's that Martin Cachia recalled folks conflating Eaton's for downtown, “They never used to say we go downtown or are you going downtown? They used to say are you going to Eaton's or we are going to Eaton's. Downtown was Eaton's, Eaton's was downtown." ${ }^{96}$ While the retailer excelled in a range of products, the Maltese also used the store for major grocery purchases. These major purchases supplemented their purchases from the local Maltese or sometimes Syrian vendors who carried their favorite regional treats. With orders filled, often by young sons and daughters who translated Maltese into English and vice-versa for parents and cashiers, the goods were delivered by horse and buggy in the summer or by sleigh in the winter. ${ }^{97}$

The Maltese sought more than mere economic assimilation. Social integration appears to have been just as rapid as their economic integration into Canadian society. In 1921 the Census of Canada records the Maltese referring to their nationality in a unique way compared to almost all other migrant populations. Instead of listing their nationality at "Maltese," they universally are listed as "Canadian." This type of identification remained unique to the Maltese as no other ethnic group was afforded this "Canadian nationality" status. Perhaps this identification comes from the Maltese interaction with the wider Toronto world. Given their small numbers the interaction with the English, in particular, was often unavoidable. Whether living on the west end or downtown, the Maltese always lived as islands of ethnicity on their block. Those living downtown had a greater chance of being neighbors with other immigrants, particularly Jews from Russia or Italians, while those on the west end almost always lived isolated among a

\footnotetext{
${ }^{96}$ Maria C. Cachia, Martin Cachia, Sylvio Cachia, interviewed by Richard Cumbo, February 10, 1978.

${ }^{97}$ Ibid.
} 
neighborhood of Anglo-Canadians and migrants from the United Kingdom. ${ }^{98}$ Whereas the Italians or Jews had the numbers to form isolated communities, existing to an extent without interaction with the wider Toronto world, the Maltese were forced into interaction with their Anglo-neighbors. This, however, was not necessarily received as negative among the community. Endowed with a legacy of Britishness, the Maltese generally thrived in this setting.

Despite all of the political barriers erected against Maltese immigrants, the community seemingly had little difficulty in gaining acceptance from the Toronto populace. ${ }^{99}$ Even in the face of Ottawa's flat refusal to see the Maltese as good, white, British subjects, the Maltese relished their connections to the Empire and their link to the English portions of Canada. By the 1930s, the Maltese proudly boasted about their "Britishness" in letters to the editor and within public forums. The first Maltese Club in Toronto prominently displayed a massive Union Jack along one side of the building, with the Canadian and Maltese flags relegated to lesser positions in the club. Outside of the club building, Joseph Cachia displayed his pride fervently for all to see, recalling that her husband used to fly the Maltese flag right next to the English, Canadian, and American flags at their home. ${ }^{100}$ Though small in number, the Maltese made a significant splash on the social and cultural scene of interwar Toronto.

As a community, this proud British association transcended the walls of its little club, and in 1934 gained the attention of the entire city. Celebrating the centenary of Toronto's founding, the Maltese Canadian Society of Toronto, under the leadership of a committee named the

${ }^{98} R G$ 31; Number 102, Statistics Canada Fonds; Census Place: York (Township, part), York west, Ontario, Library and Archives Canada, Ottawa, Ontario; $R G$ 31; Number 79, Statistics Canada Fonds; Census Place: Toronto (City), Parkdale, Ontario, Library and Archives Canada, Ottawa, Ontario.

99 "as recently as the $5^{\text {th }}$. August, the Most Revd. Mgr. P. Gauci who, at my request, kindly extended his tour from the U.S.A. to Canada, writing from Toronto (Ont.) said "Everyone here speaks most highly of the Maltese, especially the Clergy. I am glad to be in a position to confirm what I already told you in my previous letter namely that our fellow countrymen are everywhere loved and given preference, because they are good, religious and conscientious workers." 99 Casolani, Report on Emigration and Unemployment, 1926, 20

${ }^{100}$ Maria C. Cachia, Martin Cachia, Sylvio Cachia, interviewed by Richard Cumbo, February 10, 1978. 
"Knights of Malta Committee," entered a float in the city parade. Attached to the side was a shield, colored red and white for Malta, reading, "Malta, The Last Home of the Knights of St. John.” Standing atop the float were a dozen men and women dressed in various costumes from a Knight of Malta, to British sailors and some in traditional Maltese dress. But the centerpiece were two young ladies, one dressed as the "Melita," the spirit of Malta, carrying the Union Jack with a sash reading "Malta" across her chest, and the other dressed as "Britannia" complete with the standard Union Jack shield and trident. This wonderful display focused on the combined British and Maltese heritage of the islands. ${ }^{101}$ With great pride it took home the first-place prize for best float in the parade. Most importantly, it showed that the Maltese decisively cast their lot as Britishers within Canada. And while they advanced their own Maltese-specific ethnic institutions the integration into "English Canada" far exceeded that of fellow southern Europeans.

What the evidence suggests is that attempts to keep the Maltese out of Canada were based upon a loose idea of who qualifies as a "British Subject" across the empire. Defined one way in Canada, another in Malta, and yet another in England, these disagreements made the Maltese a special, although difficult imperial people. Even when the Canadian economy picked up steam in 1922, there was a refusal to see the Maltese as "Britishers," as noted by historian Barry York. He wrote, "It is difficult to fathom why the Canadians went to such lengths" to exclude the Maltese. ${ }^{102}$ The logical explanation, that despite the insistence of the British government on the racial makeup of the Maltese, the Canadians could not remove the Maltese from their Southern European origins regardless of British colonization. Canada sought their

${ }^{101}$ Richard S. Cumbo, "Two MCST children, one dressed as "Melita" and the other as "Britannia" during Toronto's cent. 1934," submitted 3 February 1978, 28-02 MSR 4927 - 4, No. 3762, Photograph 7, Archives of Ontario, North York, Ontario, Canada.

102 York, Empire and Race, 107. 
exclusion based on race alone, using racially disguised language to get the job done. Evidence exists in the crafting of the 1919 amendments. With all of this political wrangling swirling overhead, what happened on the ground was rather remarkable. The Maltese continued to come and settle in Canada despite political protests against their being there. Not only did they settle in Canada and their numbers steadily grow in places like Toronto but also they achieved success in their new homelands. They built community clubs, churches, businesses, and lives. The Maltese thrived in Toronto, and relished their opportunity to exhibit their successes as Maltese, as Britishers, and as Canadians. Therefore, Imperialism played a complex role in migration for the Maltese. It both hindered their movement to Canada, and helped them rapidly assimilate into a new nation. 


\section{Chapter 5 - Maltese in Detroit}

"It wasn't always easy, living in the land of plenty."

Rose Mifsud

Detroit. It was one of those magical places in the 1920s that migrants from all over the world dreamed about. Rising majestically on the banks of the Detroit River, spilling over into Canada in the form of Windsor, the cities combined to form the industrial heart of North America. Its massive factories belched smoke up and down the riverfront while new art deco skyscrapers reached further and further above the haze. The so-called "Paris of the Midwest" featured broad tree-lined avenues and cosmopolitan charm. By 1920, Detroit was America's fourth largest city, and people from all over the country travelled to the city for shopping, arts, and entertainment. It was a strange new world. Modern industry became the harbinger of previously unfathomable luxuries. It was, in most respects, a dream.

Vincent Vassallo was one of those starry-eyed migrants. His journey typified the route migratory men attempted to make during the era of restriction starting in 1921. With a trip paid by his mother, Vassallo travelled first to Canada in 1920 looking for work as a farm laborer. While in Canada, he began formulating his plan to enter America. That plan hit a snag. In November 1923, he was deported from the United States after attempting to land in Philadelphia as a stowaway. Yet, just a month later he travelled from his home on Dundas Street in Toronto to Detroit. This time, he simply visited friends living downtown on East Congress Street, likely for the celebration of New Year's Eve. His brief visit in Detroit sparked a life-long desire to return to America. Vassallo returned to Canada once again but in August 1924 he left Montreal and crossed through Liverpool on his return to Malta. Still his determination to end up in America

\footnotetext{
${ }^{1}$ Interview with Rose Mifsud, interviewed by author, June 1, 2016, Farmington Hills, Michigan.
} 
persisted. After remaining in Malta for several years, the twenty-five-year-old landed a job working aboard a transatlantic steam ship as a chef's assistant and found himself once again in the United States. ${ }^{2}$ Vassallo's ping-pong like experience across the Atlantic represented an alltoo common Maltese experience as they probed the United States for several years via Canada and other methods before finally entering and settling in America.

While Detroit drew hundreds of thousands of immigrants, the Maltese migration was an outlier of movements of people in the immediate post-war years. These migrants entered the United States, bound for the Motor City, and were unlike the typical Southern European migrant of the era. They even differed in many respects from their brethren entering Canada at the same time. Massive layoffs at the Royal Dockyards in the aftermath of war left Malta's working class crippled, leaving thousands of skilled laborers unemployed. Coinciding with this reduction in Malta's workforce was the rise of Detroit's automobile factories and the associated industrial accoutrements. Looking for industrial work to match their skill sets, thousands of Maltese flooded into Michigan during a very short period between 1919 and $1921{ }^{3}$ Then, in 1921, new national quota restrictions dramatically halted that movement. This chapter explores how, unlike

\footnotetext{
${ }^{2}$ Library and Archive Canada; Form 30A Ocean Arrivals (Individual Manifests), 1919-1924; Rolls: T14939 - T-15248; The National Archives at Washington DC; Series Title: Passenger Lists of Vessels Arriving at Philadelphia, Pennsylvania; NAI Number: 4492386; Record Group Title: Records of the Immigration and Naturalization Service, 1787-2004; RG 85, Series T840; Roll 151; Series Title; Card Manifests (Alphabetical) of Individuals Entering Through the Port of Detroit, Michigan 1906-1954; NAI 4527226; RG Records of the Immigration and Naturalization Service, 1787-2004; National Archives (UK) Kew, Surrey, England; Year: 1929; Arrival: Southampton, England and Cherbourg, France; Microfilm Serial: T715, 1897-1957; Microfilm Roll: 4495, Line: 23, Page, 80; Board of Trade: Commercial and Statistical Department and successors: Inwards Passenger Lists; Class BT26; Piece 760, Item 72.

${ }^{3}$ In many respects the Maltese case of industrially skilled labor migrating abroad for better employment was not a new phenomenon. Skilled laborers from Belgium, in industries such as glass and textiles, sought out the United States at the turn of the century for higher wages. These Catholic skilled laborers mirrored the Maltese experience, with the major difference being the timing of their migration, Maltese coming after World War I and during the exclusionary era. For further reading see: Ken Fones-Wolf, "Transatlantic Craft Migrations and Transnational Spaces: Belgian Window Glass Workers in America, 1880-1920," Journal of American Ethnic History, Vol. 21, No. 2 (Winter, 2002); Gary Gerstle, Working-class Americanism: The Politics of Labor in a Textile City (New York: Cambridge University Press, 1989).
} 
in Canada, Maltese status as "Britishers," combined with their social success in Detroit, allowed them room to negotiate their quota status. While not an immediate success, by 1925 they were granted a categorization under the British quota, a move that transferred the issue of migration from the halls of Washington to London. With a greater opportunity for migration, along with a much larger population base in Detroit compared to Toronto, the chapter also tracks in greater detail how the community's social development helped open the doors of immigration even further.

Unlike Maltese who moved to Canada in the immediate post-war years, the Maltese who migrated to the United States faced much different prospects. Migration into the United States for the Maltese proved far easier than to Canada. As noted in the previous chapter, the imperial connections of Malta and Canada hindered rather than helped Maltese who wished to migrate to Canada. In the United States, the Maltese were British subjects and good European ones at that. Thanks to an allotment under the British quota, the Maltese were able to far exceed the numbers they should have been allowed given their backgrounds as southern European Catholics in the era of immigration restriction. Because Maltese migration to America occurred in steady, albeit small numbers initially, the political pressure so prominent in the story of Maltese migration to Canada was less prominent here. One major reason politics took a back seat in the migration story to the United States revolved around who settled in Detroit and the type of community that developed. The number of skilled men who began to work in the city of Detroit and laid down roots exhibited a type of migrant that was easily transitioned into American culture and the local industrial economy. Therefore, pressure to keep these migrants out of the country was almost non-existent. 
As urban areas boomed with immigrant labor in the earliest parts of the twentieth century, assimilation was key to being classified as "good immigrants." In Detroit, the automobile industry provided thousands of jobs for immigrants, which led to the meteoric rise of the city's population. The 1920 United States census showed a majority of people living in America resided in cities for the first time, with the bulk of this population coming from America's rural regions and foreign countries. ${ }^{4}$ The Maltese became part of this growth, setting their sights to the global west and, by the early 1920's, gained a foothold in America's industrial heartland.

Unlike Canada, whose immigration policy targeted developing its natural resources by directing immigrants to the prairies to clear and settle, the United States' demand for labor was heaviest in large industrial factories. Thus, migration to the cities was an integral part of the U.S. economic progress. There, modern corporations had an almost insatiable demand for labor. The inner cores of the emerging urban areas provided a necessary function for immigrants moving to the United States. Central neighborhoods offered both shelter and jobs which helped to ease the stress of moving into their new lives. Within the inner city, ethnic neighborhoods emerged in the 1880 's as a mechanism to lessen the shock of moving to a foreign nation. For a new immigrant, these neighborhoods contained familiar people from the homeland and familiar traditions as well, welcome sights amidst a world of new experiences. As the old families became more familiar with the landscape of the city and perhaps gained better employment, they began to move out to other districts of the city, sometimes closer to their places of employment. ${ }^{5}$ To

\footnotetext{
${ }^{4}$ U.S. Bureau of the Census, "Demographic Trends in the $20^{\text {th }}$ Century, 2002" under "Total Population, Population Change, and Population Ranking for the Ten Largest Cities in the United States: 1900 to 2000 ," www.census.gov/prod/2002pubs/censr-4.pdf (accessed March 30, 2012). Howard P. Chudacoff and Judith E. Smith, The Evolution of American Urban Society, $5^{\text {th }}$ ed. (Upper Saddle River, NJ: Prentice-Hall, Inc., 2000$), 118$.

${ }^{5}$ Howard P. Chudacoff and Judith E. Smith, The Evolution of American Urban Society, $5^{\text {th }}$ ed. (Upper Saddle River, NJ: Prentice-Hall, Inc., 2000), 145. This can be seen easily with the Detroit Maltese community as well by looking at the census data of the 1920s, 1930s, and 1940s. Those Maltese that migrated in the 1910s are
} 
many, the movement of old families out of ethnic ghettos and neighborhoods symbolized the peak of Americanization.

The rapid growth of America's urban centers sparked friction between immigrant communities and the native-born communities. What sparked this movement towards nativism was the influx of millions of Italians, Greeks, Russians, and others who had immigrated to the United States between 1880 and 1920. The 1920s anti-immigration laws passed in backlash to this migration took on a flavor developed specifically from the American Protestant fear of the Catholic, Orthodox and Jewish peoples. ${ }^{6}$ Italian and Slavic individuals living in ethnic ghettos across American cities were visibly poorer than most Americans, and thus a connection was made by the American populace between new religious groups and poverty, thereby fueling restrictive policies. ${ }^{7}$ Religious discrimination blended with the pseudo-science of eugenics sweeping through Anglo-American and Anglo-Commonwealth nations. The “white man's burden" now stretched itself to cover even those of European heritage, shaping the people from the "Latin" and "Slavic" nations as incapable of self-government and poor candidates for assimilation. This resulted in grouping Italians, Greeks, Poles, and Russians, alongside Mexicans, Asians, and Africans. ${ }^{8}$ These connections played a role in the minds of congressional members who passed the Immigration Acts of 1921 and 1924 which restricted migrations from southern and eastern Europe by enacting quotas for the population. ${ }^{9}$

\footnotetext{
found to be living in middle class neighborhoods by the 1920 census. By 1930, although the bulk of Maltese lived in the Corktown area of Detroit many more were beginning to spread throughout the city. Finally, by 1940 most of the established Maltese families had relocated closer to work places or to better neighborhoods.

${ }^{6}$ David A. Gerber, American Immigration: A Very Short Introduction (Oxford: Oxford University Press, 2011), 37.

${ }^{7}$ Schrag, Not Fit For Our Society, 47.

${ }^{8}$ Peter Schrag, Not Fit For Our Society: Immigration and Nativism in America (Berkley: University of California Press), 84.

${ }^{9}$ Immigration Act of 1924, Public Law 139, Sec. 4-C, H.R., (May 26, 1924), 155.
} 
The nativist fears took root not just in legal precedent but on the ground as well. The rapidly expanding cities of the country sat on the edge of social strife. Just as the Maltese began settling into Detroit in 1920, tensions throughout the city escalated. A rising murder rate and Anglo-Saxon nativism led to anti-Semitic, anti-black, and anti-Catholic movements that were just some of the social problems. With the population booming, reaching nearly a million people, the city was overcrowded and fielded a police force unlikely to exhibit fairness in the eyes of the law, causing a city-wide divide. ${ }^{10}$ This fracture came to the forefront in the 1924 mayoral race. Charles Bowles, backed by the Ku Klux Klan (KKK) and Henry Ford squared off against the Polish-Catholic Democrat John Smith. As the KKK marched through the streets, Smith used Catholic Churches to deliver his message. Speaking to a crowd at the Polish St. Stanislaus, Smith declared that Klansmen, "have robbed Catholic churches and attempted to burn them, they have tortured and slain Negroes and Jews." 11 The ability to unify the Catholics communities along with the black community solidified a strong and populous voting block for Smith, who used these populations to secure victory. ${ }^{12}$

Despite these tensions and national anti-immigration laws, Detroit was well on its way to becoming "the greatest of all manufacturing capitals," with half of its work force employed either directly or indirectly in the auto industry. ${ }^{13}$ Led by industry giants such as Chrysler, Ford, and General Motors, the auto industry sprouted in Detroit at the start of the new century. This industry required a massive influx of labor, and like many other northern industrial cities, Detroit filled with foreign born and black migrants who very quickly outnumbered the native-born

\footnotetext{
${ }^{10}$ Kevin Boyle, Arc of Justice: A Saga of Race, Civil Rights, and Murder in the Jazz Age (New York: Macmillan), 104; 137.

${ }^{11}$ Ibid, 143.

12 Ibid.

${ }^{13}$ Carl Abbott, Urban America in the Modern Age, 1920 to Present (Arlington Heights, Ill: Harlan Davidson, 1987), 11.
} 
population. ${ }^{14}$ The city's population of just 285,704 at the start of the century was not even large enough to include it in the top ten cities of the nation; however, within just two decades the population tripled. By 1920 Detroit was home to 993,678 people and was the fourth largest city in the United States. One of the many factors that fueled immigrant desires to go to Detroit was the radical idea of earning a fair wage for a day's work. The impact of Henry Ford's $\$ 5$ per day wage was more hype than actual reality, but the advertised higher wages drew migrants who knew little about the cost of living in Detroit. ${ }^{15}$ Immigrants, hearing from relatives who already made the journey or through news stories, knew that in Detroit they could make a decent living. The Maltese joined a hodge-podge of ethnic groups, including Canadians, making the short trip across the river, as well as Italians, Russians, Mexicans, and more who made far longer treks.

\section{Economic Need and the Political Will for Detroit}

Maltese emigration to Detroit differed from almost any other migrant experience in the United States and certainly for any other Maltese migration destination. The skilled labor set that many - although not all - Maltese carried with them to Detroit made a world of difference. They did not move to the city simply because it was a large urban area where migrants might find any job, similar to New York or Toronto, but rather for the specific purpose of using the skills obtained in Malta's shipyards to their advantage. Because of their initial success an anchor of migration was set. The Immigration Acts of 1921 and 1924 caused unintended hardship on the Maltese. Their emigration to Detroit, temporarily halted, resumed slowly under Imperial pressure. Through it all, their movement was never as contested as their countrymen's attempts to land in Canada.

\footnotetext{
${ }^{14}$ Boyle, Arc of Justice, 3.

${ }^{15}$ Steve Meyers, The Five Dollar Day: Labor Management and Social Control in the Ford Motor Company, 1908-1921 (Albany: State University of New York Press, 1981).
} 
Prior to the 1919 and 1920 migrations, a handful of Maltese made the move to Detroit, establishing a base which later immigrants built on. In many cases, these early Maltese emigrants were either Maltese-English or native-born Maltese with British spouses. Overwhelmingly, they also owned their homes rather than rented, a sure sign of economic security for many just ten years or less into their lives in the United States. One of the earliest migrants from Malta was Edmond Dowdney, who was a Malta-born Englishman, He and his wife Isabella migrated to America in 1884. By 1920, their children and grandchildren lived with them in their family home on $16^{\text {th }}$ Street in Detroit. Edmond held a job as a clerk and his sons worked as machinists in the city. Being an English born Maltese, Edmond and his family easily assimilated into the Anglo dominated American culture, likely shedding any association with the Maltese. The assimilation of this early migratory family was complete; Edmond and his wife were the only migrants living in close proximity to the family home. ${ }^{16}$

Joseph Borg was another of those early migrants who assimilated quickly. Though he was fully Maltese, he married an English woman and moved to Detroit in 1910. His wife made her trip across the Atlantic four years later, and by 1918 the couple had become naturalized citizens of the United States. Though he and his family started out in Midtown Detroit, by 1920 they had moved closer to Highland Park, where Joseph had just a short commute to his job as a toolmaker at a Ford Motor Company plant on Manchester and Woodward Avenue. The Borg family had 2 young children, both born in Detroit, and appeared to enjoy a comfortable life. Like the Dowdney family, the Borgs were another family surrounded almost completely by nativeborn Michiganders. ${ }^{17}$

\footnotetext{
${ }^{16}$ National Archives and Records Administration, Year 1920; Census Place: Detroit Ward 10, Wayne, Michigan; Roll: T625_809; Page: 6A; Enumeration District: 310; Image: 806.

${ }^{17}$ National Archives and Records Administration, Year 1920; Census Place: Detroit Ward 15, Wayne, Michigan; Roll: T625_814; Page 4A; Enumeration District: 78; Image: 892.
} 
What pushed the Maltese to seek new employment overseas was a complete collapse of their domestic economy. Controlled by the Imperial government whose dockyards were the main employer on the islands, a drawdown of the work force in the post-war years resulted in miserable levels of unemployment. Those who decided to stay, perhaps hoping for an economic turnaround, witnessed nothing of the sort. Layoffs at the dockyards pushed the number of unemployed Maltese men upward to 15,062 by March 1920; over 10,000 were former dock workers. ${ }^{18}$ Further layoffs loomed and the cost of living kept rising. ${ }^{19}$ For those recently let go from work, the double-edged sword of rising costs and no income pushed many who had the means to embrace migration. ${ }^{20}$ The relationship between union action, touched on in the previous chapter, and emigration was important. It was only when labor negotiations failed dramatically that skilled Maltese laborers flooded off the island.

The migration did not occur haphazardly, but rather in a controlled process. Amid rising turmoil, both London and Malta initiated a long-planned emigration scheme designed to relieve island unemployment for moments exactly like what had occurred. The use of emigration as a safety valve aimed first for temporary relief. ${ }^{21}$ One simple option existed: reconstruction work in war-torn France. In 1919 Malta prepared to send nearly 7,000 workers to operate "absolutely on

18 Howard, Report on Emigration, 1918-1920, 137. Dock-workers would encompass a wide range of positions within the harbor including men who worked in the drydocks as skilled craftsmen, men who simply worked as unskilled labor on the wharf, and even those who would have worked in administration positions.

${ }^{19}$ Carl R Loop, "Emigration from Malta to the United States," Malta to the Department of State, 10 April 1920, 849B.56/4, RG 59, Records of the Department of State, NARA II, College Park, MD, 1.

${ }^{20}$ Coupled with the increasing lay-offs, the Maltese government cut sugar rations to " $2 / 5$ of a pound per person per week" in June of 1920 and reduced government subsidy for bread in half from "about £3,000 (\$14,600) per week" to no "more than $£ 1,600(\$ 7,786)$ per week." Carl R Loop, "Reduction of Bread Subsidy in Malta," Malta to the Department of State, 28 August 1920, 849B.50/1, RG 59, Records of the Department of State, NARA II, College Park, MD; Carl R Loop, "Sugar Ration in Malta," Malta to the Department of State, 19 June 1920, 849B.50/-, RG 59, Records of the Department of State, NARA II, College Park, MD.

21 Lawrence Attard uses the term "safety valve" prominently to describe the way in which emigration was used in Malta during times of economic distress and high unemployment. 
par with French labour."22 This was the first test of sending Malta's skilled labor force abroad, hoping to not only put a "best foot forward' for future migrations but also in hopes of permanently settling individuals away from Malta. The trend of sending a majority of Maltese skilled labor abroad continued, one that troubled the island regardless of the migrants' final destinations. Yet despite the best intentions of the agreement with the French, it appears that only 624 Maltese men signed contracts. By early 1920 the French government had drifted away from the strategy of hiring foreign labor for rebuilding the nation. Furthermore, those who left Malta for France found only temporary relief before they again faced a difficult decision: return to a life of unemployment in Malta or proceed to America for work. ${ }^{23}$

That same year, frustrations over the economic conditions in Malta and the absolute need to emigrate began to appear in the Maltese press. The Malta Herald ran an article which questioned the massive dock layoffs and lamented the growing outmigration to the US.

With our fleet in the Mediterranean more powerful than it has been for years past, it would appear to be obvious that Malta Dockyard must be kept in an efficient state at all costs. Yet the Admiralty started discharging skilled men at the first opportunity, apparently forgetting that Malta is an island and does not contain a dozen shipyards.

The result is obvious: the men preferred emigration to America to starvation, and the Americans were very glad to pay big money for skilled labour of this sort. Now the discharges have been stopped and every effort is being made to discourage men leaving voluntarily. But the damage has been done, and, attracted by the reports of their relatives in the States, men are leaving in shoals. ${ }^{24}$

22 Joseph Howard and Joseph Zammit, Report of the Malta Government Delegation to the French Government in connection with the employment of Maltese on Reconstruction Work in France, $15^{\text {th }}$ Sept. 1919, Malta: Government Printing Office, 15 September 1919, Document attached to Consul Carl R. Loop to Malta to the Department of State, 8 October 1919, 849B.56/1, RG 59, Records of the Department of State, NARA II, College Park, $\mathrm{MD}, 4$.

${ }^{23}$ Joseph Howard, Further Report on Emigration, 1920. Malta: Department of Emigration, 28 October 1920, Document attached to Consul Carl R. Loop to Malta to the Department of State, 27 November 1920, 849B.56/6, RG 59, Records of the Department of State, NARA II, College Park, MD, p. 3.

${ }^{24}$ Carl R Loop, "Emigration from Malta to the United States," 1. 
Despite efforts to keep labor on the islands, the Royal Navy continued to reduce its tonnage and the island kept hemorrhaging its most skilled industrial workers. Eventually, dependence on the British war machine meant economic disaster in a colony with no alternatives. Leaving their homeland became the best option for many skilled and unskilled laborers.

For the Maltese who went to Detroit in 1919 and 1920, leveraging their skills paid large economic dividends. Skilled labor in the city commanded a wage of roughly $\$ 7.50$ per day, compared to $\$ 5.52$ for unskilled work. The migrants who made it to Detroit did so with that destination specifically in mind. As the British Admiralty drew down the work force at the dockyards, one of its great complaints was that the Maltese laborer knew what he was worth and only the wages in Detroit would satisfy them. ${ }^{25}$ Additionally, the Emigration Department preselected only those emigrants who would stand an honest chance at success for visas. In a 1920 report issued by the Maltese government, out of 1,377 applicants for migration to the U.S., only 321 were classed as "unskilled." 26 The report also noted differences between Canada and the U.S., explaining that over 40 percent of migrants intended for Canada were unskilled because of a sharp demand for farm laborers there, while less than 20 percent of those headed to the U.S. were unskilled. Furthermore, those who had previously gone to Toronto now "directed their steps to Detroit." Many followed the "prevailing conditions of the labour market ... where he could turn his expert training to advantage" in the burgeoning auto capital. ${ }^{27}$ These pioneering migrants of 1919 and 1920 set about unpacking their imperial understanding to establish a familiar dual-world system for their brethren to come. ${ }^{28}$

\footnotetext{
${ }^{25}$ Brian Barttelot, "Rear Admiral Barttelot to SECRETARY OF STATE, Malta," 31 March 1920. To Secretary of State, Piece No. 94, Malta National Archives, Rabat, Malta.

${ }^{26}$ Howard, Report on Emigration, 1918-1920, 6.

${ }^{27}$ Ibid, 5.

${ }^{28}$ Within a year the immigrants had established the Maltese Association of Detroit in order to centralize business and general affairs. Hoch, "Pride of the Maltese." The Detroit News, January 13, 1926.
} 
Not only could skilled Maltese labor earn more in Detroit, but they also had the greatest chance of workplace success, including advancement and longevity. Coming to the city with industrial skills and previous experience in Anglo-run industry, Maltese immigrants also fit into the union scene of the city. Union activism grew rapidly in Detroit as industry expanded. AngloGaelic migrants, particularly tradesmen from the United Kingdom who were fleeing their homes, headed to Detroit due in part to an unprecedented economic downturn in 1921. This Anglo migrant wave, the last major migration of British individuals to the United States, drove early unions in Detroit as they came to the city understanding industrial trade unions back home. These migrants became the root of union activism in Detroit in the Great Depression. ${ }^{29}$ While the Maltese immigrant played only minor roles in the union activity given their small community size, their previous experience with industrial unions gave them yet another edge in the city. Coming from the Dockyards of Malta, where the Imperial Government Workers Union (IGWU) and other nascent labor organizations from Britain operated, the Maltese worked within an increasingly unionized workplace and had a level of familiarity not afforded other, more rural, migrants. $^{30}$

The recruitment of Maltese by both foremen and relatives to work in the auto industry drove the engine of migration to Detroit. In total, ten thousand immigrated between 1918 and

${ }^{29}$ Steve Babson, Building the Union: Skilled Workers and Anglo-Gaelic Immigrants in the Rise of the UAW (New Brunswick: Rutgers University Press, 1991), 68-70. Babson highlights the mass emigration of UK industrial workers experiencing economic shuttering in their homes in the midlands and north of England. Much of this story is echoed with in the experiences of the British Subjects from Malta who also experience heavy economic downturn. They, like their counterparts in the Midlands and Scotland, moved to Detroit particularly if they had experience as machinist and metalwork.

${ }^{30}$ Godfrey Baldacchino, “Trade unions in Malta," Report 110, European Trade Union Institute (Brussels: ETUI Printshop, 2009), 17-18. Baldacchino outlines what he calls the "First Epoch" of Maltese union activism lasting from the earliest nascent union, the Fitters' Union as early as 1884 through the 1920s. While these early unions faced backlash from the Catholic Church and were often outlawed, unions continued to affiliate with others based in Britain. These unions consisted of "establishment of small, craft- or trade-based affiliations, organising either relatively unskilled workers or specific grades in the public service." In 1921, the Trade Union Council was established in Malta. 
1920. This number preceded the incredible growth in numbers during the first four months of 1920. In those four months, leading up to April 29, a total of 3,461 emigrants either were issued passports or put their names in for the issuing of passports to go to the United States. The majority of those undoubtedly settled in Detroit. ${ }^{31}$ In all, nearly 14,000 Maltese planned to move to the United States within a two-and-a-half-year period. A weeding out of migrants unable to succeed by Maltese authorities and those migrants who may have stayed in New York City or proceeded west to San Francisco reduced the number of migrants who ended their journey in Detroit. Yet by 1920 a sizeable population of over 5,000 Maltese, likely half - or more - of all Maltese in the United States, made their home in the city. ${ }^{32}$ The community that made it to Detroit settled in the Corktown district of the city. A 1922 Detroit Free Press article claimed that this grouping of Maltese was the only "colony" of mentionable population of Maltese in the United States. ${ }^{33}$

In Detroit these new migrants clustered together based on occupational categories. Once established, they sent for their families and relatives. One group of six Maltese rented a home with a native-born American family on Fourth Street in Corktown. These six individuals all migrated to the United States in 1919 and worked as carpenters across the city in shipyards, in housing, and in auto factories. ${ }^{34}$ Other 1919 migrants like Paul Farrugia, George Cillia, and Joseph Gauci, all boilermakers at the shipyards, rented their own home on West Lafeyette, taking in boarders. ${ }^{35}$ But the most common factory positions found among the community were those of

\footnotetext{
${ }^{31}$ Lawrence E. Attard, The Great Exodus: 1918-1939, Ch. 4, sec. 1. Attard notes that 2,193 emigrants were issued passports directed towards the United States. They were not alone, over those same four months the over twothousand emigrants were joined by 1,268 others who sought the same passage.

${ }^{32}$ George Graff, The People of Michigan (Lansing: Michigan Department of Education, 1974), 131.

33 "Malta Provides Detroit with Big, Efficient Colony," The Detroit Free Press, August 8, 1948.

${ }^{34}$ Year 1920; Census Place: Detroit Ward 4, Wayne, Michigan; Roll: T625_805; Page: 10B; Enumeration District: 122; Image: 406.

${ }^{35}$ Year 1920; Census Place: Detroit Ward 6, Wayne, Michigan; Roll: T625_806; Page: 3B; Enumeration District: 183; Image: 38.
} 
machinist or tool-and-die maker. The prevalence of these positions and the mixed homes where many unrelated Maltese lived together suggests that these men were called over by friends and relatives prior to 1919. They then migrated with friends from Malta who may have held similar positions and took comparable employment upon arriving in Detroit.

Emmanuel Muliett represents a very typical migration experience. In 1919, the days of economic growth and full employment in Malta seemed like a distant memory to him. The 22year-old newlywed electrician lived at his family home in Cospicua, beside Malta's Grand Harbour. Sounds of work no longer echoed up the familiar, narrow roadways leading into town from the waterside. Concerned for his own job security, Muliett increasingly thought of leaving his homeland for the United States. Many of his mates considered a similar path, as stories of automobile factories in Detroit hiring thousands of workers at good wages sounded better than waiting for the British Admiralty to decide on what to do with the work force at the Royal Navy Dockyard. For Muliett, job insecurity brought especially intense pressure, as he and his wife Francesca were expecting a child.

In April 1920, Muliett was an ocean away from Cospicua, landing in New York City. ${ }^{36} \mathrm{~A}$ short time later Muliett found work as an electrician for Chrysler Motor Company in Detroit, thanks in large part to the skills he learned working at the Royal Naval Dockyards. ${ }^{37}$ Like a large portion of his fellow Maltese laboring at the city's auto plants, Emmanuel spoke and wrote English and was accustomed to operating in the Anglicized world. This critical advantage gave Maltese men a key leg up in translating their skills to their new world. Even if they only could speak a small amount of English well, those skilled workers let go from the British Royal

\footnotetext{
${ }^{36}$ Passenger Lists of Vessels Arriving at New York, New York, 1820-1897. Microfilm Publication M237, 675 rolls. NAI: 6256867. Records of the U.S. Customs Service, Record Group 36. National Archives at Washington, D.C.

${ }^{37}$ Rose Mifsud, interview by author, Farmington, MI, November 19, 2012. Mrs. Mifsud is the daughter of Emmanuel Muliett.
} 
Dockyards would have spent a chunk of time in their career working in an Anglo-world.

Nevertheless, Detroit's Maltese community was for a time a mostly male world; Muliett's wife Francesca and newborn Lawrence did not join him in his trek across the Atlantic. Due to the newly passed Quota laws, their separation became extended. In the end, he was one of the lucky ones, Francesca and Lawrence were allowed to emigrate in 1925, the first year of an increased Maltese quota. ${ }^{38}$

Despite the success of the first wave of Maltese migrants, the problem the Mulietts and others faced in reuniting with their families were largely political. The passage of the Immigration Act of 1921 initially cut off any immigration from Malta, even for dependents like wives and children. Because their migration to the United States did not begin in earnest until 1919, and the Act used the 1910 census as a basis for the quota, Malta was subject to a dismal quota relegation with "Other Europe.” This meant countries and territories like Gibraltar, Andorra, San Marino, Lichtenstein, and initially Iceland all shared just 86 quota slots per annum. The result was devastating. The vast majority of those who had come to the US just before the quota were single men, like Emmanuel Muliett, leaving behind families to establish a new life in the States before sending for wives and children. Expecting to soon join their husbands, fiancés, and fathers, those who remained in Malta had sold their possessions preparing for their journey westward. Henry Casolani, Director of Emigration in Malta, wrote in the 1922 Report on Emigration that "to the uninitiated, this [Immigration Act of 1921] is a mere definition; to the

${ }^{38}$ Francesca and "Lorenzo," later anglicized to Lawrence, arrived in New York City on 28 April 1925 aboard the S.S. Majestic. Unlike her husband who spoke and wrote in English, Francesca, who was Italian and not Maltese, is recorded at the time to have only spoken Italian and no English. Passenger Lists of Vessels Arriving at New York, New York, 1820-1897. 
intending Maltese emigrant to the United States of America it means a great disappointment...it spells disaster." 39

Just as the Maltese government worked with London to pressure Ottawa on immigration issues, Washington felt similar heat in the aftermath of the law. Immediately the Maltese government took to protesting the unfair treatment, and their protests grew louder when Iceland was granted a separate, unshared quota. What made the shared quota of 86 especially harsh was how loosely regulated it was. The government of Malta endeavored to keep its emigration to just a mere fourteen individuals a year, a sixth of the quota share even though they believed that Malta alone should be awarded at the minimum 50 of the 86 slots. The reason Malta kept emigration so low was a fear of rejection and thus repatriation of the rejected migrant.

Essentially, each year was a race to get to America before the quota was filled. One never knew who else was making the crossing to America, and when the quota would be filled. Competing with five other nations made it all the more frantic. In addition, a migrant born in any of the "Other Europes" who entered the United States from a territory like Canada or the United Kingdom still counted for the quota of the "Other Europes." 40 The scramble for America was real, and for those making the crossing, it was also terrifying as uncertainty dominated their world.

The major difference between US restriction and Canadian restriction remained Malta's place within the Empire. Unlike the political to-and-fro occurring simultaneously with Ottawa, which flat out refused the Maltese, immigration law in the United States seemingly meant little

\footnotetext{
${ }^{39}$ Henry Casolani, Report on Emigration, For the Fiscal Year 1922-1923. Malta: Government Emigration Office, 11 October 1923, Document attached to Consul Mason Mitchell to Malta to the Department of State, 27 October 1923, 849B.56/14, RG 59, Records of the Department of State, NARA II, College Park, MD, 11.

40 These five nations, Malta, Gibraltar, Andorra, San Marino, Lichtenstein, were categorized under the law as "Other Europes."
} 
harm to Malta. Even the Maltese government felt that the new quotas were not deliberately put into place by the American government to halt Maltese migrants. For Maltese to be kept out of Canada, a fellow imperial nation, was a challenge to their Britishness. To be kept out of the United States was an unfortunate overlooking of Malta's position and needs. The closure of America was even more harsh for the Maltese considering their migrants had been "regarded as an asset in the great American Republic." ${ }^{\prime 41}$ Therefore, despite the severity of the situation thousands of men left without their families - the response from Valletta was constant pressure on American diplomats, but in a much milder tone. In a 1922 Emigration Report submitted to the American Consulate in Malta, Henry Casolini wrote that "the fact remains however that, incidentally, there is no country in the world which the American Bill has, unconsciously, though effectively, hit so severely, in its practical application than the Islands of Malta and Gozo." ${ }^{42}$

While politicians and political actors worked overhead, the Maltese men on the ground in the United States had difficult decisions to make in 1921. Those who left their families behind had to choose to stay in the States and hope their family would soon rejoin them, or return back to Malta. Hundreds of men did the latter, returning home and unfortunately swelling the ranks of the unemployed there instead of staying abroad and earning money. Understandably, the pull of family was strong enough for many to be the deciding factor. Those who chose to stay, particularly those in Detroit, were often the most skilled laborers. These individuals generally secured good jobs quickly, spoke some English, and made the transition to their new lives fairly seamlessly. In addition to securing work, those who stayed in the United States wrestled with the benefits of becoming nationalized as quickly as possible. The process of naturalization and eventual citizenship offered one way in which Maltese men could send for their families. But,

\footnotetext{
${ }^{41}$ Henry Casolani, Report on Emigration, For the Fiscal Year 1922-1923, 11-12.

${ }^{42}$ Henry Casolani, Report on Emigration, For the Fiscal Year 1922-1923, 12.
} 
even those who gained citizenship would have a long process filled with legal work to secure passage for their family members, perhaps taking years as well.

Those who stayed, or those who looked to enter, often found creative ways of pushing the quota limits. For some barred entrance into America, it meant a turn to illegal immigration. Many who could not enter the United States tried their luck immigrating to Canada and then under the cover of night crossed the Detroit River to join their compatriots. This was a limited number of individuals, given how difficult it was to migrate to Canada, but the stories of illegal immigration to Detroit via this route persisted in the community. ${ }^{43}$ Sometimes the international border between Detroit and Windsor created a need for illegal immigration. One story mentioned a father who found employment in Windsor but was unable to secure a visa to the United States. Somehow, the rest of his family did, and so the family was divided with the father living in Windsor and his family across the river in Detroit. To see his family, he would sneak across the border at night and stay with them during weekends. On the rare occasion that immigration officers came by, the family would hide him in the coal cellar until the officers had left. This routine continued for several years while he awaited his papers to enter the United States legally. ${ }^{44}$ As the story of Vincent Vassallo at the beginning of this chapter highlighted, the drive to come to the United States was intense, even for those settled in Canada.

Beyond politicians and illegal crossings, the Catholic Church played a significant role in efforts to get the Maltese to the United States. The growing community in Detroit pressured the Church hierarchy, including direct appeals from the Maltese priest in Detroit, Father Michael

${ }^{43}$ Joseph M. Lubig, Maltese in Michigan (East Lansing: Michigan State University Press, 2011), 15.

${ }^{44}$ This information comes from an interview conducted in 2014. The individual discussing her father's migration did not want to be named or have her father be named, despite the fact that he has passed away. 
Borg. His letters to the Bishop of Detroit were used to put pressure on the American quota. ${ }^{45}$ These complaints and the desire to see the quota lifted appeared publicly through the work of the Bishop of Puerto Rico, George Caruana, who was of Maltese descent. He argued that the Maltese should have been allowed to enter the United States by sharing the excess population from the British quota. ${ }^{46}$ Bishop Caruana fought against the quota system at the American Bishops' Conference in 1923 and eventually helped to inspire a changed term of entry for the Maltese through negotiations at the Conference. ${ }^{47}$ These actions helped cement the Catholic Church's role in the new Maltese community of Detroit, but they represented just one avenue of social change.

Political pressure which aimed to increase the Maltese quota joined ongoing social efforts and those combined forces began to pay dividends. The efforts of the Maltese government, who claimed to work harder than any other Southern European government to get the quota raised, enjoyed some success. Meanwhile, Malta was able to leverage British support to influence American legal structures. Under the reworked Immigration Act of 1924, Malta was granted use of the British Quota under the supervision of London. Initially Britain granted just ten spots, but protests forced Britain to increase the number to sixty slots, which were established specifically for the Maltese. Anything over that would have to be negotiated within the Imperial structure. For 1924 and 1925 those imperial negotiations yielded thirty-six extra slots granted by the Consulate General from the British overall quota, giving Malta ninety-six immigrant slots. ${ }^{48}$

\footnotetext{
${ }^{45}$ Michael Borg, "Letter Against Immigration Law from Fr. Borg," October 11, 1922, St. Paul Parish Collection, 1-3 Correspondence n.d., 1921-1937, Archdiocese of Detroit Archives.

${ }^{46}$ Lubig, Maltese in Michigan, 37.

${ }^{47}$ Ibid.

${ }^{48}$ Philip Adams, "Transmitting Copies of Official Report on Emigration from Malta," Malta to the State Department, November 3, 1925, 849b.56/15 RG 59, Records of the Department of State, NARA II, College Park, MD, 2-3. Malta pressed hard and in every way, for an increase of her Quota: - Pleadings, Conferences with the American Consular Authorities, Telegrams, Memoranda, private communications from Ministers to American State Secretaries and personal representations in London by the Superintendent of Emigration with the powerful
} 
Continual pressure from politicians and social figures alike, coupled with the transition from being treated as an independent territory to one within the British realm continued to improve Malta's quota situation.

The increase to ninety-six slots within the quota should have been welcome news in Malta, yet many still felt poorly-treated by the government of the United States. Much of this public perception was actually a reflection of Malta's own Emigration Department. Attempting to deal with the massive backlog of spouses and children separated from their beloveds, the Emigration Department restricted the amount of quota available to new intending migrants. This restriction in 1925 meant only ten new, unemployed and intending emigrants, were given visas for the United States. The other eighty-six slots addressed what was seen as the great humanitarian crisis of the islands, the separation of families. By 1926, the Emigration Department had to abide by a new wrinkle. Additional American legislation stated that up to $50 \%$ of the quota must be reserved for "preferred" emigrations - wives, children, and parents of American citizens. Because so many Maltese men in the United States rushed to get their citizenship to secure their families' transit, that 50\% quota was "entirely bespoke," including "at least the two succeeding Quotas." ${ }^{, 49}$ To the Maltese public who did not understand the intricacies of the American Immigration law, it seemed as though the quota had hardly budged. As the quota opened further, the Emigrant Department attempted to placate the pent-up demand for new migration to the United States, balancing new migrants against family reunions.

assistance of the Foreign Office, and innumerable despatches to the Imperial Authorities. No stone was left unturned and no opportunity was lost to further the case of Malta.

${ }^{49}$ Henry Casolani, Report on Emigration and Unemployment, 1926. Malta: Government Emigration Office, 9 September 1926, Document attached to Consul Sidney E. O’Donoghue to Malta to the Department of State, 12 October 1926, 849B.56/18, RG 59, Records of the Department of State, NARA II, College Park, MD, 27. 
By 1926, Maltese officials seemingly had pushed as far as they could politically, both domestically and internationally. Although few letters, memos, or other official documents surfaced through the sands of time to explore what exactly was stated and to whom, the Maltese Reports on Emigration on the international situation in 1926 claimed, "Indeed, our demands became so constant and so insistent as to elicit, on one occasion, an expression from the Imperial Authorities that it would be undesirable to press the American Government any longer as the limit of concession had been reached." ${ }^{50}$ Despite warnings that the Americans had been pressed to the limit, the quota gradually opened even further for the Maltese. Already in 1926, it had doubled to 200 per annum. As the quota gradually opened, the selective system used by the Maltese Emigration Department, regulating who could and could not emigrate from Malta, came under intense scrutiny domestically.

The largest number of complaints against the Selective System revolved around the 13,000 individuals refused approval to migrate. A confidential memo back to Washington from the American consular official in Malta, Sidney O'Donoghue, quoted the Mercurius, a daily newspaper in Malta on the issue. The local Chamber of Commerce wrote to the paper on October 12,1926 that,

Out of probably 40,000 applications for permission to emigrate since 1918, only 27,000 were passed. In view of the present deplorable economic situation we cannot but wish that 40,000 persons had emigrated... That the selective system has saved considerable suffering to certain classes of emigrants we do not doubt, but we challenge the right of the Government to ascertain whether a man has sufficient capital or experience to migrate to any specified country. Persons who make up their mind to emigrate know full well that they are taking a great risk. Why,

${ }^{50}$ Casolani, Report on Emigration and Unemployment, 1926, 26. The report notes that the Government of Malta was pushing the American government on several fronts, through the Consular Official, through memos, memorandums, appeals to the Secretary of State, and constant visits to London for consul with Leo Amery, the Secretary of State for the Colonies and, as Henry Casolani called him, the man who knew the most about immigration internationally. 
therefore, should the State seek to restrain men from emigrating when they are prepared to take the risks. ${ }^{51}$

While O’Donoghue agreed, in principle, with the editorial, stating that there were several individuals who were denied emigration despite their "fair education and breeding," he did hold the "one man show" in high regard. Though there existed opportunity for corruption in the department, as it was run almost entirely by Superintendent Henry Casolani, O'Donoghue called Casolani a "man of good education, wide reading, high ideals, and with an immense interest in his work." But even this was followed with a disclaimer that some of Casolani's decisions were quite arbitrary. ${ }^{52}$

Despite the negative press, the Selective System provided an excellent service and crafted a migrant well-prepared for success overseas. Casolani wrote several defenses of the system, claiming chief among them that the selection had saved Malta "costly repatriations at Government expense, and financial assistance to distressed Maltese abroad." ${ }^{, 53}$ For a government struggling to balance domestic and international needs on a small yearly budget, this was immensely positive. Beyond the finances, Casolani pointed to several reports that suggested that Maltese did well overseas and linked their success to his restriction of emigration to only the most well-prepared migrant. In his 1926 Report on Emigration, he quoted the Right Reverend Msgr. Paul Gauci who travelled to the United States and reported back on the Maltese condition. Msgr. Gauci claimed that Maltese "are all well, from every point of view, moral, social, economic, and religious. They are well disciplined, they attend work honestly, are sober, and the least who give trouble to the police...I am told that their employers are not only fully satisfied

\footnotetext{
${ }^{51}$ Sidney E. O’Donoghue, “Transmission of the Report on Emigration and Unemployment for 1926," 2.

${ }^{52}$ Ibid., 3.

${ }^{53}$ Casolani, Report on Emigration and Unemployment, 1926, 3.
} 
with their behavior, publicly and privately, but they also give preference to the Maltese in every kind of work, as far as they can do it." ${ }^{, 54}$

Prospects for Maltese emigration to the United States continued to improve, despite official political pessimism. A letter back to Washington in 1927 from Sidney O’Donoghue, suggested that despite Maltese officials pushing for a higher quota, no push would likely come to Washington directly from the British Colonial Office. ${ }^{55}$ And yet, each year the quota continued to grow. By July 1, 1929 the quota grew to 380. It was further bumped up twice over the course of the next year, once by 76 visas and finally an increase of 84 visas. By 1930, at the onset of the Great Depression, the Maltese quota had reached a peak of 540 per annum which proved more than sufficient given the global economic downturn. For the first time, Malta could not fill all of the allotted slots, sending only 505 emigrants that year. Finally, it seemed, Malta had broken through and re-achieved - for their needs at the time - a virtual open door to the United States, pried open through Imperial muscle. ${ }^{56}$

What occurred in the 1920s across North America exhibited how fluid identity could be, and furthermore, how that identity - recognized universally - could result in such different migration outcomes. The Maltese were Britishers in the 1920s. In Canada, however, they proved to be the wrong "kind" of Britisher. Despite protestation, they were never able to convince

\footnotetext{
54 Ibid.

${ }^{55}$ It is important to note that throughout this time, Maltese come to the United States both from Malta and from other nations, often Canada and the United Kingdom. One case, Joseph and Carmela Cachia, had been living in Canada when they received their letters stating their names had been reached on the British quota. They received their letter on April 2, 1930 and had to report to the American consulate in Toronto, where they lived, within a week for processing. "Immigration Requests," American Consulate, Toronto, April 2, 1930, MU 9783, F1405-89-6, SR 5108, Ontario Proviwncial Archives, Toronto, Ontario; Sidney E. O’Donoghue, “Transmission of Five Copies of Malta Emigration Report” Malta to the Department of State, December 10, 1927, 849B.56/20, RG 59, Records of the Department of State, NARA II, College Park, MD, 1.

${ }^{56}$ Hugh Arrigo, Annual Report of the Emigration Department 1929-1930, Malta Government Emigration Office, September 20, 1930, Document attached to Consul Hugh S. Miller to Malta to the Department of State, 849B.56/25, RG 59, Records of the Department of State, NARA II, College Park, MD, 20. Although the Maltese quota remained capped at 540, there were no longer enough Maltese willing to migrate to the United States that it demanded further raises. The Maltese would not come close to topping this quota number until after World War II.
} 
Canadian authorities that they deserved to be treated as equals within the same imperial structure. Yet, in the United States, empowered by imperial power structures, the Maltese were able to gradually increase their position within the quota system through imperial might and the recognition of their race as British Europeans. By 1930, when the United States had set the quota at over 500 Maltese, Canada - still bound only by definition and not technically a quota restricted Maltese movement to less than fifty. Much of this was attributed to the type of Maltese migrant that already made their homes in the United States. This was especially the case for those who made their homes in Detroit. Coming with industrial trade skills, many of the first migrants secured steady, good paying jobs, and began the integration process rather quickly. This stable community not only acted as an anchor for future migration, but also as an example to American authorities and the press of the excellent quality among Maltese.

\section{Social Development in Detroit}

Achieving economic stability and striking a balance between American and immigrant culture represented the ultimate success story for any immigrant in the $20^{\text {th }}$ century. Settled into two areas of Detroit, the newer immigrants in Corktown to the west of the city center, and the more seasoned migrants making their homes in Highland Park, an independent city within Detroit, the Maltese had several tools to achieve the aim of integration or cohabitation. In the United States, in contrast to the experience in Canada, Britishness became a tool on the pathway to integration. Through the use of skills learned during a century of British rule, including the overwhelmingly large number of emigrants who had experience in British industry, the Maltese leveraged that to their advantage. At the same time, Maltese immigrants settled in through a strong association with the Catholic Church. The use of religion gave the early community a 
level of comfort, one that helped them blend in with the large Catholic immigrant working class in the city. Consequently, the integration story of the Maltese was one that heavily emphasized class. Their industrial skills and British background made them welcome as workers and their Catholicism enabled them to integrate easily into Detroit's working-class culture. Comfortable with those, many Maltese adopted aspects of a more American life style, picking up a love for Detroit Tigers baseball and building lake homes "up north."

Certainly, the Maltese story runs counter to the immigration narrative from Southern Europe which experienced severe restrictions in 1921 and 1924. While they did not represent massive numbers, the largest percentage of Maltese who left their homeland for the United States in the $20^{\text {th }}$ century did so after 1921 . Skilled Maltese laborers coming to North America from 1919 to 1924 established a secure anchor for the later generations who arrived after the restrictions were eased ${ }^{57}$ Emmanuel Muliett and his fellow Maltese came from an imperial setting, and Malta's inclusion in the British Empire reinforced the ability of its people to live in multiple worlds. Anglo-centric institutions of local government, legal systems, and industrial employment had operated on the island since the nineteenth century. English and Maltese were the primary languages taught in schools.$^{58}$ To operate within the British Empire, locals had to accept a level of familiarity with the greater Anglo world. Nevertheless, the other world-their Maltese world-operated quite differently. The island's population was staunchly Catholic, and the public generally refused any official effort to promote the Church of England. In addition, the Maltese language, Semitic-based, remained popular among natives. Living in two worlds had

\footnotetext{
${ }^{57}$ Many of those who migrate to the United States after the Immigration Act of 1924 enter the country under a British sub quota assigned to British colonies. Consular documents showing exchanges between the United States, Britain, and Malta in the late 1920s show that the British government had final say on how to allot their given quota and the pressure to increase the quota for Maltese would fall on London and not Washington.

58 John Chircop, ed, Colonial Encounters: Maltese Experiences of British Rule, 1800-1970s, (Hal Qormi, Malta: Horizons Publishing, 2015), 17.
} 
thus become second nature to many, especially those employed in British defense establishments.

By 1920, The Maltese in Detroit had exhibited that exact ability to transition seamlessly into the Anglo-world. The Detroit Free Press ran an article titled "Detroit's Maltese Colony is Largest in America" in which the author described the Maltese people. The article pointed out the amount of similarity between the Maltese and the average American, showing how well these new migrants had quickly assimilated to American culture. It stated,

They have adopted our dress and (habits) about the streets, so that except for the strange tongue, half Arabic, half Italian, which they speak they are hardly distinguishable from Americans...In complexion they vary almost as much as we do from fair skin and blue eyes to olive skin and very dark eyes. On the whole they look rather like Americans. Their children especially are like American children in looks and manners. ${ }^{59}$

The Maltese migrants to Detroit used their comfort level to establish their community and to secure a path towards successful cohabitation. Their workplace advantages certainly helped further this cause, as did a small number of Maltese who had landed in Detroit prior to the First World War and helped to house new migrants in 1919 and 1920. Upon coming to the city, many Maltese found lodging with established Maltese. Others found themselves living with either native-born Americans or Anglo-British Subjects.

The longstanding imperial connection the Maltese held so dearly opened doors for migrants in Detroit. As the city changed physically with its tremendous growth, the ability of immigrants to experience social mobility solidified in neighborhoods. The segregation of neighborhoods by ethnicity in the 1920 s mimicked the industrial opportunities available. ${ }^{60}$ The

\footnotetext{
${ }^{59}$ Bernice Stewart, "Detroit's Maltese Colony is Largest in America," Detroit Free Press, December 12, 1920.

${ }^{60}$ Oliver Zunz, The Changing Face of Inequality: Urbanization, Industrial Development, and Immigrants in Detroit, 1880-1920 (Chicago: University of Chicago Press, 1982),
} 
familiarity with the Anglo world helped the Maltese gain access to places to rent in neighborhoods that aided in their integration process. A large portion of Maltese living in Detroit in the 1920s started their stay with other Anglo-families, if not with Maltese families themselves. Individuals like the Fenech brothers rented a home on Fourth Street in Corktown, splitting that home with three Canadians, and living next door to English families on both sides. ${ }^{61}$ These types of living arrangements gave the Maltese yet another advantage over other ethnic communities forming in Detroit at the same time. Settling in Anglo neighborhoods was an advantage in social advancement for the Maltese.

Perhaps the most important institution established by Maltese migrants in Detroit was a Maltese parish in the Catholic Church. The church acted as a spiritual, moral, and at times physical guide to the new migrants. Before emigrating to Detroit, the Church in Malta played a key role in preparing the emigrants for their departure. The Church gave advice at the docks to people preparing to depart with priests telling the groups to fit in by "quickly adopting the local customs, keep good hygiene, work hard, don’t gamble and be good." ${ }^{62}$ Lorenzo Manché, a local professor and advocate of emigration in Malta, told those leaving that "Man did not live by bread alone; he had a soul to look after." He reminded them: "Do not forget that you are Maltese and that your ancestors have lived as Christians since the arrival of St. Paul. Therefore, wherever you are, do not ignore your religious duties." ${ }^{93}$ The Church's influenced was even suggested, and thought to be used in 1919, to convince people that it was necessary for individuals to leave Malta for the greater good of the island. ${ }^{64}$ This push by the Catholic authorities in Malta

\footnotetext{
${ }^{61}$ National Archives and Records Administration, Year 1920; Census Place: Detroit Ward 4, Wayne, Michigan; Roll: T625_805; Page 14A; Enumeration District: 125; Image: 487.

${ }^{62}$ Attard, Profiles in Maltese Migration, 42.

${ }^{63}$ Ibid.

64 Ibid., 38.
} 
suggested that the Church's power was quite legitimate in the eyes of the individuals emigrating abroad.

The Catholic Church did not just dispense advice to parting migrants, but became part and parcel of their new experience in Detroit from the very beginning. The Church that the Maltese encountered in the United States, however, was structurally very different from the one they had left in Malta. American Catholicism was hardly unified, largely due to the strong ethnic nature of the Church in America. One of the only unifiers in the American Catholic community was the opposition it faced from Protestant Americans. ${ }^{65}$ Even though Catholicism was not a new religion to the United States, as nearly forty percent of church-going Americans were Catholic by 1870 , new waves of ethnic communities continually added their own unique regional twist to Catholicism which further divided the Catholic Church in America. ${ }^{66}$ One key difference between the Church in Malta and the Church in America was the character of the local parishes. While in Malta parishes were based on local geography - a town, village or neighborhood - in the United States they were often based on ethnicities like Italian, German or even FrenchCanadian. These ethnic groups often clashed over who could preach to them, preferring a native from their own lands. ${ }^{67}$ This operated as a benefit for immigrant communities in the United States however as it gave the ethnic community an avenue for addressing concerns within the regional or even national political structures.

Once the Maltese had made their home in Detroit, establishing their church community was accomplished quickly. Louis L. Goodnow of the Detroit News wrote in 1922 that four thousand Maltese gathered to worship at Most Holy Trinity Church in Corktown, where special

${ }^{65}$ Chudacoff and Smith, The Evolution of American Urban Society, 122.

66 Ibid.

${ }^{67}$ Leslie Woodcock Tentler, Seasons of Grace: A History of the Catholic Archdiocese of Detroit (Detroit: Wayne State University Press, 1990). 
services were held for them until they had their own priest. Goodnow noted that the Maltese appeared to be among the most devout Christians in the world. ${ }^{68}$ Their appetite for a priest of their own was fulfilled by Bishop Caruana who visited the community to satisfy some of its earliest religious needs. During his visit to the community in 1919 he celebrated a Maltese mass at Most Holy Trinity. ${ }^{69}$ Quickly, Bishop Gallagher of Detroit decided it was time to appoint a priest for the Maltese community and sent word to Malta to send a priest to Detroit. The man sent in late 1920 was Father Michael Borg, a native of Malta and a former chaplain to Australian forces in World War I, who entertained the thought of moving to Australia. Instead, he accepted the call to Detroit "because that was the place where everybody seemed to be going." 70 Borg was appointed priest of St. Paul's Maltese Church, established in 1920 by Bishop Gallagher, and celebrated its first mass on November 14, 1920 in a church located at the former Knights of Equity Hall on Second Avenue and Fort Street. ${ }^{71}$

The Maltese love affair with the Church was clearly evident. They were devoted in their celebration of the Christian calendar, celebrating Saints' Feast Days, called Festas, which provided opportunity to retain a distinctly Maltese identity. ${ }^{72}$ Although the Maltese community established a social club early on, it was not the ideal place to share their cultural heritage. The club carried the stigma of being a dirty place where politics, both American and Maltese, were discussed and it was not deemed fit for women and children. The Church on the other hand was a better center for the community as a whole when it came to finding a gathering place. ${ }^{73}$ The

\footnotetext{
${ }^{68}$ Attard, Profiles in Maltese Migration, 108.

69 “'Only Maltese 'Colony' Here: Mediterranean Islands form Church, Retain Ideals and Spirit," The Detroit Free Press, December 12, 1922.

${ }^{70}$ Attard, Profiles in Maltese Migration, 106.

${ }^{71}$ St. Paul Parish Collection, 1-6 History, n.d. 1921-1969, Archdiocese of Detroit Archive.

72 David Boswell, "What's in a Name? The Social Prestige of Residential Areas in Malta as Perceived by Their Inhabitants," in The Urban Context: Ethnicity, Social Networks and Situational Analysis, eds. Alisdair Rogers and Steven Vortovec (Oxford: Berg Publishers), 288.

73 Attard, Profiles in Maltese Migration, 109.
} 
Malta Daily Chronicle, a daily newspaper in Malta, claimed that the success of the colony in Detroit was due to its establishment of a church, a common spirit of nationality, and a Maltese language newspaper. ${ }^{74} \mathrm{By}$ the end of 1922, seventy-four Maltese baptisms, seven weddings and twenty-one funerals had taken place at St. Paul's. ${ }^{75}$ Praise continued to come to the community, as Bishop Caruana complimented the parish on its devotion. He then used the pulpit to encourage assimilation and urged parishioners to get involved in American social life and politics. At the same time, he cautioned them to retain a balance between their new American life and the culture they brought with them so "that America may be endowed with the culture of a historic people who were for centuries the vanguard of Christianity against the Moslems." ${ }^{76}$

Stopping in Detroit on an American tour in 1920, the Bishop of Malta, Michael Gonzi, drew massive crowds. Headed to Chicago for the International Gathering of Catholic Prelates, over three thousand Maltese were reported to have met him at Michigan Central Station when he stopped in Detroit. ${ }^{77}$ Large masses were commonplace in the earliest years of the community as more than four thousand attended a mass by Bishop Caruana in 1921 during one of his stops in Detroit. ${ }^{78}$ Lenten services in 1921 were often so large that Father Borg invited both Bishop Caruana and Reverend James Baldacchino, another Maltese priest in the United States, to come to Detroit to help preside over services. ${ }^{79}$ Such displays of piety enabled the Maltese to claim their place in a Catholic culture that relished large public events. Both the St. Vincent de Paul and the Holy Name Society, for example, held large events, including a mass at Navin Field,

\footnotetext{
74 “Only Maltese ‘Colony’ Here,” The Detroit Free Press, December 12, 1922.

${ }^{75}$ Attard, Profiles in Maltese Migration, 111.

76 “Only Maltese ‘Colony' Here,” The Detroit Free Press, December 12, 1922.

${ }^{77}$ Attard, Profiles in Maltese Migration, 113.

${ }^{78}$ Ibid., 88.

${ }^{79}$ Lubig, Maltese in Michigan, 32.
} 
which hosted a reported 90,000 people worshiping at the ballpark in Corktown. ${ }^{80}$ For the Maltese, this Catholic community in their newly acquired home must have delivered a sense of normalcy, with large festive events to which many immigrants from Malta were accustomed. Still, there were adjustments to be made. One early member of the community, Paul Portelli, wrote home to his uncle in 1921 expressing disappointment that the community as a whole missed not having the large carnival celebrations like those they were accustomed to in Malta. He later wrote, "These are the days when we wish to be back in Malta because there is nothing like that over here. We celebrate Carnival with friends in the place where I live." ${ }^{81}$ While the Catholic community as a whole enjoyed large celebrations, specific ethnic festivals rarely transcended ethnic lines. To bridge that gap and connect with other Detroiters through the Church, the Maltese established religious clubs. Trinity Club, founded in 1922, was a Catholic group organized by Maltese women to sponsor social functions in hopes of connecting the Maltese of Detroit with their fellow Catholics around the city. The group met in the Knights of Equity Hall, the original home of St. Paul's Maltese Church, and held even non-religious functions like traditional American festivities mixed with Maltese traditions to aid in assimilating to the local culture. ${ }^{82}$ This was a very important role for women to take in the Maltese community. The founding of the Trinity Club gave Maltese women an outlet to positively affect the lives and community they were creating in Detroit.

Despite the massive numbers of Maltese who supported the Church, divisions existed at the ground level over how the Maltese parish should be structured. These divisions sprang from

${ }^{80}$ Tentler, Seasons of Grace, 428. If a mass of 90,000 was truly said at Navin Field, and Maltese attended, this would have been far larger than any event they would have ever witnessed in Malta. Malta's population in the 1920 s was just over 200,000.

${ }^{81}$ Attard, Profiles in Maltese Migration, 110.

${ }^{82}$ Lubig, Maltese in Michigan, 36. 
two sources; one grew out of political differences between Reformists and Anti-Reformist Maltese, carried over with them from Malta. The reformists, influenced by Italian culture, sought complete independence from Great Britain, while their counter-parts looked towards a continuation of Imperial rule and British culture. ${ }^{83}$ The second factor was a disagreement over the physical parish to which many Maltese went for Sunday mass. Despite the community in Detroit living in relative proximity in the Corktown neighborhoods, there were two different churches that commanded their loyalty. For those Maltese who lived north of Michigan Avenue towards Plum and Fourth Streets, St. Paul's Maltese parish was the closest church. But for those on the south side of Michigan Avenue, Most Holy Trinity Church was the closest comfortable walk from many of their homes. These divides, while not damaging to the community as a whole, certainly existed and separated Maltese families in the city for all but major social events. The appointment of Father Borg was not without detractors. Complaints against his leadership of the community were almost instantaneous. Letters deriding the priest poured into the Bishop's office during 1921, less than a year after his appointment. Some claimed that the lax Fr. Borg refused to baptize their children; others like Joseph Zammit and Lawrence Vassallo resigned from their posts on the Church Committee in protest, citing Fr. Borg's "inefficiency" and "purchasing of unnecessary articles with Church funds, without consulting the Church Committee. ${ }^{, 84}$ Further accusations included refusing to hear confessions from men who

${ }^{83}$ The divide in the community was a long brewing argument over the purchasing of the Plum Street Church in 1924. The divide between Reformist and Anti-Reformist Maltese erupted. This rift in the community was noticed as early as 1922 when the editor of a newly published newsletter L-Ecu Malti fl'America [The Maltese Echo in America] proclaimed that his publication would "help in the search for a solution to the rift which was tearing apart the Maltese community in Detroit" and to "defend the Catholic heritage of the Maltese living in Detroit." Newspapers connected to politicians in Malta and the Maltese Association of Detroit printed short publications expressing their opinions on the purchase. Divide, however, was nothing new with the Maltese either at home or abroad as the rift between Reform and Anti-Reform communities was preceded by a long tradition of spilt between urban communities as well as the urban population as a whole and rural communities in Malta.

${ }^{84}$ Joseph Attard, "Letter against Fr. Borg," Personal Letter, (October 12, 1921), St. Paul Parish Collection, 1-3 Correspondence n.d., 1921-1937, Archdiocese of Detroit Archives. 
desperately sought them. It was noted that he "stated that the Holy Mother of God was not a Virgin, that the Church made Her a Virgin. ${ }^{" 85}$ In yet another letter, Fr. Borg is reported to have "admitted himself that he is not a good preacher." 86

In hopes of finding community stability, the Maltese turned to secular organizations to advance their cause. The "Maltese American Welfare Association," established in 1921, undertook the task of both religious and secular welfare for the community. ${ }^{87}$ The Association showed a community that was connected with other Maltese across the nation, writing in one of its letters to the Bishop that it had undertaken the task for the Diocese of finding alternative priests to serve the community in Detroit. Another Maltese priest, Father Aurelio Ciantar, already resided in Detroit and a third, Fr. Gelasio Bugeia was at the time in Philadelphia. The community offered both of these men as options to replace Fr. Borg in a 1922 petition. ${ }^{88}$ However, Bishop Gallagher refused to move on the replacement of Fr. Borg, preferring to coax Fr. Borg into action through official church channels.

Certainly, Bishop Gallagher had his reasons for keeping Fr. Borg on as the head of St. Paul's Maltese. With the passage of the 1921 Immigration Act, it was Fr. Borg who championed the cause of the Maltese in political circles. In 1922, the priest wrote a letter praising the Maltese and their assimilation efforts. But his main aim was to tackle the major injustice the Maltese community faced. The Immigration Act, as previously described, stuck Malta with a rigid quota, which kept families in permanent separation. Borg's letters to politicians and to the Bishop

\footnotetext{
85 Ibid.

${ }^{86}$ Joseph Zammit, “Letter from Joseph Zammit against Fr. Borg,” Personal Letter, (October 17, 1921), St. Paul Parish Collection, 1-3 Correspondence n.d., 1921-1937, Archdiocese of Detroit Archives.

${ }^{87}$ Joseph Attard, "Founding of Maltese American Welfare Society," Community Letter, (December 22, 1921), St. Paul Parish Collection, 1-3 Correspondence n.d., 1921-1937, Archdiocese of Detroit Archives.

88 "Petition to Remove Fr. Borg," 1922, St. Paul Parish Collection, 1-3 Correspondence n.d., 1921-1937, Archdiocese of Detroit Archives. The petition to remove Fr. Borg was followed by 10 pages of signed names, totally 253 names, asking for his removal.
} 
aimed to change the quota restriction, proposing that wives and children of migrants already settled in Detroit be allowed entrance into the United States instead of an increased quota for the islands ${ }^{89}$ Fr. Borg's work did not go unnoticed or unappreciated. A year later in a promotion for a new Maltese newspaper in the city, Frank Borg - unrelated - argued that the other Maltese newspaper in the community attempted to discredit Fr. Borg simply to tap into a sentiment that it believed would sell papers. ${ }^{90}$

Despite the insistence of Frank Borg and his new newspaper and the efforts put forth by Fr. Borg to aid in emigration, the role of the embattled priest began to decline in the community and within the Diocese. By 1924, the Maltese community had outgrown the old St. Paul's Parish at the Knights of Equity Hall and required a new, larger building to house their parish. A new home, the former Plum Street Church of Christ, was acquired on Fourth and Plum Street just two blocks north of the Equity Hall. ${ }^{91}$ The acquisition of the new building was necessary for the growing parish, but doomed Fr. Borg who mishandled the finances so badly that by 1926 a lien was placed against the mortgage by builders for $\$ 426.00$. The need to watch Fr. Borg so tightly became a wearisome and very annoying task that the Diocese did not want to deal with. ${ }^{92}$ The Diocese began in 1926 to search for a new Maltese pastor to fill the role.

The Detroit Diocese looked to New York City and brought in Father Michael Cefai to fill the role of Maltese pastor. Coming on only a trial basis, Fr. Cefai soon wrote back to Bishop Gallagher lamenting that the was only able to visit for such short time spans. The great spiritual need of the community was clearly evident to him, writing "The situation of the Maltese Parish

\footnotetext{
${ }^{89}$ Michael Borg, "Letter Against Immigration Law from Fr. Borg,” October 11, 1922, St. Paul Parish Collection, 1-3 Correspondence n.d., 1921-1937, Archdiocese of Detroit Archives.

${ }^{90}$ Frank Borg, "Letter to Bishop on the Malta Press USA," Community Letter, December 5, 1923, St. Paul Parish Collection, 1-3 Correspondence n.d., 1921-1937, Archdiocese of Detroit Archives.

${ }^{91}$ St. Paul Parish Collection, 1-6 History, n.d. 1921-1969, Archdiocese of Detroit Archive.

92 William Thompson, "Letter from the Bishop about a Lien on the Church," Church Matters, January 16, 1926, St. Paul Parish Collection, 1-3 Correspondence n.d., 1921-1937, Archdiocese of Detroit Archives.
} 
in Detroit is very sad." He continued in a condemning manner against Fr. Borg stating, "Everyone seems to have his own story to tell why he dislikes the Pastor...but to me Father Borg is not to blame completely \& absolutely, for practically he knows no better...to me he is mentally defective, he is sick, he is not himself any longer... When he himself told me that twice on one Sunday he called the Congregation "a lot of bullshit" - pardon me - I could only make the sign of the cross, tell him that he was crazy \& very imprudent - \& turn to a corner \& laugh. ${ }^{" 93}$ The letters, mismanagement of funds, and emergence of the conservative Fr. Cefai led to the end of Fr. Borg's time at the head of the Maltese parish in 1927.

Father Cefai remained the official parish priest for nearly three decades. Despite his longstanding post, Father Cefai's time at the head of the Maltese Church in Detroit brought out a similar divide in the community. Many ethnic parishes around the city isolated themselves through adherence to traditional languages and held almost "tribal views of the outside world." 94 Father Cefai exacerbated those feelings. He railed against mixed marriages, these being marriages outside of the Maltese Catholic community, and shamefully admitted that he knew of "quite a number of Maltese that are happily married and their wives are Polish." 95 The division between the ethnic parish of the Maltese and other parishes attended by the Maltese around Corktown arose perhaps because of the services provided by Father Clement Kern at Most Holy Trinity. In what was one of the poorest parishes in the Archdiocese, Kern provided a school, medical and dental clinic, English and Spanish language learning programs, legal services and a “Corktown Co-op" which was a parish sponsored salvage business. ${ }^{96}$ These services attracted the

\footnotetext{
${ }^{93}$ Michael Cefai, "Letter from Fr. Cefai about Mission,” Personal Letter, March 19, 1926, St. Paul Parish Collection, 1-3 Correspondence n.d., 1921-1937, Archdiocese of Detroit Archives.

${ }^{94}$ Tentler, Seasons of Grace, 424.

${ }^{95}$ Ibid.

${ }^{96}$ Ibid., 393.
} 
Maltese living closer to Most Holy Trinity to favor that parish over St. Paul's. The good work of Most Holy Trinity made the job of uniting the Maltese Catholics under one parish even harder for Father Cefai.

While this divide played out in the upper echelons of Maltese society between the leaders of the church and local community clubs, it was a divide that did not matter much to the average Maltese family. The women of the Trinity Club were a great example of this. The events they held were located at St. Paul's, even though many of them worshipped at Most Holy Trinity. ${ }^{97}$ Despite Father Cefai's wishes that the Maltese would all attend one church, the Maltese often attended the church that seemed most convenient on a regular basis, handling their religious business in a manner separate from the Maltese Church. Either way, pro or anti Fr. Borg, the establishment of the Church created a foundation of a Maltese culture in the community. Into the late 1920s and through the 1930s, the Maltese community attended Vaudeville shows and community plays in the Maltese language and Sunday mass together at St. Paul's. ${ }^{98}$ The fact that community members united at St. Paul's showed the importance of the physical church location, despite members worshipping at other parishes.

The assimilation forces working on Maltese families, aided by their positions in the city, jobs, and the Church, manifested in several ways. One of the more prominent ways was through an emerging love for baseball, specifically the Detroit Tigers. Part of this love grew from proximity to Navin Field, the home of the Tigers located on Michigan Avenue and Trumbull, just blocks at most from many Maltese in Corktown. With the stadium expanding over the decade, and a lack of parking for automobiles, families all across the neighborhood opened their lawns to spectators. Charging just a few cents a car, many Maltese recall their parents having as

\footnotetext{
${ }^{97}$ Dianna Gale Andreassi, Maltese in Detroit (Charleston, S.C.: Arcadia Publishing, 2011), 9.

${ }^{98}$ Mary and Charles Brincat, interviewed by author, March 9, 2014, Detroit, Michigan.
} 
many as five cars in the yard for each game. It created a small influx of income, perhaps just some spending money on the side, but income nonetheless. ${ }^{99}$ And for many, particularly the men, this transitioned into a love for baseball. Watching American men flock to the stadium day in and day out for the entire summer, Maltese men believed adopting American culture meant understanding and loving the sport of baseball. Rose Mifsud recalled her father, Emmanuel Muliett, insisting that he be home, sitting in his chair next to the radio, for the broadcast of every Tiger's game. ${ }^{100}$ For Emmanuel, this was his embrace of America. His home was so close to the stadium that they could often hear the roar of the crowd outside their home before it came over the radio.

Finally, by the late 1920s and early 1930s, several Maltese families began to purchase land away from the city. Several different locations drew them out of the city, places like Walled Lake, north-west of the city, and Lexington, 80 miles north of Detroit. In some cases, families began to erect homes in proximity to lakes around the region, although the Great Depression severally slowed this construction. ${ }^{101}$ The act of purchasing new land, and beginning the process of home building for the sole purpose of recreation, portrays a level of astonishing economic security for a group of migrants who in most cases had settled in the United States for only a decade.

The migration of Maltese to the United States in the 1920s represents something of an anomaly on both sides of the Atlantic. Geographically and religiously speaking, Maltese should have been severely restricted by the Immigration Acts of 1921 and 1924, and yet their British association helped alleviate - eventually - the most drastic of those restrictions. That same

\footnotetext{
${ }^{99}$ Ibid.; Rose Mifsud, interviewed by author, June 1, 2016.

${ }^{100}$ Rose Mifsud interview, June 1, 2016.

${ }^{101}$ Rose Mifsud interview, June 1, 2016, Joseph Brincat, interviewed by author, June 2, 2016, Farmington Hills, Michigan.
} 
association, as British subjects, opened doors once in the United States to assimilate at a very rapid rate. The community that formed in Detroit accelerated that process as well. The formation of a Church community so quickly created a stabilizing institution that not only offered spiritual but also social guidance. So important was this institution that it became a battle ground over ideology among the Maltese in Detroit. All-in-all, the success of finding good paying jobs, establishing social and religious foundations, and then embracing their new homeland ultimately created an immigrant that was much beloved in the city of Detroit. 


\section{Chapter 6 - Community Challenges: Depression and a World War}

The chimes of bells emanating from church towers, both the large cathedrals and the small village churches, echo particularly loud across the limestone structures on the islands of Malta and Gozo. Three hundred and fifty-nine churches exist across the isles representing nearly three churches per square mile. This density of churches in Malta sprang from a long, complex history with Roman Catholicism. The core beliefs of the religion were brought to the islands in 60 A.D. when Paul the Apostle was shipwrecked on Malta. Since that time, the Maltese have clung fervently to their Roman Catholic traditions. Subsequent events, particularly the rule of the Order of St. John, strengthened that bond between religion and people. Even when Malta welcomed British rule, the Church remained a bulwark of Maltese culture and society. A century later when the Maltese began to emigrate to North America, the Church continued its role as both a cultural and community adhesive. Those migrants who left their home and settled in the United States and Canada were first tutored by the Church in Malta. Once abroad, they used the Church extensively to build a community in North America as well as a means of communication to Malta.

This chapter examines how the Catholic Church stood firm as a source of continuity in Malta and North America. In Malta, the growing "Language Question," a political discourse over the use of Italian or English in official documents, spiraled out of control, ultimately turning into a crisis of Empire. Most importantly, the Church remained cautious of its involvement in the spat. ${ }^{1}$ Though political partisans attempted to use Church figures to manipulate Maltese public

\footnotetext{
${ }^{1}$ It was not always the case however. In fact, the ruling party led by Lord Strickland in Malta came under intense pressure from the Archbishop of Malta, leading to an attempt on Strickland's life - which nearly succeeded. The row was mediated by both the British and the Pope at the end of 1930. From that point on the Archbishop and clergy of Malta were placated as far as domestic politics were concerned and showed consideration of their political
} 
opinion, the Church struck a cautious tone. This tone carried overseas to the Maltese communities in North America. While the "Language Question" received some play in the United States and Canada, it was largely stifled by both the Great Depression and the greater need to create community organizations. It was through the Church that the communities in Detroit and Toronto built social organizations and community cohesion, led by priests who mirrored their brethren in Malta by focusing on the development of community rather than politics. This drive to create stable and prosperous communities through social organizations greatly aided the accommodation process in North America. During the Great Depression, signs of Maltese integration were prevalent, particularly in Detroit.

Ultimately, the successes of community building were in full display during World War II. With Malta besieged, the newly created community organizations, led by local Churches, raised tremendous sums of money and donations to support their native homelands. A handful of Maltese had risen to national prominence as performers and used their star power to bring attention to their beleaguered homelands. Their successes in raising capital and bringing in Maltese star power illustrated great promise for the future of successful Maltese communities in North America. Maltese men and women worked good jobs, served in the American and Canadian Armed Forces, bought vacation properties, and fully embraced their new lives. By the end of World War II it was also clear that the Maltese parishes in North America held considerable power and sway within these respective growing communities. However, that power would not necessarily last, especially in Detroit where an overreach of the Church resulted in serious community backlash at the end of the war.

pull within the populace. "3 Shots Fired at Lord Strickland in Malta; Attack on Premier Fans Church-State Fight," New York Times, May 24, 1930. 


\section{The Language Question}

While the Great Depression dominates the 1930s narrative, other events, like the brewing international tensions, helped to shape the Maltese communities. Politically, the swirling question that dominated the 1930s in Malta was that of the "Language Question." The issue generally revolved around the use of Italian in both private and public forums across the island territory. The use of Italian, and a creeping Italianate culture, presented clear dangers to the meticulously crafted British identity on the islands. Malta's obvious closeness in proximity to Italy gave some credence to the theory that Maltese people were historically an "Italianate" people. Despite this geographic and religious proximity, Italian influence over the previous forty to fifty years had waned in Malta. The reliance of Maltese labor on work emanating from the British-run dockyards allowed an economic acculturation to occur, pulling Maltese away from their closer geographical and religious cousins just sixty miles away in Sicily. This economic acculturation created a class of Maltese labor who viewed their level of economic comfort intimately tied with British rule, and thus stood in opposition to the Nationalists. ${ }^{2}$

However, England's lackadaisical attitude towards the Italian cultural creep allowed it to reemerge, and by 1930 the "language question" intensified. The issue of Malta's self-rule furthered the difficult decision making. By 1932, the Governor continued to report increased activity of Pro-Fascist Italian activities in popular areas such as the Royal Opera House inside Valletta. ${ }^{3}$ Very quickly it was felt that England must act or watch Malta "pass into the Italian

\footnotetext{
${ }^{2}$ Henry Frendo, "The Naught European Twins of Empire: The Constitutional Breakdown in Malta and Cyprus, 1930-1933," The European Legacy, (Vol. 3, No. 1, pp. 45-52, 1998), 50.

${ }^{3}$ Sir Harry Luke, "Telegram from the Governor," 27 October 1932," MSS Brit. Emp. S286, Luke, Box 2 , Weston Library - Bodleian Libraries, University of Oxford, Oxford, England. A Response to the governor advises him to politely reject the invitation to attend the Fascist celebration as it could be misinterpreted but not to stop the event from happening.
} 
cultural orbit" which could only end with Malta passing "into the Italian political orbit as well." 4 The papers of Sir Harry Luke, Lieutenant Governor of Malta, suggested that the majority of these feelings of Italian culture were manufactured primarily as a vehicle to carry anti-British sentiments rather than reflecting an actual historical attachment. Thus, from London's point of view, the "Language Question" became an imperial question challenging Britain's hold on Malta during the rise of Mussolini.

With war against Italy potentially on the horizon, British officials attempted to play down the "Language Question" in public while investigating it further. ${ }^{5}$ The British publicly continued to argue there was little appetite by Maltese for the Italian language in their day-to-day lives. The belief was that the general populace, who were believed to be staunchly pro-British, preferred to use the Maltese language in their day to day lives rather than Italian anyway. ${ }^{6}$ But the issue was pushed hard by the Nationalist Party and, in particular, a small sect of pro-Italian individuals within the Nationalist Party of Malta. ${ }^{7}$ Sir Harry Luke wrote worryingly in the early 1930s that his newly created secret service had exposed more truth to the pro-Italian movement than most officials previously knew, or were willing to accept. ${ }^{8}$ For many within the British ranks, this revelation forced many to consider if Maltese self-governance was worth the political price.

\footnotetext{
${ }^{4}$ Sir Harry Luke, Secret document from Governor David G.M. Campbell, 25 October 1932, MSS Brit. Emp. S286, Luke, Box 2, Weston Library - Bodleian Libraries, University of Oxford, Oxford, England, 3.

${ }^{5}$ Sir Harry Luke, "Notes for the Royal Commission," MSS Brit. Emp. S286, Luke, Box 1, Weston Library - Bodleian Libraries, University of Oxford, Oxford, England, 6-8.

${ }^{6}$ Frendo, "The Naught European Twins of Empire," 50. Frendo's comparison of the case of Malta and Cyprus in the 1930s focuses on the issue of language. While Cypriots conversed and used Greek in their everyday experiences, Maltese only used Italian in public affairs and official communications, reverting to the Maltese language for everyday conversation. The formalization of the Maltese language in the 1930s was supported, according to Frendo, by the British. Their support for this formalization allowed the language to become "anglicized and de-italianized." Frendo calls this a "sociolinguistic key to recoverable loyalism" that the British could then deploy.

${ }^{7}$ Luke, "Notes for the Royal Commission," 6-8.

${ }^{8}$ Ibid.
} 
The "Language Question" permeated Maltese society, even if the British played down its significance in the local population. Ultimately, the issue - even at the local level - was never about language. It was always a political question, and an important one at that. The Italian government attempted to sway the Maltese public against Britain through funding Italian Culture Centers across the islands and even - according to Sir Luke's secret service - paying members of Malta's opposition party, specifically the head of the Nationalists, Enrico Mizzi. ${ }^{9}$ The ruling party, led by Gerald Strickland, struggled in its own right, openly fighting with the Catholic Church before making public apologies..$^{10}$ This strife, something London sought to avoid at all costs, allowed the imperial problem to grow. Strickland's party, despite being pro-Empire, became impossible to work with from London's point of view. The inability to reach either party during the early 1930s only damaged the Imperial image. ${ }^{11}$ Eventually Luke succumbed to the idea of not just suspending the Maltese constitution, which was done in 1930, but withdrawing the constitution completely while London drew up a new constitution which took nearly all the power from local government. In 1933, the constitution was withdrawn and Malta returned to

\footnotetext{
${ }^{9}$ Sir Harry Luke, "Secret Document," 28 October 1932, MSS Brit. Emp. S286, Luke, Box 2, Weston Library - Bodleian Libraries, University of Oxford, Oxford, England, 1-2. The secret document, of which there are several in Sir Harry Luke's papers, discusses that "Malta is now just like an Italian Provincial city" with "propaganda increasing rapidly." The document, written based on discussion with a "most reliable" informant claims that only Mizzi favoured the propaganda but only for money, "He does not, however, do it, as so many people believe, for idealistic purposes but because of the hard cash he obtains." The document later suggests that the voluntary Italian language courses were seen as an impending failure by Mizzi, so much so that he had hoped the British Government would forbid them so the Nationalist party could save face on the entire scheme.

${ }^{10}$ Frendo, "The Naught European Twins of Empire," 47. Noted by Frendo was the "suspension of Malta's general election and of the self-government constitution in $1930 \ldots$ blamed on political interference by the ecclesiastical hierarchy, who made it sinful to vote for the outgoing government party led by Lord Strickland...Strickland had exacerbated if not invented a casus belli concerning a visiting Italian ecclesiastic: the Vatican and the Pope himself became directly involved in a vicious quagmire that greatly strained relations between Britain and the Vatican."

${ }^{11}$ Luke, "Notes for the Royal Commission," MSS Brit. Emp. S286, Luke, Box 1, Weston Library Bodleian Libraries, University of Oxford, Oxford, England, 12. Luke writes about Strickland's government in Malta, "I must add that one of the chief difficulty of dealing with Strickland and his Ministers is that they continually pose as the party that is loyal to the Empire and claim that in consequence they should invariably be supported by the Imperial Government. It is a case of save me from my friends. During this past winter I have gradually been forced to the conclusion that Strickland is a bad client and that he does more harm than good to the Imperial connection."
} 
Crown Colony status until 1936. In theory, this action safeguarded imperial interests on the island. $^{12}$

The British Government in 1936 made sincere efforts to stabilize Malta for economic and military purposes. To achieve that would require bringing Maltese people firmly into their European-Britisher status. An official change in attitude towards locals was issued as part of a pro-Empire response accompanying the new constitution. ${ }^{13}$ Sir Charles Bonham-Carter, Governor of Malta in 1936, gave a lengthy address to new military officers and their accompanying units upon arriving in Malta for the first time. In the address he reminded the officers that, unlike the rest of the entire empire, Malta was not comprised of "coloured and nonChristian" peoples but rather was "the only colony in the British Empire in which the inhabitants are European...there is no other." ${ }^{14}$ Even with this categorization of Maltese as part of the whiteEuropean sphere, he implored the men further, noting,

It is of enormous importance to the Empire that Malta should never be in danger of capture by an enemy. I am convinced that a failure to hold Malta would mean the end of the British Empire... The Maltese would soon become aggressively British if our Government and those of the Dominions were to treat them exactly in the same way as we treat each other, in fact, in every way as our equals...let us make some amends now and repair the evil which our predecessors in Malta have wrought by a racial exclusiveness that did much harm. If you do so, you will find I am sure, that your advances are met more than half-way and you will make pleasant friends and acquaintances, and you will be doing a service of great value to the Empire. $^{15}$

\footnotetext{
12 Ibid., 15-16.

${ }^{13}$ Revisiting Leo Amery and his conception of Empire, one can follow his views - by giving people economic opportunity and stability they will politically find cause to remain within the Empire - transpiring in Malta. Further, Amery viewed Malta and Palestine as inhabited by "white" European peoples, perhaps largely for the military necessity of these outposts. William Roger Louis, In the Name of God, Go!: Leo Amery and the British Empire in the Age of Churchill," (London: W.W. Norton \& Company, 1992), 18-20.

14 "Sir Bonham-Carter address to the Troops, 1936" in Sir Henry Luke, Box 3, Weston Library - Oxford University, Oxford, England, 7.

15 Ibid., 8-9
} 
Winning the hearts and minds of Maltese both in Malta and abroad took more than turning the other cheek when it came to political and social interaction between the Crown and the people.

Despite the general agreement made with Britain to remain out of politics in Malta, the Catholic Church heavily influenced the Maltese people. The Fascist government in Rome sought to use the imagery of the Church to spread a pro-Italian vision. A visit of the Maltese Archbishop to Rome highlighted this plan in action. The Archbishop was taken to Sicily from Malta via R.A.F., and once in Rome the Italian Air Force suggested he fly back to Malta in an Italian aircraft, escorted by several seaplanes. However, having just ironed out a new peace accord with the British government in Malta in 1930, Pope Pius XI cautioned otherwise, telling the Archbishop, "You must refuse this offer immediately. They are not doing it out of deference to you or myself but merely to show the Italian uniform and a squadron of Italian seaplanes in Malta and to impress the people." ${ }^{\prime 6}$ Stirred into action by the Italian advances through yet another route, Sir Luke further wrote that “The time has perhaps now come when His Majesty's Government might wish to consider the advisability of counter propaganda." 17 These questions the language question, the constitutional questions, and the issues of propaganda - began to affect all Maltese globally.

The political life of Malta ran through the various publications that circulated through communities in North America. Therefore, the "Language Question" seeped over the Atlantic. In November 1935, The Maltese Journal, a monthly newspaper distributed throughout North America, ran an article in Italian titled "Corriere d'America." The article, a reprint from an Italian article published on October 6, 1935 claimed that the "unfortunate Maltese under the

\footnotetext{
${ }^{16}$ Sir Harry Luke, "Secret document From Edward R. Mifsud, Secretary of the Maltese Imperial Government," 10 October 1932, MSS Brit. Emp. S286, Luke, Box 2, Weston Library - Bodleian Libraries, University of Oxford, Oxford, England.

17 Ibid.
} 
English Play, invoke their Mother Italy." ${ }^{18}$ The same article argued that the Nationalist Party, despite British propaganda, were the educated and in the majority in Malta, noting that they won the 1935 election before England suspended Malta's constitution. ${ }^{19}$ Furthermore, the party under Strickland was largely composed of illiterates and those paid by the English. It concluded by stating, "We are assuredly, with and for Italy in whatever undertaking. Let Mussolini’s government inject into savage Ethiopia latin civilization, wash away the old redresses and vindicate the bloodshed, showing to the jealous world how even today Africa trembled at the mention of Rome." ${ }^{20}$ That The Maltese Journal chose to run that article clearly put the publication in the anti-British camp, at least for the moment, a strange position for those in North America given their benefits from association with the Empire.

\section{The Great Depression in Detroit and Toronto}

Even if certain publications within the Maltese community pushed the Italian agenda in North America, it never held overwhelming prominence in North America. Life in the United States and Canada came with its own set of continental issues that had to be confronted and dealt with as newly minted North Americans. Even though they remained connected to Malta through letter writing and the Maltese press, there were new challenges and priorities. Foremost, the language priority for the Maltese in North America was English, not Italian. English was crucial for everyday life in Toronto and Detroit. Many of the young children learned both English and Maltese, and only used Italian if they had Italian family members. Established in their new communities, it made the "language question," at its core meaning - a change of emphasis of

\footnotetext{
${ }^{18}$ The Maltese Journal, November 1935, Microform, MG 28-V76, R4455-0-4-E, Library and Archives Canada, Ottawa, Ontario, Canada; Vol. 1, No. 6, 1.

${ }^{19}$ Frendo, "The Naught European Twins of Empire," 47. Frendo suggests that the Nationalist Party was likely on track to win the suspended election of 1930 as well.

${ }^{20}$ The Maltese Journal, November 1935, 6.
} 
language in Malta - less important than certain mouthpieces wished. At the very least, the debate transformed in North America as advocates for Maltese nationalism supported the pro-Italian camp.

As the Language Question deepened in Malta, the lack of new migrants to North American kept the debate limited to small publications whose ties reached back to the islands. The advance of the Great Depression brought a halt to most of the emigration from Malta. Not only did the Depression halt new migration, but made return migration more difficult due to the limited resources available to the Maltese, particularly those in the United States. The Maltese Journal discussed the economic troubles of migrants and their quest for citizenship in an increasingly nationalist America. ${ }^{21}$ Additionally, the paper outlined the types of services available to Maltese British Subjects in the United States, writing "British Consular officers in the US... are available...for a variety of services, but not for hardship relief which Maltese can get through their local governments. If an individual has fallen on hard times and is looking to be repatriated to Malta, 'such cases as are brought to their attention and found worthy of consideration are referred to the Government of Malta...in view of the heavy unemployment prevailing in the Islands the authorities in Malta very rarely feel justified in acceding to the applicant's request." ${ }^{22}$ It seemed that the 1930s not only brought hardship, economic and political, but additionally it made the separation from their homelands more permanent. Both Canada and the United States felt the crush of Depression hard. For those in Toronto, life was difficult but many found some way to remain employed even if it meant finding creative employment. Those who had lived in Canada for a lengthy period of time were better positioned to find some type of work during the Depression. Someone like Sam Coleiro

\footnotetext{
${ }^{21}$ The Maltese Journal, July 1935, Vol. 1 No. 2.

${ }^{22}$ The Maltese Journal, October 1935, Vol. 1, No. 5, 8.
} 
who came to Canada in 1918 initially struggled to find work as the Depression set in. But in 1931, he found work at the Dominion Tar and Chemical Company, a paper mill in the city. He would work at "Domtar" for 36 years before retiring. ${ }^{23}$ Lawrence Sapiano, a more recent migrant to Toronto, coming in 1926, was laid off from work with the Hydro company. Luckily for Sapiano he was able to quickly find work with Swift Meats, stuffing sausage into casings for \$710 per week, depending on how much overtime he was able to accrue. He recalled the work as laborious. Starting at seven o'clock sharp, a half hour for lunch - being watched by the foreman to make sure the workers were promptly returned to the line by noon, and worked until fivethirty. He bemoaned it for being "hard [work] and damp, and hot, and cold, and uncomfortable." 24 The pay was so low that the workers could not afford to take the street car, walking to the factory even in the depths of the harsh Toronto winters. ${ }^{25}$

While many could find piecemeal work, not all men were lucky enough to retain their preferred line of work throughout the Depression however. Martin Cachia's father was one of those unlucky laborers. The senior Cachia relied on the city government for odd jobs, being sent all around the city for random deployments if he was lucky. The day to day jobs were unremarkable, but what Martin remembered most was his father riding a bicycle to work every day with a basket on the front. If Cachia was lucky, upon returning home the basket would be filled with bits of wood or coal. To obtain the bits of scrap, he would stop at the railway by Massey-Harris every day to scavenge for pieces of coal that had fallen off the day's trains or

\footnotetext{
${ }^{23}$ Mr. Sam and Mrs. Carmela Coleiro, interviewed by Richard Cumbo, March 13, 1978. Toronto, Ontario, Canada. Multicultural Historical Society of Ontario Archives, MAL-2854-COL, Box 138, Maltese C-S.

${ }^{24}$ Mr. Lawrence and Mrs. Pauline Sapiano, interviewed by Richard Cumbo, March 6, 1978. Toronto, Ontario, Canada. Multicultural Historical Society of Ontario Archives, MAL-2852-SAP, Box 138, Maltese C-S. 25 Ibid.
} 
even pieces tossed out by train engineers. With these scraps, they would heat their home. ${ }^{26}$ This scavenging took care of one major essential, warmth, but feeding families - particularly large families like the Maltese typically had - proved more difficult.

As the Depression wore on, feeding those in need turned into a political debate. According to Sylvio Cachia, brother of the aforementioned Martin, one of the critical shortages in the city was milk for children, a commodity rationed by the Canadian government. Sylvio was one of five children in the Cachia family. Despite the family's size, they were allocated just a quart of milk per day. He lamented that the government only gave "what they thought you need[ed]." ${ }^{27}$ The Maltese, like other communities, turned to the good will of Toronto's major factories. Sylvio praised Massey-Harris, the tractor company, for its work in feeding people. Massey-Harris worked with Silverwood Dairies in Toronto and the two companies took up the slack, distributing extra milk to the people of Toronto who were in desperate need. Come Christmas time, Massey-Harris even distributed boxes of food to those unemployed. This philanthropy earned Massey-Harris a good name within the city. ${ }^{28}$ Despite these hardships, the Toronto community kept an eye on the future as they continued to save for a new church and community center.

The Maltese in Detroit felt the ravages of Depression as well. There, Maltese skilled laborers who had found a niche in the job market struggled to keep that edge. The Depression became a great equalizer. Maltese men felt the grips of the economic downturn like others in the city. Men who previously had employment, like Mary Brincat's father were reduced to

\footnotetext{
${ }^{26}$ Maria C. Cachia, Martin Cachia, Sylvio Cachia, interviewed by Richard Cumbo, February 10, 1978. Toronto, Ontario, Canada. Multicultural History Society of Ontario Archives, MAL-2847-CAC, Box 138, Maltese C-S.

${ }^{27}$ Maria C. Cachia, Martin Cachia, Sylvio Cachia, interviewed by Richard Cumbo, February 10, 1978. 28 Ibid.
} 
journeying back and forth between New York and Detroit attempting to find any work available.

The Brincats relied on an informal network of cousins and other friends who could, for the moment, house the family while the father attempted to find work in one of those two cities. Mary recalled living in a crowded New York City apartment complex filled with other Maltese and immigrants from across Europe ${ }^{29}$ After a year of fruitless searching the family returned to Detroit where they lived with Mary's grandmother. Her father, at the time illegally in the United States, was able to legally emigrate to Canada and did so, moving to Windsor while the family stayed with their grandmother in Detroit. This separation was only temporary as Brincat received his immigration papers for the United States in the late 1930s ${ }^{30}$ This sort of pooling of resources and reliance on familial networks was essential for many, and universal across North America, in order to survive the roughest of times. ${ }^{31}$

As the Depression deepened, labor unions rose to prominence, particularly in Detroit. There is little doubt that Maltese men who worked in the auto industry of the 1930s took part in some types of union activity, even if it was simply signing a membership card. But some of the most noted moments of activism came not from Maltese men but from Maltese women. Swept up in the growing union activism of southeastern Michigan, women across Detroit joined in solidarity with ladies from across the workforce. A strike by Polish-American cigar factory women in Detroit in 1936 caused a chain reaction. ${ }^{32}$ As part of the ongoing strike, Carmen Pace,

${ }^{29}$ One of Mary's memories of living in New York City was the manner in which the apartment building communicated when Immigration Officials entered the building. She recalled that anytime an official entered, everyone would use a broom to knock on their ceilings, a warning to hid anyone - like her father - who were illegally in the country.

${ }^{30}$ Charles and Mary Brincat, interviewed by author, March 9, 2014, Detroit, Michigan. Furthermore, Mary recalled having to hid her father in the coal cellar or "Michigan basement" when immigration officials were on the block in Detroit and her father was visiting from Windsor.

${ }^{31}$ Lizabeth Cohen, Making a New Deal discusses the struggles of ethnic communities in the United States, particularly Chicago.

${ }^{32}$ These strikes were organized shortly after the great successes of the Flint sit-down strikes, which also occurred across Detroit in auto plants. The women working in the cigar factories of Detroit, largely Polish 
Rita Borg, Iris DeCarlo and a handful of other Maltese girls working at the American Lady

Corset Company on Fort Street in Detroit joined with workers across the city in several sit-down strikes. ${ }^{33}$ This type of activism from industrial women became commonplace in the 1930s, with one of the greatest examples emanating from Flint's famous sit-down strikes, where women played vital roles picketing outside the factory and supplying men inside the plants. ${ }^{34}$

Even as the world changed around them and Maltese were represented on the frontlines of labor battles, some did so from a more comfortable position than others. Emmanuel Muliett, the former electrician from the Royal Dockyards, retained his work throughout the Depression as an electrician for Chrysler. Rose Mifsud, his daughter, recalled that he was able to do so because of his profession, that even in the darkest days of the economic downturn, Chrysler still needed highly trained men. But the Mulietts did not come through unscathed; Emmanuel took a hefty pay cut. Rose expressed this cut saying, "We never had a lot of everything, but we weren't depressed...We didn't have to scrounge for food you know..." ${ }^{35}$ Even the act of holding a job, however, separated the Muliett family from many others in their immediate neighborhood. The family was generous with their scant resources, taking in those who lost their homes and hosting dinner for friends every Sunday. Despite that, bitterness in the Corktown community still swirled towards those who held jobs. Rose attributed some of that to a desire to fulfil their duties to the

immigrant women, took heart from those successes and sought to achieve similar results. The Cigar workers of Detroit were chartered under the CIO as "Cigar Workers Local No. 24" in 1936 and their success furthered the spread of strikes and unionization in other women dominated industries across the city like the "National Biscuit Company, the American Lady Corset Company [where these young Maltese women worked], the Yale and Town Manufacturing and stores like shoe stores, drugstores, department stores, and hotels." Nowak, Margaret Collingwood, Two Who Were There: A Biography of Stanley Nowak, (Detroit: Wayne State University Press, 1989), 38-40.

33 The Maltese Journal, April 1937, Vol. 3, No. 4, 5.

${ }^{34}$ For more, see; Sidney Fine, Sit-Down: The General Motors Strike of 1936-1937 (Ann Arbor: University of Michigan Press, 1969). Fine's work on the Sit-down strikes in Flint during 1936-1937 is one of the better works on the topic.

${ }^{35}$ Interview with Rose Mifsud, interviewed by author, June 1, 2016, Farmington Hills, Michigan. 
Catholic Church. She mentioned that some "people that did have large families...still gave to the Church fund when they needed it for their table," further sapping their meager incomes. ${ }^{36}$ But the Muliett family was not alone in keeping some semblance of normalcy during the tough times.

Others in the Maltese community went beyond simply holding their jobs, and began to take steps towards expanding their businesses or entering professional positions. In the depths of Depression, the Maltese still congregated in neighborhoods, and some began to establish businesses in the region. Anthony Cefai, younger brother of Fr. Cefai, the Maltese priest in Detroit, was sent abroad to study medicine. He returned to Detroit in 1937 to open a practice of his own as a newly minted physician. ${ }^{37}$ Dr. Cefai was part of a small, but growing, class of Maltese in the Detroit region that climbed the educational ladder rapidly. The Maltese Journal noted that another new physician opened a practice in the same year across the river in Windsor. ${ }^{38}$ This emerging class of professionals, coupled with those blue-collar Maltese families that were able to keep work, represented part of a growing and complex community aspiring to "make it" in their new homeland.

While some languished without work in Detroit, those who made up part of the comfortable classes with employment took what savings they had to invest in property. As the city of Detroit grew, so too did the idea of buying lake property "up north," cutting across ethnic lines. The cottage on the lake was a personal retreat from the congestion and heat of the city. The Maltese took part in the buying spree as well, snapping up land both near and far from Detroit. The Mulietts built a small cottage on Wolverine Lake in Commerce Township, just a short drive from the city. ${ }^{39}$ Other individuals like Louis Muscat, who was noted making upgrades to his

\footnotetext{
36 Ibid.

37 The Maltese Journal, December 1936, Vol. 2, No. 12.

${ }^{38}$ The Maltese Journal, August 1937, Vol. 3, No. 8, 4.

${ }^{39}$ Interview with Rose Mifsud, June 1, 2016.
} 
property on Lake Mundin, converted an old trailer into a full-blown summer cottage. The

Maltese Journal noted that "Louis made sure the ground which he purchased for the purpose was beautifully landscaped." 40 These individuals were just part of a growing push towards "lake country" in the depths of depression.

Others purchased land hours north of Detroit in Lexington, nestled on the shores of Lake Huron. A cadre of Maltese individuals, starting in 1933, bought lots in the "Great Lakes Beach Community," literally in some cases a stone's throw from Lake Huron. Joseph Pace, joined by Louis Falzon and Charles Mifsud, made the earliest purchases in 1933. The three men bought corner lots between Huron Bay Boulevard and Elm Road. ${ }^{41}$ Others, like Jack Mifsud, Carmen Grech and Louis Camilleri followed suit in 1935. Camilleri, whose cottage was on Cedar Road, was a shipping clerk with one of the major auto companies in Detroit. Soon enough he would found himself even further attached to the Great Lakes, working as a fireman on board the S.S. Marquette with a crew of Maltese and Canadian sailors. ${ }^{42}$ As the decade wore on others continued to buy cottages "up north" including Publius Cassar in 1937, Benevenuta and Charles Saliba in 1938 and Charles Galea in 1939. Unfortunately, Charles Saliba, who worked as a factory foreman, passed away shortly after the purchase in 1939, and his wife Benvenuta had to sell the cottage in $1940 .{ }^{43}$ Near or far from the city of Detroit, the Great Depression provided a

${ }^{40}$ The Maltese Journal, September 1937, Vol. 3, No. 9, 4.

41 "Great Lakes Beach Community," Sanilac County Register of Deeds, Sandusky, Michigan. These records come to me via Joseph Brincat, who spent several years in his own project investigating the community of Maltese that purchased property in Lexington. Brincat shared his fond memories of summers spent at his grandparents cottage in the community surrounded by other Maltese (and Greek) families. A thank you must also be passed on from Brincat and myself to the dedicated staff at the Sanilac County Register of Deeds who did very thorough and detailed work digging up records for the entire community dating back to its founding in 1931. Brincat has given them flowers and lunch on several occasions. I can only say thank you through this footnote.

${ }^{42}$ Series Title: Passenger and Alien Crew Lists of Vessels Arriving at the Port of Detroit, Michigan, 19461957; NAI: 4527443; Record Group Title: Records of the Immigration and Naturalization Service, 1787-2004, The National Archives at Washington D.C; Year: 1940; Census Place: Detroit, Wayne, Michigan; Roll: T627_1851; Page: 9A; Enumeration District: 84-335

${ }_{43}^{43}$ Year: 1930; Census Place: Detroit, Wayne, Michigan; Roll: 1036; Page: 3B; Enumeration District: 0144; Image: 982.0; FHL microfilm: 2340771; Ancestry.com. U.S., Social Security Applications and Claims Index, 1936- 
great opportunity for those who had the funds to invest in physical property. In many cases these new investments were second homes, underscoring the level of success many Maltese achieved in their brief decade and a half in the United States.

\section{Community Organization and the Catholic Church}

What aided the processes of integration into American or Canadian culture for Maltese, and many other ethnic communities, was both religious and secular community organizations. These organizations grounded the wayward immigrant by offering something at once familiar, the Church, as well as navigation through their new city landscapes. Both communities of Maltese established very similar organizational structures, however, there were major differences between how these structures were founded and subsequently how the community interacted with them. These interactions highlight how people within them reacted to the differences in adaptive pressures despite both a close physical and cultural proximity between the two communities. In Toronto, the community worked together to build societies and religious organizations that created an insular community. Meanwhile in Detroit, the community was much more individualistic. The Maltese Church in Detroit was beloved by the whole community and secular societies were so plentiful that they split the time and resources of the community. The foundation of these interactions and the use of these community organizations takes root in the late 1920s and early 1930s in both cities.

One of the great needs in any Maltese community overseas was the ability to have a Maltese priest in the city to handle religious ceremonies. Over the course of the 1920s, the Maltese community in Toronto only occasionally received a visit from Father Alphonse Cauchi, who lived in Philadelphia. His visits typically included mass at Mt. Carmen Church downtown,

2007 [database on-line]. Provo, UT, USA: Ancestry.com Operations, Inc., 2015. 
where the largest community of Maltese existed. As the decade wore on, one of the members of the Maltese Canadian Society of Toronto (MCST), Carmelo Baldachinno, wrote to Toronto's Archbishop Niel McNeil and pleaded with his eminence to call for a Maltese language priest to join the city full time. Baldachinno lamented that due to the lack of a priest, the community was in terrible shape on account of many people - particularly older folks - who could not make confession or other rites because they did not speak English well enough. ${ }^{44}$ Archbishop McNeil considered this request, and eventually turned to Father Cauchi. ${ }^{45}$ With pledged support from the community, Archbishop McNeil called for Fr. Cauchi to come permanently to Toronto in 1929 where he was lodged with whatever families could afford him a room. ${ }^{46}$

The construction of a Maltese Church in Toronto added another layer to the already prevalent divide between the downtown community and the Junction community. Father Lawrence Bonavia, who came to Toronto in 1948, recalled stories of this friction which he called "very natural." ${ }^{47}$ As Toronto expanded the question of where to locate the Church put a stamp on where the Maltese community would be centered for future generations. The downtown community was long established, with social clubs like MCST and others operating out of Mt. Carmen Church headquartered in the downtown. But the Junction was the new development of the city. Many of the downtown Maltese by 1929 bought homes and moved their businesses into the Junction. These included folks like Tony Scicluna who operated a grocery store downtown

\footnotetext{
${ }^{44}$ Carmelo Baldacchino, "Letter to Archbishop Niel McNeil," 8 April 1929, St. Paul the Apostle Parish Collection - Efforts to Establish a Maltese Church, 1917-1929. Archdiocese of Toronto Archives, Toronto, Canada.

${ }^{45}$ Fr. Lawrence Bonavia, interviewed by Richard Cumbo, February 17 \& 24, 1978. Toronto, Ontario, Canada. Multicultural History Society of Ontario Archives, MAL-2850-BON, Box 137, Maltese B. In an interview with Father Lawrence Bonavia, the priest of the Maltese community in Toronto during the 1940s-1980s, Bonavia praised Fr. Cauchi as the "saintly priest," furthermore he notes that Fr. Cauchi was called to Toronto only because of the organization of the Maltese Canadian Society of Toronto who were very well organized and professional. They performed a great service to the small community of Maltese in the city.

${ }^{46}$ Ibid.

${ }^{47}$ Ibid.
} 
on Gilmore Avenue but relocated to Eglington and Keele nearer the growing community in the Junction. Land was cheaper, and space existed to mold the community to the Maltese desires. The question ultimately boiled down to, as Fr. Bonavia recalled, is it right to put the Church in “the place [where] there are many Maltese, or is it better to build in a new surrounding?"48

Ultimately, after a Sunday night argument and a vote, the community decided to build the Church in the Junction. ${ }^{49}$ In near tandem with Baldachinno's letter asking for a Maltese priest in the city, the Maltese Canadian Society of Toronto moved forward in 1929 to purchase land in the Junction for the express purpose of building their own church. The two plots of land were located at 3224 Dundas St. West in the Junction. Undeterred by the onset of the Depression, they started to build a church. Because of the heavy involvement of the club to build the church, the club became known early on as Il-Kazin tal-Knisja [the club of the church]. ${ }^{50}$ During the process of construction, the newly settled Father Cauchi opened a temporary place of worship in the neighborhood. The priest performed his first official ceremony, a baptism, as head of the Maltese Church on Nov. 11, 1929 at St. John the Baptist on Dundas St. West. ${ }^{51}$

Buying the property was just the first step in building St. Paul the Apostle's Parish. In order to finance and facilitate the actual construction of the Church, Fr. Cauchi leaned on the community, and not just MCST. The image of an exhausted, but determined, Fr. Cauchi knocking on doors asking for donations stuck in the memory of Savarina DeBatista. She added

48 Ibid.

${ }^{49}$ Mr. Francis and Mrs. Carmela Camilleri, interviewed by Richard Cumbo, February 23, 1978. Mississauga, Ontario, Canada. Multicultural History Society of Ontario Archives, MAL-3509-CAM, Box 138, Maltese. Mr. Camilleri recalls being at the meeting where they decided to build the Church on the West End in the Junction. He remembers it being a Sunday night and "they were arguing and they voted and they got more votes to build up in West Toronto and the Maltese that used to live downtown around John's Street and McCall started moving up here after the church was built."

${ }^{50}$ Richard Cumbo, "Brief Historical Points and Dates of the Old Maltese Society of Toronto," Maltese Canadian Society of Toronto, History and Constitution, Archdiocese of Toronto Archives, Toronto, Canada.

${ }^{51}$ St. Paul the Apostle Parish Collection - Parish History, Parish Appointments, Archdiocese of Toronto Archives, Toronto, Canada. 
that this behavior drove people to develop a slight dislike for the Maltese priest, but no one faulted his work ethic. Her brother Anthony gave credit to Fr. Cauchi for persevering during the hardest times of the Depression to raise enough funds to build the basement of the Church, where at least mass could take place. ${ }^{52}$ Giovanna Borg owned one of those doors that Fr. Cauchi frequently knocked on for donations. Borg recalled that most everyone in the community gave what they could. Sometimes instead of money people donated items, particularly soap, and they would take turns going to scrub the floors of the church to keep up the community investment. ${ }^{53}$ Borg not only donated her money, but also her time, acting as the president of the Christian Mother's Society, an all Maltese women's group that actively supported the parish, including the sewing of drapes for the new building in $1931 .{ }^{54}$ The church was finally finished, decorated, and blessed for its first mass celebrated on Sept. 8, 1931, the Feast of Our Blessed Mother, Malta's national feast day. ${ }^{55}$

The differences between the development of the community's strengths in Toronto and Detroit were highlighted by the Depression. Unlike the Toronto community, the Detroit community only had nominal control over its Church. Because the Detroit community grew so large, so quickly, a Maltese priest and a Maltese Church very early were considered a necessity by the Diocese of Detroit. This meant that rather than a community driven and controlled

\footnotetext{
${ }^{52}$ Mr. Anthony DeBattista and Ms. Xaveria (Savarina) DeBattista, interviewed by Richard Cumbo, April 12, 1978. Multicultural History Society of Ontario Archives, MAL-2856-BAT, Box 138, Maltese C-S.

${ }^{53}$ Mrs. Giovanna Batista (Joan) Borg, interviewed by Richard Cumbo, February 19, 1978, Multicultural History Society of Ontario Archives, MAL-2848-BOR, Box 137, Maltese B. The community investment was such that when the foundation and floor was poured the Maltese community could not afford reinforced steel for the concrete so many donated their bedframes or headboards. Interview with Richard Cumbo, Interviewed by the author, September 17, 2017, Toronto, Ontario.

54 Ibid.

55 "History of St. Paul the Apostle Parish," St. Paul the Apostle Parish Collection - Parish History, Canonical Documents, Archdiocese of Toronto Archives, Toronto, Canada. Because of the heavy involvement of the club to build the church, the club became known early on as "il-Kazin tal-Knisja" or the club of the church (This is different from the Maltese community of Detroit who after asking the Diocese for a priest had little control over their church but rather had to default to the appointed priests. The only thing they controlled was, occasionally the priest by sending petitions to remove them at times)
} 
Church, the Diocese had a much larger role to play in determining the best practices for the parish. In Toronto, the willingness to donate community-purchased land and money to the Archdiocese gave the community members a stake in the parish. As the Toronto community built its Church, the Detroit community struggled openly to unite behind a single Church or priest. Their only ability to control the path of the Church existed through petitions to remove whatever Priest remained at the head. Father Michael Cefai, who replaced Fr. Borg in 1926, was unable to bridge the gap in the community. His own personal views on the community further exacerbated these divides. The territorial, almost tribal like attitude of Fr. Cefai drove other Catholic priests in Detroit to write to the Bishop, asking for him to mediate problems within the community. ${ }^{56}$ By the 1930s, the growing secularism, fueled by the growth and success of the community, meant that the community was not a monolith. It came together for major events, but the everyday minutiae of life was not solely Fr. Cefai's to administer. However, that did not stop Fr. Cefai from attempting to forcibly keep the community together by adhering to a vision of a future community he had developed. By leading the Maltese Church, Cefai had hoped to be the sole voice of authority within the community, deriving power from the pulpit. Much like the Italian question, the divide in Detroit was driven by ambition for control from a small segment. He certainly did not help his own case, as one example from 1933 showed. A Church Committee

\footnotetext{
${ }^{56}$ Of particularly note is a feud over the marriage rights of Maltese individuals. Fr. Cefai refused to marry a Mr. Charles Lanzon, a Maltese resident of Detroit who worked at the First National Bank in Detroit and was unable to attend mass hours thanks to his work schedule. Mr. Lanzon and his future bride, Violet Chetcuti, also a Maltese in Detroit, went instead to the former Maltese priest, Fr. Borg, to request permission to be married outside of traditional mass hours. The mass, conducted by Fr. Cajetan Diana of the Church of the Madonna, who worked with Fr. Borg, was protested by Fr. Cefai as he believed he was the only one who had rights to marry Maltese people in the city of Detroit. He writes to the Bishop, "The only people who know them and their respective families are the Maltese people of Detroit. And the only Church for the Maltese is my Church." Fr. Diana responded by saying ethnic claims should not be heeded, or he would claim all Italians in his Church and "would have to bother Your Lordship every other day with complaints." Further he mentions that he has many Maltese who attend his Church including the well-known Maltese-American boxer Oreste A. Waling and that these people were more than welcome at his church. Ultimately, he asks, "What could the Maltese Church seven and a half mile away do for them?" "Feud over Marriage," Series of letters, (December 1929), St. Paul Parish Collection, 1-3 Correspondence n.d., 1921-1937, Archdiocese of Detroit Archives.
} 
member wrote to Bishop Gallagher detailing the abuse of Fr. Cefai's position. It seemed, and was later confirmed through internal Church memos, that Fr. Cefai was using the name of the St. Vincent De Paul Society to throw dances, which included the sale of beer, for personal gain. ${ }^{57}$

The use of the Church as a social tool in Detroit was one way Fr. Cefai could keep tabs on his flock. Through the auspices of the Catholic Youth Organization, Fr. Cefai organized both a Young Men's Club and Young Ladies' Club in Detroit for Maltese youths. These clubs were given the resources of St. Paul's Maltese Church, using the auditorium as their meeting rooms. The clubs indulged in recreational events like basketball, table tennis, and other gym activities as well as musical opportunities, furnishing an orchestra which became well known in the community for its members musical talent. ${ }^{58}$ Keeping an eye on the youth of the community, whom Fr. Cefai ultimately hoped to pair together in a vain attempt to stop Maltese from marrying non-Maltese, was only one aspect of the Church's social outreach. St. Paul's Maltese Church was the main organizer for the community's annual excursion to Tashmoo Park on Harsen's Island. The "island" was a much larger geographical formation, the largest freshwater delta in the world. The annual retreat north of the city offered an escape from the sweltering summer heat of Detroit and Windsor, it included a trip on the S.S. Tashmoo up the Detroit River into Lake Saint Clair, a two-hour trip on one of the fastest ships in the Great Lakes. ${ }^{59}$ These types

\footnotetext{
${ }^{57}$ Mr. Sam Buhagiar writes in his letter to Monsignor Doyle that Fr. Cefai was throwing a "Dance and Beer Party, not a decent social party...this dance and beer party is financed by Father Cefai, and the profit of this shameful party is not for the benefit of the poor, no! But for his salary. He just only use the name of the St. Vincent DePaul, so the people go." Sam Buhagiar, "Abuse of Position for Fr. Cefai Salary," Community Letter, (September 29, 1933), St. Paul Parish Collection, 1-3 Correspondence n.d., 1921-1937, Archdiocese of Detroit Archives.

58 The Maltese Journal, December 1938, Vol. 4, No. 12, 3.

${ }^{59}$ Unfortunately, the S.S. Tashmoo would sink in 1936, ending 17 years of retreats to Tashmoo island by the Maltese Community. In 1937, the community would begin to host its annual picnic on Boblo Island, south of Detroit. Boblo became a great entertainment complex featuring rollercoasters and other amusement park type trappings. These events, Tashmoo and Boblo, were perfectly situated for community on both sides of the international boundary. Being islands in the Detroit River, straddling the international border, people in both Detroit and Windsor had boat access to the islands without having to cross the border. The Maltese Journal, August 1936, Vol. 2, No. 8.
} 
of social escapes fostered further interaction between Maltese individuals on both sides of the border and on the surface gave a united front to the Maltese community.

While the Maltese Canadian Society of Toronto earned the nickname, the Club of the Church, there was no deep connection between various community clubs and St. Paul's Maltese Catholic Church in Detroit. The clubs and the Church competed over the jurisdiction of social activities. James Robertson, President of the Maltese American Social Club in Detroit wrote "There is no adequate reason why we should not get together - work together - and keep together. Now is the time to put life and soul into this movement. To this end every progressive Maltese...is urged to kindle his enthusiasm and to take advantage of the present encouraging opportunity to get busy and help build his organization." 60 Through building organizations, particularly in Detroit, many small organizations grew. Successful or not, these programs and organizations strained resources of the community.

One of the more popular ways in which the secular community came together was through sport. The St. Mary Football Club of Bagley Avenue, along with the Ramblers F.C. and the Sons of Malta F.C. were all soccer clubs comprised mostly of Maltese migrants in Detroit. The city, home to such a diverse ethnic community, became a hotbed for amateur soccer during the Great Depression. It was predicted in 1936 that Detroit would be "the center of organized soccer this coming season." 61 These soccer clubs not only offered athletics but also, in a traditional Maltese sense, they became social clubs in their own right. ${ }^{62}$ The teams from Detroit

${ }^{60}$ The Maltese Journal, July 1935, Vol. 1, No. 2.

${ }^{61}$ The Maltese Journal, July 1935, Vol. 1, No. 2.

${ }^{62}$ Athletic Clubs in Malta, particularly soccer (football) clubs are often social clubs as well. These types of clubs generally speaking have a full service bar, social hall, and many even have food options particularly on the weekends. They are places to get quality food and beer at an inexpensive price for the local community. The Sons of Malta Football Club operated in this same fashion in the United States. Through the mixture of sport and social club, men and women from across the community come together to enjoy events. The 1938 celebration of Festa Vitorja on September $8^{\text {th }}$ in Detroit was sponsored by the club and massively attended, with over 500 guests at the yearly 
often left the city at least once a year making tours throughout the country, particularly focused toward New York City where they would match up with sister clubs similarly comprised of Maltese immigrants. In 1935, the St. Mary Football Club became the first team to travel to New York from Detroit. Many people in the city were "hoping [they] may see some mighty fine play." 63 The organized club from Detroit was to be met with a scrambled together cast of New York Maltese for a three-game series.

Integrating into American culture opened other avenues of competition outside of soccer. Maltese individuals in Detroit excelled in other prominent sports of the 1930s. Hailing from Highland Park, the small city nestled within Detroit, Edgar Waling was a well-known Maltese boxer. After taking a year off in 1936 from his boxing career, the Canadian-born twenty-twoyear-old, was back in the ring. Coming off an A.A.U. National Championship in 1937, The Maltese Journal noted that he was one of the most famous Maltese sportsmen in the United States. Waling's career record by 1938 featured ninety-three matches, winning an astonishing seventy-eight of those. The young boxer came from a line of prestigious Maltese boxers, being trained by his father, Oreste A. Waling (Azzopardi), who the Journal called "no amateur with the gloves." 64 There even was an avenue for Maltese to compete in dog breeding during the 1930s. The same publication wrote that Joseph Saliba, the old manager of Hamrun Spartans in Malta, now resided in Detroit and worked his way up through the sporting circles in the city becoming a member of the Detroit State Boxing Commisssion and being nationally recognized as a first-

\footnotetext{
dance. In addition to a dance and mass held at St. Paul's Maltese Church, the organization held various athletics events to entertain the crowd.

${ }^{63}$ The Maltese Journal, July 1935, Vol. 1, No. 2

${ }^{64}$ The Maltese Journal, December 1938, Vol. 4, No. 12, 3.
} 
class fancy dog breeder. His 1935 entry at the Morris \& Essex Show, 'Nanka Von Schwyn,' an 18-month-old German Shepherd, was judged the best in the American class. ${ }^{65}$

By the mid-1930s, Detroit was certainly flush with social clubs and community activities. The large community, well over five thousand by this point, partook in the social-athletic clubs as well as more benevolent societies. The Maltese American Social Club, one of the oldest clubs in the community, located at 844 Michigan Avenue, drove much of the activism, including the pooling of money for a Death Benefit Insurance policy by $1935 .{ }^{66}$ Led by Joseph Fasi, the Social Club greatly expanded its offerings during the latter half of the decade, opening a MalteseAmerican Social Ladies' Club and a Maltese-American Social Boy's Club. While the Maltese Journal claimed that these types of organizations were the first of their kind in the city, that was partially false given that similar clubs existed through St. Paul's Maltese Church. Regardless, their creation in 1938 were deemed "essential in our growing community." ${ }^{67}$ Ladies', Boys', Sporting, and Benevolent clubs were also joined by Dramatic Societies like L'Indipendenza, which performed multiple plays a year, including some like "The Great Patriot" and "Tosca" on September $8^{\text {th }}$ and September $22^{\text {nd }}$ of 1936 respectively. ${ }^{68}$

The growing secularism of Detroit's Maltese meant a greater contest for resources which played out in the upper echelon of Maltese society between the leaders of the church and local community clubs, it was a divide that was much muddier on the surface. The women of the Trinity Club provide a great example of this. The events they held were located at St. Paul's,

${ }^{65}$ Ibid.

${ }^{66}$ The ability of the Maltese to pool together resources during the Great Depression and launch something like a Death Benefit fund was quite impressive compared to other ethnic communities. According to Cohen, particularly in Chicago, ethnic communities' funds became increasingly squeezed by the Depression as supply of money (members donating) dried up while those using the money increased. Cohen, Making a New Deal.

${ }^{67}$ The Maltese Journal, January 1938, Vol. 4, No. 1, 3.

${ }^{68}$ The Maltese Journal, November 1938, Vol. 4, No. 11, 3. 
even though it is likely that they worshipped at Most Holy Trinity. ${ }^{69}$ Mary Brincat, and her future husband Charles, both recalled walking a mile every Monday to reach St. Paul's Maltese for catechism class and other religious courses, yet Most Holy Trinity was also part of their religious sphere, attending mass at that church as well as St. Paul's. ${ }^{70}$ Despite Fr. Cefai's wishes that the Maltese would all attend one church, the Maltese often attended the church that seemed most convenient on a regular basis, handling their religious business in a manner separate from the Maltese Church.

\section{World War II, the Great Unifier}

Despite a decade and a half of propaganda from Rome in the form of the "language question" circling Malta, on June 10, 1940 Italy declared war on Great Britain and by association, Malta as well. If Malta would not fall to propaganda, then it would be subjected to Italian force. To Rome's great disappointment, the Maltese responded with great British patriotism. One individual recalled that during the years leading up to the war that "many Maltese were favorably impressed by these overtures [Italian propaganda] and it was inevitable that they would find the seeming indifference of countries like Great Britain, Canada, and Australia somewhat significant." But after the war broke out, the Maltese swung decidedly in favor of Britain. "We suffered and died besides other countries of the United Nations because we knew their way of life was really best," asserted the Maltese Journal. ${ }^{71}$ That certainly was not a surprise; Malta's British identity was built over years and solidified at the commencement of World War II.

\footnotetext{
${ }^{69}$ Diane Gale Andreassi, Maltese in Detroit, (Mount Pleasant, SC: Arcadia Publishing, 2011), 9.

${ }^{70}$ Charles and Mary Brincat, interviewed by author, March 9, 2014.

71 The Maltese Journal, April 1944, Vol. 10, No. 4, 1.
} 
Malta's refusal to give into Axis control meant that its war saga played out to an international audience in the form of news reels as the Axis forces attempted to bomb the islands into submission. The little British outpost became the most bombed place in the Empire outside of London. ${ }^{72}$ The brave defense of Malta, a key lynchpin of the Mediterranean, earned Maltese men and women praise across the globe. The struggle of the Maltese during the war was recognized by leaders on a worldwide scale as President Roosevelt called Malta "one tiny bright flame in the darkness." King George the VI awarded the islands the King George Cross, the highest civilian honor in the Commonwealth on April 15, 1942 for their collective bravery. ${ }^{73}$ These well-earned accolades transformed the global perception of the Maltese, earning them a comfortable place in the British mind at the war's end.

On a personal level the war experiences in Malta haunted future migrants, playing a significant role in their desires to leave Malta at the conclusion of the war. Evelyn Mamo moved to New York City in 1946 with her family, before continuing to Detroit in 1951. Her father, a driver for the Governor, decided to leave Europe for the safety of North America and to join friends already in Detroit. But her war experience stayed with her even in Detroit. She recalled the horrifying siege vividly, having been nine years old during the war. She and her friends would stand on the roof tops of buildings to watch for the planes coming from Sicily. When they appeared, the girls would quickly run to the shelters yelling, "the bombs are coming!"74 Her assumption as a little child was that the planes were coming to kill her for reasons she could not understand. These thoughts raced through her mind as they ran frightened to the shelter of the

72 "Maltese of City Work to Aid War-Battered Native Island," Detroit Free Press, January 4, 1941.

${ }^{73}$ Joseph M. Lubig, Maltese in Michigan, 5. The George Cross now adorns the Maltese national flag, resting in the upper left hand corner of the flag.

${ }^{74}$ Evelyn Mamo, interviewed by author, November 19, 2012, Farmington Hills, Michigan. 
neighborhood Church, the most solidly constructed building in the neighborhood. ${ }^{75}$ Thousands of Maltese, like Mamo, were driven underground during the siege of the Second World War. Many lived underground in catacombs subsisting on poor quality bread and whatever scraps of food could be found.

Others who were slightly older, like Mary Grima, had to think of their young families in the midst of war. Mary, who migrated to Detroit after the war with her husband, married a native Maltese medic serving in the British Army, John Grima, during the war. She attempted to keep busy during the fighting by working as a housekeeper for other soldiers stationed in Malta, cooking and cleaning the housing quarters. But like Evelyn, Mary was drawn to rooftops and hillsides to witness firsthand the aerial combat, watching British Spitfires scramble to the defense of the islands. At times, too close to the action, she was forced to flee, running and diving into ditches to avoid gunfire. And like many others on Malta, she suffered tremendous loss. She recalled a friend's house, one she visited almost every day, but the one day she did not visit, the house was bombed and everyone inside was killed. For Mary and John, the war never got easier even as Malta was made safe by the Allied invasion of Italy. John was transferred from the front lines in Benghazi and Tobruk to Liverpool. Taking Mary with him, she became severely ill and the doctors in England told him bluntly, "Take your wife home or you are going to bury this woman here." John left the Army and returned his family back to Malta, in the process he lost “every penny," including his pension benefits, something Mary said she "never forgave him for." Thankfully for the Grimas, John's army pals in Liverpool gathered donations to help offset the trip home and provide some living expenses once back in Malta. ${ }^{76}$

\footnotetext{
75 Ibid.

${ }^{76}$ Mary Grima, John Grima II [son], Rose Grima-Cataldi [daughter] interview, interviewed by author, May 29, 2016, Chesterfield, Michigan.
} 
For those who remained stationed in Malta, life was incredibly difficult and often times deadly. Frank Mifsud's father worked for the British Army, keeping the spot lights and electricity running in Valletta. One night during the bombings, Mifsud's father was working when their battery was bombed. Mifsud and one other man were the only two to survive. Immediately he rushed out of the plant in order to keep loved ones away from the scene, fearing their reaction when they saw the scant remains of their husbands and fathers. This experience stuck with the Mifsud family. Frank's father and mother remained worried about their family even after the war, so much so that his mother denied him the opportunity to travel to England to join the Naval Academy, instead making him serve in the local Maltese naval regiment, a less prestigious opportunity. ${ }^{77}$ After spending time in the Royal Navy, Frank decided to move to Ontario where he worked first in Windsor and then Sarnia, Ontario.

As the war went on, communities in North America had deep influence on the aspirations of people in Malta. Not only did people in Malta dream of one day escaping the horrors of war for the safety of the United States or Canada, often encouraged by their relatives already living abroad, but also they heard positive assessments of North American from returned migrants, who fed the yearning for an overseas life. During the war, a correspondent for The Maltese Journal drove around the islands, somehow managing to get lost until he stopped to ask a farmer for directions. To his great surprise, the farmer was a return migrant from Toronto, and his response to the journalist was in "such excellent English...you could have knocked me over with a feather.” The farmer, John Micallef, had gone to Canada in 1913 and ended up working in a packing house in Toronto while living on Clark Street. He returned to Malta in 1938 to get married and was trapped by the war. John later introduced the journalist to his brother Paul, who

\footnotetext{
${ }^{77}$ Frank Mifsud, interviewed by author, September 6, 2016, London, Ontario.
} 
also had gone to Toronto to grow vegetables but returned to Malta at the onset of the Depression in 1931. The entire scene caused a commotion and several other farmers came out to chat. Joe Saliba, another farmer, found himself in a similar situation to John Micallef, a returned emigrant from Canada in 1938 trapped by war. Joe landed in Canada in 1920 and worked around Weston in the Toronto suburbs. He left two brothers, Paul and Martin, as well as a godson who he believed was fighting in the Canadian Army. The journalist was floored. He made a final connection at the end of his article, noting that a Dr. V.M. Curmi, who lived in Valletta, had a relative in the Canadian Army as well. Writing to his Canadian and American audience back home, he ended the article by linking the connections between the Maltese communities there saying, "No. Malta isn't so far away..."78

Of course, the Maltese like many other men in the United States and Canada, joined the war efforts. Lawrence Muliett, who came over to Detroit in 1925 with his mother, joined the war at the outset serving and ultimately dying in the Pacific on Leyte Island in $1944 .{ }^{79}$ Both of Lawrence's brothers, and many other men also served for the American Armed Forces. In Canada, Anthony DeBatisse, one of the founders of the Maltese-Canadian Society of Toronto in 1921, served a distinguished career in the Canadian Army. A dairyman in Toronto before the war began, he enlisted on August 30, 1940 and left his wife Virginia and daughter Joan at home while he served overseas for six years and then continued in his Army position as a band member of the Royal Canadian Artillery and the Lincoln and Welland Regiment. ${ }^{80}$ Virginia herself pitched into the war effort as one of hundreds of Canadian women in Toronto to work in

78 The Maltese Journal, April 1944, Vol. 10, No. 4, 1.

${ }^{79}$ Interview with Rose Mifsud, June 1, 2016. Lawrence's sister, Rose, gave an interview and talked about her brother's service. A park in Corktown was later named after Lawrence's sacrifice. Muliett Park sits on Vermont Street and Marantette Street.

${ }^{80}$ MU 9783, F1405-89-14, MSR 5115, Ontario Provincial Archives, Toronto, Ontario. 
agriculture, eventually producing sixty-three million dozen eggs to be sent to Britain as war aid. ${ }^{81}$

In North America, the Maltese communities of Detroit and Toronto organized relief efforts for their beleaguered homeland. These efforts came primarily from the community clubs, benevolent societies, and the Catholic Church. One of the earliest events was the Grand Charity Ball thrown by the "Maltese Community of Detroit," on June 1, 1940 to raise funds for the British War Relief Societies. This vague "community" included organizations like the St. Vincent de Paul's Maltese Conference, the Sons of Malta, St. Mary's A.S.C., the Rambler's Benevolent Club, the Maltese-American Social Club, the Knights of Malta, and the Canadian Legion of the British Service League ${ }^{82}$ The event hosted at St. Andrew's Hall featured "Rose Marie Muscat, the five-year-old accordion marvel, Irene Mizzi, popular songstress of radio fame, Emanuel Fenech, wizard of the steel guitar, and Pearl Jacono, an accomplished accordion player," and was considered a massive success as the entertainers played in front of a sold out audience. ${ }^{83}$ The secular social organizations in Detroit played a major role in the raising of funds for the war effort, but they did not operate alone.

Leading the effort for the British War Relief Societies in Detroit was St. Paul's Maltese's own, Fr. Cefai. Throughout the war, Cefai organized several events, and while he was the spiritual leader of the community, the events crossed over from religious in nature to more inclusive of the entire community. One of the largest religious related events was a Mass for Maltese War Victims on November 24, 1940 at St. Paul's Maltese Church. The mass was

${ }^{81}$ MU 9783, F1405-89-14, MSR 5115, Ontario Provincial Archives, Toronto, Ontario.

${ }^{82}$ Maltese of City Work," Detroit Free Press, January 4, 1941.

${ }^{83}$ The general usage of "The Maltese Community of Detroit," gives the appearance of great unity within the Detroit region between the different Maltese organizations, including the Catholic Church. Important to note that Rev. Cefai was an important war time individual as a member of the British War Relief Society. The Maltese Journal, May 1940, Vol. 6, No. 5, 3; The Maltese Journal, June 1940, Vol. 6, No. 6, 3. 
elevated by the Archdiocese to a High Mass in honor of those Maltese seamen killed on the ships Royal Oak and Courageous, ships attempting to lift the siege of Malta. It was noted that the Knights of Malta Post 129, out of Windsor, along with Maltese Clubs of the city and the Parish Boy Scouts were "fully represented" at the mass. ${ }^{84}$ The Detroit Free Press noted in January of 1941 that a pledge drive, organized by the Church, encouraged the Maltese women's church groups like the Trinity Club to knit clothes and hospital accessories to send back to Malta. ${ }^{85}$

The war relief efforts in Detroit featured star power from outside the city limits as well. Joseph Calleia, a Maltese-born American Hollywood star became heavily involved with the Malta War Relief Fund. ${ }^{86}$ On February 8, 1941, Calleia visited Detroit, putting on a benefit dance and entertainment show to raise funds at the Mayfair Ballroom on Woodward Avenue. "Our Joe," as the Maltese Journal labelled him, entertained a crowd of two thousand five hundred Maltese for four hours. His visit to Detroit included personal visits to several admirers who had been ill, and featured Mr. Calleia as an auctioneer of "tangible and untangible" gifts at top price for charity, all while enjoying ravioli, pastizzi, and wine with the local community. ${ }^{87}$ The indomitable actor's visit was a large coup for the community. Calleia, as part of the USO tours overseas, became an incredibly popular and busy individual during the war years.

The Toronto community and the Detroit community cooperated closely in the fundraising efforts, including several visits to each city. A flier promoting one of the joint fundraising sessions exclaimed, "The Maltese of Toronto and the Maltese of Detroit Join Hands To Help

${ }^{84}$ The Maltese Journal, January 1940, Vol. 6, No. 1, 3.

${ }^{85}$ Maltese of City Work," Detroit Free Press, January 4, 1941.

${ }^{86}$ Joseph Calleia made a slight change to the spelling of his last name, replacing the " $\mathrm{j}$ " with an "I" in Calleja. Calleia reportedly did this to ease the English pronunciation. Calleia starred in 59 films during his career as well as several TV appearances. "Joseph Calleia - Malta's Hollywood Actor (1897-1975) - The Malta Independent," accessed April 12, 2017, http://www.independent.com.mt/articles/2013-05-21/arts-and-culture/joseph-calleiamaltas-hollywood-actor-18971975-1645477903/.

${ }^{87}$ The Maltese Journal, March 1941 Vol 7, No. 3, 2. 
'Malta' and its Civilian Population in Distress! ...God Bless America! Long Live the President of the USA! God Save the King!" 88 The second half of 1941 featured a visit in October from the Toronto Maltese Dramatic Club, Melita. This club prepared a new show and dance to entertain the crowd in Detroit and raise further funds for the War Relief Society. Their first show, on October 10, was warmly received by the Maltese Detroiters and their second show the next day was performed in front of the Mayor and his wife, Edward and Florence Jeffries, as well as a crowd of over five hundred for a second day. ${ }^{89}$ These dancers and entertainers from Toronto represented a growing, publicly organized social club that was spurred into greater organization and community development thanks to the war-time needs.

The Maltese Canadian Society of Toronto threw equally impressive solo fundraisers throughout the course of the war. The night after Calleia's big visit to Detroit, the community in Toronto threw a "Grand Get-Together" at St. Patrick's Hall. The get-together featured a "thrilling play by the Melita Dramatic Company under the direction of Mr. Chas E. Baldacchin." 90 The group in Toronto would not be outdone by Detroit's star power, bringing in their very own John Giordmaine, one of Canada's greatest magicians. Giordmaine began his life in Canada in 1919 having left, like many others of the era, the British dockyards in Valletta as a skilled tradesman, working as an electrician. However, an electrical accident at the Swift Packing Plant in Toronto caused him to rethink his career, taking up magic full time. He rose to great

88 "Maltese Catholics - Maltese Canadian Society of Toronto Publications, 1941-1997," OC21.MA02, Archdiocese of Toronto Archives, Toronto, Ontario. The flier also listed a wide range of locations to pick up tickets for the event including St. Paul's Maltese, Maltese American Social Club, Ramblers Benevolent Society, Sons of Malta St. Mary's ASC, Knights of Malta Post 129, Xerri and Xerri. Admission was 75C for adults and a quarter for children.

${ }^{89}$ The Maltese Journal, October 1941, Vol. 7, No. 10, 2.

90 "Maltese Catholics - Maltese Canadian Society of Toronto Publications, 1941-1997," OC21.MA02, Archdiocese of Toronto Archives, Toronto, Ontario. 
popularity across the nation. ${ }^{91}$ In 1943 the club publicly promoted itself as aiming to host social activities, dances, dramatic shows, picnics, entertainment, and a Christmas party for a membership fee of only $\$ 3$ per year. ${ }^{92}$ Not only did they send their Dramatic Club to Detroit for fundraising, but they continued to host events in Toronto itself for fundraising purposes. On February 2, 1944, Giordmaine returned to perform at St. Paul the Apostle in the Junction to a capacity audience. The Toronto Evening Telegram described the event as full of "miracles of mystifications, uncanny magic backed up with an overflowing gift of kindly humor." 93

The emergent Maltese Society of Toronto took a more active role in the raising of funds and community engagement for the relief of their beleaguered homeland. In a July 1943 report, the Society asked individuals for clean and used clothes to be donated as soon as possible. The report asked individuals to continue efforts to raise money throughout the city, having informed them that the knocking on neighbor's doors to raise a few dollars was "nothing in comparison to what they [people in Malta] are going through."${ }^{94}$ The Maltese community in Toronto achieved great success in fundraising, beyond just their neighborhoods. The same report confirmed that Loblaw, the Canadian Supermarket, donated \$1,500 to the relief efforts. In February of 1944, a report recapped the successful fundraising from the prior year, with Angelo Cutayar - President of M.C.S.T. and chairman of the Malta War Relief Fund of Canada - reporting a value of $\$ 100,500$ sent to Malta from Canada alone in 1943 . Not all of this was strictly cash, as the report

\footnotetext{
${ }^{91}$ John Giordmaine had an illustrious career in magic after leaving Swift Packing during the height of the Great Depression. He was fortunate to obtain work at Eaton's in Toronto in their toy department during the depression and hone his craft there. By the 1940s and 1950s he made several appearances on major television across North America including the Ed Sullivan Show in 1957. "Sleight of Hand," http://www.whitepinepictures.com/ seeds/iii/29/index.html.

${ }^{92}$ Meeting Minutes, 3 September 1942, Maltese Society of Toronto Fonds, MG 28 VII, Vol. 1, Library and Archives Canada, 1.

${ }^{93}$ The Maltese Journal, February 1944, Vol. 10, No. 2.

${ }^{94}$ Grace Borg, "Maltese Society of Toronto Memo," July 10, 1943, Archdiocese of Toronto Archives, Auxiliary Records - Second World War Fonds, SW RO Relief Operations, File 9, Item SW RO09.01.
} 
indicated \$50,000 worth of clothing shipped from the Toronto Evening Telegram alone. ${ }^{95}$ Still, the funds raised represent an astonishing sum considering the smallness of the community in Toronto.

As the war ended the communities of Toronto and Detroit began to think of them. Led by M.C.S.T., the prevailing view shifted to the care of those who had lost relatives in the war, and those who were gravely injured during the siege. In general, Angelo Cutayar pushed the Maltese community of Toronto to turn their post-war efforts towards the elimination of disease in Malta through the funding of improved hospitals and hospital equipment. ${ }^{96}$ In addition to caring for the sick, there was a great need to care for the dead. The concept floated by Cutayar was a "Mothers' Society" within Malta to honor the fallen Canadians. Cutayar proclaimed that nearly a quarter of all aircrew were Canadian and, "Canada's share in the defence of Malta, was great...Our Canadian airmen have written a golden page in the epic history of the siege of the Island." 97 The proposed organization would pair Maltese women who could care for the graves of Canadian dead in Malta with the mothers, wives, or daughters of the fallen Canadians. The program's success or failure is unknown, but it represented another connection between the Maltese community in Toronto and all Canadian people.

Back in Detroit, the end of the war tore away the last remaining shreds of unity within a community overloaded with organizations and leaders. The prevalence of Fr. Cefai during the pre- and post-war era earned him a reputation as of a community "lightning rod" and he quickly

\footnotetext{
${ }^{95}$ In total, \$24,000 of cash was donated from the Malta War Relief Fund, \$50,000 in clothing donations from Toronto Evening Telegram, \$25,000 from the Polish Veterans Association and \$1,500 from the Loblaw Aidto-Britain Fund. The Maltese Journal, February 1944, Vol. 10, No. 2.

${ }^{96}$ A.G. Cutayar, "The Malta War Relief Fund of Canada," Undated, Maltese Society of Toronto Fonds, MG 28 VII, Vol. 1, Library and Archives Canada, 1.

${ }^{97}$ A. G. Cutayar, "Malta War Relief Fund of Canada - Annual Report 1944", 5 March 1944, Maltese Society of Toronto Fonds, MG 28 VII, Vol. 1, Library and Archives Canada, 1.
} 
became the focus of much of the community's anger and frustrations. ${ }^{98}$ The funeral of Lawrence Muliett, a Maltese-American killed in action in the Pacific, highlighted this growing push away from Fr. Cefai's grasp. The Muliett family were among the Maltese who lived closer to Most Holy Trinity and attended that church more often than St. Paul's Maltese, which was on the other side of Corktown from their home. Rose Mifsud, Lawrence's only sister, recounted the preparation for the funeral saying, "They brought the body back, and my mother wanted him buried at Holy Trinity. He [Fr. Cefai] was very mad. My mother had wanted a High Mass for the funeral, and she wanted Father Borg, who was still living, as well the priest from St. Vincent's and Father Kern from Holy Trinity. That was what made Father Cefai very mad, very mad. She didn't back down though, she did what she wanted as she should." 99 The exclusion from the High Mass for the death of a Maltese-born, American soldier, and his replacement with the former spiritual leader of the community, Fr. Borg, illustrated the struggle Fr. Cefai faced in his quest to be the sole voice of the community. For his part, Fr. Borg - who lived in Detroit until his death - urged the Maltese not to be petty with rivalries and to come together regardless of community leadership. ${ }^{100}$

Ultimately, the ability to walk in two worlds, Malta and North America, was evident during this era. The Maltese communities of Detroit and Toronto not only struggled through Depression and then sacrificed men to the military duties of war, but also kept their native Malta close to their hearts and mind. In both cases, the Catholic Church played vital roles in the process providing a moderating mechanism both in Malta during the political crisis of the "Language Question" and abroad during the trials of the Great Depression and World War II. Embedded

\footnotetext{
98 Joe Mamo, interview by author, November 19, 2012, Farmington Hills, Michigan.

${ }^{99}$ Rose Mifsud, interview by author, November 19, 2012, Farmington Hills, Michigan.

${ }^{100}$ Attard, Profiles in Maltese Migration, 111.
} 
within the respective communities, it became part and parcel of the Toronto community working hand-in-hand to establish a strong, assimilated community, while in Detroit it became a competing force seeking to fence the Maltese community within its grasp. Despite being firmly established within the communities, the Church began to lose its prominence in Detroit. Instead, the influences of secularism and affluence in the United States, buying homes in the suburbs and in the lake country, turning to social organizations over the Church, pulled at the Maltese folk. All of these factors contributed to a deteriorating relationship with the Maltese parish. But at the end of the day, when the moment was most dire in the war years, the Church stood firm as a focal point of the Maltese community and the backbone of the financial support of their homeland. 


\section{Chapter 7 - Imperial Change in a Postwar Decade}

In the wake of the Second World War, power and economic influence shifted away from the Empires of old towards a new world dominated by the rising powers of the west, chiefly the United States, but also the British Dominions of Canada and Australia. For a small colony like Malta the shifting global diplomacy brought uncertainty. From 1945-1955, Malta stood in flux, receiving generous post-war grants from the Treasury in London to rebuild the heavily bombed island but facing an increasingly difficult emigration situation. One proposed solution, that was put to a vote in 1956, was a union with the United Kingdom, which included representation at Westminster. As the vote drew closer it transformed into a makeshift a vote for either independence or union. Simply remaining a colony no longer sufficed.

The post-war period brought with it change to Malta's economic, political, and social positions. The Malta that men and women left in the 1940s and 1950s faced much different challenges and opportunities than the Malta of the 1920s. This chapter aims to illustrate how Malta's shifting position within the Empire, and the growth of domestic political and social forces changed the emigration equation. It will do so by deliberating on Malta's precarious position within the world and the British Empire. For the first time, the impact of foreign immigration policies and Malta's best interests globally not only were debated within the halls of parliament but forced a considerable change in Malta's own political future. The immigration policies of the United States and of Canada both drastically reshaped the Maltese communities residing in those nations and brought forth a referendum on Malta's status within the Empire.

\section{Postwar Malta and its status within the Empire}

On the surface, the postwar years appeared to hold the same problem for Malta as existed in 1919, overpopulation combined with a plunge in the local economy with the drawdown of 
military expenditures. The resultant economic collapse demanded the emigration of thousands of Maltese, many of whom were trained in industrial skills, causing a significant brain drain on an already shaky economy. However, unlike the First World War, in which Malta was heavily involved but spared from conflict, the Second World War devastated the Maltese archipelago in both human lives lost and physical damage suffered. This massive destruction meant a boom in postwar construction work combined with a growing push for unionization that fought for a retention of highly skilled jobs in Malta. Formed in 1943, the General Workers Union fought for employment within Malta. ${ }^{1}$ Political currents in Malta drove the islands' leadership to seek financial aid from Britain coupled with quota increases on their traditional paths of emigration. Ultimately, the political limbo Malta sat in during the postwar years and the growing divide between labor and political elites greatly damaged any leverage they held regarding quota limits. More importantly, it forced many Maltese politicians to believe the only solution for a prosperous Malta lay in a more complete union with Great Britain.

On July 6, 1943, just weeks before the final bombs fell on the islands, the General Workers Union (GWU) mobilized for greater equality. Combined with many local benevolent societies, the GWU sent a list of long-standing demands to the British Government. Among the most important demand was a request to address the pay imbalance based on race. ${ }^{2}$ Refusing to give into worker demands with the war still raging, the Maltese broke into their first unofficial strike on August 24. The British made a new, although not much higher, wage offer in late September but workers rejected it, leading to another strike on September 28. Now, the flames of unionization in Malta were ablaze. On October 5, Reggie Miller, a clerk at the British Admiralty Dockyard, registered a small group of workers to officially form the General Workers Union. In

\footnotetext{
${ }^{1}$ Godfrey Baldacchino, Trade Unions in Malta, pg. 21.

${ }^{2}$ Ibid.
} 
the midst of the Sicilian campaign just to the north of Malta, the British government was in no mood to deal with Maltese labor unrest. In attempt to turn public opinion and quell the spark of activism, the British portrayed the Union as saboteurs. ${ }^{3}$ Despite this nationwide slander, the days after the formation of the GWU were marked with strikes and protests across the island at British military establishments. Having failed to extinguish union activism in Malta, the GWU grew in political power adding another voice to complicated and fragile political balance.

As the war ended, the GWU flexed its collective muscle in an attempt to save or create jobs for those employed by the war industry. In March 1946, the Union demanded that no worker was to be fired from work at the dockyards without a new job offer, and that efforts of reconstruction of the island's damaged infrastructure and buildings be sped up to offer construction jobs and get men out of temporary housing. The end goal of these demands was to avoid the prospect of postwar emigration. To strengthen their appeal, the Union reminded the government that economic hardship would make the Maltese sympathetic to Communism, a common threat of nationalist movements across European empires for leveraging a domestic agenda. ${ }^{4}$ A response came from the government ten months later. On January 24,1947 , the government launched the "Malta Reconstruction Bill and War Damage Fund" to finance the rebuilding of the Malta with an emphasis on education, sewage, and electricity. ${ }^{5}$ The demands from the Union and response by the government came at a time of not only great change internationally with the advent of the Cold War, but also for the Maltese economy.

In a cruel twist of fate, Malta lost two major avenues of employment in the postwar years - defense sector jobs and commercial dockyard work. At the end of the First World War, when

\footnotetext{
3 "History," General Workers Union Malta, 2017, http://www.gwu.org.mt/ReadText.php?ID1=L\&ID2=45.

${ }^{4}$ Attard, The Safety Valve, 16.

${ }^{5}$ Ibid.
} 
defense jobs disappeared some men eventually fell into work servicing long range civilian commerce at the dockyards. Unfortunately, in the 1940s, the war jobs dried up at the same time that Malta's once strategic position in the center of the Mediterranean slipped into irrelevance. The development of long range naval fleets meant that ships passed through the Mediterranean without requiring refueling, thus by-passing Malta altogether. ${ }^{6}$ This new development crippled the dockyards, the economic engine of Malta, which depended on commercial fleets during peacetime. The loss of commercial activity also simultaneously weakened the Union's position. The exodus of a substantial portion of the commercial fleets, coupled with the switch from war time into peace time, thrust the dockyards into economic ruin. The employment victory in the Reconstruction Bill was always a short-term solution. Eventually, Malta would be rebuilt and the construction jobs shifted elsewhere. It bought time for the Union, but shifts in international trade left the union without a secondary play. The resultant hardship led to a surge in demand for emigration. Faced with domestic economic devastation, the GWU settled for promises of training of emigrants before they left the islands.

By 1948, Malta's political parties, the Nationalists and Labor (the political arm of the GWU), agreed that encouraging emigration was necessary. ${ }^{7}$ Governmental migration meetings, held in the capital, Valletta, with both the Prime Minister and the Archbishop of Malta in attendance, worked with the Union to develop a solution for the rising unemployment. ${ }^{8}$ The Maltese government believed that within ten years 30,000 Maltese would be unemployed and

6 “Malta: Migration’s Microcosm,” International Migration Digest, Vol. 1 No. 2 (Autumn, 1964), 211.

${ }^{7}$ Malta's political parties underwent a period of shifts in the immediate postwar years with Labour dominating the elections. The Nationalist Party contested every election. It was a rotating third party however that consistently changed the nature of political debate. In 1947, it was the Democratic Action Party, a revival of the old Maltese Political Union party which sent forth Malta's first Prime Minister in 1921, Joseph Howard. By 1950, the third-party role had been re-established by Mabel Strickland's Constitutional Party, another revived party from the pre-war era. The Constitutional Party would contest elections throughout the early 1950s.

${ }^{8}$ Attard, The Safety Valve, 23-24. 
that the local industry could not expand fast enough to absorb both the growing population and the unemployed. The Emigration Department annual report in 1948 claimed that without immigration there would be "terrible consequences for the standard of living, the life and economy of the Islands." 9 Despite the GWU's immediate post-war hope of an economy able to employ the nation without mass emigration, the economic picture gradually began to erase those hopes and dreams.

Malta's main hemorrhaging of population was, much like the post-World War I era, skilled labor. These laborers, with little opportunity for employment in Malta at livable wages, looked to the United States, Canada, and Australia. With just a month to go before the October 1947 General Election in Malta, the Colonial Office began to wire to London, detailing the tremendous demand for emigration. Memos alleged that nearly four hundred skilled workers in the month of August alone left Malta for the United States, with some - though small in number - setting out for South Africa. British officials also highlighted the proposals given by the Labour Party, who they assumed would win the election. The proposals all focused on providing economic relief for the Maltese laborer and a greater integration between Maltese and United Kingdom industries. The specifics, including the "conversion of the Dockyard for civil production purposes...the production of UK products at some of the Maltese light industrial factories, ... and a Colonial Development Fund [to] help Malta set up new factories and industries." ${ }^{10}$ With a platform focused squarely on employment for all workers in Malta, the Labour Party led by Paul Boffa won the 1947 Malta general election.

\footnotetext{
${ }^{9}$ John Axisa, Report from the Department of Emigration for the Year 1948-1949, Malta, Department of Emigration, July 28, 1949, Bodleian Library - Oxford University, Oxford, England.

${ }^{10}$ T 220/79, “Overseas Settlement for ex-servicemen: Malta Scheme," September 1, 1947, The National Archives of the UK (TNA), Kew, England. Letter from A. Froude to E. Melville, Colonial Office. Proposals from the Labour Party included the conversion of the Dockyard for civil production purposes, so as not to witness 6,000 of 15,000 men go unemployed. The second was the production of UK products at some of the Maltese light
} 
The noble concepts of a reinvested and industrialized Malta failed to materialize. What emerged was a reluctant acceptance of emigration, but this time an even more prepared scheme for intending migrants. Having accepted that emigration was the only solution to Malta's postwar recession, the government invested heavily on skill training for those migrants who lacked professional ability. For men hoping to emigrate to the United States, Canada, or Australia, landing with a skill set gave the migrant a chance to join local unions and earn respectable wages. The success of the migrants who landed in Detroit with industrial labor experience confirmed its importance and the Labour Government looked to recreate that success for all migrants. Hoping to target high-demand fields of employment, Malta offered courses in plumbing, welding, electrical installation, woodwork, motor mechanics, radio mechanics, industrial chemistry, and lino-typing. In a single year, 1,000 men were trained and emigrated with 600 still in class and 400 on a waiting list. The classes provided by the government were not cheap; Malta spent $£ 48,586$ on migration in just a single year. Due to the expense, any migrant who returned to Malta within two years was required to repay the government in full. ${ }^{11}$

The GWU, and the Labour Government, continued to advocate to authorities in London for more equitable treatment towards Maltese within the Empire. By 1952, another wage dispute with the admiralty, primarily focused on the treatment and pay of native Maltese workers compared to those from England, created "ill-will and harm to...relations with the Island." 12 The disputed difference between the Admiralty's offer and the demands of the GWU, a grand total of $£ 47,000$ was deemed small enough that the UK government covered the amount in order to calm

\footnotetext{
industrial factories for export across the Med. - noting cheaper Maltese labor, and third a Colonial Development Fund which should help Malta set up new factories and industries

${ }^{11}$ John Axisa, Report from the Department of Emigration for the Year 1948-1949, Malta, Department of Emigration, July 28, 1949, Bodleian Library - Oxford University, Oxford, England.

${ }^{12}$ CO 926-36 "Notes from meeting with Mr. Deakin," August 1, 1952, The National Archives of the UK (TNA), Kew, England.
} 
the rising tensions. ${ }^{13}$ Sitting in Malta watching the labor dispute unfold, the American Consulate noted the mood of the country greatly improved as the dispute was being "deflated on both sides," with the Admiralty offering higher wages and the Union set to accept. ${ }^{14}$ More than a labor dispute, the rising tensions between the UK and Malta were part of a greater push for a conclusion of Malta's status within the Empire. The resolution of Maltese labor demands and its push for, though still unrealized, equality with English labor represented a small but crucial segment of Malta's self-status.

Issues of employment, wages, and identity were all tied to emigration. Greater numbers of migrants leaving Malta would decrease unemployment and steady falling wages. As postwar funds evaporated, the decision to pursue emigration surfaced as an alternative. Having decided that emigration was the only feasible option, a new problem emerged caused by diminishing destinations for Maltese laborers due to tightened global immigration policy. Thankfully for the Maltese, the path to Australia remained open and subsidized through series of intense but collegial negotiations. Despite the good will of exhibited by Australia, the continent continued to be a difficult place to get to due to a lack of available shipping for Maltese emigrants.

Furthermore, emigration to the United Kingdom, while completely open to Maltese individuals, was not enticing as a lack of plentiful, well-paying jobs greeted newcomers.

The emigration question once more was transformed by notions about Maltese racial profile. The sacrifices made by Maltese individuals and the civilian population during World War II earned the colony the George Cross, Britain's highest civilian honor. In the immediate postwar years, the Empire and indeed the world, looked favorably on Malta. This attitude opened

\footnotetext{
13 Ibid.

${ }^{14}$ Leslie Rood, "Situation in Malta - April 1952," 747B.00/4-1752 - RG 52, Records of the Department of State, NARA II, College Park, MD, 1.
} 
the possibility of solving the emigration problem that faced Malta as the prevailing global thought was that a people who withstood such atrocities were worthy and welcome migrants to any nation. The Australian Government expressed this favorable view, aimed primarily at Maltese ex-servicemen, in a memo to London asking "whether Maltese who have served 'with the British forces' would be entitled to free passage under the scheme for ex-service men...in view of their excellent part played by the Maltese in the defence of their Island they should be treated on all fours with other white British subjects for immigration purposes." ${ }^{15}$ The focus on Maltese ex-servicemen by the Australian government opened a most complex of identity issues within the Empire. This issue became hotly contested and a referendum on the standing of the entire Maltese population.

The classification of Maltese ex-servicemen in postwar schemes was used as a crutch in any political arguments on the status of Malta within the Empire. In 1943, the Overseas Settlement on Demobilisation, a scheme to provide free transport for ex-servicemen who were selected for immigration by the Dominions, was established. It was under this scheme that the Australian government approached London about the issue of Maltese ex-servicemen. The question raised brought with it "a number of points of some importance from the Colonial Office point of view." 16 The Colonial Office argued that the scheme should be limited as closely as possible only to service personnel from the United Kingdom but that a separate provision for Maltese service personnel should also be developed which would "inevitably mean a pro tanto increase in the amount of financial assistance to be provided for Malta by His Majesty's

${ }^{15}$ T 220/79, Overseas Settlement for ex-servicemen: Malta Scheme, "Emigration Scheme for ExServicemen Part 1 General," Defence and General Department, Colonial Office, S.W.1. November 24, 1944, The National Archives of the UK (TNA), Kew, England.

${ }^{16}$ T 220/79, Overseas Settlement for ex-servicemen: Malta Scheme, "Memo to Mrs. Bird - Colonial Office," November 28, 1944, The National Archives of the UK (TNA), Kew, England, pg. 1. 
Government." ${ }^{17}$ Exactly how that would be issued or if the Maltese would even be eligible remained a mystery.

The scheme's unclear language muddied the waters for the Maltese status. Due to the confusing categories of British personnel during World War II, particularly in terms of colonial troops, the scheme's terms, "forces of the United Kingdom" and "United Kingdom Services personnel," offered no clear delineation. ${ }^{18}$ The classifications of Maltese Army units provided further difficulty. While the King's Own Malta Regiment was very clearly a colonial and territorial unit, thus ineligible for certain benefits, the Royal Malta Artillery sat in ambiguity. Technically the force was a colonial unit, however it experienced combat as part of the United Kingdom, making its status tricky at best and incredibly difficult at worst. Furthermore, the issue of Malta's independence or self-government loomed. If Malta moved in that direction, the entire debate over the status of ex-servicemen was null and void as it would fall on the shoulders of the Maltese government to pay their passage. ${ }^{19}$ At the very least, the issue of Malta's status no longer rested on race or skin color. British officials made every effort to avoid racial distinction based on color and the Maltese were noted to be "now included' in the "white immigrant" status, a status that would in theory open doors to the Dominions who still sought to keep the Great White Walls standing. ${ }^{20}$

Ultimately, the resettlement scheme stalled in 1947 due to economics and logistics. Letters written in August of 1947 lament the dearth in available shipping available. Two years after the war ended only enough space existed on board ships to send a quarter of all migrants

${ }^{17}$ T 220/79, Overseas Settlement for ex-servicemen: Malta Scheme, "Memo to Mrs. Bird - Colonial Office," November 28, 1944, The National Archives of the UK (TNA), Kew, England, pg. 2.

18 T 220/79, Overseas Settlement for ex-servicemen: Malta Scheme, W. Russel Edmunds, "Memo to Miss M.L.S. Fisher - Colonial Office,” January 22, 1947, The National Archives of the UK (TNA), Kew, England, pg. 8.

19 Ibid., 9.

${ }^{20}$ Ibid., 2. 
from the United Kingdom alone. Preference was given to those demobilized Dominion forces headed for home. With this slowdown in international shipping, the Maltese were warned it could take at least three, maybe four, years to send the Maltese - who only consisted of 3,000 migrants - to their destined target of Australia under the servicemen scheme. ${ }^{21}$ The revelation on shipping, coupled with the realization by the GWU and the political parties in Malta that emigration would have to be pursued in the face of a lack of domestic employment only further stoked rising nationalist movements in Malta.

These rising tensions forced Maltese politicians to examine the treatment of exservicemen more closely. A memorandum on benefits for ex-servicemen released in 1947 stated that Maltese ex-servicemen were poorly treated both while in service and in their demobilization. The memorandum pushed for a greater amount of postwar care to the ex-servicemen in terms of assisted passage schemes as well as industrial training schemes, benefits which were given to the servicemen from the United Kingdom. The Maltese government, frustrated by a seeming lack of any progress, argued they should also be provided to Maltese ex-servicemen. The memorandum stated, "It is the view of Ministers that in appreciate of the war contribution made by Malta, the Maltese ex-servicemen should have extended to them by the Imperial Government some further benefits... Any pressure brought to bear for the holding of intensive courses of training in H.M. Dockyard would also be of great help."22 Beyond the intensive courses or aid-in immigration the "Rights and Privileges" section of the memorandum outlined that Maltese men - while receiving fairly equal, though still disadvantaged pay and benefits during the war, received almost no postwar benefits in comparison to their United Kingdom brethren. Programs like

\footnotetext{
${ }^{21}$ T220-79, Overseas Settlement for ex-servicemen: Malta Scheme, "E. Church letter to Colonel Edmonds," August 18, 1947, The National Archives of the UK (TNA), Kew, England, 2.

${ }^{22}$ T220-79, Overseas Settlement for ex-servicemen: Malta Scheme, "Memorandum: Benefits for exServicemen," December, 1949, The National Archives of the UK (TNA), Kew, England, 2.
} 
apprenticeships, vocational training, resettlement grants, and disabled persons rehabilitation were all denied. ${ }^{23}$

Despite the loud protests of Maltese and some Commonwealth officials, arguments for the equality of Maltese servicemen fell on deaf ears in London. A press notice on August 30, 1946 hailed the demobilization of Maltese servicemen as a great success. Attempting to create a positive view of the benefits given to ex-servicemen in Malta, the notice discussed the great numbers of employed men and women. With only 500 of 11,000 unemployed it stated, "the demobilization of thousands of troops might in itself have created mass unemployment and disturbance in industrial life. That danger has now been overcome."24 Given the knife's edge on which Malta's population rested between healthy employment and crisis level unemployment demanding emigration, hailing this success critically beat back Malta's demand for more Imperial funds. Painting the employment of Maltese ex-servicemen as a success was critical for the British as the Empire in the postwar world shifted. Under massive pressure, and split internally between decolonization and commonwealth, Britain began to worry about its ability to hold the Mediterranean. ${ }^{25}$

Beyond the employment of former servicemen, the British continued to push back against the idea that Maltese servicemen were treated poorly. After all, the Maltese for the most part were servicemen in Colonial units and not British Army units, which automatically denied them

\footnotetext{
23 Ibid.

${ }^{24}$ T220-79, Overseas Settlement for ex-servicemen: Malta Scheme, "Completion of Army Demobilization in Malta," August 30, 1946, Lieutenant-Governor's Office, Malta, The National Archives of the UK (TNA), Kew, England, 2.

${ }^{25}$ See; William Roger Louis, Ends of British Imperialism: The Scramble for Empire, Suez and Decolonization, (New York City: IB Tauros, 2006); The British Empire in the Middle East, 1945-1951: Arab Nationalism, the United States, and Postwar Imperialism (Oxford: Clarendon Press, 1984). Louis notes in the introduction to The British Empire in the Middle East the dire consequences facing Britain in the 1940s. Still facing rationing in Britain, and with American dominance growing globally, questions circled around British commitments overseas.
} 
certain benefits. The Maltese argument circled back to their status within the Empire. From a Maltese point of view, they were equal to a Dominion and certainly European. At the very least, they believed their benefits should have exceeded those of other colonial peoples from Africa or Asia. By 1948 however, British officials were increasingly agitated. A letter from Britain's Director of Labour and Social Welfare in Malta, H.E. Knott highlighted the differences between Maltese and British servicemen. Knott wrote that the Maltese officers were offered several options upon demobilization for employment or educational opportunities, while Maltese servicemen were given the opportunity to take courses in trades. But by the time demobilization came around there were civilian jobs that paid high wages - thanks to the need to rebuild Malta, and so many turned down the educational offers. ${ }^{26}$

Not only did the Maltese servicemen turn down education and employment training opportunities, most also had performed less taxing service than British soldiers. To Knott "The question of gratuities to Maltese ex-service men has been argued out time and again." He noted that, "it was open to any servicemen to volunteer to serve outside Malta. If he did, then he was attached to an English regiment and paid on the same scale as the English soldier - including gratuities, etc. The fact is that the Maltese did not want to leave Malta and therefore qualified only for gratuity appropriate to colonial troops serving in their own country." ${ }^{27}$ Furthermore, he continued for the most part Maltese servicemen had it easy after the invasion of Sicily, being given leave every weekend and the majority even sleeping in their own homes unlike the thousands of British soldiers who were far from home. ${ }^{28}$

\section{The Question of Integration}

${ }^{26}$ T220-79, Overseas Settlement for ex-servicemen: Malta Scheme, H.E. Knott, "Letter from Knottie [Knotts] to Oliver," September 28, 1948, The National Archives of the UK (TNA), Kew, England.

${ }^{27}$ Ibid.

${ }^{28}$ Ibid. 
The simmering tensions over workers' rights, rights of ex-servicemen, emigration, and Malta's status resulted in two critically important political fights. American Consulate Leslie L. Rood described these conflicts as "one is between the Left and the Right and the other is between the Maltese and the British." ${ }^{29}$ The acrimony fell on the issue of Malta's status, and ultimately on the issue of gaining the most leverage for emigration. From Rood's prospective, the Left (Malta Labour Party) sought to achieve full integration with the United Kingdom including up to three seats at Westminster. The Right (Malta's Nationalist Party) believed that only independence and/or Dominion status would elevate Malta. Both parties in Malta, however, sought greater financial security and a more respectable standing on the international stage. Rood pined the agitation directly back to the emigration problem and the lack of proper employment available in Malta. ${ }^{30}$

The second fight that Rood noted was a tussle over identity as Britishers and as Europeans. Dating back to the 1910s and 1920s, British political figures like Winston Churchill and Leo Amery often described Malta's position within the Empire as not only critical, but also natural as a European people. Amery went so far as to claim the islands' of Malta were not that different from the Channel Islands or the Isle of Man. ${ }^{31}$ The same issues resurfaced in the postwar years particularly in light of the islands new constitution which furthered the calls for complete integration with the United Kingdom. The 1947 Constitution, issued to fulfill a 1943

${ }^{29}$ Leslie L. Rood, "Political Situation in Malta," February 14, 1952.

${ }^{30} \mathrm{Ibid}$. On the topic of the political fight between left and right, Rood writes that the fight "has simmered quietly. This is because Malta's big current problems --- (a) approaching financial insolvency of the Government and (b) fizzling of the emigration drive --- go undiscussed by the major political factions." They went undiscussed to some extent - by the three most prominent of Maltese politicians, Prime Minister George Borg Oliver (Nationalist), Paul Boffa (Labour Party/Malta Workers' Party), and Dom Mintoff (Labour Party). It is fairly evident however that the fates of these national leaders depended on their ability to negotiate with the British government. Borg Oliver and the Nationalists lost the 1955 election to Mintoff and Labour due in part to their failure to acheive satisfactory results on their discussion of independence and Commonwealth status. Likewise, Mintoff and the Labour Party would resign in 1958 as plans for Malta's integration with the United Kingdom failed.

${ }^{31}$ See Chapter 2 on the discussion of Malta's political identity. 
promise to return Malta to self-government appeared to appease both Maltese and British political figures. The victory of Labour, and the re-emergence of Enrico Mizzi in the Nationalist Party who led the "Italian Question" campaign of the 1930s, pushed the Labour government decidedly pro-British. Even with this however, the 1947 left British politicians unhappy with how much legislative power they had surrendered and ultimately, the constitution failed to provide a stable and productive economy in Malta. ${ }^{32}$ This failure played a leading role in the road to integration. From London's point of view, Malta would never be a self-sufficient economic territory always relying on British aid. From Malta, the idea of integration meant access to funds in order to build an economy to achieve economic equality. Integration would be a clean slate and ultimately an easier governing status than the dyarchy that proved unwieldy in the 1940s and early 1950s. The calls for integration were unique within the Empire at the time because of how close the plan came to success. ${ }^{33}$

Despite decades of political discussion about Malta's proper status within the Empire, by the 1950s there existed no real conclusion. This failure to concretely define the islands' status, and the identity of the people on Malta, hindered the islands' development. Rood described the social conditions mentioning that "the English do not hide their personal feeling that the Maltese are a lazy, unreliable, overprolific people." ${ }^{34}$ Here Rood lays the blame at the feet of the British, writing critically that

Britain must bear some of the blame for the present uncertain position of Malta. Despite Britain's knowledge that because of the base she could never give Malta complete independence, she has failed to lay the groundwork for a satisfactory alternative such as, for example, inclusion of Malta within the United Kingdom.

\footnotetext{
${ }^{32}$ Simon C. Smith, British Documents on the End of Empire: Malta, Series B, Vol. II, London: TSO Publishing, 2006) Memo: CAB 134/52 C(47)1, Mr. Creech Jones for Cabinet Committee on Colonial Affairs, "Malta Constitution," January 6, 1947,pg. 4.

${ }^{33}$ Simon C. Smith, "Integration and Disintegration: The Attempted Incorporation of Malta into the United Kingdom in the 1950s," The Journal of Imperial and Commonwealth History 35, no. 1 (March 1, 2007 ): 66.

${ }^{34}$ Leslie L. Rood, "Political Situation in Malta," February 14, 1952.
} 
The high illiteracy rate and the low standard of living --- both things which Britain could have remedied in 150 years of rule --- as well as the differences in law and religion are hindrances to such a union. But instead of paving the way to some political status which would satisfy the Maltese, or any normal people, the British have left the islanders to ferment in their indefinite, inferior status. ${ }^{35}$

The "inferior" status of the Maltese demanded a resolution unlike any previous era in the Maltese-British relationship. Old attitudes of the Empire were challenged by a global shift in attitudes towards democracy.

While the British allowed the Maltese to ferment in their status, Maltese politicians in the postwar era openly challenged their colonial position. Led by Prime Minister Borg Oliver, Maltese politicians attempted to influence the perception of their island nation through public displays. Pursuing the Nationalists' policy of independence and commonwealth status, Borg Oliver played hardball at the Coronation of Queen Elizabeth. At first, he outright refused to attend unless he was seated with the Prime Ministers of Commonwealth nations. It was only under the influence of Sir Winston Churchill that a special arrangement was designed to appease the Maltese delegation. Instead of riding with the Commonwealth Prime Ministers, Borg Oliver rode instead with Lord Brookebrorough, the Prime Minister of Northern Ireland. The offer signified at the very least Malta's elevated status compared to other colonial territories, and Borg Oliver finally accepted and attended the Coronation. However, grumbling over the move persisted in London as reports from the United States Embassy in London suggested "junior officials in the Colonial Office termed the Maltese action as "sheer blackmail."'36

\footnotetext{
${ }^{35}$ Ibid. Rood's attack on the British dealings in Malta was prefaced by his critique of their imperial attitude, stating, "Though Britain is not threatened in her tight little fortress of Malta with a loss of control such as has occurred in Iran or Egypt, she displays in Malta the same inability to unbend from her former position of grandeur which has exacerbated her latter-day structural weaknesses in 'colonial' countries. Examples: when a foreign admiral visits Malta the British Navy refuses to a schedule a call on the Prime Minister though it schedules calls on half a dozen British officials; the Colonial Office, though it is half of the responsible government, does not give frequent explanations of its position in disputed matters, but instead maintains a discreet silence about everything."

36 "The Colonial Office says that this proposal is designed to meet the simmering Maltese nationalism which has been at a relatively high peak ever since the Coronation (Embassy dispatch 185 July 9). It will be recalled
} 
The Nationalist push for independence and commonwealth status rested on ideals and outcomes that would be difficult to obtain. From a British point of view, the transfer from the Colonial Office to the Commonwealth Relations Office was not only improbable but additionally that office had no desire to receive Malta. The Nationalist government in Malta continued to suggest this was their ultimate destination, despite the signs that it was not the appropriate venue. At the very least this insistence forced officials to make some concessions over the protests of Oliver Lyttelton, Secretary of State for the Colonies, who argued that Malta had neither sufficient size nor financial and economic independence to achieve Dominion status. ${ }^{37}$ Before those concessions were made however, there had to be an understanding of what drove this nationalist uprising in Malta. The analysis of the situation was that the "Maltese labor under several delusions. ${ }^{\prime 38}$ Of these delusions, the first was that the Colonial Office was responsible for Malta's lack of economic assistance. The failure had nothing to do with the Colonial Office, but rather the Treasury. The Treasury Department would be the most vocal critic of Malta's integration plan, noting that the United Kingdom could never expect taxes from the island to even come close to balancing the services offered, stating that integration was simply a blank check for Malta to cash. The second delusion revolved around their European status, something

that the Maltese Prime Minister at first refused to come to the Coronation unless he could ride with the Prime Ministers of the Commonwealth rather than representatives of the Colonial Territories. At the intervention of Sir Winston Churchill, a special arrangement was made which would permit Dr. Borg Oliver to ride with Lord Brookeborough, the Prime Minister of Northern Ireland, in the Coronation procession." Margaret Joy Tibbetts, Second Secretary of Embassy, approved by J.K. Penfield, Counselor of US Embassy, "Future of Malta," December 15, 1953. 747B.00/12r1553, RG 52, Records of the Department of State, NARA II, College Park, MD, 1-2.

The director of Emigration John Axisa wrote that "The mission showed that there was a wealth of goodwill and co-operation in the receiving countries towards our people which we had failed adequately to appreciate. It is in our interest to cultivate by all means, particularly by personal contacts, the closest relations with the other members of the Commonwealth and the U.S.A. not only to maintain our legitimate place within the Commonwealth but as a necessary condition for the promotion of migration." His insistence that Malta was already part of the Commonwealth is an interesting note and an early sign of the Nationalist Party's goal to achieve Commonwealth status through repeated association. Axisa, Report from the Department of Emigration for the Year 1948-1949, 2.

37 Simon C. Smith, "Integration and Disintegration: The Attempted Incorporation of Malta into the United Kingdom in the 1950s," The Journal of Imperial and Commonwealth History 35, no. 1 (March 1, 2007 ): 54.

38 Tibbetts, "Future of Malta," December 15, 1953. 
the Maltese believed was denied to them by their status as a colony. Finally, the transfer to a more "sympathetic" office would bring a greater amount of prestige to Malta. ${ }^{39}$

To both appease Malta and finally solve the troublesome Malta problem, the British Government proposed integration through a transfer to the Home Office. This move theoretically solved the delusions so suffered by the Nationalist Party in Malta, and at the same time addressed the entire nationalist movement on the islands. The prospective move to the Home Office put Malta on the same level as the Isle of Man and the Channel Islands, who were all part of the United Kingdom defense system. This was critical as troubles in Egypt and Cyprus moved Malta from a critical link in the imperial defense to the front line on the Mediterranean. ${ }^{40}$ Beyond defense, the proposed integration answered not just Malta's nationalist trend but also solved the troublesome and unwieldy dyarchy that had ruled in Malta since the 1920s. Even more important than the unification of Malta with the United Kingdom was the change in international posture as far as race and status was concerned. Bringing the Maltese people into a European fold once and for all, as well as closer to the status of truly British citizens. ${ }^{41}$ Floating under these concerns remained the issue of emigration. Without a doubt, this major issue was left

\footnotetext{
${ }^{39}$ Ibid.

${ }^{40}$ Simon C. Smith, "Integration and Disintegration: The Attempted Incorporation of Malta into the United Kingdom in the 1950s," The Journal of Imperial and Commonwealth History 35, no. 1 (March 1, 2007): 49-71

41 "Since the Coronation questions of precedence have been of first concern to the Maltese and their request for transfer to the Commonwealth Relations Office was in accord with these nationalist stirrings....According to the Colonial Office, the Maltese labor under several delusions concerning the advantage of a transfer: (1) that the Colonial Office is responsible for their continued failure to receive all the economic assistance which they desire, (actually, it is the Treasury which constantly blocks their requests); (2) that by being under the Colonial Office improper recognition is taken of the fact that they are really a European people; (3) that all these questions of precedence and prestige would be solved by being transferred to a more "sympathetic" British Government Department, - 'little do they know,' is the Colonial Office comment on this aspect of the Maltese thinking. All in all, the Maltese are tired of being under the Colonial Office and think that they could do better elsewhere. In fact, their request to go to the Commonwealth Relations Office was quite impracticable, apart from the fact that that Office wanted nothing to do with them...It did seem advisable, however, to attempt to meet their aspirations in some manner and transfer to the Home Office would make the necessary provision for the defense relationships inasmuch as the other islands under the Home Office, such as the Isle of Man or the Channel Islands, are integrated with the defense of the United Kingdom. In addition, transfer to the Home Office might appear in some manner to recognize the 'European' nature of their way of life as well as bringing them slightly closer, as far as appearances are concerned, to the British Crown." Tibbetts, "Future of Malta," 15 December 1953.
} 
off the listed "delusions" because it continued to be a problem that both governments acknowledged without reservation. Full integration and the move to the Home Office would have opened immigration avenues and potentially solved the problems of emigration for Malta.

Like earlier movements of the GWU and the issue of ex-servicemen, the integration scheme lost steam at a critical moment. Despite Mintoff and the Labour Party's victory in Malta's 1955 election and his mandate to pursue integration, by 1958 the two sides no longer saw a feasible direction forward. Mintoff's demands for complete economic equality for Maltese, particularly in terms of social services, throttled the integration talks. British ministers, like Labour MP Richard Crossman, argued that the Maltese did not want to be British, but rather had no other option for the full rights of citizenship within the Empire except for integration. His voice, expressing the binary choices facing the Maltese, was joined by James Griffiths, former Secretary of State for the Colonies, who added that a failure to integrate Malta would only leave Malta with the option of complete independence from Britain. ${ }^{42}$ By early 1958, as the two sides sat down for talks on integration, it was clear that Mintoff would not - or could not - back down on his insistence for economic equality. Buoyed by the GWU and the labor classes of Malta who sought to raise the economic profile of the island to prevent emigration, Mintoff's hardline position eventually resulted in large scale disorder in April 1958. On April 29, after days of demonstrations, Governor Laycock declared a state of emergency and direct rule followed for three years in Malta. ${ }^{43}$ With integration dead, Malta steamed ahead towards eventual independence.

The convoluted political mess that engulfed Malta during the late 1940s and early 1950s not only lead eventually to independence but also kept Maltese migrants from achieving their

\footnotetext{
${ }^{42}$ Smith, "Integration and Disintegration" The Journal of Imperial and Commonwealth History, 59.

43 Ibid., 65.
} 
ultimate aims. As both the British and Maltese governments wrestled with the question of where exactly the Maltese fit into the scheme of Empire, it ultimately damaged the ability of politicians to push issues of emigration. With political capital spent on the difficult negotiations of imperial status, Maltese and British officials failed to return to a post-World War I situation where they jointly and properly leveraged the Maltese British status to pry open doors of migration. For the Maltese communities in North America, these political debates mattered greatly. While the debates shaped the future of Malta, it similarly shaped the future and shape of the communities in Detroit and Toronto. 


\section{Chapter 8 - The Struggles of Post-War Communities}

When the Maltese in Malta went to the polls to choose their destiny in the 1950s, their choices directly affected their compatriots across the diaspora. The unsettled domestic and political issues in Malta directly impacted Maltese abilities to migrate particularly to North America. Through the program of ex-servicemen benefits and assisted passages, the door to Australia was open wider than to any other country in the postwar years. Despite this, Australia was a reluctant destination at first. In the immediate postwar years, Maltese emigrants still preferred the cities of the United States and to a lesser extent Canada. This preference was only natural as the great success of Maltese emigration to the United States in the 1920s created a large community with deep ties, and a small but similarly successful community in Canada, drawing their extended families to join them in the later years. The failure to form a large community in Australia prior to the Second World War meant a much-reduced desire to initially take the free passage. Yet, the struggles both politically and logistically to reach North America after the war slowly eroded Maltese desires to make such a journey.

Furthermore, both the United States and Canada in the post-war period experienced rapid growth. For the Maltese living in Detroit and Toronto, they witnessed this growth first hand. Detroit underwent the changes accompanied with suburbanization that dominated American cities in the 1940s, 1950s, and 1960s. Those Maltese living in the city took part in the "white flight" from the urban core to the leafy suburbs. Those in Toronto witnessed something very different, the growth of the urban center forcing people to move to the outer fringes of the city for cheaper land and cheaper homes while the core of the city welcomed Canada's largest banks, businesses, and cultural centers. This chapter attempts to blend both the difficulties of post-war emigration and the community building in these changing cities of North America. How the 
Maltese communities dealt with these forces was found in part in their communities founding and in part how reimagined their organizations, be it religious or secular, to face their shifting environments.

\section{A Changing North America}

While Malta worked to renegotiate its standing within the Empire, and Britain dealt with the issues of decolonization, the nations of North America enjoyed a postwar boom. In both Canada and the United States, economies grew at a rapid pace. Both the United States and Canada escaped the war with no physical damage, and while the postwar economies experienced momentary hiccups switching from war footing to peacetime industries, by the late 1940s and early 1950s North America was abuzz. Growing numbers of trade deals between the two meant a shared prosperity. ${ }^{1}$ Beyond simple economic growth, both nations worked ever closer in the emerging Cold War. The emerging "middle rank status" Canada had earned shifted from a sphere of influence more entwined with Britain to one much closer to the United States. It was the government led by William Mackenzie King that convinced Americans to join NATO, and in turn the Canadians joined the Americans in the Korean War. By the 1950s, the North American Aerospace Defense Command (NORAD) was formed, merging the air defense of the two nations to better protect the continent. ${ }^{2}$ In almost every way the two nations became further aligned.

Detroit, the industrial darling of the United States, should have exploded in the postwar boom. Yet it did not. The postwar world saw a shift in both the industrial capacity and the population of the city. While the metropolitan area of Detroit as a whole retained a vast majority of the auto industry, the city of Detroit lost its prominence as jobs began to move to the suburbs

\footnotetext{
${ }^{1}$ Franca Iacovetta, Gatekeepers: Reshaping Immigrant Lives in Cold War Canada (Toronto: Between the Lines, 2006), 17. Iacovetta particularly points to the Marshall Plan and the arms race as driving both economies.

2 Ibid.
} 
and by the late 1950's they moved out of the state completely in order to avoid the high cost of unionized labor. In 1950 Michigan had 56\% of all auto industry related employment but by 1960 that percentage dropped to just $40 \% .^{3}$ The deindustrialization of the city occurred in tandem with the changing composition of the city's neighborhoods. By the late 1920's and early 1930's the ethnic neighborhoods of Detroit began to slowly collapse, and by the 1940's neighborhoods were more often defined by class and race as whiteness became more important than ethnicity. This conflict came as the city's black population began to move into Corktown, competing for low cost housing with Detroit's ethnic Catholic population. These neighborhoods were traditionally built around the presence of a large, vibrant Catholic parish, and the Maltese were no different, as their communities were built around St. Paul's and Most Holy Trinity in Corktown. ${ }^{4}$ In response to this demographic shift the Maltese population began to move to outlying areas of the city, and to Dearborn, in $1948 .^{5}$

As people left Corktown, city officials in the fifties began to fear its imminent collapse. In response, city officials developed a renewal plan to clear a seventy-five-acre site to develop warehouses and small businesses. The West Side Industrial Project was met with staunch opposition from neighborhood church leaders and ethnic clubs from the ethnically heterogeneous neighborhoods that remained. They believed the project would be destructive for the community. But the project was billed as a failure not because it destroyed the intricate fabric of the neighborhood, cutting city blocks in half, disrupting the flow of streets but because of its lack of pace. The West Side Industrial project took ten years to develop, displaced families, and due to its slow speed of construction was unable to stop any exodus of industry from the area and

\footnotetext{
${ }^{3}$ Thomas J. Sugrue, The Origins of the Urban Crisis: Race and Inequality in Post-War Detroit (Princeton, NJ: Princeton University Press, 1996), 128-129.

${ }^{4}$ Ibid., 22, 241.

5 “Malta Provides Detroit with Big, Efficient Colony," Detroit Free Press, August 8, 1948.
} 
therefore provided few jobs. ${ }^{6}$ The final nail in the coffin for the ethnic communities of Corktown was the construction of the John C. Lodge Expressway. The expressway not only tore through the heart of the community, but also destroyed St. Paul's Maltese Church as part of the Urban renewal programs which were intended to increase the accessibility to the city. ${ }^{7}$ Despite the best intentions of the federal renewal programs, home prices plummeted in Corktown and people gave up on the ethnic neighborhoods of Detroit. ${ }^{8}$

Just to the north and east of Detroit, Toronto boomed. ${ }^{9}$ The postwar growth in Toronto was shocking and in some regards unexpected. The city, always an important Canadian city and provincial capital was - in many ways - very similar to Detroit throughout the early 1900s, if not still under the shadow of Detroit economic might until World War II. The postwar years however witnessed the great divergence along the historical path between Detroit and Toronto. The latter transformed from an industrial town into the financial and business capital of all of Canada. Toronto became home for all of Canada's "Big Five," the largest five banks in the nation. Not only did financial institutions and companies open new branches in Toronto, but also they were expanding so rapidly that they drove the growth of the city. Filling those jobs were hundreds of thousands of migrants. Toronto attracted the bulk of immigration in the postwar nation. Some 713,315 Toronto residents were foreign born -43 per cent of its population - by $1971 .{ }^{10}$ For

\footnotetext{
${ }^{6}$ Sugrue, The Origins of the Urban Crisis, 165.

${ }^{7}$ Carl Abbott, Urban America in the Modern Age, 1920 to Present (Arlington Heights, Ill: Harlan Davidson, 1987), 87.

${ }^{8}$ Sugrue, The Origins of the Urban Crisis, 242.

${ }^{9}$ The two cities are separated only by 230 miles and today one can make the trip up Highway 401 in under four hours. The connection between the two cities thrives along this road. Heavy amounts of truck traffic moves auto parts between the factories of Michigan and Ontario, making the freeway one of the heaviest trafficked in North America. Relating directly to this story, many Maltese migrants in the late 1960s and 1970s would fly into Toronto and be picked up by relatives from the airport and driven to Detroit.

${ }^{10}$ Iacovetta, Gatekeepers, 7. Iacovetta writes that not only did Toronto attract migrants, but within the entire metro area of more than two million people, $36 \%$ were foreign born in 1971. "Half of Canada's newcomers had come to Ontario, with 727,011 Europeans representing almost 60 per cent of this total."
} 
immigrants, the comparisons between Toronto and the war-torn world of Europe were striking. Manufacturing grew and expanded, financial sectors moved to the city and exploded in growth shifting Canada's economic center from Montreal to Toronto. It was immigration that fueled that rise. $^{11}$

\section{Post-War Emigration}

The immediate postwar years witnessed a low tide of emigration. The blunted appetite to emigrate, fueled by reconstruction jobs, however, existed as only a mirage. Recently unemployed Maltese men desperately sought avenues for emigration. In 1948, the Department of Emigration reported that 30,000 boys would reach working age within ten years and an additional 10,000 would be laid off from the reconstruction work. At the rate of only 1,000 new jobs created a year, the Department calculated that without mass emigration nearly 120,000 people, or a third of Malta, would go unprovided for within the decade. ${ }^{12}$ However, few paths for mass emigration existed at the time. While an emigration scheme between the Governments of Malta and Australia had been concluded, a lack of shipping available to take Maltese emigrants meant a delay in their departures. Furthermore, though the United States remained technically open to full Maltese migration, that path was slowed by no other reason than a lack of a consular official in Malta to issue visas. Hopeful migrants had to travel to Tunis to secure their immigration visas, adding additional expenses many migrants could not afford. The vacant American post was not filled until $1949 .{ }^{13}$

\footnotetext{
${ }^{11}$ Franca Iacovetta, Such Hardworking People: Italian Immigrants in Postwar Toronto, (Montreal: McGillQueen's University Press, 2014), xxii.

${ }^{12}$ John Axisa, Report from the Department of Emigration for the Year 1948-1949, Malta, Department of Emigration, July 28, 1949, Bodleian Library - Oxford University, Oxford, England, 3.

${ }^{13}$ Ibid.
} 
Attempts to find solutions were haphazard at best. After negotiation, London convinced the Canadian government to take a one-time quota of 500 Maltese settlers in 1947-1948. Those settlers, in contrast to the first Maltese migration of the 1920s to Canada, made excellent impressions on Canadians. The Department of Immigration voluntarily agreed for an additional 250 Maltese men to come to Canada in the following year. ${ }^{14}$ Canadian generosity ended with those two temporary quotas. John Axisa, Minister of Emigration and Labour in Malta, called those quotas a simply gesture of war thanks, and without lasting effect as Canada's doors remained closed in general. Axisa wrote in 1951 that "with the passing of time this goodwill towards Malta has gradually died down and today we are no better to Australia and Canada than their wartime enemies." ${ }^{15}$ A war gesture or not, the one-time quota provided some relief by establishing a more recent network of anchors for intending emigrants. By sending men first to fill the temporary quotas, and allowing them to become established, it relieved pressure by allowing families to later join them in Canada.

From 1945 until 1951, emigration proceeded despite difficulty until after 1949 to the United States. Several thousands of Maltese men and women flooded into the country, making the United States one of the largest receiving nations in the postwar era. Taking advantage of the nearly unlimited quota assigned to the United Kingdom, many of those who came to the United States though did so paying their own way. ${ }^{16}$ By 1949, the Emigration Department in Malta reported that the "most successful form of migration is that whereby the migrant goes forward

\footnotetext{
${ }^{14}$ Humphrey Mitchell, "Letter to J.J. Cole, Minister of Immigration and Labour, Malta," 5 August 1949, Immigration: Maltese Nationals, I-50-12. Library and Archives Canada.

15 OPM 326-1951, Office of the Prime Minister, National Archive of Malta (NAM), Rabat, Malta.

${ }^{16}$ In the Emigration Report of 1955, the report mentions that the Maltese leaving for the United States before the McCarran Act of 1952 had access to the nearly unlimited quota of the United Kingdom. Amato Gauci, Report on the Department of Emigration for the Year 1955, Malta, Department of Emigration, September 7, 1956, Bodleian Library - Oxford University, Oxford, England, 6.
} 
independently at the call of relatives or friends. ${ }^{17}$ Seven hundred and twenty-three migrants overcame the hurdles of transit and lack of consular officials in Malta in 1947-1948 to make it to the United States, the second largest total behind only the United Kingdom. ${ }^{18}$ But as the hardships in Malta lessened ever so slightly by 1952 there was a perceptible shift in migration destinations as migrants preferred to go to Australia or Canada on reduced fares rather than paying full fare prices to travel to the United States. ${ }^{19}$

For those who did travel to America, the trip was not necessarily easy. John Grima, a former medic in the British Army, went to Detroit in 1947 ahead of his family. While his trip was rather easy, his wife and daughter were one of these families that first travelled to Tunis to obtain their visa, adding expense and time to their trip. ${ }^{20}$ Others, like Mary Busuttil ran into quota problems highlighting the still precarious position the Maltese found themselves. Busuttil's husband, a Maltese national serving in the British Navy had passed away. Despite her husband's British status and having lived in Malta for thirty years, her visa reverted to the Greek quota, her nation of origin. Her situation was made all the more tragic as she had no family left in Malta and her sons lived in the United States already. ${ }^{21}$ The case of Mary Busuttil lends credence to comments made by the Director of Emigration John Axisa that a bad feeling about the prospects of emigration persisted on the island in 1949 and beyond. ${ }^{22}$

\footnotetext{
17 John Axisa, Report from the Department of Emigration for the Year 1948-1949, Malta, Department of Emigration, July 28, 1949, Bodleian Library - Oxford University, Oxford, England, 3.

18 Ibid.

19 "There is enough hardship in Malta to induce people to leave for Australia at nominal fares on Government subsidized ships, but no ships can be found. But there is not enough hardship in Malta to induce people to leave for America on the many ships charging standard fares. Most sensible people on the island recognize that the compulsion of unemployment is needed, but this is, of course, not a thing which a political figure can state publicly." Leslie L. Rood, "Political Situation in Malta," Malta to the Department of State, February 14, 1952 , 747B.00/2-1452, RG-52, Records of the Department of State, NARA II, College Park, MD, 1.

${ }^{20}$ Mary Grima, John Grima II [son], Rose Grima-Cataldi [daughter] interview, interviewed by author, May 29, 2016, Chesterfield, Michigan.

${ }^{21}$ OPM 170-1950, Office of the Prime Minister, National Archives of Malta (NAM), Rabat, Malta.

${ }^{22}$ By 1952 however, Maltese begin to fly in some cases for emigration helping to ease the backlog of migrants. "Presume you see no objection to such arrangement to transport emigrants by air in view of scarcity
} 
The passage of the Walter McCarran Act of 1952 added to those grim feelings around the idea of emigration to the United States. Although there was great protest against the Act, both by officials in Malta and people of Maltese descent in the United States, the reality suggested that these efforts were put towards a population less inclined to migrate to the United States by the early 1950s. With a continually growing population, the Government of Malta embarked on a plan to both push emigration with subsidized travel to Australia or Canada and provide full employment for those who remained in Malta. But the push for full employment, and poor attitudes towards migration, meant few people desired to emigrate. ${ }^{23}$ Despite that fact and the change of migration direction, the thought of America's doors being shut to the Maltese precipitated political maneuvers in Malta. On one hand, hope for an integrated Malta would open access to the entirety of the United Kingdom quota, guaranteeing that the Maltese would always have a safe harbor for excess population. ${ }^{24}$ On the other hand, some explored the American military's use of Malta as a base.

shipping." Axisa, Report from the Department of Emigration for the Year 1948-1949, 3; CO 926-34 "Sir Gerald Creasy to Secretary of State for the Colonies," January 2, 1952, The National Archives of the UK (TNA), Kew, England.

23 “The first quarter of 1952 has made it plain that Malta's efforts to hold down her population are failing. The natural increase of the population continued at its amazing rate and there was only a trickle of emigrants to balance the increase. Even more serious than the lack of departures was the fact that there are few people on the island now desirous of departing. The backlog of people who could not go during the War has now been used up, and with full employment at fairly good wages on the island there is little incentive to leave. For the past year the common belief in Malta has been that it was impossible to obtain shipping space for the many emigrants who wanted to go. Actually, the only difficulty has been in finding low-priced ships and now it is becoming apparent that even if the passage to Australia were free there would not be many takers. In summary, through lack of political courage the Government is pursuing a policy of full employment which has the double effect of pushing it toward insolvency and defeating its own emigration drive. Leslie Rood, "Situation in Malta - April 1952," Foreign Service Despatch, April 17, 1952, 747B.00/4-1752, RG 52, Records of the Department of State, NARA II, College Park, MD, 2.

${ }^{24}$ The US Consul in Malta wired to the Secretary of State in Washington the following, "If Maltese decide accept British offer of transfer to home office it is likely they will try to get British firm support in pressing United States to put Malta, as part of home office, under British mother country quota." Paul Paddock, "Incoming Telegram: Department of State," Malta to the Secretary of State, May 26, 1954, 747B.00/5-2654, RG 52, Records of the Department of State, NARA II, College Park, MD; Similar sentiments are expressed in British documents, CO 926-34, "Minutes of the Minister of State on the Visit of Mr. Cole from Malta," August 26, 1953, The National Archives of the UK (TNA), Kew, England, 1; 
The stationing of a unit of American airmen and a naval squadron in Malta became a political football. Maltese government officials believed they had a right to demand some form of payment from foreign powers using their land for military purposes. ${ }^{25}$ The dyarchical government, however, stated that it was the Governor, and ultimately London, who decided issues of defense. In this instance, defense included American forces. The issue, over which the Maltese self-government had little control given the British controlled defense measures, created tensions. To calm the situation, Britain through Admiral Mountbatten bent to the will of local politicians Borg Oliver and Mintoff, which by only increased their aggressive nature in negotiations. The Maltese never intended that the United States pay cash. Instead, they looked for concessions. The payment Borg Oliver and Mintoff ultimately sought from the Americans was an increased quota in exchange. ${ }^{26}$ In 1953, it appeared that Borg Oliver and Mintoff would actually get their wish as President Eisenhower apparently considered an amendment to the Act in light of the stationing of U.S. troops in Malta. ${ }^{27}$

Attitudes soon changed, however, throughout 1954 the American Consular Official, Paul Paddock wrote several reports on the Maltese immigration situation. Paddock wrote in May that political pressure by the Maltese government was constant in both public functions and in the press over the issue of American military bases in Malta. But Paddock replied in private to his superiors in the United States, that Canada and Australia offer nearly unlimited emigration opportunities. He added that the Maltese "believe better life exists in the US and many have relatives in US," but that this "would seem insufficient basis to alter US Immigration policy, as

\footnotetext{
${ }^{25}$ And to some extent one could see how the Government of Malta attempted to leverage their prime military position against the British to extract more in terms of services and money from London with constant threats of independence and upheaval.

${ }^{26}$ Paul Paddock, "Current Political Situation in Malta," Foreign Service Despatch, October 28, 1954, 747B.00/10-2854, RG 52, Records of the Department of State, NARA II, College Park, MD, 12.

${ }^{27}$ CO 926-34, "Minutes of the Minister of State on the Visit of Mr. Cole from Malta," August 26, 1953, The National Archives of the UK (TNA), Kew, England, 1;
} 
formulated McCarran Act, in behalf [of] Malta." ${ }^{28}$ Paddock later wrote in October that the average Maltese know only two things about the United States, something about their relatives in Detroit or New York and that the quota was cut to 100, which many of them resented. ${ }^{29}$ Paddock's report chided the Maltese for the demands in increased quota numbers, noting that, "an American finds it difficult to see why the quota system should be altered for the benefit of those Maltese emigrants unable or fearful of settling in those two pleasant and booming countries." ${ }^{30}$

While American officials in Malta rejected the idea of a special amendment for the Maltese, politicians within the United States made several pushes for just that. Unlike the earlier migrations of the 1920s, the Maltese community by the 1950s had sufficient size to help influence immigration policy, or at the very least make their voices known. Representative Martha W. Griffiths (D-Michigan), congresswoman from Michigan's $17^{\text {th }}$ district, which included Detroit's Corktown neighborhoods, moved for an amendment to the Act in May of 1956. Her bill, H.R. 784, stated that "people born in Malta be allowed access to the United Kingdom immigration quota." ${ }^{31}$ Other movements which followed the same line were led by members of the Catholic Church. Edmund Cummings, a member of the National Catholic Welfare Conference from New York, claimed that 5,677 people in Malta had registered to immigrate to the United States and were being denied due to the visa restrictions. ${ }^{32}$

${ }^{28}$ Paul Paddock, "Incoming Telegram: Department of State," May 26, 1954.

${ }^{29}$ Paddock notes that the building of a new power plant by the Americans under the ECA at a cost of $\$ 2,000,000$ went completely unrecognized by any political leader or news in Malta. Instead, Maltese politicians took credit for the plan, and the British governor would not admit that Great Britain needed American help to build the plant. "There was no gratitude among the Maltese or the British official or the British military for the $\$ 2,000,000$ that built it. Fortunately, that was not the basic reason why ECA projects were inaugurated." Paul Paddock, "American Consul Current Political Situation in Malta" October 28, 1954, 9.

${ }^{30}$ Ibid., 11.

${ }^{31}$ Attard, The Safety Valve, 43.

${ }^{32}$ Ibid. 
Representative Katharine St. George (R-New York), a Lady Grand Cross of the Sovereign Order of St. John, or the Knights of Malta, introduced Bill H.R. 1171, which was nearly identical to Rep. Griffith's H.R. 784, which again attempted to give the Maltese access to unused British quota. ${ }^{33}$ Despite the work of these advocates, neither of the bills were passed and, unlike the 1920 's, the Maltese were unable to access the unused British visas. There is no doubt that the Maltese push for integration within Britain, and its ultimate failure occurring at the same time as these legislative pushes in the United States, made Malta's status unclear, keeping legislatures from making any definitive plans. Until Malta and Britain came to an agreement on her status within the Empire, no change in American policy was forthcoming.

Emigration to Canada on the other hand was a different, although not always better, situation. While it was noted on several occasions that no restrictions or quotas existed against the Maltese entering Canada in the postwar years, immigrants needed to have a close relative sponsor them in order to gain entrance to the country. In contrast to the World War I era, Canada now needed skilled laborers to help power its postwar economic boom. ${ }^{34}$ Even with those light restrictions, Maltese emigration to Canada accelerated in the 1940s and 1950s. Malta sent nearly five thousand migrants between 1946 and 1953, reaching a peak in 1951 with 1,607 individuals entering Canada. ${ }^{35}$ Then in 1952 emigration to the Dominion diminished as a new ministry - the Ministry of Citizenship and Immigration - took over for the Ministry of Labour in Canada. This change tweaked immigration policy and led to a more restrictive attitude. J.J. Cole, Malta's

33 Ibid.

${ }^{34}$ Constantine looks at changing demographics within the Anglo-world in the postwar years noting that Britain itself began to compete with Canada, Australia, and New Zealand in attracting "those with skills and capital, need by industry, commerce and the professions - personnel, in other words, which British society could least afford to lose. No longer was the British Empire-Commonwealth so much a harmonious economic system, featuring a core British economy and a dependent periphery. Instead, there was competition between some of the parts." Stephen Constantine, "British emigration to the empire-commonwealth since 1880: From overseas settlement to Diaspora?" The Journal of Imperial Commonwealth History, Volume 31, Issue 2, 2003, 26.

35 Axisa, Report on Emigration from Malta during 1951-1953, 3. 
Minister for Emigration \& Labour wrote in 1953 that "the present Canadian Minister of Immigration having insisted that all Maltese immigrants should be skilled men, whereas the Minister of Labour in Canada had previously been willing to accept ordinary artisans." ${ }^{36}$ This change resulted in a slight slow-down of Maltese migration, dropping from its peak in 1951 to just under seven hundred in 1952, or less than half the previous year's numbers. ${ }^{37}$

The hurdles of skilled trades, family anchors, and changing Ministries were accompanied by the continual flux of Malta's position within the Empire. Cole noted that Malta's ambiguous constitutional status caused Canadians to hesitate on any immigration plans. Until Malta's status was solidified within the Empire, the admission of Maltese migrants on equal footing with emigrants from the United Kingdom or other white Dominions could set a difficult precedent. He added that "it had fallen through because it was felt that if Maltese were admitted in this way other inhabitants of Colonial territories would demand the same right" and that position would change should Malta move to the Home Office. ${ }^{38}$ Joseph Borg, hoping to migrate to Canada, wrote the Governor of Malta on this issue in April of 1951. Mr. Borg argued that he wished to emigrate to Canada, to pay a full passage without government assistance, and that "In my opinion, I am entitled to enter into a British territory being a British citizen with a clean conduct. ${ }^{39}$ Shortly after writing his letter, Borg left for the United Kingdom, failed to get a ship to Australia and consequently went to the United States where he was promptly deported. Maltese authorities in December officially declined his request to go to Canada, stating they considered it "too dangerous to let him go to Canada" after being asked to tighten up the

\footnotetext{
${ }^{36}$ CO 926-34, "Minutes of the Minister of State on the Visit of Mr. Cole from Malta," August 26, 1953, 1.

${ }^{37}$ Gauci, Report on the Department of Emigration for the Year 1955, 3.

${ }^{38}$ CO 926-34, "Minutes of the Minister of State on the Visit of Mr. Cole from Malta," August 26, 1953, 1

${ }^{39}$ OPM 326-1951, Office of the Prime Minister, National Archive of Malta (NAM).
} 
selection of migrants. ${ }^{40}$ Even with the technically unlimited quota, Maltese were still cautious and in some cases disadvantaged in going to Canada.

The quota system, effective in the United States in late 1952, and the shift from Ministry of Labour to Ministry of Citizenship and Immigration in Canada in 1952 slashed on the numbers of Maltese migrants to North America. The restrictions on Maltese emigration into the United States was devastating. The flood of immigrants that wished to settle in the United States was cut to a trickle of just 100 new visas per year. In 1954 nearly 5,000 people were denied entry into the United States from Malta, with a good deal of those destined for Detroit. ${ }^{41}$ In Canada, the mass immigration in the late 1940s and early 1950s gave new life to the small communities of Maltese in Toronto and to some extent Windsor. It even spawned new communities like that in London, Ontario. The slight tightening of immigration regulations in Canada post-1952 still offered a more generous position than that of the United States, and the smaller community of MalteseCanadians grew alongside the booming city of Toronto. In Detroit, however, the heyday of that community - much like the city it called home - rapidly came to an end, destined for decades of decline and struggle.

\section{Changes within the Maltese Communities}

Much like their respective cities, the two Maltese communities followed an increasingly divergent path. While a similar number of migrants went to both Detroit and Toronto in the postwar years, the large size of the Detroit community and the rapid pace of suburbanization meant those new migrants failed to reinvigorate the community. Meanwhile those migrants that made it to Toronto impacted the community in a much more lasting manner. Those new migrants

\footnotetext{
${ }^{40}$ Ibid.

${ }^{41}$ Attard, The Safety Valve, ch 3, sec. 3.
} 
stayed close to one another in the Junction, developed deep bonds of community, and grew the Maltese presence in the city.

Especially noteworthy were the divergent fates of the Maltese Catholic parishes in Detroit and Toronto. The community in Detroit, much like the city they called home, began to crumble in the postwar years. Part of the reason for this dissolution of the community was its own success. The growth of the community and its successes in the 1920s and 1930s diminished the insularity of Detroit's Maltese. Increasingly, they followed other whites who fled the city for jobs in the suburbs, after World War II. This action scattered the community in the urban landscape. Despite these changes, it should be noted that the white flight of many established Maltese was slowly replaced by the new trickle of Maltese who came to the United States and often first settled into the city itself, usually Corktown. Some of those individuals were able to give a small burst to the urban community and remained even as the best jobs moved to the suburbs.

Similar to the 1920 s migration patterns, it was often men who came first and alone to Detroit in the 1940s before sending for their family. John Grima, a former a medic in the British Army during the war, went to Detroit in 1948 hoping to find work. Well-educated and English speaking, Grima found work in the city as a maintenance man at Hudson's, Detroit's iconic shopping center. To make ends meet, he picked up a second job as a taxi driver. His wife, Mary, begged him to quit when she arrived in 1949 because he had been robbed on several occasions. To help off-set the loss of income, Mary took in laundry and shoveled coal part-time. ${ }^{42}$ John Sultana's father also emigrated to Detroit in the postwar years, working at Ford Motor Company before sending for his family in 1951. Joe Mamo was another who came to the city of Detroit in

\footnotetext{
${ }^{42}$ Mary Grima, John Grima II [son], Rose Grima-Cataldi [daughter] interview, May 29, 2016.
} 
1950. His path was similar to John Grima's, working first at Hudson's as a busboy before finding more career oriented employment working at Ford as a foreman. For Mamo, he recalled that jobs were plentiful and easy to obtain. He took a bus on his first day in Detroit to Hudson's and was employed three days later. ${ }^{43}$ These men represented steady anchors for their families and a pathway into the United States, even under difficult situations that presented themselves in reaching for the Maltese.

Even though immigration proved to be a somewhat difficult endeavor to the United States in the post-war year, the urge to migrate brought thousands of Maltese to Detroit. As Joe Mamo recalled, "the quota just slowed [emigration] down, it didn’t stop it." ${ }^{44}$ Mary Grima brought her brother and her young children, Rose and Bill, to Detroit in 1949 after travelling to Tunis to secure their visas. For others like the Sultana's, the journey was difficult for a variety of different reasons. Though Mary Grima could only speak some English, she understood enough to function. John Sultana recalled that his mother knew no English upon coming to the United States. Adding to that difficulty was the trip itself. They crossed the Atlantic in heavy storms. Once they reached New York City, his mother - unable to speak English - could not figure out what train they needed. Eventually, someone stopped to help them find a train to Detroit. When they arrived, John handed a piece of paper with a phone number on it to someone so they could call their father in the city to come pick them up from the station. ${ }^{45}$

Some of the migrants who joined the Detroit community did not come directly from Malta, but through Canada. The ability to live in Windsor and be within close proximity to friends and family in Detroit attracted hundreds of Maltese to the city. Charles DeMarco went to

\footnotetext{
${ }^{43}$ Joe Mamo interview, interviewed by author, November 19, 2012, Farmington Hills, Michigan.

${ }^{44}$ Ibid.

${ }^{45}$ John Sultana interview, interviewed by author, March 9, 2014, Detroit, Michigan.
} 
Canada in 1948 as part of a group of Maltese laborers invited by the Government of Canada. He initially landed in Halifax and was told to proceed to Vancouver. But, with an Aunt and Uncle in Detroit, he instead went to Windsor where he found a job at a Ford plant. Being near his family was a tremendous benefit. Even with work, he found himself often with little extra money each month and subsequently at his Aunt and Uncle's home in Detroit on the weekends for food and entertainment. After a mandated two years in Canada, his family sponsored his visa to the United States, pledging $\$ 68,000$ to secure the visa. In 1950 , DeMarco moved to Detroit and was able to pick up work at Ford, this time in the Detroit. After his visa was secured, he left Detroit for Malta to secure a wife. News had travelled to Detroit that his former girlfriend was engaged to another man, and Charles decided it was time to act. He left for Malta, found his former girlfriend, Gelarda, and proposed to her in front of her then fiancé. Gelarda gave the ring back to the other man and wed Charles in Malta. They returned to Detroit in 1952 where Charles found work immediately back at Ford. ${ }^{46}$

The Maltese who moved to Detroit in the postwar years had even better job success than their counterparts in the 1920s. Stories like that of Charles DeMarco showed how easily men with skills or previous industrial experience could gain work at the various auto plants of Detroit. DeMarco, a trim line worker in Windsor was able to find the same work in Detroit. He worked with a number of other Maltese on the same line. ${ }^{47}$ John Grima eventually worked his way into the Ford family as well, working at the Ford Foundry until his retirement. ${ }^{48}$ And then there was Joe Mamo who bounced around jobs before he finally found a place at Master Pneumatic on the East Side of Detroit and eventually a becoming a production supervisor on the line at Ford. Even

\footnotetext{
${ }^{46}$ Charles DeMarco interview, interviewed by author, March 9, 2014, Detroit, Michigan.

${ }^{47}$ Ibid.

${ }^{48}$ Mary Grima, John Grima II [son], Rose Grima-Cataldi [daughter] interview, May 29, 2016.
} 
the American born Maltese men like Junior Muliett, a mechanic who worked in the wind tunnels, found regular employment with Ford. ${ }^{49}$

One of the reasons Maltese men were so successful in the auto factories was due to their reputations for a strong work ethic. Diane DeMarco recalled an Irish manager at Ford confiding in her that he always sought Maltese men to hire as they were "dependable and hardworking laborers. ${ }^{, 50}$ As part of the management team, Joe Mamo confirmed that reputation. He stated that the concept at the time was, "if you were a good worker then you would recruit another good worker." In much the same way as migration operated in a chain fashion, so did employment at Ford, as Maltese men in positions like Mamo’s hired other Maltese men. What made the hiring particularly easy, he recalled, was that so many of them, almost two-thirds, worked in the shipyards. In the 1950 s they possessed better industrial traits than many other immigrants. They were millwrights, pipe fitters, shipyard workers, and had some level of English language ability. Joe's whole family worked for Ford, his three brothers and his father, two of the brothers even worked at the same plant. ${ }^{51}$

This new migratory wave of Maltese not only secured work quickly but joined a rapidly assimilating ethnic community. The successes of integrating into American culture remained a point of community pride. Father Cefai remarked in a letter to the Archbishop,

These people passed and will continue to pass their Naturalization Examination for U.S. Citizenship very easily. The Maltese range highest in percentage of Naturalized citizens among the foreign groups. I was always proud of my people when I used to work with Louis Miriani and Judge Tuttle as a member of the

\footnotetext{
${ }^{49}$ Junior was the brother of Rose Mifsud, and their father was Emmanuel Muliett who was featured in early chapters. Emmanuel worked for Chrysler as an electrician and both Emmanuel and Junior were union men. Rose Mifsud interview, interviewed by author, November 19, 2012, Farmington Hills, Michigan.

${ }^{50}$ One of Diane's longtime friends from school was the son of the Irish manager, and while sitting with both of them one day in the past few years, the father told her about the story of preferring to hire Maltese men. Diane DeMarco Markavich interview, interviewed by author, March 9, 2014, Detroit, Michigan.

${ }^{51}$ Joe Mamo interview, November 19, 2012.
} 
Americanization Committee, and I did help thousands of Maltese Immigrants preparing their cases for Naturalization or as a witness. ${ }^{52}$

Not only did Maltese men achieve high success rates in their workplaces and citizenship tests, but some even began to run for political office. In 1954, one of the first Maltese to run for office was William R. Parnis of Detroit who ran for State Representative. Parnis, an American-born Maltese, graduated from University of Detroit in Political Science in 1952. Two years later, he received 15,000 votes in his effort to join the state legislature. ${ }^{53}$

With these new migrants blending with the established migrants, the social and sporting clubs continued to be strong representatives of their communities. Charles DeMarco immediately joined the Maltese soccer club sponsored by the Maltese American Benevolent Society when he arrived in Windsor in 1948. The club looked up, literally, to other ethnic teams like the Hungarians and Italians, but played far better than their short stature. DeMarco recalled beating nearly all the ethnic clubs in the city, as most of the Maltese players had been semi-professional players back in Malta. ${ }^{54}$ Joining the soccer club helped DeMarco and many other migrants

${ }^{52}$ In a rambling letter about the need for more Maltese priests in the community to preach to Maltese men and women in their native language, Fr. Cefai wrote "The Archdiocese does not need it, neither do the spiritual needs of the Maltese in this diocese require it. For language is no problem with the Maltese in their spiritual life neither. Ninety-eight and a half per cent of our Maltese in Michigan speak English very well and absolutely want and insist to be registered members of those American parishes in whose territory they reside and own their home. Thousands of our married people are American born and speak no Maltese. Thousands of our young people are also American born: they speak only English. The immense numbers of our children born in Detroit or Michigan do not speak Maltese and hate to hear it even when both their parents came from Malta. Are these English speaking people of Maltese descent to be ministered to in Maltese? We cannot even classify them as Maltese. No, they say, I am not a Maltese: my father is, or my mother was, but I am an American. Moreover, almost all of our Maltese Immigrants, who came to America these last 40 or 35 years, speak English grammatically well: They learned it in school -

Malta's school kept going underground even during the great blitz...In factories, in department stores, in hospitals, in schools, in banks, in offices, in government departments and in all kinds of utilities companies and industries, where they are employed and esteemed, our Maltese Immigrants, men and women alike, do not meet and deal with Maltese bosses and co-workers, they do not speak Maltese, but English; they take orders giving in English to them, and they do their work admirably well. There is no American parish today in Detroit and its suburbs that has not a good number of Maltese." Michael Cefai, "Letter to Auxiliary Bishop and Chancellor of Detroit, the Most Reverend John A. Donovan,” St. Paul Parish, 1-4 Correspondence 1941-1958, Archdiocese of Detroit Archives, 3 January 1958, 3-4.

${ }^{53}$ Malta News: Ahbarijiet Ta'Malta, July 1954, p. 1. Library and Archives Canada, Ottawa, Ontario.

${ }^{54}$ Charles DeMarco interview, March 9, 2014. 
assimilate to the community, allowing them to meet other people within the social clubs as well as provide some familiar relaxation in their new city.

The Club, both soccer and social, kept in close contact with their counterparts in Toronto. DeMarco was part of the team featured in a cross-community soccer series in August 1954 between the Detroit team and the team representing Malta United of Toronto. The spectacle drew "almost all the Maltese Canadians from all parts of Toronto...[and] quite a few Maltese Americans from Detroit accompanied their team as well." 55 The game at Earlscourt Park went in favor of the Detroiters, 1-0, much to the dismay of a disgruntled, but graciously conceding Carmel Sapiano, who wrote the column from Toronto. The Toronto team travelled to Detroit on September $5^{\text {th }}$ for the Labor Day weekend to play at Robinson Field. The Toronto team this time exacted revenge in a big way, winning 9-4. ${ }^{56}$ At the conclusion of the game, both Toronto and Detroit Maltese were "entertained at the Maltese-American Benevolent Society Club." 57 These types of cross-border interactions grew as both communities in Detroit and across Ontario witnessed new immigration.

With a rapidly growing Maltese population in Windsor, the international boundary became more porous and less defined. Not only did Maltese have family members living on both sides of the border, much like they always had, but the proliferation of personal radios and ease of transit across the border meant that access to both sides of the border and a connection with each nation became easier than ever before. Mary Grima was one of those who lived in the region and enjoyed the ease of movement across the border. She recalled going to Windsor to get groceries on several occasions and meet with friends she knew in Windsor for coffee. Mary

\footnotetext{
${ }^{55}$ Carmel Sapiano, “Around the West-End Toronto," Malta News: Ahbarijiet Ta'Malta, September 1954, Library and Archives Canada, Ottawa, Ontario, 2-3.

${ }^{56}$ Malta News: Ahbarijiet Ta'Malta, September 1954, Library and Archives Canada, Ottawa, Ontario, 4.

${ }^{57}$ Malta News: Ahbarijiet Ta 'Malta, October 1954, Library and Archives Canada, Ottawa, Ontario, 4.
} 
enjoyed her time in Windsor, shopping with friends, having coffee, and buying groceries. She laughed recalling that walking home in the winter, she slipped, fell, and broke all two dozen eggs she had just bought. However, the trip was one she continued to make with frequency. ${ }^{58}$ Mary Grima was not the only Maltese to mingle across the border. The ever-popular Maltese excursion to Bob-lo Island, the amusement park on an island in the Detroit River, reemerged in the postwar years. Bob-lo Island required Americans to "cross the border" as it lay on the Canadian side of the river, but that never halted many people from either side of the border from enjoying the park together. ${ }^{59}$

Bridging the international divide even more was George Bonavia. Bonavia represented one of the most classic examples of Maltese living in North America during the 1940s and 1950s. He was an individual certainly at home in several nations. Despite his ardent nationalism for his new home, Canada, he certainly felt and responded to needs and wishes of the Maltese community in Detroit. ${ }^{60}$ His ability to bridge the permeable border between Detroit and Windsor - and thus between Michigan and Ontario, earned him great professional advancement. He

${ }^{58}$ While her English “didn’t match with this, the English over here [in North America]," she knew a little bit from her time in Liverpool and living in the British Quarters in Malta. Her first venture into Canada happened completely by chance. One day shed decided to go downtown and see if she could figure out how to get to Windsor. Once she arrived at City Hall she asked a woman waiting for a bus, "Excuse me, I'm looking for something and I don't how how to get there, I want to go to Canada!" The lady told her to take the bus under the tunnel and pointed across the river saying, that Canada was just over there. Mary Grima, John Grima II [son], Rose Grima-Cataldi [daughter] interview, May 29, 2016.

${ }^{59}$ A "Diary for August" in the newspaper lists August 21 as the "Maltese Excursion to Bob-Lo." The Boblo Boat was well known in the Detroit region and people recall found memories of boarding it in Detroit or Windsor and taking it to the island. The meeting the community on Bob-Lo often bore fruit, allowing young Maltese men and women to mingle. These interactions on several occasions led to marriage and a further cross-boundary entanglement. Debbie Muliett, a Maltese-American daughter of immigrants, and Victor Calleja, a new migrant to Windsor, met at a Bob-Lo picnic in the 1970s and eventually married with Debbie moving to Canada. This type of cross-border marriages was common in the Detroit-Windsor Maltese community. Malta News: Ahbarijiet Ta'Malta, August 1954, Library and Archives Canada, Ottawa, Ontario, 2.

${ }^{60}$ This comes directly from his newspaper which argued "The concept of togetherness is highlighted in the very patriotic and pro-North American newspaper, Malta News." "The community of interest of Canada and the U.S.A. on the grand scale - economic, political, strategic - can readily be underlined by the activities of citizens of both countries who are, literally, neighbours and friends." Malta News: Ahbarijiet Ta'Malta, July 1954, Library and Archives Canada, Ottawa, Ontario, 3. 
landed in Canada in 1948, and worked four years on the assembly line at Ford in Windsor. He then found work as an insurance underwriter for Mutual of Omaha until he began work for the Department of National Revenue as Customs and Excise Officer in Windsor starting in 1954. During all of this time, he continued to be a correspondent for the Allied Malta Newspapers and a member of Ghaqda tal-Kittieba tal-Malti, the Association of Maltese Writers. ${ }^{61}$ But he did more than that; he published his first book, Canada, Land of Hope and Prosperity, in 1951 and followed that with "three more books of similar nature." He began printing his newspaper, The Malta News, in 1954 and broadcast on CBC each Thursday night at 7 o'clock a radio show called International Rendezvous. The show had such popularity that it was broadcast both in Windsor, where it originated, and Toronto. In effect, Bonavia touched the Maltese communities in Detroit and Toronto through media.

Despite all the good deeds, Bonavia - at least to Fr. Cefai - represented all that was wrong and falling apart with the Maltese community. To the longtime Maltese priest, the center of his folks' attention should be held by the church and not social clubs or secular organizations. Cefai complained vigorously that despite giving Bonavia financial help - of which no record exists - that he always attacked Cefai and the Church. The most unfortunate outcome of this aggression was the ruining of a "young and ambitious Father Vella" who was sent to Windsor to preach to the Maltese. ${ }^{62}$ Bonavia, however, "claimed they did not need a Maltese parish or pastor...for they spoke and understood English.." ${ }^{93}$ So instead of attending church where Vella heard confession and preached mass, the Maltese of Windsor attended Canadian English Ontario, 1-3.

61 “George Bonavia Bio,” July 14, 1961 MG 31, H 31, No. 1836, Library and Archives Canada, Ottawa,

${ }^{62}$ Michael Cefai, "Letter to Auxiliary Bishop and Chancellor of Detroit, the Most Reverend John A. Donovan," St. Paul Parish, 1-4 Correspondence 1941-1958, Archdiocese of Detroit Archives, 3 January 1958 , p. 1. 63 Ibid. 
parishes. This neglect of Fr. Vella left him penniless and forced him back to Malta, "discouraged and broken-hearted." ${ }^{64}$ The problems for Fr. Cefai in Detroit though were much larger than a man, however important, in Windsor.

One of the many problems for the Maltese in the 1940s and 1950s became housing. For new migrants, the situation was difficult and it often required jumping from apartment to apartment before finding a place to settle. In the Grimas case, John's small apartment did not allow children, and when his wife and children first arrived in Detroit he took them there by blindfold, bringing them up the back alley so his wife would not see the conditions of squalor. After two days, the Grimas were discovered and evicted. Luckily, with help from the St. Boniface Church community and Fr. Cefai, they quickly found a two-bedroom flat in Corktown. The Sultanas also had a similar nomadic experience. John Sultana recalled staying in their first apartment on Labrosse and Trumball St. in Corktown for only a few years' period before moving to the northwest part of the city on Grand River and Livernois. After seven years in the city, they too left for the suburbs. ${ }^{65}$ The Grimas would eventually flee to the suburbs as well. Their stately home on Maybury Grand, which Mary whole-heartedly adored had purchased after saving $\$ 2,000$, was taken by the city of Detroit and demolished to make way for Interstate $96 .{ }^{66}$

64 Ibid.

65 John Sultana interview, March 9, 2014.

${ }^{66}$ Mary's love for the home was immense. She recalled seeing the home every day as she took her kids to the park. After lengthy negotiation with the owner of the house, it turned out the home was to be for sale soon and he was going to sell it for $\$ 10,000$. John, now working at the Ford Foundry, had to regrettably tell his wife that the home was too expensive. She shocked her husband by producing the $\$ 2,000$ necessary for the down payment. She said they were "without a penny again, but when I saw that house, I went bananas! It was worth every penny of it." The Grima's were able to split the home into two apartments, both with three bedrooms and two bathrooms. They went from renters to home owners and eventually landlords within a short span. Their most memorable renters were a Japanese family, Roy and Marleen Sztsuda. The Sztsuda family came to Detroit after the war. They had been put into internment camps during the conflict and stripped of all their possessions and Roy's business in California. Eventually, with a loan from Mary who was able to scrap together another $\$ 2,000$, Roy launched a new business venture in Detroit. It was a wise investment by the Grima's. With a new business venture the Sztsuda's were able to repay the loan and their rent on time every month, speeding up the Grima's payment on their mortgage. Mary Grima, John Grima II [son], Rose Grima-Cataldi [daughter] interview, May 29, 2016. 
The problems of housing were rolled into the problems of the city. Despite the new Maltese families slowly populating Corktown, many Maltese families were leaving the neighborhood. Almost all of this movement was due to the city's urban renewal plan from building new interstates to industrial projects. Arguing against a second Maltese priest in Detroit, Fr. Cefai wrote the Archbishop stating, "The Corktown Maltese will soon have to surrender their homesteads to the City. Many of them are eagerly awaiting to be paid the City condemnation money for their homes so that they could move to the northwestern sections of town and to the suburbs. They all tell me so." ${ }^{97}$ Fr. Cefai was not the only one to report on the exodus. The Malta News wrote in a column about the plight of individuals living in what would become the West Side Industrial Project, as some - along with their neighbors - attempted to fight for their property. "The Corktown Home Owners Organization, led by a Miss Ethel Claes as President and incorporated in March 1951 called for a hearing with City Council in order to let the Council know "we expect practical ways of improving our property instead of being chased around." 68 Sadly, many were "chased around" and the actions of the Home Owners Organization were largely futile.

Problems outside of housing worsened for the Maltese in Detroit as the decade progressed. For the established Maltese community, pre-war struggles transformed into post-war divides. Though Fr. Cefai worked tirelessly to promote the wellbeing of the Maltese community and the benefit of Malta during the war, his actions also drew intense criticism. By 1946, the Maltese community began writing to have Fr. Cefai replaced, much like they did to Fr. Borg in the 1920s. Several letters to the Archdiocese explained that when he arrived 18 years ago, the

\footnotetext{
${ }^{67}$ Michael Cefai, "Letter to Auxiliary Bishop and Chancellor of Detroit, the Most Reverend John A. Donovan," St. Paul Parish, 1-4 Correspondence 1941-1958, Archdiocese of Detroit Archives, 3 January 1958 , p. 6.

${ }^{68}$ Correspondent, "Maltese Property in Detroit Considered for Condemnation," Malta News: Ahbarijiet Ta'Malta, August 1954, Library and Archives Canada, Ottawa, Ontario, 1.
} 
religious services were all very well attended, but since that point, almost no one attends services at the Maltese church "due to his tactics and unethical actions."69

For a large handful, Fr. Cefai represented in full the crumbling of the community. The venerable priest was seen basically begging his community to donate for a new church building and this search for more money brought many into bitter contention with Fr. Cefai. A letter written on December 20, 1947 by Emanuel Scibberras told a very different story of the Maltese community than the ones Cefai wrote. Scibberras mentioned that the incoming Maltese priests in Detroit were very necessary because so many of the new immigrants spoke little English, contrary to Cefai's argument that no new priest was needed because "Ninety-eight and a half per cent of our Maltese in Michigan speak English very well." ${ }^{, 70}$ Regardless of the need for a new priest, or the English capability, Scibberras continued to argue that the "Maltese Colony is disintegrating very rapidly" mostly due to Fr. Cefai who "pretends to be the leader of the Maltese Colony in Detroit [when] In effect, he is nothing but a "money changer."'71

Some of the loudest criticisms against Fr. Cefai and the Church revolved around the spending of community money. Another letter written in anonymity in 1950 also discredited Fr. Cefai for skimming money off the top of Maltese donations to the Church. In particular, this anonymous writer claimed that Cefai charged $\$ 25$ for the services of a wedding when the

69 "Petition to Remove Fr. Cefai," February 10, 1946, St. Paul Parish, 1-4 Correspondence 1941-1958, Archdiocese of Detroit Archives.

${ }^{70}$ Michael Cefai, "Letter to Auxiliary Bishop and Chancellor of Detroit, the Most Reverend John A. Donovan," January 3, 1958, St. Paul Parish, 1-4 Correspondence 1941-1958, Archdiocese of Detroit Archives, 3-4.

${ }^{71}$. Scibberras continued his argument in terms of money changing by saying, "The latest joke we heard from Mgr. Hickey was when a petition had been presented him by a group of four Maltese individuals in order to correct some abuses committed by this so called leader of the Maltese but the answer to the surprise of these four individuals communicated to them through a telephone call from Mgr. Hickey was to the effect that this so called leader of the Maltese Colony is 'turning in good annual reports - Finances.' We never knew that we are still living in the days of Judas and the money changers whom the Lord has so bitterly denounced and chased them away from the Temple." Emanuel Scibberras, "Letter to the Archbishop of Detroit, Edward Cardinal Mooney," December 20, 1947, St. Paul Parish, 1-4 Correspondence 1941-1958, Archdiocese of Detroit Archives, 1. 
Archdiocese had set the price at $\$ 15$. The writer charged that this occurred because “overcharging is the pastor's last resort at the St. Paul's Maltese Church in order to have the church open all week because there is hardly left a congregation and besides it takes plenty of money to support his father, mother, sister and aunt although they are all on the payroll of the church and since they are all living in the rectory."72 These criticisms, though harsh, were only one half of the story. Fr. Cefai still had many in the community who supported him as another anonymous letter suggested. ${ }^{73}$ Perhaps Joe Mamo succinctly summed up Fr. Cefai's role in the community, as a "lighting rod" that the community could either criticize and rally around. Either way, he became the focal point of community tensions in the in the postwar years. ${ }^{74}$

Beyond criticism, many took to inviting priests from Malta to come into the community and preach among them. Maltese priests visited Detroit as part of the missionary Society of St. Paul from Australia, some with the intention of staying in Detroit in the 1950s. This action

${ }^{72}$ The letter continued, "with the coming of the Lord into this world, the Sanhedrin and its Judges had been destroyed two thousand years ago, but with priests such as the parish priest of St. Paul's Maltese Church, I think that the Sanhedrin is being re-enacted by exploiting the faithful and subdue them to his will by going over your authority in following the ethical rules. Hypocrites, parasites and whitewashed sepulchers filthy from inside have always been abhorred by the Lord." Veritas, "Letter to the Archbishop of Detroit, Edward Cardinal Mooney," May 24, 1950, St. Paul Parish, 1-4 Correspondence 1941-1958, Archdiocese of Detroit Archives, 1.

${ }^{73}$ A poorly written letter railed against a visiting priest to Most Holy Trinity, Fr. Fsadni, a priest this letter writer suggests was brought in to sow discontent in the community and purposefully to hurt Fr. Cefai. The letter also states that Fr. Fsadni was refused by the Cardinal of Toronto and that Detroit only needs one "beloved pastor and that's all." He further ties Fr. Fsadni to Mussolini, arguing that he came from Italy and not Malta, "He came to Detroit from italy as italia not from Malta for he is not Britishmaltese." Anonymous letter signed "One hundred percent maltse," December 4, 1947, St. Paul Parish Collection, 1-4 Correspondence 1941-1958, Archdiocese of Detroit Archives.

Another letter, this time written from the Chancellor of Detroit to Archbishop Cicognani of Washington D.C. applauds Fr. Cefai, stating that he has "been the object of many malicious attacks and unfounded charges. Almost every visit of a priest from Malta to Detroit precipitates dissension among his fellow countrymen here, and leads to charges against Father Cefai which are biased - if not outright fabrications...I am convinced that Father Cefai is utterly unselfish in his priestly devotion to his people...A priest of less courage and zeal would easily be crushed by the insidious and unfair criticisms to which he is almost constantly subjected by unscrupulous elements among the Maltese colony. Unfortunately, too, the charges so unjustly hurled at him have received sympathic consideration in his native land where an accurate knowledge of conditions as they exist in Detroit is certainly lacking." Chancellor, "Letter to Archbishop A.G. Cicognani, Washington D.C.," March 24, 1953, St. Paul Parish Collection, 1-5 Correspondence 1968-1975, Archdiocese of Detroit Archives.

${ }^{74}$ Joe Mamo interview, November 19, 2012. 
created a huge uproar from Fr. Cefai who consistently argued against the need of further Maltese priests. He rebuffed a Fr. Fsadni from Italy and other Maltese priests from Australia. Fr. Augustine Grech of the Society of St. Paul asserted, "knowing that fifteen thousand Maltese Migrants are settled in Detroit and having only one Maltese priest to take continual care of their needs, we believe that our priests can be put to good use with the present priest in giving their assistance in his hard task of his apostolic work."75 Led by Monsignor Mizzi, the priests began their missions to preach among the Maltese of the city.

But to Fr. Cefai, this Society came to Detroit only to inflame tensions between him and the community. Cefai charged that, they were invited by those "remaining downtown [Maltese,] stubborn and vociferous dissenters." 76 Those dissenters accused Fr. Cefai of stealing $\$ 92,000$ of church funds that were donated to build a new St. Paul's Maltese. Instead, St. Paul's closed and the parish moved to the Church of the Madonna on Detroit's Northwest side. This action, perceived by the downtown Maltese Fr. Cefai referenced, was theft. During Mon. Mizzi's stay in Detroit, he promised, to the dismay of both Fr. Cefai and Archbishop Mooney, to send new Maltese priests to Detroit who would somehow reestablish the downtown parish and build a new church with funds from Rome. Some people latched onto these fanciful dreams and turned the acrimonious split towards violence. Some called Fr. Cefai and "advised [him] to resign peacefully, for, otherwise, beatings, bombs and calumnies would force [him] to resign." 77 Thankfully for all involved, no action ever came from those threats. Neither did any action occur to solidify the grand and dubious claims of reestablishing the downtown parish. Despite all of Fr.

\footnotetext{
${ }^{75}$ Grech was supported by a further letter from the Archbishop of Melbourne written on July 9, 1957 where the Archbishop suggested that the Society of St. Paul "has been of great assistance and is deeply appreciated." Augustine Grech, "Letter to Rev. John A. Donavan, Auxiliary Bishop of Detroit,” December 22, 1957, St. Paul Parish Collection, 1-4 Correspondence 1941-1958, Archdiocese of Detroit Archives.

${ }^{76}$ Michael Cefai, "Letter to Auxiliary Bishop and Chancellor of Detroit, the Most Reverend John A. Donovan,” January 3, 1958, St. Paul Parish, 1-4 Correspondence 1941-1958, Archdiocese of Detroit Archives, 2. 77 Ibid.
} 
Cefai's shortcomings, his short temper, evidence of racism displayed towards his Jewish landlady, and his poorly conceived fundraisers that skirted legal uses of his parish buildings, he did accurately perceive the demographic shift of his Detroit community. ${ }^{78}$

Ultimately, with or without Fr. Cefai, the Maltese religious center was moving away from the heart of Corktown. This shift mirrored the shift in population and hinted at a fragmented community. Prospects of a new Maltese-only parish seemed grim. While St. Paul's had its momentary successes, it failed to be centrally located even in its downtown location, and was filled with petty rivalry. These conflicts caused many Maltese families to attend other churches closer to home with less factionalism. Whether the successes or failures of St. Paul's could be attributed to, Fr. Cefai, the community, or its location, no other church replicated the sense of stability that it offered to the Maltese community. Before leaving St. Paul's Cefai sought to safeguard his flock and their efforts by asking that their funds for a Maltese church follow Cefai ${ }^{79}$ But these building funds not only caused conflict within the community but also got under the nerves of the Archdiocese. The Chancellor bemoaned that his office was filled with "veiled charges, accusations, and rumors concerning the savings fund originally established by

${ }^{78}$ Father Cefai's record at the Archdiocese of Detroit includes several letters throughout his time at the head of the Detroit Maltese community that suggest a man who sought ultimate power and control over the Maltese. Any individual who stepped out of line with his vision of the community, or dared to say anything against him would result in extensively written letters professing his innocence and righteous action to the Archbishop. He was prone to slandering individuals, fighting fire with fire. But he was not innocent of reprimand from the Archbishop and his other superiors who often wrote him in scolding terms, reminding him of the proper uses of his parish buildings, that sales of alcohol for personal profit at church dances was not only immoral but also illegal. He fell into a spat with his Jewish landlady who sought to evict Fr. Cefai and his family, and in an open letter to the entire Maltese community begging them to send money in order to build a new church, he publicly calls the women out for being a "German Jewess." The Chancery caught wind of this plea and after conducting a review of the situation responded to that letter by stating the women was not actually Jewish and "Even if the landlady had been a Jewess, I question the propriety of making that statement in such a public way as in a letter to the parishioners or in a public announcement. If every misdeed which a Catholic performs were to be blamed on his religion, we would feel it was very unfair. We would feel it promoted bigotry, especially in view of the fact that materialism and secularism make it necessary for all religious groups to work together in civic, social and education problems." St. Paul Parish, 1-4 Correspondence 1941-1958, Archdiocese of Detroit Archives, 6 January 1948; 8 September 1947.

${ }^{79}$ Michael Cefai, "Memorandum on St. Pauls" March 11, 1952, St. Paul Parish Collection, 1-4 Correspondence 1941-1958, Archdiocese of Detroit Archives. 
St. Paul's Maltese Parish." 80 He then turned to Fr. Cefai himself, writing, "Seriously, I think I should chide you for your apparent disturbed state of mind over foolish and unscrupulous charges." ${ }^{\prime 1}$ While Cefai never gave up on the idea of a Maltese parish, it lost importance in the community.

St. Paul's parish was ultimately abandoned, sold, and demolished in 1957. In a sad display, where the church sat vacant for several years, the slow death crept unto it. A letter written to the diocese argued that "the captioned premises has now become a hazard to the neighborhood visualize if you will winos, intoxicated entering the church building at will, using the building to sleep off their drunkenness." ${ }^{~}{ }^{2}$ Finally, as part of the urban renewal projects, the Lodge Expressway paved over the historic home of the Maltese. While the Maltese community continued to exist in Detroit through various social clubs, the cohesion of the community unraveled. Social events between friends continued, and many would still visit the downtown club for major events like dances and feasts, but the travel from the suburbs to the city made regular attendance at these events more difficult for many families.

Just as the community in Detroit mirrored its home city's fortunes, so too did the Toronto community. As the city of Toronto boomed after the war, so too did the size and fortunes of the Maltese community. The rapid growth of the Maltese in Toronto came after the Canadian

\footnotetext{
80 "It is extremely difficult for the Cardinal and the members of his staff not to become nettled and impatient because of the veiled charges, accusations, and rumors concering the savings fund originally established by St. Paul's Maltese Parish. Perhaps I should write you a formal letter, giving the assurance that this fund on deposit with the Archdiocese of Detroit is intact and drawing interest at regular intervals. You could then take this letter, have it photographed thousands of times, and then peddle it wherever you wish. Seriously, I think I should chide you for your apparent disturbed state of mind over foolish and unscrupulous charges." The note goes on to claim that Cefai both cries about no Maltese attending Madonna and his need for money there and then also says the Maltese who do attend should have their contributions be added to the St. Paul's contributions and not the Madonna ones. Chancellor, "Letter to Fr. Cefai," July 12, 1958, St. Paul Parish Collection, 1-4 Correspondence 1941-1958, Archdiocese of Detroit Archives.

${ }^{81}$ Ibid.

${ }^{82}$ Joseph Mayes, "Re: St. Paul Maltese Church. Fourth \& Plum St., City.” September 12, 1955, St. Paul Parish Collection, 1-4 Correspondence 1941-1958, Archdiocese of Detroit Archives.
} 
government signed the 1948 deal to allow five-hundred Maltese settlers into the country

followed in quick succession with another two-hundred and fifty. Like before, the admission of Maltese was directed to economic benefits of Canada, though many of them would not last long on their primary work before heading to Toronto. The deal made with the Government of Malta demanded that Maltese immigrants stay and work two years in Canada, and those who did not would be sent back to Malta on the dime of that government. Men like the previously mentioned Charles DeMarco and George Bonavia were two of those who abided by those guidelines. Hundreds of others would, instead of going to Windsor, journey to Toronto ${ }^{83}$ Some, like Antonia Cachia, still faced the headache of bureaucracy. In her case, a simple typo on her papers, confusing her age, led to a delay in her admission to Canada. ${ }^{84}$ Eventually however, the process improved and migration to Canada quickened.

Those Maltese who formed the group of 750 admitted to Canada in a short span, were mostly initially sent to London, Ontario. Before arriving in London, the trip to Canada was described as quite pleasant. Activities were organized for every day, private rooms for all the migrants, and good meals ${ }^{85}$ Once in Canada at Halifax, the migrants were then sent to Fingal Air

83 "You will recall that in October 1947, on a recommendation of the Cabinet Committee on Immigration Policy, the Cabinet approved the admission of 500 Maltese workers to Canada and an Order in Council was passed accordingly. Under this authorization, 458 Maltese workers came to Canada. The Department of Labour reports that all these immigrants are now employed and have proved to be very good workers. Their dependents have since been admitted to Canada." "Memorandum for the Prime Minister: Immigration; admission of 250 Maltese workers," April 27, 1949. Ottawa, Canada. Library and Archives Canada, RG2-B-2 Vol. 166 F. I-50-12.

"The Acting Minister of Mines and Resources now recommends that instead of the 250 Maltese workers proposed for admission last May, 300 Maltese workers be admitted to Canada at the rate of 50 per month commencing April $1^{\text {st }}, 1950$. As you know, 500 Maltese immigrants have been admitted to Canada under authority of Order in Council P.C. 4893 of December $3^{\text {rd }}$, 1947. The majority of these immigrants have now come forward and have been successfully established. If the admission of the additional 300 immigrants is approved, they will be selected by occupations and will be placed in employment by the Department of Labour." "Memorandum for the Prime Minister: Immigration; admission of Maltese workers," September 6, 1949. Ottawa, Canada. Library and Archives Canada, RG2-B-2 Vol. 166 F. I-50-12.

${ }^{84}$ W. J. Bambrick, "Letter from the Department of Mines and Resources to Mr. Salvatore Cachia," June 2, 1947, MU 9783, F1405-89-9, MSR 5108 - Sub 5002, Ontario Provincial Archives, Toronto, Ontario.

${ }^{85}$ Mr. Dominic and Mrs. Lucy Kiomall interview, interviewed by Richard Cumbo, March 10, 1978, Toronto, Ontario, Multicultural Historical Society of Ontario Archives, MAL - 2853 - KIO, Toronto, Ontario. 
Force Base, transformed in the postwar years to an immigration center, where the Canadian government efficiently processed the migrants. ${ }^{86}$ Many of those individuals who came to London in 1949 and 1950 scattered across the region, taking a two-hour trek either east on the 401 to Toronto or west, a similar two-hour trip on the same freeway, to Windsor and Detroit. Fr. Lawrence Bonavia, sent to Toronto for missionary work from Malta in 1949, recalled that many of the people he travelled with had found success stretching across the Great Lakes area. John Bovia moved to Detroit to work as a photographer, where he married and raised a family. George Bonavia, the previously mentioned editor of the Malta News, achieved great success in Windsor before moving to Ottawa to work in immigration services. Carmen Sapino also landed a job working income tax services for the government in Ottawa as well. ${ }^{87}$ These men all represented some of the best-case scenarios for Maltese men in the region, but not all were as lucky.

Many of those who came in the late 40s, were well prepared for life in Canada. Dominic Kiomall was one of those who came over with Fr. Bonavia, but he was ready for his new life. Upon arriving at Union Station, he met his sister Cathy Vassalo who had been living in Canada for years. Kiomall was a language anomaly, having learned not just English at school - which was common for educated individuals in Malta - but also spoke Italian, French, Spanish, and Arabic. With a place to live while he settled in Toronto, a guide to his new city, and fluent language skills, he was at ease. Having come to Canada expressly to work as a mechanic, he brought along his own box of tools for work and immediately set out to find work. Just a day after his arrival he took his mechanic certification test and two days later was working for Robinson Motor in Toronto. Within a few weeks, he found a house in downtown Toronto. With a job and a home, like his counterparts in Detroit, he sent for his family to join him. His wife

\footnotetext{
${ }^{86}$ Fr. Lawrence Bonavia interview, February 17 \& 24, 1978.

${ }^{87}$ Ibid.
} 
Lucy, and their five children ranging in ages from one to eleven, made the journey over just fourth months after Dominic. ${ }^{88}$

Certainly, for some migrants, the transition to life in North America sometimes came down to sheer luck. Cladius Schembri, came to Canada as a straggler with just 25 cents in his possession in the second wave of migration in late 1950. Once processed in London, he moved to Oshawa. Having been there for only two weeks he found a job at an auto factory. To celebrate the occasion, landing a good paying job just in the nick of time, Schembri went to buy a lottery ticket. Just his luck, he won the lottery, and his prize was a brand-new car. In an interview with George Bonavia, he stated, "Il-Kanada hija pajjiz tal-ghageb!' (Canada is a wonderful country!)" 89 Schembri's story and his great luck was uncommon. Many of the men that came to Canada would find it much more difficult to piece together work.

A recession hit Canada in the early 1950s putting many of the newcomer Maltese out of work. This recession further closed North America to migrants from Malta. Already barred from the United States, aspiring Maltese immigrants faced poor job prospects in Canada. The situation became so dire that the Maltese Immigrants Society of Toronto remarked, "We found some of them sleeping on the floors at the Union Station, while others go without a meal for days on end. Most of them receive letters from wives asking for their support, while they themselves are becoming a financial burden on the Canadian people." 90 The recession hit Maltese people hard in all aspects of Canadian life and all across the nation. In 1954, Ford laid off workers in Windsor, hitting the Maltese in that city very hard. ${ }^{91}$ The lay-offs hit both Windsor and Detroit hard

${ }^{88}$ Mr. Dominic and Mrs. Lucy Kiomall interview, March 10, 1978.

${ }^{89}$ Ġorg Bonavia, “Il-Kommunita' Maltija F’Detroit: Ġbir Ghall Knisja Ġdida Maltija,” Malta News, 12 August 1950. Library and Archive Canada, Ottawa, Ontario. George Bonavia Papers

${ }^{90}$ Joseph Buhagiar and Joe Agius, "Letter to the Archbishop," 22 March 1952, Archdiocese of Toronto Archives, James C Cardinal McGuigan Fonds, Ethnic Catholics - Maltese, MG EN08.12

${ }^{91}$ Malta News: Ahbarijiet Ta'Malta, June 1954, p. 2. Library and Archives Canada, Ottawa, Ontario. 
according to the Maltese News. Many of the newest migrants who had recently secured work at Ford were the first to be let go. ${ }^{92}$

Compounding the problem of an economic slowdown was a lack of English skills for many of the migrants who came to Canada. In comparison to their counterparts in Detroit, the Canadian bound migrants often spoke less English. Fr. Bonavia recalled that one of his missions was to teach "a little English" to those migrants before they embarked for Canada on their journey across the Atlantic. ${ }^{93}$ Despite the small education, that a single man could provide for 450 men in just a few weeks, most arrived with little English skills beyond basic survival at first. A 1951 letter from Archbishop of Malta, Michael Gonzi to Archbishop McGuigan stated that "Many of the Maltese migrants to Canada know very little English and they must go to a Maltese priest for confession." 94 While naturally the Archbishop was worried about his flock's spiritual health, the letter raised concern about the quality of Maltese migrants entering Canada.

However, much like their counterparts in Detroit, the new migrants joined a vibrant and assimilating community. The decision of the community elders in the 1920 s to slowly move the community towards the Junction proved to be vitally important to long-term success. With the city growing so quickly, the Junction became integrated into the extensive urban network of transit and employment. In Toronto's west end, the established Maltese had begun to build their own homes, transitioning from renters to owners. The recently married Sapianos moved to the Junction, on St. John Street, during the war in $1940 .{ }^{95}$ Sam Coleiro purchased a plot of land in the Junction in 1944 for $\$ 800$ and immediately began construction on his home. But due to war

${ }^{92}$ Malta News: Ahbarijiet Ta'Malta, May 1954, Library and Archives Canada, Ottawa, Ontario, 2.

${ }^{93}$ Father Lawrence Bonavia interview, February 17 \& 24, 1978.

${ }^{94}$ Archbishop Michael Gonzi, "Letter to Archbishop James McGuigan,” July 10, 1951, Archdiocese of Toronto Archives, James C. Cardinal McGuigan Fonds, Correspondence with Bishops - 1951, MG FA17.81 A-C.

${ }^{95}$ Mr. Lawrence and Mrs. Pauline Sapiano interview, March 6, 1978. 
shortages, items like lumber, bricks, and other building materials were not only more expensive but also harder to find in large quantities. This shortage, combined with Colerios work demands of 13 hours a night, slowed their construction. Much like other self-constructed homes and buildings in North America, the Coleiro's first built a cellar which they could live in while the rest of the home was finished. Eventually, the eight-room house was finished at the cost of $\$ 5,000 \cdot{ }^{96}$ Not only would Maltese build homes in the Junction, but they also expanded to lake front properties north of the city. ${ }^{97}$

As Maltese settled into the Junction they built more than just homes. While Maltese businesses existed in the 1920s, even more businesses operated by Maltese immigrants and catering to Maltese tastes operated in the 1940s and 1950s in Toronto. The Coney Island Restaurant, run by Joe Gauci and Paul Cachia in the Junction on Dundas and Quebec made the claim in their advertisements to be the "only Maltese Restaurant in Toronto specializing in Maltese dishes like Minestra, Stuffat, Pastizzi, and Mqarrun il-Forn." ${ }^{98}$ Not all businesses were successful. Sylvio Cachia opened a meat packing business, manufacturing corned beef, but the business "didn’t work out too successful and then we locked the business up." ${ }^{99}$ Cachia went on to work for the Toronto Star. Outside of food options, there was also Sammut Printing company which specialized in wedding invitations, raised printing, job and commercial printing across Toronto. ${ }^{100}$ These businesses in the Toronto area not only helped provide jobs for new

\footnotetext{
${ }^{96}$ Mr. Salvatore (Sam) \& Mrs. Carmela Colero interview, March 13, 1978. Mr. Colero recalls that the two men, "English people," perhaps native Canadians or maybe English migrants, it was unclear in his story, worked on the home with him. Other than that, he hired no extra help.

${ }^{97}$ Martin Cachi mentions that he has had a family cabin for several years, though does not specific when exactly it was purchased. Seemingly the early 1960s as the interview was conducted in the early 70s. The cottage was on Lake Wilcox. Maria C. Cachia, Martin Cachia, Sylvio Cachia, interviewed by Richard Cumbo, February 10, 1978.

${ }^{98}$ Malta News: Ahbarijiet Ta'Malta, August 1954, Library and Archives Canada, Ottawa, Ontario, 2. ${ }^{99}$ Maria C. Cachia, Martin Cachia, Sylvio Cachia, interviewed by Richard Cumbo, February 10, 1978. ${ }^{100}$ Malta News: Ahbarijiet Ta 'Malta, July 1954, Library and Archives Canada, Ottawa, Ontario, 2.
} 
immigrants and a taste of home, but also raised the profile of Maltese within the greater community.

Not all Maltese built their own businesses, and by the 1940s and 1950s many had spent considerable time in their jobs. While Maltese worked in many different fields, from letter carriers to power companies to teachers, Swift meatpacking and Massey-Harris still commanded a large portion of Maltese employment. ${ }^{101}$ Some of the Maltese who worked at Massey-Harris were, by the 1940s, receiving appreciation for their longevity and hard work. On February 2, 1948, Mr. J. Cachia received a letter from the company congratulating him on completing 25years of work with the company, earning him a place in the "Quarter Century Club." His badge and the By-Laws of the club were to be presented by his "Club Representative, Mr. Wm. Sara of the Press and Forge Department." The club came with some nice privileges as well, most notable was three weeks' worth of vacation time. ${ }^{102}$ Others like Charles Gatt and Victor Camilleri sought careers in the Canadian military. Both Gatt and Camilleri became flight navigators for the Royal Canadian Air Force in the early 1950s. ${ }^{103}$

Similar to Detroit, issues within the Maltese Church arose in Toronto. Fr. Alphonse Cauchi struggled with illness in the postwar years making it difficult to administer to all of the necessary spiritual needs of the Maltese community. The lack of a Maltese priest meant that the Church occasionally closed down, and letters began to flood into the Archbishop's office as Maltese began to feel "deprived of practicing our dear old religious duties...I know that we could have attended any other Catholic Church but still that would not have given us the

${ }^{101}$ Martin Cachia ended up working for the post office as a letter carrier, his brother Emmanuel worked for the power company, and his sister worked as a teacher. Maria C. Cachia, Martin Cachia, Sylvio Cachia, interviewed by Richard Cumbo, February 10, 1978.

${ }^{102}$ A. Merleau, "Letter to Mr. J. Cachia - Quarter Century Club," February 2, 1948. MU 9783, F1405-89-8, MSR sub \#5105, Ontario Provincial Archives, Toronto, Ontario.

${ }^{103}$ Malta News: Ahbarijiet Ta 'Malta, June 1954, Library and Archives Canada, Ottawa, Ontario, 2. 
opportunity of congregating together in one common ceremony." This highlighted the real importance of the Catholic Church to Maltese communities anywhere. It was the opportunity to congregate in common that made the Church so meaningful for the Maltese. Not only did the community have a problem keeping the church open, but other problems included a lack of direction at the church. Community members began to complain that the church had become, "the Sunday night rendezvous of a numerous derelicts of the Junction." ${ }^{104}$ To the Archbishop's credit, he responded to both letters letting them know he is attempting to fix the situation and make sure the Maltese have their own priest. ${ }^{105}$ Unlike in Detroit however, long term solutions would be found.

Prior to Fr. Bonavia, the Maltese religious community was in great disrepair. By 1949, several letters were written to the Archbishop protesting and lamenting the awful conditions of the church they had worked so hard to build. After the death of Fr. Cauchi in 1943, the Maltese community was given a new, non-Maltese priest. But the lack of attention by the new priest created a miserable experience for the community. Beyond the issues of the priest, the still new church was falling apart as was noted in a letter which stated,

The basement church, which we once built by our own hands, is falling to pieces due to the lack of care; one can hardly feel the presence of God in our dirty church: vestments torn and dirty, many times no vigil light before the Blessed Sacrament, no punctuality for the hour of mass, church closed and no mass some days of the week, no holy water, unclean pews and floor. On the last feast of the Immaculate Conception, our working people had to leave the church as the Pastor woke up late for mass. No organization of the parish. ${ }^{106}$

${ }^{104}$ Mr. P. Sapiano, "Letter to the Archbishop," October 12, 1949, Archdiocese of Toronto Archives, St. Paul the Apostle Parish Collection, Parish History - General Correspondence.

${ }^{105}$ Charles Cachia, "Letter to the Archbishop," July 23, 1949, Archdiocese of Toronto Archives, James C. Cardinal McGuigan Fonds, Ethnic Catholics - Maltese, MG EN08.05.

${ }^{106}$ Ibid. 
It was clear that the Archdiocese of Toronto had to take action in order to solve both the physical and spiritual problems facing the community.

The solution to the lack of a Maltese priest at St. Paul's appeared right under the nose of the Archdiocese. Fr. Bonavia arrived in Toronto on a pastoral mission at St. Angus Roman Catholic on Dundas and Grace, after accompanying new migrants to London. However, before he arrived in Toronto for the start of his mission, he had already had contact with the Maltese of the city. On their journey to London, the train from Halifax stopped in Toronto for a short twohour break. It was there that Mrs. Colero literally bumped into the young priest. Picking up her nephew from Union Station, with men chatting to her in Maltese - asking if any wine was available in Canada - Fr. Bonavia sauntered over. It was then that Mrs. Colero recalls picking up the conversation with him, completely unaware of his position. When her nephew called him "padre" she laughed and recalled the recent passing of the Maltese pastor, Fr. Cauchi, in Toronto she said, "I didn't know you were a priest, you know, we need a priest to our church.” Without missing a beat, Fr. Bonavia replied, "Oh yea? You want to kill me like you killed Fr. Cauchi?" She recalled great laughter and a jovial spirit about the new pastor. Unfortunately, Bonavia was not destined yet for the Maltese community. ${ }^{107}$

The news of Bonavia's presence in Canada spread and this drew further letters from the community to the Archbishop. The lack of a Maltese priest for the community was dire, and the thought that a Maltese priest was in Toronto but not preaching at St. Paul's frustrated many. The pressure ramped up on the Archbishop to move Fr. Bonavia from both the community in the city

107 The death of Fr. Cauchi in 1943 was due to cancer. Cauchi worked tirelessly with the Maltese community, even through his illness. Fr. Bonavia termed him the "saintly priest" in a later interview in which he discussed the work of Fr. Cauchi. Mr. Salvatore (Sam) \& Mrs. Carmela Coleiro interview, March 13, 1978. 
and the Archbishop of Malta. ${ }^{108}$ Archbishop McGuigan pulled the proper levers and made certain Fr. Bonavia would be at St. Paul's. His letter in response to Archbishop Gonzi stated that Fr. Bonavia would take "full charge of the Maltese people eon the First Sunday in September 1951." 109 The transfer was approved, and on October 1, 1951, the Maltese Canadian Society of Toronto wrote to thank the Archbishop personally for delivering Fr.Bonavia to St. Paul the Apostle's Church. ${ }^{110}$

Under the guidance of Fr. Bonavia, St. Paul the Apostle's Church experienced a rapid turnaround. His success at St. Paul the Apostle's did not come only through his own ambition but rather through a reliance on key community figures. People like John Zammit who Fr. Bonavia recalled, "lived for the church," and was "the main link between myself and the old Maltese."111 Zammit, joined by Victor Attard, took Fr. Bonavia around to all the homes of Maltese people in Toronto so he could create a census of sorts and understand his community. This initial interaction Fr. Bonavia understood to be critical to his long-term success. He later recalled that it was his objective to visit as many of the families as he could so he could understand their lives and their needs. Not only did the community need him to preach to them, but he claimed, "I needed them, I needed somebody to encourage me because I was a young priest." 112 And encourage him they did. Fr. Bonavia stayed at St. Paul the Apostle's for twenty years, including the construction of a new church in 1955 . The newly constructed church would continue to host the Maltese community and provide a strong central location for future generations.

\footnotetext{
${ }^{108}$ Charles Cachia, "Letter to Archbishop James McGuigan,” July 23, 1949, Archdiocese of Toronto Archives, James C Cardinal McGuigan Fonds, Ethnic Catholics - Maltese, MG EN08.05.

109 Archbishop James McGuigan, "Letter to Archbishop Michael Gonzi," July 18, 1951, Archdiocese of Toronto Archives, James C. Cardinal McGuigan Fonds, Correspondence with Bishops - 1951, MG FA17.81 A-C.

${ }^{110}$ Charles Calleya, "Letter to Archbishop James McGuigan," October 1, 1951, Archdiocese of Toronto Archives, James C Cardinal McGuigan Fonds, Ethnic Catholics - Maltese, MG EN08.08.

${ }^{111}$ Father Lawrence Bonavia interview, February 17 \& 24, 1978.

112 Ibid.
} 
Ultimately, Britishness and skills played less of a factor in the Postwar World for the Maltese. While British negotiations helped open the door to Canada, it did almost nothing for the Maltese hoping to enter the United States. Much of the emigration issues revolved around the growing concept of independence or inclusion. Until the Maltese and British solved their political conundrum, there was great confusion on how to treat the Maltese. The sundering, or potential sundering, of Maltese bonds with Britain made their position less tenable in terms of immigration. Certainly, the access to nearly unlimited immigration pushed many Maltese politicians down the road of integration into the UK. The question of skills sets and skilled labor also became less of an important play. Detroit did not call specifically for skilled labor in the same manner that it did in the 1920s. While skilled craftsmen certainly held major advantages over unskilled labor, it did not provide the immigration pass that it once did. However, once in Detroit those skills continued to open doors to better employment. In Canada, the immigration path improved allowing more Maltese into the country than ever before. Much like their counterparts, the previous generation paved the way for the new generation to gain employment and housing within the community. The fundamental difference however was the Maltese Church, the glue of these ethnic communities. While social clubs and soccer teams continued to provide entertainment for many, it was through church events that the great majority of Maltese came together. With the failure of the Maltese church in Detroit, the bonds of community began to lessen. The opposite occurred in Toronto, with a reinvigoration of the church and a bulwark against suburbanization. 


\section{Epilogue: How Have the Communities Changed?}

The Maltese communities of Detroit and Toronto are intriguing because of their timing, imperial connections, and industrial skills. Their fortunes were directly tied to the fortunes of their host cities; the small number of migrants combined with the political will of the Maltese government to control and direct its migrants to a hospitable destination directly contributed to this focused migration. In the 1960s and early 1970s, as Malta transitioned to an independent government, migration slowed tremendously. As the push of high unemployment subsided and the pull of Detroit became a less lucrative attraction to Maltese migrants, fewer men sought the once great city as a new home. Those who did choose to come did so to join family. Even though Toronto continued to boom, the Maltese migration declined in similar fashion as it had in Detroit. Furthermore, the communities have received few Maltese since the 1980s. Standards of living in Malta have equaled those of western Europe and unemployment stands at $4.1 \%$ in the spring of 2017, third lowest among all EU states. ${ }^{1}$ The most pressing factors for leaving have disappeared. Because of this, the two communities in North America have transitioned from actively supporting new migrants to guardians of heritage.

On September 21, 1964, Malta achieved independence. After a decade of attempts to achieve unification with Britain, both sides agreed upon Malta's independence. The newly won independence brought with it a change to Maltese immigration status, but more importantly it brought a government bent on reinventing its economy through tourism and banking reform. In order to reinvent that economy, it needed to keep the best of Maltese workers in the country,

\footnotetext{
${ }^{1}$ The "Maltese Miracle" economic boom, driven by tourism, banking, and technology jobs, places Malta just behind the Czech Republic and Germany in terms of unemployment across the EU. "Malta retains third lowest unemployment rate in EU," The Malta Independent, May 31, 2017. http://www.independent.com.mt/articles/201705-31/local-news/Malta-retains-third-lowest-unemployment-rate-in-EU-6736174944.
} 
slowing the push for emigration. As Manuel Formosa recalls, construction jobs abounded. He left school in 1960 to work one of those jobs for just a dollar a day. ${ }^{2}$ Eleno Sammut found himself working in several of the new enterprises as well, first at a tile factory before it was shut down and then in 1967 he found work on major hotel construction projects. Although his pay was much worse initially at the construction project, going from $£ 6$ a week to $£ 1.50$ a week, the job offered training and pay raises. Within just two months he had received two raises, making $£ 3.50$ a week. These major projects were products of the Mintoff Labour Government, which sought to retrain Maltese laborers and build a national economy more robust than just the dockyard work. ${ }^{3}$

Even with the growing amount of work in Malta, there were still people who made the move to North America in the 1960s and 1970s. Many of them had finished some or all of their schooling in Malta, worked for a few years and then left to see another part of the world. Manuel Formosa came to Detroit in November 1961 with $\$ 14$ in his pocket. Formosa, the oldest of seven, woke up one day while still in school and was told by his mother that he needed to quit school and start working. He did just that, getting a job with a construction company. After a few years, he started receiving offers from relatives in Australia, and even obtained papers to go there before his father suggested they go to New York City. His father went first and Manuel followed

\footnotetext{
${ }^{2}$ Manuel Formosa, Interview with Author, September 9, 2012, Detroit, Michigan.

${ }^{3}$ Mintoff Economic Works - Sammut discusses how Mintoff came into the General Workers Union meeting and told them all to tighten their belts or there would never be an economic recovery in Malta. Through this, individuals took huge pay cuts and would only receive pay increases once they passed certification tests for skills such as electricians, plumbers, carpenters, and other skills. Part of this investment in workers included a major investment by China in 1972, who built a new dock in Malta, as well as several factories. Sam Flask recalled one of his jobs in Malta was to act as a driver for these new factories which imported Chinese labor. Flask mentioned that each plant had several managers who, despite being Chinese, spoke better Maltese than he did. John Franklin Copper, China's Foreign Aid and Investment Diplomacy, Volume II: History and Practice in Asia, 1950-Present. (Houndsmills, Basingstoke, Hampshire: Palgrave Macmillian, 2016), 98; Salvino Flask interview, interviewed by author, October 23, 2015, Detroit, Michigan.; Eleno Sammut interview, interviewed by author, October 24, 2015, Detroit, Michigan.
} 
on November 21, 1961. While in New York, he was drafted during the Vietnam War. Then he returned to a dead-end job and eventually grew restless. He called his uncle in Detroit who suggested he come to the Motor City. One week after the Detroit riots of 1967, he moved and began work at the Ford Foundry for $\$ 2.50$ an hour. Formosa worked nearly forty years for Ford before retiring, noting that he was "very grateful that I came from a foreign country without education and just made a living with my hands, and I managed to make a good living, raised kids and sent them to college."4

Others were under far less pressure than Formosa to come to North America to make a living. When asked to move to Detroit in 1969 by his father, Joseph Said initially refused. He knew no one in America outside his father and sister, and he wanted to finish his schooling in Malta. In December 1973, done with school and witnessing all of his friends leaving for Australia and Canada, Said left Gozo for Detroit. When asked why he ultimately chose to leave Malta he said, "A lot of people asked me the same question, and I can't answer them. I wanted to try something new and settled in to it. I didn't move here with a gun over my head, it just was a choice. Sometimes it works, sometimes it don't. I've seen other guys that came here and they just couldn't take it." Victor Calleja followed a similar path to Said, joining his brother and sister in Windsor in June of 1974 . He recalled a very easy immigration process, touting the high education standards in Malta in the 1970s and the many Maltese who - by then - spoke several languages well. In his words, "What does the Government of Canada have to lose?"6 Personally, he appeared satisfied. Looking back, he reminisced, "What can I say? I'm not sorry I came, you

\footnotetext{
${ }^{4}$ Manuel Formosa interview, September 9, 2012.

${ }^{5}$ Said also promised his mother that the first $\$ 500$ he earned in Detroit would be saved to buy his ticket back in case he decided he wanted to return. Well, he said the first $\$ 500$ he earned just bought him his first guitar instead. Joseph Said interview, interviewed by author, March 9, 2014, Detroit, Michigan.

${ }^{6}$ Victor Calleja interview, interviewed by author, March 9, 2014, Detroit Michigan.
} 
could say one is sorry I didn’t go back maybe?"7 Calleja did not go back and still resides in Windsor.

By the late 1970s, the migration flow slowed to a trickle each year. Part of the last few "trickles" of migrants to come were men like Salvino Flask and Eleno Sammut, both of whom came in 1978. Sammut, a jack of all trades in terms of work, made the trip to Detroit a year prior to visit his father who had left Malta in the 1960s. The younger Sammut enjoyed his time in Detroit and the next year joined his father, who had bounced around in jobs while in Detroit, spending a short time with Ford before working as a butcher in Corktown and then finally as a janitor at Michigan Central Train Station. Despite instability in his work, the elder Sammut had an eye on acquiring property including properties in Corktown and farmland in Michigan. That left with a career Eleno in Detroit managing properties owned by his family. ${ }^{8}$ Salvino Flask never lived in the city of Detroit but stayed in the suburbs in Livonia. After working at Ford for a few short years, he eventually used his trade as a welder to land a job in a small shop. That small shop quickly blossomed. Because of his technical skills and being on the ground floor of the shops growth, he worked his way to the top echelon of the company. By the 1990s, they had opened two shops in the suburbs and employed more than 200 people. ${ }^{9}$ Both Flask and Sammut played major roles in the Maltese American Community Club in Dearborn and the Maltese American Benevolent Society in Detroit. Flask was an early member of the Dearborn club, helping them find their first building in 1979 and Sammut was elected as President of the Detroit

\footnotetext{
${ }^{7}$ Calleja has a very interesting cross-border life, seeing almost no difference between Detroit and Windsor, 'I've always considered Windsor and Detroit almost one. Homes look the same, roads look the same. It's just about to me... it doesn't make a difference. I can tell you it was a drastic difference, like night to day, between living in Malta and living here" and calling it a "transparent border." He graduated with a degree at St. Clair College in Windsor and another degree at Wayne State University in Detroit. In the 1990s and 2000s he even ran a business in Bloomfield Hills, Michigan until the economic collapse of the 2000s forced him to close his US business and work only from Windsor. Victor Calleja interview, March 9, 2014.

${ }^{8}$ Eleno Sammut interview, October 24, 2015.

${ }^{9}$ Salvino Flask interview, October 23, 2015.
} 
club in the 1980s. These men, and the families they formed in North America, adopted much of the American lifestyle while still retaining their Maltese heritage.

A report in 1975 by the Maltese Canadian Society of Toronto on assimilation trends found the community almost completely indistinguishable from other Canadians. The report identified four major trends as evidence for that assimilation, the first being a high rate of geographic mobility. The Maltese, though still active in the Junction, had moved out to growing Toronto suburbs and cities on the edge of the Greater Toronto Area like Mississauga. The second factor was a high percentage of nuclear families owning their own home and living without extended family members. Third, the contact rate between extended family members was also decreased compared to earlier generations. Finally, the birthrate within the community settled in between two and four children per family. All of these points combined with the selfidentification as "Maltese-Canadian" rather than as Maltese or Canadian. ${ }^{10}$ Though no similar study was conducted in Detroit, evidence suggests that the Maltese in America followed a similar pattern. ${ }^{11}$ Even as the community changed, the social structures left in place by their predecessors continued to provide for the Maltese-Americans and Maltese-Canadians.

Both cities certainly retained their community clubs, their soccer teams, their yearly excursions, and most importantly the Church. All of these institutions and activities intersected and played a significant role both historically and in a transition towards heritage retention instead of assimilation. While the community clubs in Detroit and Dearborn exist today and

\footnotetext{
${ }^{10}$ Godwin Darmanin, “The Effects of City Life on the Maltese Immigrant in Toronto.” MU 9783, F140589-7, 1975, Ontario Provincial Archives, Toronto, Ontario. Maltese polled in the assimilation report claimed: $70 \%$ respond they should be called "Maltese-Canadian," 20\% "Maltese," 10\% "Canadian." Their children was a more unanimous identification; 90\% "Maltese-Canadian," 5\% each for "Maltese" and "Canadian." 10

${ }^{11}$ Rose and John Mifsud had three children in the 1950s; Mary and Charles DeBrincat had four children? In the 1950s and even more recent migrants like Manuel Formosa, Joseph Said, and Victor Calleja all had between two and four children. Though this was a small sample size, those numbers are frequently repeated as part of the integration process.
} 
provide services, the Church continued to provide key cultural functions for the community regardless of its physical location or lack thereof. The Detroit community benefited from an unbroken chain of Maltese priests for the community since the arrival of Father Borg and later Father Cefai. Father William Bonnici became the fourth official chaplain of the Maltese community when he arrived at Most Holy Trinity on January 1, 1973 and succeeded Father Cefai. Father Bonnici served in the role as chaplain for just five years before his replacement, Father Robert Cini, became chaplain in 1978. Father Cini, a member of the Missionary Society of St. Paul, preached in Australia for twenty years before being called to Detroit. ${ }^{12}$

Father Cini's role in carrying on community traditions in Detroit was described by Paul Borg, president of the Maltese American Community Club. Borg said, "Fr. Cini always went beyond his duty as a priest to help us here. He helped our club to keep alive our traditions, particularly our Maltese festi and our traditional Christmas Eve Mass." ${ }^{13}$ Outside of the traditions described by Borg, Fr. Cini also had a role in the community's religious health as well. During his tenure as chaplain he visited the sick, presided over funerals, weddings and baptisms in addition to conducting the celebration of Friday Mass and confessions at the Maltese Club in Dearborn. ${ }^{14}$ Fr. Cini held the role of chaplain for nearly thirty years, before retiring in 2008 and returning to Malta. ${ }^{15}$ Today, the role of community priest is the duty of Father Joseph Mallia who continues to visit the Dearborn and Detroit clubs to serve the community despite being stationed at St. Augustine in Richmond, Michigan some forty miles to the north of Detroit.

\footnotetext{
26, 2008. ${ }^{13}$ Ibid.

${ }^{14}$ Ibid.

${ }^{15}$ Diane Gale Andreassi, Images of America: Maltese in Detroit (Charleston: Arcadia Publishing, 2011),
}

${ }^{12}$ Patrick Cooke, "Maltese Priest and Detroit Church retire together," The Sunday Times (Malta), October 56; 117. 
Meanwhile in Toronto, the arrival of the migrants in the late 1940s opened the door to long term migration from family members in numbers never previously available to Canada. But much like the migration to the United States, by the late 1970s, the level of new migrants significantly dropped. This new growth of migration over a nearly thirty-year period provided opportunity to entrench the Maltese institutions within Toronto's social and religious tapestry. In 1959, Father Bonavia wrote that the growth of St. Paul the Apostle was so rapid that the accommodations for priests was woefully inadequate. Having just paid off their building's mortgage, the community was tasked with raising another $\$ 100,000$ over 24 months to respond to the urgent upgrades. The money was not only raised, but put to great use including the purchasing of perhaps the largest crucifix in the Archdiocese, which was crafted in Gozo and shipped to Toronto. Fr. Bonavia told his congregation, "Your fondest dreams and highest hopes have been surpassed because your Church fulfills the needs of the people, and compares in beauty with any in the Archdiocese."16

The Toronto community hosted Fr. Bonavia for twenty-years before he moved on in his mission, allowing other Maltese priests to step into the void. The Maltese community continued to grow and today there is still a strong Maltese presence at St. Paul the Apostle in what is now termed "Little Malta." Today St. Paul the Apostle is under the territory of the Missionary Sociey of St. Paul and the congregation is led by Fr. Manuel Parnis who continues to offer Maltese language services. ${ }^{17}$ But even "Little Malta" has begun to change. Unlike Detroit though, there is no government renewal programs forcing people out of the neighborhoods. Rather, skyrocketing

\footnotetext{
${ }^{16}$ Fr. Lawrence Bonavia, "Monument to Commemorate the $19^{\text {th }}$ Centenary of the Shipwreck of St. Paul the Apostle in Malta: 60 A.D. - 1960 A.D.” Booklet. MU 9783, Ontario Provincial Archives, Toronto, Ontario.

${ }^{17}$ Fr. Manuel Parnis, a native Maltese, was only recently stationed at St. Paul the Apostle, arriving in November of 2016. Fr. Parnis had spent several years in Pakistan and then Peru before finally being sent to preach to a Maltese congregation.
} 
home prices in Toronto's red-hot real estate market, combined with an aging population looking to downsize homes, has enabled Maltese-Canadians to cash on the price of their homes. Joe and Mary Scerri's story was carried in the National Post in 2015. Having bought their dream home in 1963 at a sum of $\$ 17,000$ the now retired couple, looking for a one story home due to a decrease in mobility, sold their home for $\$ 870,000$ in August of $2015 .{ }^{18}$ The Scerris are not alone, single family homes in the older parts of Toronto averaged around $\$ 1$ million in 2015, giving plenty of incentive to sell. ${ }^{19}$

\section{Conclusion}

This study has aimed to show the enormous role diplomacy had, and continues to have, on immigration policy. Not only does diplomacy bend or in some cases even drive immigration policy but it also creates classes of immigrants that are either socially acceptable or unacceptable based originally on diplomatic pressures. The Maltese who came to Detroit in 1919 and 1920 did so initially because of their own skills. When doors closed to immigrants in 1921, it was the power of diplomacy and their British connection that slowly reversed the decision to keep Maltese out of the country. Once more in the 1950s the Maltese were subjected to a small quota of migrants per year permitted to enter the United States, but as British power waned, and as Malta's position within the Empire sat in flux in the 1950s, diplomacy offered no relief. The diplomatic story was also highlighted in the Canadian migration experience. The diplomatic tussles and intra-imperial infighting in part due to a shifting empire in the $20^{\text {th }}$ century became visible in exploring the Maltese migration experience to Canada. Again, not only did these diplomatic forays shape how individuals could enter Canada, but it also shaped how Canadians

\footnotetext{
18 Joe O'Connor, “Joe and Mary lived in Toronto's Junction neighborhood for 50-plus years. Here's why they're leaving," National Post: Toronto, August 21, 2015. http://nationalpost.com/news/toronto/joe-and-marylived-in-torontos-junction-neighbourhood-for-50-plus-years/wcm/09555f41-51eb-47f6-97b8-d42571d48571 19 Ibid.
} 
saw these migrants. For the Maltese, using the cloak of Britishness was one way they could begin to achieve parity with native-born Canadians.

While historians have begun to tackle the intersection of foreign policy and immigration policy, there is much to learn from the Maltese case about how we might approach this type of history in the future. This work attempted to show the necessity of viewing migration and foreign policy through a truly transnational and comparative lens. By doing so we gain a greater insight into the nuances of the immigration experience. Maltese migrants, and millions of other migrants, were not affected simply by the policies of their intending nations but equally by those nations which they left. For thousands of migrants in the $20^{\text {th }}$ Century like the Maltese who were British subjects, that meant several layers of government from the domestic, to the imperial, and eventually the arrival nation. How Maltese politicians interacted with their British counterparts, and Malta's constantly evolving status within the empire, mattered just as much as any interaction between British and American or British and Canadian officials. By understanding these roles in the immigration story, we begin to realize that immigration policy was not always black and white, but rather that significant areas of the law remained a gray area open to manipulation and tweaking.

Politics and diplomacy played a major role on several occasions in terms of Maltese migration and opening doors to regions of the world that were otherwise barred. While this work exposed how importantly immigration factored into foreign policy decisions involving Malta, it also aimed to show how those policies were intertwined with the lives and skills of people who drove migration on the ground. By examining this phenomenon through the shrouds of diplomacy we begin to understand how people attempted to box in these "in-between" peoples in almost every sense of the word. Politically they were European, but colonial; racially they were 
Southern European Catholics, Arab speaking, but ultimately British to a degree; and socially many were skilled laborers who spoke English, but not all. While some of these overarching issues factored into the lives of people on the ground directly, most of it only influenced them in an indirect way.

Socially, this story shows us that immigrant populations strove not for assimilation even if that was the term many expressed vocally - but for a kind of cohabitation. Though millions of immigrants sought the same outcome, the Maltese case appears unique. Unlike the Italians, Poles, Germans, or Irish who could boast robust communities in nearly every city of the nation, the miniscule size of these communities might have forced them to quickly assimilate and lose their cultural bearings. However, in both Detroit and Toronto they clung tightly to their cultural identifiers, small Maltese grocery shops, benevolent societies, community clubs, soccer teams, and most importantly the Catholic Church. They did this however while expressing their successes at becoming "good" Americans and Canadian. By securing good employment, buying their homes, - and in many cases buying second homes "up north" in the lake country - and serving in the armed forces during times of war, the Maltese embraced their new national identities. In studying the Maltese past, this does not come as a surprise. The "Britishers in Two Worlds" had developed their own Maltese culture that was accustomed to accommodating imperial forces. This history of a dual culture provided these migrants the room to become both good Americans or Canadians without shedding their own Maltese identity.

The Maltese ability to walk in multiple worlds and its relatively small size enabled them to thrive in both the United States and Canada as a community. Though they faced hardships and different challenges in crafting a transnational identity, both communities pursued their new citizenship with vigor while retaining their Maltese heritage. Friction certainly existed about 
what that ultimately could look like. In the views of people like Fr. Cefai the Maltese community would remain isolated from American life to preserve their ethnic "purity," but still take part in their new economic world. Generally, the long-term success of the communities was not Fr. Cefai's dream, as Maltese integrated into their host societies. But at a minimum, community clubs, soccer teams, and the survival of the Maltese parishes speak to their ability to balance their two citizenships. To many of those who ventured to North America, the United States and Canada represented similar opportunities and similar locations near to family. Even if one nation was closed, the other would be close enough to be near relatives and friends and offer similar futures. For the early migrants, it was that ability to be both British subjects as well as Maltese individuals that allowed them success. These early migrants set the stage for later successes. Over time, that ability to walk in two worlds shifted to a focus on their new homelands - being an American or Canadian as well as Maltese. This dual mentality has continued in the present creating a national identity along with a transnational Maltese identity, crossing the "invisible border" between the United States and Canada to build a pan-Maltese culture.

Ultimately, the Maltese story told in this work is one that complicates the American immigration story and asks that we reconsider not just how immigrants migrated to their new homes, not how they felt as they remade their lives in North America, but asks that we take a completely global view of the migration experience. How international, domestic, and imperial politics impact the act of migration, the process of community building in a new home, and, most importantly, how those outside influences and politics force individuals to reimagine the future of their migrant communities. 


\section{$\underline{\text { Appendix A - Bibliography }}$}

\section{Primary Sources}

\section{Archives}

Archdiocese of Detroit Archives: Detroit, Michigan.

St. Paul Parish Collection.

Archdiocese of Toronto Archives: Toronto, Ontario

Ethnic Catholic Fonds, Series MN EC.

James C. Cardinal McGuigan Fonds.

Maltese Canadian Society of Toronto Collection.

St. Paul the Apostle Parish Collection.

Burton Historical Society Archives, Detroit Public Library: Detroit, Michigan.

Library and Archives Canada: Ottawa, Ontario

Canadian Immigration Since Confederation and the Department of External Affairs,

Government Records, Record Group 25, Bulk 1880-1960

George Bonavia Papers

Maltese-Canadian Society of Toronto, MG28, V11

Richard S. Cumbo Papers, 1967-1987

Edward J Spiteri Papers, 1960s-2004

The Maltese Journal, 1935-1946

W.L. Mackenzie King Papers, Vol 88

National Archives of Malta: Rabat, Malta

Office of the Prime Minister (OPM) Collection

Secretary of State (SofS) Collection

Multicultural History Society of Ontario (MHSO): Toronto, Ontario

MAL-2856; Maltese Oral Histories

Archives of Ontario: Toronto, Ontario

Maltese Canadian Textual Records, F1405-89, MU 9783

Maltese Canadian Textual Records, F1405-89, MU 9784

Staffordshire and Stoke on Trent Archive Service, Staffordshire Record Office: Stafford, England

Diary of Sir Walter Congreve, 1924-1927, D1057/0/5/4

United States National Archives: Washington D.C. and College Park, Maryland

Department of State, Record Group 52, Decimal File 1910-1929

Department of State, Record Group 59, Decimal File 1930-1939 
Canadian Admissions and Border Crossings (St. Albans list)

United States Census 1920, 1930, 1940 (via Ancestry.com)

The National Archives of the UK (TNA): Kew, England

Colonial Office (CO) 883/7/4

$\mathrm{CO} 883 / 7 / 12$

$\mathrm{CO} 883 / 7 / 16$

CO $883 / 8$

CO $883 / 8 / 17$

CO $926 / 34$

CO 926/36

HM Treasury (T) 220/79

$\mathrm{T} 715$

Walter P. Reuther Archives, Wayne State University Library: Detroit, Michigan.

Weston Library - Bodleian Libraries, Oxford University: Oxford, England.

Various Reports on the Department of Emigration 1949-1970, Malta, Department of Emigration

Mackenzie King's report on Immigration to Canada from the Orient and India, 1908, 400.225 r. 1

Records of Sir Harry Luke, MSS British Empire S. 286 Luke, Boxes 1-3

\section{Oral Histories}

Numerous interviews have been conducted by the author over the past five years as part of ongoing projects. These interviews took place in various locations including the State of Michigan and the Province of Ontario and range from immigrants to third generation Maltese individuals. years in the metro-Detroit region ranging from immigrants to third generation Maltese individuals. These individuals are properly recognized in the footnotes throughout the dissertation.

\section{$\underline{\text { Secondary Sources }}$}

\section{Newspapers}

Altesleben, Julie Walker. “'Golden' opera singer performing in Dearborn.” Dearborn Press and Guide, November 16, 2010.

Brand-Williams, Oralandar. "Detroit archdiocese reorganization plan finalized." The Detroit News, February 20, 2012.

Cacciottolo, Mario. "Divorce in Malta: Referendum causes acrimonious split." $B B C$ News Malta, May 27, 2011.

Collier, Paul. "Migration Hurts the Homeland." New York Times, November 29, 2013.

"“Council of Maltese Living Abroad' officially established" The Malta Independent Online, July 22, 2012. http://www.independent.com.mt/news.asp?newsitemid=148076 (accessed September 14, 2012). 
"EU referendum: Nigel Farage tells Leave campaigners to focus on migration," BBC News - EU Referendum, 29 April 2016. http://www.bbc.com/news/uk-politics-eu-referendum36167329 (accessed February 28, 2018).

Finnerty, Deirdre. "Why are the French getting an 'MP for London'?" BBC News United Kingdom, June 2, 2012.

Grigorescu, Alexandra. "Bakery still the hub of Maltese community in Toronto." BlogTO, April 8, 2012. http://www.blogto.com/announcements/2012/04/bakery_still_the_hub_of_malte se_community_in_toronto/ (accessed January 23, 2014).

Hjelmgaard, Kim and Alan Gomez, "America is no longer a 'nation of immigrants', USA Today, 23 February 2018. www.usatoday.com/story/news/world/2018/02/23/america-nolonger-nation-immigrants-uscis-says/366207002/ (accessed February 28, 2018).

Keung, Nicholas. "Rise and decline of Toronto's Maltese community." Toronto Star, November $14,2010$.

Kohn, Joe. "St. Frances Cabrini pastor is named a canon in Malta." The Michigan Catholic, December 21, 2007.

"Maltese Become Riotous: Tear a Union Jack to Pieces and Disfigure Queen Victoria's Statue." New York Times, August 15, 1901.

Martin, Jonathan. "Dean Heller's Party Loyalty Not Enough to Stop a G.O.P. Primary Challenge in Nevada," The New York Times, 8 August 2017. (accessed February 28, 2018).

Montemurri, Patricia. "As churches close, hope, help are lost with them." Detroit Free Press, February 12, 2012.

Schembri, David. "Maltese abroad 'even more Maltese"” The Times (Malta), March 16, 2010. (accessed September 14, 2012).

Warikoo, Niraj. "Detroit's historic churches still thriving, helping city." Detroit Free Press, April 8, 2012.

Vigneron, Archbishop Allen H. "Pastoral Plan for the Archdiocese of Detroit." Archdiocese of Detroit, http://tif.aod.org (accessed March 23, 2012).

\section{Published Works}

Abbott, Carl. Urban America in the Modern Age, 1920 to Present. Arlington Heights, Ill: Harlan Davidson, 1987.

Andreassi, Diane Gale. Images of America: Maltese in Detroit. Charleston: Arcadia Publishing, 2011.

Arnesen, Eric. "Whiteness and the Historians' Imagination," International Labor and Working-Class History. No. 60 (Fall, 2001), p. 3-32.

Attard, Lawrence E. Early Maltese Emigration (1900-1914). Valletta, Malta: Gulf Publications, 1983.

-------. Profiles in Maltese Migration. Marsa, Malta: Publishers Enterprises Group, 2003.

-------. The Great Exodus(1918-1939). Marsa, Malta: Publishers Enterprises Group, 1989.

-------. The Safety Valve - A History of Maltese Emigration from 1946. Marsa, Malta: Publishers Enterprises Group, 1997.

Azzopardi, John and Anthony Pace, eds. San Pawl F'Malta u L-formazzjoni Ta 'identità ta' Nazzjon [St. Paul in Malta and the Shaping of a Nation's Identity]. Sta Venera, Malta: Midsea Books, 2010. 
Baldacchino, Godfrey. "Trade Unions in Malta," European Trade Union Institute Report 110. 540.

Ballou, Maturin M. The Story of Malta. New York: Houghton Press, 1893.

Barkan, Elliot R., Hasia Diner, and Alan M. Kraut, eds. From Arrival to Incorporation: Migrants to the U.S. in a Global Era. New York: New York University Press, 2008.

Belich, James. Replenishing the Earth: The Settler Revolution and the Rise of the Anglo- world, 1783-1939. New York: Oxford University Press, 2009.

Bhalla, Vibha. "Detroit and Windsor as Transnational Spaces: A Case Study of Asian Indian Migrants," Michigan Historical Review Vol 34, No 2 (2008), 99-116.

Bodnar, John. The Transplanted: A History of Immigrants in Urban America. Bloomington: Indiana University Press, 1985.

Bodnar, John, Roger Simon, and Michael P. Weber. Lives of Their Own: Blacks, Italians, and Poles in Pittsburgh, 1900-1960. Urbana: University of Illinois Press, 1983.

Borg, Joseph. "Brief History of the Islands of Malta and Gozo.” Malta Virtual Emigration Museum. http://www.maltamigration.com/about/malta.shtml (accessed January 10, 2013).

Boyle, Kevin. Arc of Justice: A Saga of Race, Civil Rights, and Murder in the Jazz Age. New York: H. Holt, 2004.

Bukowczyk, John. And My Children Did Not Know Me: A History of the Polish Americans. Bloomington: University of Indiana Press, 1987.

-------. Permeable Border: The Great Lakes Basin as transnational region, 1650-1990. Pittsburgh: University of Pittsburgh Press, 2005.

Boswell, David. "What's in a Name? The Social Prestige of Residential Areas in Malta as Perceived by Their Inhabitants." in The Urban Context: Ethnicity, Social Networks and Situational Analysis, edited by Alisdair Rogers and Steven Vortovec, 287-334. Oxford: Berg Publishers, 1995.

Cauchi, Maurice N. Maltese Migrants in Australia. Gozo, Malta: Gozo Press, 1990.

-------. The Maltese Migrant Experience. Gozo, Malta: Gozo Press, 1999.

Daniels, Roger. Guarding the Golden Door: American Immigration Policy and Immigrants since 1882. New York: Hill and Wang, 2004.

Dobie, Edith. Malta's Road to Independence. Norman: University of Oklahoma Press, 1967.

Fergusen, Niall. Empire: How Britain Made the Modern World. New York: Basic Books, 2003.

Frendo, Henry. "Britian's European Mediterranean: Language, Religion and Politics in Lord Strickland's Malta (1927-1930)" History of European Ideas, Vol. 21, No. 1 (1995), 4765.

--------. Europe and Empire: Culture, Politics, and Identity in Malta and the Mediterranean (1912-1946). Sta Venera, Malta: Midsea Books, 2012.

--------. Party Politics in a Fortress Colony: The Maltese Experience. Valletta, Malta: Midsea Books, 2013.

--------. The Origins of Maltese Statehood: A Case Study of Decolonization in the Mediterranean. Valletta, Malta: Publishers Enterprise Group, 1999.

Ganado, Herbert. Rajt Malta Tinbidel (I Saw Malta Change) Volume 1. Malta, 1977.

Gabaccia, Donna. From the Other Side: Women, Gender, and Immigrant Life in the U.S., 18201990. Bloomington: Indiana University Press, 1994.

Gerber, David A. American Immigration: A Very Short Introduction. Oxford: Oxford University Press, 2011. 
Gerstle, Gary. Working-Class Americanism: The Politics of Labor in a Textile City, 19141960. New York: Cambridge University Press, 1989.

Graff, George. The People of Michigan. Lansing: Michigan Department of Education, 1974.

Guglielmo, Thomas A. White on Arrival: Italians, Race, Color, and Power in Chicago, 18901945. New York: Oxford University Press, 2004.

Hahamovitch, Cindy. No Man's Land: Jamaican Guestworkers in America and the Global History of Deportable Labor. Princeton, NJ: Princeton University Press, 2011.

Handlin, Oscar. The Uprooted: The Epic Story of the Great Migrations That Made the American People. Philadelphia: University of Pennsylvania Press, 1951.

Hartigan, John. Racial Situations: Class Predicaments of Whiteness in Detroit. Princeton: University of Princeton Press, 1999.

Higham, John. Strangers in the Land: Patterns of American Nativism, 1860-1925. New Brunswick, NJ: Rutgers University Press, 1955.

Hoerder, Dirk, and Nora Fairies. Migrants and Migrations in Modern North America: CrossBorder Lives, Labor Markets, and Politics. Durham: Duke University Press. 2011.

Jacobson, Matthew Frye. Barbarian Virtues: The United States Encounters Foreign Peoples At Home and Abroad, 1876-1917. New York: Hill and Wang, 2000.

Jacobson, Matthew Frye. Whiteness of a Different Color: European Immigrants and the Alchemy of Race. Cambridge: Harvard University Press, 1998.

Jones, Huw R. "Modern Migration from Malta." Transactions of the Institute of British Geographers, no. 60 (November, 1973).

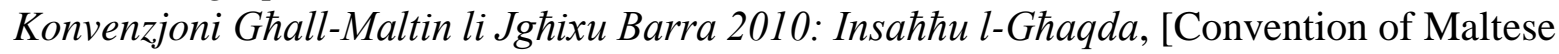
Living Abroad 2010: Strengthening Our Unity] published by the Malta Ministry of Foreign Affairs, 11-16. Valletta, Malta: Best Print Malta, 2010.

Kraut, Alan M. and David A. Gerber, eds. Ethnic Historians and the Mainstream: Shaping America's Immigration Story. New Brunswick, NJ: Rutgers University Press, 2013.

Lee, Erika and Judy Yung. Angel Island: Immigrant Gateway to America. New York: Oxford University Press, 2010.

Lee, Erika. At America's Gates: Chinese Immigration During the Exclusion Era, 1882-1943. Chapel Hill: University of North Carolina Press, 2005.

Lester, Alan and David Lambert. Colonial Lives Across the British Empire: Imperial Careering in the Long Nineteenth Century. Cambridge: Cambridge University Press, 2006.

Louis, William Roger. Ends of British Imperialism: The Scramble for Empire, Suez and Decolonization. London: I.B. Tauris, 2006.

Lubig, Joseph M. Maltese in Michigan. East Lansing: Michigan State University Press, 2011.

Mallette, Karla. European Modernity and the Arab Mediterranean: Toward a new Philology and a Counter Orientalism. Philadelphia: University of Pennsylvania Press, 2010.

Malta. "Migration's Microcosm." International Migration Digest. The Center for Migration Studies of New York, Vol. 1, No. 2 (Autumn, 1964).

Metcalf, Thomas R. Ideologies of the Raj. Cambridge: Cambridge University Press, 1995.

Ngai, Mae. Impossible Subjects: Illegal Aliens and the Making of Modern America. Princeton, NJ: Princeton University Press, 2004.

Nugent, Walter. Crossings: The Great Transatlantic Migrations, 1870-1914. Bloomington: Indiana University Press, 1992.

Oestreicher, Richard Jules. Solidarity and Fragmentation: Working People and Class Consciousness in Detroit, 1875-1900. Urbana: University of Illinois Press, 1989. 
Peck, Gunther. Reinventing Free Labor: Padrones and Immigrant Workers in the North American West, 1880-1930. Cambridge: Cambridge University Press, 2000.

Philips, Kimberley. AlabamaNorth: African-American Migrants, Community, and WorkingClass Activism in Cleveland, 1915-45. Chicago: University of Illinois Press, 1999.

Reimers, David M. Other Immigrants: The Global Origins of the American People. New York: New York University Press, 2005.

Roediger, David. The Wages of Whiteness: Race and the Making of the American Working Class. London: Verso, 1991.

-------. Working Toward Whiteness: How America's Immigrants Became White: The Strange Journey from Ellis Island to the Suburbs. New York: Basic Books, 2005.

Roediger, David and Elizabeth D. Esch. The Production of Difference: Race and Management of Labor in U.S. History. New York: Oxford University Press, 2012.

Sanchez, George J. Becoming Mexican American: Ethnicity, Culture, and Identity in Chicano Los Angeles, 1900-1945. New York: Oxford University Press, 1993.

Sant, Michael A. Ir-Rivoluzzjoni Maltija (The Maltese Revolution). Marsa, Malta: Publishers Enterprises Group, 2004.

Schrag, Peter. Not Fit For Our Society: Immigration and Nativism in America. Berkley: University of California Press, 2010.

Shipway, Martin. Decolonization and its Impact: A Comparative Approach to the End of the Colonial Empires. Malden, MA: Blackwell Publishing, 2008.

Smith, Simon. "Dependence and Independence: Malta and the End of Empire," Journal of Maltese History Vol. 1, No. 1. (2008), 33-47.

Sugrue, Thomas J. The Origins of the Urban Crisis: Race and Inequality in Post-War Detroit. Princeton, NJ: Princeton University Press, 1996.

Tentler, Leslie Woodcock. Seasons of Grace: A History of the Catholic Archdiocese of Detroit. Detroit: Wayne State University Press, 1990.

Thompson, Andrew S. The Empire Strikes Back?: The Impact of Imperialism on Britain from the Mid-Nineteenth Century. Harlow, England: Pearson Longman, 2005.

Thompson, Heather Ann. Whose Detroit?: Politics, Labor, and Race in a Modern American City. Ithaca, NY: Cornell University Press, 2001.

Ueda, Reed. Postwar Immigrant America: A Social History. Boston: Bedford Books of St. Martin's Press, 1994.

Vargas, Zaragosa. Labor Rights Are Civil Rights: Mexican-American Workers in Twentieth Century America. Princeton: Princeton University Press, 2007.

Ward, Stuart ed. British Culture and the End of Empire. Manchester: Manchester University Press, 2001.

Woodford, Frank and Arthur. All our Yesterdays: A brief history of Detroit. Detroit: Wayne State University Press, 1969.

York, Barry. Empire and Race: The Maltese in Australia, 1881-1949. Kensington: New South Wales University Press, 1990.

--------. Maltese Identity in Australia - What Future? National Conference of Maltese Community Councils of Australia, 1993. http://www.maltamigration.com/settlement/demographic/malteseidentity/identity5.shtml? $\mathrm{s}=477422 \mathrm{D5}-5775 \mathrm{C} 087-7 \mathrm{DCA} 22214945-4512$

--------- Maltese in Australia: Wanderings Through the Maltese-Australian Story from Convict Times to the Present. Melbourne: Victoria University of Technology, 1998. 
Zunz, Olivier. The Changing Face of Inequality: Urbanization, Industrial Development, and Immigrants in Detroit, 1880-1920. Chicago: University of Chicago Press, 1982. 